FERNANDA WANDERLEY CORRÊA DE ARAÚJO

\title{
ESTUDO DA REPASSIVAÇÃO DA ARMADURA EM CONCRETOS CARBONATADOS ATRAVÉS DA TÉCNICA DE REALCALINIZAÇÃO QUÍMICA
}

Tese apresentada à Escola Politécnica da Universidade de São Paulo para obtenção de título de Doutor em Engenharia. 
FERNANDA WANDERLEY CORRÊA DE ARAÚJO

\section{ESTUDO DA REPASSIVAÇÃO DA ARMADURA EM CONCRETOS CARBONATADOS ATRAVÉS DA TÉCNICA DE REALCALINIZAÇÃO QUÍMICA}

Tese apresentada à Escola Politécnica da Universidade de São Paulo para obtenção de título de Doutor em Engenharia.

Área de concentração:

Engenharia de Construção Civil e Urbana

Orientador:

Prof. Dr. Paulo Helene 
AUTORIZO A REPRODUÇÃO E DIVULGAÇÃO TOTAL OU PARCIAL DESTE TRABALHO, POR QUALQUER MEIO CONVENCIONAL OU ELETRÔNICO, PARA FINS DE ESTUDO E PESQUISA, DESDE QUE CITADA A FONTE.

Araújo, Fernanda Wanderley Corrêa de Estudo da repassivação da armadura em concretos carbonatados através da técnica de realcalinização química / F.W.C. de Araújo. -- São Paulo, 2009. $217 \mathrm{p}$.

Tese (Doutorado) - Escola Politécnica da Universidade de São Paulo. Departamento de Engenharia de Construção Civil.

1. Estruturas (Recuperação) 2. Eletroquímica 3. Concreto armado I.Universidade de São Paulo. Escola Politécnica. Departamento de Engenharia de Construção Civil II. t. 
Aos meus pais e à minha família,

Agradeço todo amor, investimento e carinho dedicados a mim. 


\section{AGRADECIMENTOS}

Agradeço primeiramente ao Professor Paulo Helene pela confiança, orientação, ensinamentos e chances de aprendizado durante esses quatro anos e meio de convivência.

Agradeço aos Professores Enio Pazini Figueiredo e Eliana Monteiro por terem me aberto as portas para a realização deste projeto de vida, além de terem confiado na minha capacidade.

Agradeço à Escola Politécnica da USP e a todos os seus professores e funcionários pelo suporte, amizade e carinho durante o desenvolvimento deste trabalho.

Agradeço à Engrácia, ao Paulinho e à Fátima pelo carinho e pela ajuda com a parte burocrática do curso.

Agradeço aos amigos reencontrados (Marcelo e Fer Giannotti), e aos amigos conquistados (Luciana, Betinha, Odair, Maurício, Atabyrio, Clebão, Juarez, Clóvis, Flávio e Cris, Leo Grilo e Karlinha, e Leandro e Rejane), não somente pela ajuda durante a realização dos experimentos e análise dos resultados, mas também pelos momentos de alegria e descontração, essenciais para superarmos as dificuldades.

Agradeço à tia Clarinha pelo carinho, abrigo, conselhos e os eventos com o grupo dos culturais e etílicos.

Agradeço ao Antônio Acácio por ter feito essa etapa da minha vida fluir mais tranquilamente, não somente por suas sugestões e mediações, mas principalmente por seu carinho e companheirismo.

Agradeço a Fundação de Amparo à Pesquisa do Estado de São Paulo (FAPESP) pela concessão de recursos de auxílio à pesquisa e pela bolsa de doutorado.

Agradeço ao IPT pelos ensaios realizados, e à ABCP e à Holcim (Brasil) pelos materiais doados para o desenvolvimento desta pesquisa.

Por fim agradeço a todos que direta ou indiretamente contribuíram para a realização deste trabalho. 
Feliz aquele que transfere o que sabe e aprende o que ensina.

(Cora Coralina) 
Escola Politécnica - Universidade de São Paulo - USP - Brasil

\author{
ESTUDO DA REPASSIVAÇÃO DA ARMADURA EM CONCRETOS \\ CARBONATADOS ATRAVÉS DA TÉCNICA DE REALCALINIZAÇÃO \\ QUÍMICA $^{1}$
}

Fernanda Wanderley Corrêa de Araújo

\title{
Resumo
}

Esta pesquisa estudou o método de realcalinização química (RAQ), através da absorção e difusão de soluções alcalinas na superfície do concreto carbonatado. Neste estudo foram utilizadas três espécies químicas para obtenção das soluções alcalinas: carbonato de sódio, hidróxido de potássio, e hidróxido de cálcio. Para avaliar a eficácia desta nova técnica de reabilitação, foram realizadas medidas de profundidade de carbonatação e de realcalinização, medidas eletroquímicas de potencial de corrosão e de espectroscopia de impedância eletroquímica (EIE) para a verificação do estado da armadura, ensaios de imersão, absorção e ascensão capilar em concretos de referência, carbonatados e realcalinizados.

Em razão da falta de conhecimento sobre a eficácia da técnica de realcalinização eletroquímica (RAE) em relação à repassivação da armadura, em paralelo foi realizado o estudo da repassivação das armaduras na RAE. Em relação à durabilidade da técnica, foi avaliada a resistência do concreto recuperado quando submetido a um novo ciclo de carbonatação acelerada, analisando as novas profundidades de carbonatação para cada solução alcalina estudada.

Na repassivação da armadura com a técnica de RAE, a solução de carbonato de sódio proporcionou valores de potencial de corrosão mais eletropositivos do que a solução de $\mathrm{KOH}$, e gráficos de EIE similares aos obtidos com a solução de $\mathrm{KOH}$. Na $\mathrm{RAQ}$, a solução de $\mathrm{KOH}$ foi mais eficiente, sendo os resultados de potencial de corrosão similares aos obtidos com a solução de carbonato de sódio, no entanto, com valores de impedância e ângulo de fase superiores aos obtidos com carbonato de sódio. _A solução de hidróxido de cálcio foi a que obteve os melhores valores de potencial de corrosão, proporcionando às barras valores mais eletropositivos do que antes da carbonatação. No entanto, a RAQ utilizando a solução de hidróxido de cálcio não propiciou a realcalinização do cobrimento do concreto, devendo então ser melhor estudada e, até que sua eficácia seja melhor entendida, sua aplicação deve ser vista com ressalvas.

Ao final dos experimentos foi possível verificar que a RAQ aumentou bastante a durabilidade do cobrimento do concreto quando submetido a um novo ciclo de carbonatação acelerada. Enquanto os corpos-de-prova de referência ao final dos 45 dias de ensaio de carbonatação acelerada foram quase que totalmente carbonatados, os corpos-de-prova realcalinizados com as soluções de carbonato de sódio e hidróxido de potássio não apresentavam qualquer indício de carbonatação.

Palavras-chave: concreto; carbonatação; realcalinização eletroquímica (RAE); realcalinização química (RAQ); repassivação.

\footnotetext{
${ }^{1}$ ARAUJO, F.W.C. Estudo da repassivação das armaduras em concretos carbonatados através da técnica de realcalinização química. 2009. 217p. Tese (Doutorado) - Escola Politécnica, Universidade de São Paulo.
} 


\title{
Polytechnic School - University of São Paulo - USP - Brazil
}

\section{CARBONATED CONCRETE STEEL REPASSIVATION STUDY THROUGH CHEMICAL REALKALISATION TECHNIQUE ${ }^{2}$}

\author{
Fernanda Wanderley Corrêa de Araújo
}

\begin{abstract}
This research studied the method of chemical realkalisation (CRA), through the absorption and diffusion of alkalis in the carbonated concrete surface, as a new technique of rehabilitation. The experimental program was conducted in three set of concrete specimens: reference, carbonated and CRA treated. The CRA method was studied with three types of alkaline solutions: sodium carbonate, potassium hydroxide and calcium hydroxide. To evaluate the effectiveness of CRA treatment was carried out measures of depths of carbonation and realkalisation; electrochemical measurements of potential and electrochemical impedance spectroscopy (EIS) to verify the condition of steel bars; immersion, absorption and capillary tests.
\end{abstract}

Besides these tests, the study of repassivation in corroded steel bars when applied the technique of electrochemical realkalisation (ERA) was also performed in parallel, since their effectiveness is considered unclear in various studies regarding the durability of the technique. The concrete treated with CRA method was submitted to a new accelerated carbonation cycle, and new measurements of carbonation depth were made for each alkaline solution applied.

The repassivates reinforcements with ERA technique showed that the sodium carbonate solution provided corrosion potential values more electropositive than the $\mathrm{KOH}$ solution, and EIS graphics are similar those obtained with the $\mathrm{KOH}$ solution. In CRA technique, the $\mathrm{KOH}$ solution was more efficient, and the results of corrosion potential are similar those obtained with the sodium carbonate solution, however, with the results of impedance and phase angle higher than for sodium carbonate solution. The calcium hydroxide solution showed the best results of corrosion potential, providing bars more electropositive than before carbonation. However, the calcium hydroxide solution not provided the concrete realkalisation, and this alkaline solution should be more studied. Their implementation must be viewed with exceptions until its effectiveness has been proved.

At the end of durability experiments was possible to verify that the CRA greatly increased the concrete durability when subjected to a new accelerated carbonation cycle. After 45 days of testing, the reference concrete specimens were almost totally carbonated. Therefore, the concrete specimens realkalised with sodium carbonate and potassium hydroxide solutions were no carbonation indication.

Keywords: concrete; carbonation; electrochemical realkalisation (ERA); chemical realkalisation (CRA); repassivation.

2 ARAUJO, F.W.C. A study on the carbonated concretes steels repassivation through chemical realkalisation technique. 2009. 217p. PhD Thesis - Polytechnic School - University of São Paulo. 


\section{LISTA DE FIGURAS}

Figura 1.1. Origem das manifestações patológicas com relação às etapas de produção e uso das obras civis de concreto armado (Helene, 2007)..

Figura 1.2. Lei da evolução dos custos das intervenções, Lei de Sitter (1984)................ 2

Figura 2.1. Diagrama de Pourbaix com o sistema $\mathrm{Fe}-\mathrm{H}_{2} \mathrm{O}$ a $25^{\circ} \mathrm{C}$ para um eletrodo padrão de hidrogênio, delimitando os domínios prováveis de corrosão, passivação e

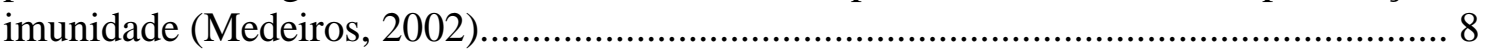

Figura 2.2. Avanço do processo de carbonatação, segundo o CEB/BI 152 (1984)........ 11

Figura 2.3. Teor de umidade dos poros do concreto em função da umidade do ambiente

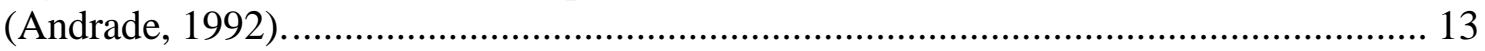

Figura 2.4. Grau de carbonatação em função da umidade relativa do ambiente (Verbeck,

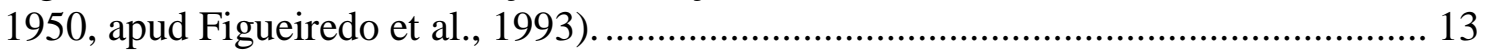

Figura 2.5. Estudo da profundidade carbonatada verso umidade relativa para diferentes classes de concreto realizado por (adaptado de Roy et al., 1999, por Abreu, 2004)...... 14

Figura 2.6. Efeito isolado do percentual de $\mathrm{CO}_{2}$ na profundidade de carbonatação (Pauletti et al., 2007).

Figura 2.7. Influencia do tipo de cimento e sua quantidade por $\mathrm{m} 3$ sobre a profundidade de carbonatação (Ho e Lewis, 1987, apud Figueiredo et al., 1993). 17

Figura 2.8. Coeficiente de carbonatação médios, para cada relação água/aglomerante, para concretos que passaram por cura úmida (Castro, 2003). 18

Figura 2.9. Influencia da relação água/cimento sobre a profundidade de carbonatação (Figueiredo et al., 1993).

Figura 2.10. (a) Valores de potencial da armadura imersa em argamassa por 300 horas. (b) Valores de potencial da armadura imersa por 300 horas em solução de poros formuladas (Poursaee e Hansson, 2007).

Figura 2.11. Potenciais de corrosão obtidos através do GECOR6 para concreto de relação a/c 0,40 (Araujo, 2004).

Figura 3.1. Velocidade da realcalinização química com diferentes soluções alcalinas

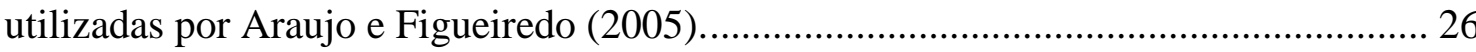

Figura 3.2. Princípio da realcalinização eletroquímica (adaptada de Araujo, 2004)..... 29

Figura 3.3. Esquema da realcalinização química (adaptada de Araujo, 2004)............... 30

Figura 3.4. Realcalinização química por absorção e difusão para relação água/cimento

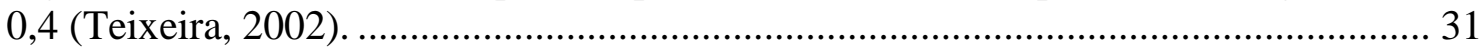

Figura 3.5. Quantidade de argamassa AC I retida após o ensaio de arrancamento em

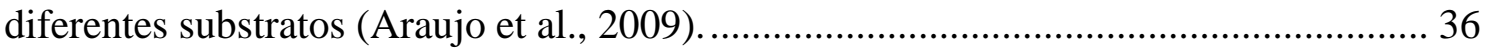

Figura 3.6. Quantidade de argamassa AC II retida após o ensaio de arrancamento em

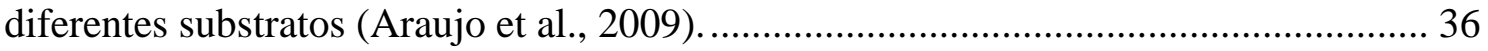

Figura 3.7. Porcentagem de área removida para cada um dos sistemas de pintura

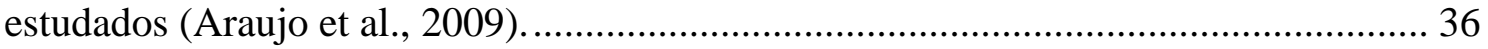


Figura 3.8. Redução da absorção de água em função da RAE (baseado dos dados de

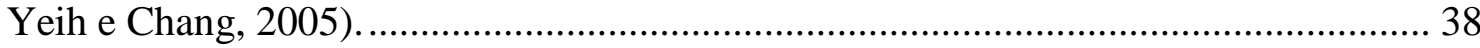

Figura 3.9. Redução da absorção de água em função da densidade de corrente aplicada durante o tratamento de RAE (baseado dos dados de Yeih e Chang, 2005)................. 38

Figura 3.10. (a) Influência da quantidade de corrente aplicada durante a RAE na resistência à compressão. (b) Influência da quantidade de corrente aplicada durante a RAE no módulo de elasticidade (Yeih e Chang, 2005) ................................................ 39

Figura 3.11. Resultados de resistência à compressão em corpos-de-prova de referência, carbonatados e realcalinizados.

Figura 3.12. (a) Influência da quantidade de corrente aplicada durante a RAE no potencial de corrosão. (b) Influência da quantidade de corrente aplicada durante a RAE na taxa de corrosão (Yeih e Chang, 2005).

Figura 3.13. Comparação das barras com baixo (passivo) e alto grau (ativo) de corrosão para diversos tempos de realcalinização e a intensidade de corrosão em solução saturada de $\mathrm{Ca}(\mathrm{OH})_{2}$ (a), e em argamassa alcalina (b) (González et al., 2000). 43

Figura 3.14. Comparação para diversos tempos de imersão em solução saturada de $\mathrm{Ca}(\mathrm{OH})_{2}$ e de velocidade de corrosão de barras com diferentes graus de pré-corrosão, onde: (a)0; (b) 145; (c) 280; e (d) $4300 \mathrm{mg} / \mathrm{dm}^{3}$ de ferro corroído (Miranda et al., 2003).

Figura 4.1. Concreto de relação a/c 0,46. (a) Aparência dos agregados devidamente envolvidos pela argamassa. (b) Abatimento de tronco de cone.

Figura 4.2. Concreto de relação a/c 0,65. (a) Aparência dos agregados devidamente envolvidos pela argamassa. (b) Abatimento de tronco de cone.

Figura 4.3. Concreto de relação a/c 0,93. (a) Aparência dos agregados devidamente envolvidos pela argamassa. (b) Abatimento de tronco de cone. 51

Figura 4.4. Diagrama de dosagem para concretos de abatimento de tronco de cone de

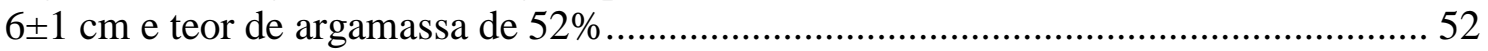

Figura 4.5. Modelo de corpo-de-prova para os ensaios eletroquímicos........................ 53

Figura 4.6. Limpeza das barras com imersão em solução de ácido clorídrico, água destilada e hexametilenotetramina 53

Figura 4.7. As barras após a secagem e armazenadas em um dessecador com sílica gel.

Figura 4.8. Esquema da delimitação da área a ser despassivada. 54

Figura 4.9. (a) Fôrma para moldagem dos corpos-de-prova dos ensaios de medidas eletroquímicas. (b) Detalhe das armaduras cobertas com fita isolante e alinhadas devido às guias. 55

Figura 4.10. Fôrma montada e pronta para a realização da moldagem, com as armaduras revestidas com fita isolante e devidamente alinhadas através das guias. 55

Figura 4.11. (a) Corpos-de-prova cobertos por papel filme para evitar perda de água para o ambiente. (b) Corpos-de-prova depois de 24 horas de moldagem. 55 
Figura 4.12. Caixa plástica com solução de $\mathrm{NaCl}$ saturado (ASTM E104, 2002) para controlar a umidade em $75 \pm 5 \%$, e recipiente de silicato de bário para evitar a carbonatação das amostras no interior das mesmas. 56

Figura 4.13. Corpos-de-prova carbonatados no interior de caixas plásticas para controlar a umidade em $75 \pm 5 \%$ no interior das mesmas. 57

Figura 4.14. Fluxograma dos ensaios eletroquímicos realizados nesta pesquisa. 59

Figura 4.15. Fluxograma dos ensaios físicos realizados nesta pesquisa. 60

Figura 4.16. Gráfico da composição granulométrica do agregado miúdo 62

Figura 4.17. Gráfico da composição granulométrica do agregado graúdo. 62

Figura 4.18. Detalhe da área exposta das barras dos corpos-de-prova prismáticos coberta com graxa condutora para evitar a corrosão das mesmas na câmara de carbonatação. . 64

Figura 4.19. Detalhe dos corpos-de-prova selados com fita adesiva nas faces onde não era desejada a ocorrência da carbonatação acelerada.

Figura 4.20. Câmara de carbonatação acelerada, com capacidade de 1000 litros, empregada para a realização dos ensaios acelerados de carbonatação.

Figura 4.21. (a) Esquema do sistema eletroquímico a ser aplicado na realcalinização. (b) sistema de realcalinização eletroquímica.

Figura 4.22. Esquema do circuito utilizado como fonte de corrente (Monteiro, 2002). 68

Figura 4.23. Chapa de aço inoxidável utilizada como ânodo no tratamento de RAE.... 69

Figura 4.24. Detalhe da colocação do selante e da atuação da frente de carbonatação ou realcalinização no corpo-de-prova. 70

Figura 4.25. Esquema básico do método de determinação do potencial de corrosão da armadura. 71

Figura 4.26. Esquema da obtenção da impedância eletroquímica em um sistema de três eletrodos (Medeiros, 2008) 73

Figura 4.27. Diagrama de Nyquist, com o seu circuito equivalente, para o caso do concreto armado, mostrando o efeito do elemento de Walburg (adaptada de Silva, 2006, e Cascudo, 1991). 75

Figura 4.28. Diagrama de Bode representando a impedância (módulo e ângulo de fase) de um sistema eletroquímico de corrosão em função da freqüência angular (adaptada de

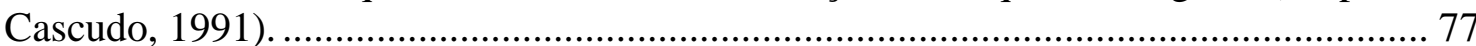

Figura 4.29. Circuito equivalente simples do tipo Randles (Machado, 2004). 77

Figura 4.30. (a) Potenciostato da marca EG\&G Instruments/Modelo 273A. (b) Detalhe da leitura da EIE nos corpos-de-prova de ensaio. 78

Figura 4.31. Recipiente nos qual os corpos-de-prova ficaram imersos para o ensaio, detalhe à direita das escalas para conferência da altura da película de água. 79

Figura 4.32. Corpos-de-prova rompidos transversalmente após a finalização do ensaio de absorção capilar. 80

Figura 5.1. Espectros de impedância de concretos com barras de aço passivada e despassivada (Silva, 2006). 83 
Figura 5.2. Evolução dos espectros de impedância obtidos em concretos com diferentes relações a/c $(0,65$ e 0,80$)$ e tempos de curas $(01$ e 28 dias) antes da carbonatação aos 3,5 meses de idade, com o número da barra a que se referem (Bxxx): (a) Diagrama de Nyquist, (b) e (c) Diagramas de Bode.

Figura 5.3. Corpos-de-prova "irmãos" utilizados nos ensaios eletroquímicos totalmente carbonatados.

Figura 5.4. Resultados de potencial de corrosão (Ecorr) antes de iniciar a carbonatação acelerada (na idade de 3,5 meses) e depois de carbonatado todo o cobrimento da armadura (armaduras despassivadas). Nas duas situações, os corpos-de-prova tinham acabado ser retirado de uma câmara que se encontrava na umidade relativa de $75 \pm 5 \%$.

Figura 5.5. Evolução dos espectros de impedância obtidos em concretos com diferentes relações a/c $(0,65$ e 0,80$)$ e tempos de curas $(01$ e 28 dias) totalmente carbonatados, com o número da barra a que se referem (Bxxx): (a) Diagrama de Nyquist, (b) e (c) Diagramas de Bode. 90

Figura 5.6. Realcalinização eletroquímica dos corpos-de-prova carbonatados. 92

Figura 5.7. Concretos realcalinizados eletroquimicamente em solução de $\mathrm{Na}_{2} \mathrm{CO}_{3}$ na concentração de $1 \mathrm{M}$, que depois de 12 dias de tratamento apresentaram a cristalização de sal na sua superfície: (a) corpo-de-prova de a/c 0,80 e cura de 1 dia; (b) corpos-deprova de a/c 0,65 e cura de 1 dia.

Figura 5.8. Leituras de potencial de corrosão nas barras dos corpos-de-prova realcalinizados eletroquimicamente logo após a finalização do tratamento ainda saturados, e depois de uma semana secos e mantidos em uma caixa com umidade de $75 \pm 5 \%$

Figura 5.9. Leituras de potencial de corrosão nas barras dos corpos-de-prova realcalinizados eletroquimicamente, após 6, 9 e 12 meses da finalização do tratamento.

Figura 5.10. Corpos-de-prova realcalinizados eletroquimicamente: (a) a/c 0,65 com 1 dia de cura; (b) a/c 0,80 com 1 dia de cura; (c) a/c 0,65 com 28 dias de cura; (d) a/c 0,80 com 28 dias de cura.

Figura 5.11. Evolução dos espectros de impedância obtidos nos concretos de relação a/c 0,65 e tempo de cura de 1 dia, nas idades de duas semanas depois de finalizado o tratamento de RAE e de 9 meses, com o número da barra a que se referem (Bxxx): (a) Diagrama de Nyquist, (b) e (c) Diagramas de Bode.

Figura 5.12. Evolução dos espectros de impedância obtidos nos concretos de relação a/c 0,80 e tempo de cura de 1 dia, nas idades de duas semanas depois de finalizado o tratamento de RAE e de 9 meses, com o número da barra a que se referem (Bxxx): (a) Diagrama de Nyquist, (b) e (c) Diagramas de Bode.

Figura 5.13. Evolução dos espectros de impedância obtidos nos concretos de relação a/c 0,65 e 0,80 e tempo de cura de 28 dias, 9 meses depois de finalizado o tratamento de RAE, com o número da barra a que se referem (Bxxx): (a) Diagrama de Nyquist, (b) e (c) Diagramas de Bode. 100

Figura 5.14. Corpos-de-prova durante a realcalinização química por absorção e difusão. 
Figura 5.15. Sal cristalizado nos corpos-de-prova realcalinizado por absorção e difusão em diferentes soluções alcalinas: (a) solução de $1 \mathrm{M}$ de $\mathrm{Na}_{2} \mathrm{CO}_{3}$ e (b) solução de $2,5 \mathrm{M}$ de $\mathrm{KOH}$.

101

Figura 5.16. Deterioração da pasta de cobrimento observada nos corpos-de-prova durante a realcalinização química na solução de $\mathrm{Na}_{2} \mathrm{CO}_{3}$. (a) corpos-de-prova de relação a/c 0,65 com 1 e 28 dias de cura e relação a/c 0,80 com 1 e 28 dias de cura, e apenas o de a/c 0,65 com 28 dias de cura não apresentou degradação. (b) detalhe do destacamento próximo à armadura.

Figura 5.17. Corpos-de-prova realcalinizados sem a aplicação de corrente elétrica: (a) a/c 0,65 (esquerda) e 0,80 (direita) com 1 dia de cura com a solução de $\mathrm{Na}_{2} \mathrm{CO}_{3}$; (b) a/c 0,65 (esquerda) e 0,80 (direita) com 1 dia de cura com a solução de $\mathrm{KOH}$; (c) a/c 0,65 (esquerda) e 0,80 (direita) com 1 dia de cura com a solução de $\mathrm{Ca}(\mathrm{OH})_{2}$; (d) a/c 0,65 com 28 dias de cura com as três soluções estudadas; e a/c 0,80 com 28 dias de cura realcalinizado com (e) solução de $\mathrm{Na}_{2} \mathrm{CO}_{3}$, (f) solução de $\mathrm{KOH}$ e (g) solução de $\mathrm{Ca}(\mathrm{OH})_{2}$. 103

Figura 5.18. Leituras de potencial de corrosão nas barras dos corpos-de-prova realcalinizados quimicamente logo após a finalização do tratamento ainda saturados, e depois de uma semana secos e mantidos em uma caixa com umidade de 75 $\pm 5 \%$....... 104

Figura 5.19. Leituras de potencial de corrosão nas barras dos corpos-de-prova realcalinizados quimicamente, após 1, 3 e 6 meses da finalização do tratamento. ....... 106

Figura 5.20. Deslocamento do semicírculo $(\alpha)$ abaixo do eixo de impedância real (Silva, 2006) 108

Figura 5.21. Evolução dos espectros de impedância obtidos nos concretos de relação a/c 0,65 e tempo de cura de 1 dia, com uma semana e também com 4 meses depois de finalizado o tratamento de RAQ, com o número da barra a que se referem $(\mathrm{Bxxx})$ : (a) Diagrama de Nyquist, (b) e (c) Diagramas de Bode. 109

Figura 5.22. Evolução dos espectros de impedância obtidos nos concretos de relação a/c 0,80 e tempo de cura de 1 dia, com uma semana e também com 4 meses depois de finalizado o tratamento de RAQ, com o número da barra a que se referem (Bxxx): (a) Diagrama de Nyquist, (b) e (c) Diagramas de Bode. 110

Figura 5.23. Evolução dos espectros de impedância obtidos nos concretos de relação a/c 0,65 e tempo de cura de 28 dias, com uma semana e também com 4 meses depois de finalizado o tratamento de RAQ, com o número da barra a que se referem (Bxxx): (a) Diagrama de Nyquist, (b) e (c) Diagramas de Bode. 111

Figura 5.24. Evolução dos espectros de impedância obtidos nos concretos de relação a/c 0,80 e tempo de cura de 28 dias, com uma semana e também com 4 meses depois de finalizado o tratamento de RAQ, com o número da barra a que se referem $(\mathrm{Bxxx})$ : (a) Diagrama de Nyquist, (b) e (c) Diagramas de Bode. 112

Figura 5.25. Correspondência entre o diagrama de Nyquist e o estágio da corrosão no qual a barra se encontra (adaptada de Gu et al., 1997). 113

Figura 5.26. Leituras de potencial de corrosão nas barras dos corpos-de-prova antes da realização da carbonatação acelerada e após 12 meses da finalização do tratamento de RAE. 115

Figura 5.27. Leituras de potencial de corrosão (Ecorr) nas barras dos corpos-de-prova após 12 meses da finalização do tratamento de RAE (período de repassivação), e os 
valores de resistência de polarização $(\mathrm{Rp})$ estimados pela EIE depois de finalizada a carbonatação (período de despassivação). 116

Figura 5.28. Evolução dos espectros de impedância obtidos nos concretos de relação a/c 0,65 e tempo de cura de 1 dia, antes de iniciada a carbonatação, e depois de 9 meses de finalizado o tratamento de RAE, com o número da barra a que se referem ( $\mathrm{Bxxx})$ : (a) Diagrama de Nyquist, (b) e (c) Diagramas de Bode.

Figura 5.29. Evolução dos espectros de impedância obtidos nos concretos de relação a/c 0,80 e tempo de cura de 1 dia, antes de iniciada a carbonatação, e depois de 9 meses de finalizado o tratamento de RAE, com o número da barra a que se referem (Bxxx): (a) Diagrama de Nyquist, (b) e (c) Diagramas de Bode

Figura 5.30. Evolução dos espectros de impedância obtidos nos concretos de relação a/c 0,65 e tempo de cura de 28 dias, antes de iniciada a carbonatação, e depois de 9 meses de finalizado o tratamento de RAE, com o número da barra a que se referem (Bxxx): (a) Diagrama de Nyquist, (b) e (c) Diagramas de Bode. 121

Figura 5.31. Evolução dos espectros de impedância obtidos nos concretos de relação a/c 0,80 e tempo de cura de 28 dias, antes de iniciada a carbonatação, e depois de 9 meses de finalizado o tratamento de RAE, com o número da barra a que se referem (Bxxx): (a) Diagrama de Nyquist, (b) e (c) Diagramas de Bode.

Figura 5.32. Leituras de potencial de corrosão nas barras dos corpos-de-prova antes da realização da carbonatação acelerada e após 6 meses da finalização do tratamento de RAQ.

Figura 5.33. Leituras de potencial de corrosão (Ecorr) nas barras dos corpos-de-prova após 6 meses da finalização do tratamento de RAQ (período de repassivação), e os valores de resistência de polarização $(\mathrm{Rp})$ estimados pela EIE depois de finalizada a carbonatação (período de despassivação). 125

Figura 5.34. Evolução dos espectros de impedância obtidos nos concretos de relação a/c 0,65 e tempo de cura de 1 dia, antes de iniciada a carbonatação, e depois de 4 meses de finalizado o tratamento de RAQ, com o número da barra a que se referem (Bxxx): (a) Diagrama de Nyquist, (b) e (c) Diagramas de Bode. 128

Figura 5.35. Evolução dos espectros de impedância obtidos nos concretos de relação a/c 0,80 e tempo de cura de 1 dia, antes de iniciada a carbonatação, e depois de 4 meses de finalizado o tratamento de RAQ, com o número da barra a que se referem $(\mathrm{Bxxx})$ : (a) Diagrama de Nyquist, (b) e (c) Diagramas de Bode.

Figura 5.36. Evolução dos espectros de impedância obtidos nos concretos de relação a/c 0,65 e tempo de cura de 28 dias, antes de iniciada a carbonatação, e depois de 4 meses de finalizado o tratamento de RAQ, com o número da barra a que se referem (Bxxx): (a) Diagrama de Nyquist, (b) e (c) Diagramas de Bode.

Figura 5.37. Evolução dos espectros de impedância obtidos nos concretos de relação a/c 0,80 e tempo de cura de 28 dias, antes de iniciada a carbonatação, e depois de 4 meses de finalizado o tratamento de RAQ, com o número da barra a que se referem (Bxxx): (a) Diagrama de Nyquist, (b) e (c) Diagramas de Bode. 131

Figura 5.38. Caixas plásticas com solução de NaCl saturado (ASTM E104, 2002) para controlar a umidade em 75 $5 \%$, onde: (a) armazenamento dos corpos-de-prova de referência não carbonatados, (b) armazenamento dos corpos-de-prova de referência carbonatados. 132 
Figura 5.39. Recipiente de hidróxido de bário no interior das caixas plásticas dos corpos-de-prova de referência não carbonatados para evitar a carbonatação das amostras no interior das mesmas.

Figura 5.40. Corpos-de-prova imersos nas soluções alcalinas, e cobertos para não perder água para o ambiente.

Figura 5.41. Corpos-de-prova serrados para medir a profundidade de realcalinização depois de 3 semanas.

Figura 5.42. Profundidade de realcalinização nos corpos-de-prova estudados em cada uma das três soluções alcalinas definidas depois de 3 semanas de tratamento. 134

Figura 5.43. Corpos-de-prova realcalinizados com as soluções de $\mathrm{Na}_{2} \mathrm{CO}_{3}, \mathrm{KOH}$ e $\mathrm{Ca}(\mathrm{OH})_{2}$ fraturados e aspergidos com a solução de fenolftaleína. 134

Figura 5.44. Profundidade de realcalinização nos corpos-de-prova estudados em cada uma das três soluções alcalinas definidas depois de 9 semanas de tratamento. ............ 135

Figura 5.45. Corpo-de-prova serrado e com a sua lateral selada com silicone. ........... 136

Figura 5.46. Corpos-de-prova imersos em película de água de $3 \mathrm{~mm}$........................ 136

Figura 5.47. Ascensão capilar dos corpos-de-prova de referência não carbonatados, referência carbonatados e de referência realcalinizados ionicamente pelas soluções de carbonato de sódio $\left(\mathrm{Na}_{2} \mathrm{CO}_{3}\right)$, hidróxido de potássio $(\mathrm{KOH})$ e cálcio $\left(\mathrm{Ca}(\mathrm{OH})_{2}\right)$. (a) Corpos-de-prova de relação a/c 0,65 com 28 dias de cura e (b) corpos-de-prova de relação a/c 0,80 com 28 dias de cura. 137

Figura 5.48. Gráfico da ascensão capilar dos corpos-de-prova de referência não carbonatados, referência carbonatados e de referência realcalinizados ionicamente pelas soluções de carbonato de sódio $\left(\mathrm{Na}_{2} \mathrm{CO}_{3}\right)$, hidróxido de potássio $(\mathrm{KOH})$ e cálcio $\left(\mathrm{Ca}(\mathrm{OH})_{2}\right)$. (a) Corpos-de-prova de relação a/c 0,65 com 28 dias de cura e (b) corposde-prova de relação a/c 0,80 com 28 dias de cura. 137

Figura 5.49. Absorção capilar dos corpos-de-prova de referência não carbonatados (REF), dos carbonatados (CARB) e dos realcalinizados nas soluções de carbonato de sódio $\left(\mathrm{Na}_{2} \mathrm{CO}_{3}\right)$, hidróxido de potássio $(\mathrm{KOH})$ e cálcio $\left(\mathrm{Ca}(\mathrm{OH})_{2}\right)$. (a) Corpos-de-prova de relação a/c 0,65 com 28 dias de cura e (b) corpos-de-prova de relação a/c 0,80 com 28 dias de cura. 138

Figura 5.50. Recipiente utilizado para a (a) imersão e (b) fervura dos corpos-de-prova. 139

Figura 5.51. (a) Esquema realizado para medir a massa dos corpos-de-prova imersos em água. (b) Fotografia da "balança hidrostática" utilizada no ensaio. 140

Figura 5.52. Absorção por imersão e fervura dos corpos-de-prova de referência não carbonatados (REF), dos carbonatados (CARB) e dos realcalinizados nas soluções de carbonato de sódio $\left(\mathrm{Na}_{2} \mathrm{CO}_{3}\right)$, hidróxido de potássio $(\mathrm{KOH})$ e cálcio $\left(\mathrm{Ca}(\mathrm{OH})_{2}\right)$. (a) Corpos-de-prova de relação a/c 0,65 com 28 dias de cura e (b) corpos-de-prova de relação a/c 0,80 com 28 dias de cura.

Figura 5.53. Índice de vazios obtidos através do ensaio de absorção por imersão e fervura dos corpos-de-prova de referência não carbonatados (REF), dos carbonatados (CARB) e dos realcalinizados nas soluções de carbonato de sódio $\left(\mathrm{Na}_{2} \mathrm{CO}_{3}\right)$, hidróxido de potássio $(\mathrm{KOH})$ e cálcio $\left(\mathrm{Ca}(\mathrm{OH})_{2}\right)$. (a) Corpos-de-prova de relação a/c 0,65 com 28 dias de cura e (b) corpos-de-prova de relação a/c 0,80 com 28 dias de cura. 141 
Figura 5.54. Corpos-de-prova depois de duas semanas na câmara de carbonatação: (a) relação a/c 0,65 com 1 dia de cura, (b) relação a/c 0,65 com 28 dias de cura, (c) relação a/c 0,80 com 1 dia de cura, e (d) relação a/c 0,80 com 28 dias de cura. 142

Figura 5.55. Profundidade de carbonatação dos corpos-de-prova de referência, realcalinizados com carbonato de sódio e hidróxido de potássio, depois de duas semanas......

Figura 5.56. Profundidade de recarbonatação dos corpos-de-prova realcalinizados quimicamente com carbonato de sódio e hidróxido de potássio, depois de 45 dias no interior da câmara de carbonatação. 


\section{LISTA DE TABELAS}

Tabela 2.1. Principais fatores que determinam a velocidade de penetração da frente de carbonatação (Kazmierczak, 1995).

Tabela 2.2. Classificação da agressividade do ambiente conforme a NBR 6118 (ABNT, 2003).

Tabela 2.3. Classificação da agressividade do ambiente sobre as armaduras (Helene, 1995)

Tabela 2.4. Concentrações de gás carbônico utilizadas na carbonatação acelerada em pesquisas nacionais e estrangeiras entre os anos de 2000 e 2007 (complementada de Pauletti et al., 2007).

Tabela 2.5. Classificação da agressividade do ambiente em função de micro e macroclimas de acordo com a NBR 6118 (ABNT, 2003).

Tabela 2.6. Correspondência entre classe de agressividade ambiental e cobrimento nominal para $\Delta \mathrm{c}=10 \mathrm{~mm}$ conforme prescreve a NBR 6118 (ABNT, 2003) ................... 20

Tabela 2.7. Simulação da solução da água dos poros (Poursaee e Hansson, 2007)....... 22

Tabela 3.1. Composição e pH de soluções alcalinas utilizadas por diferentes pesquisadores para proporcionar a formação da película de passivação nas armaduras. 25

Tabela 3.2. Fatores que reduzem a aderência e aumentam a pressão de descolamento da pintura ao substrato realcalinizado eletroquimicamente (Fosroc, sd).

Tabela 4.1. Consumo de cimento dos concretos moldados para a realização dos ensaios da pesquisa.

Tabela 4.2. Resistência à compressão dos concretos moldados nas idade de 1, 3, 7 e 28 dias.

Tabela 4.3. Características de dosagem dos concretos moldados, os quais a quantidade de material seco foi 4,6 e $8(\mathrm{~m}-2, \mathrm{~m}$ e $\mathrm{m}+2)$, com teor de argamassa de $52 \%$ e abatimento de $6 \pm 1 \mathrm{~cm}$.

Tabela 4.4. Traço unitário dos concretos moldados para a realização dos ensaios da pesquisa.

Tabela 4.5. Número de corpos-de-prova de concreto para os ensaios de medidas eletroquímicas (corpo-de-prova prismático 12x10x4,0 cm) ....................................... 58

Tabela 4.6. Número de corpos-de-prova de concreto para o ensaio de absorção capilar e imersão (corpo-de-prova cilíndrico de $5 \times 5 \mathrm{~cm}$ ).

Tabela 4.7. Número de corpos-de-prova de concreto para o ensaio de durabilidade da realcalinização química - RAQ (corpo-de-prova cilíndrico de $5 \times 5 \mathrm{~cm}$ ).......................5 59

Tabela 4.8. Propriedades físicas do cimento CP II E-32.

Tabela 4.9. Propriedades de resistência à compressão, em MPa, do cimento CP II E-32, ensaiado conforme a prescrição da NBR 7215 (ABNT, 1996).

Tabela 4.10. Resultado das propriedades químicas do cimento utilizado..................... 61

Tabela 4.11. Resultado das propriedades físicas do agregado miúdo. .......................... 61

Tabela 4.12. Resultado das propriedades físicas do agregado graúdo. 
Tabela 4.13. Concentrações das soluções utilizadas na realcalinização dos corpos-deprova. 63

Tabela 4.14. Características dos indicadores químicos utilizados nesta para a

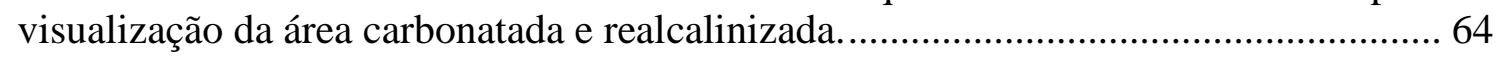

Tabela 4.15. Critérios de avaliação da corrosão através de medidas de potencial de

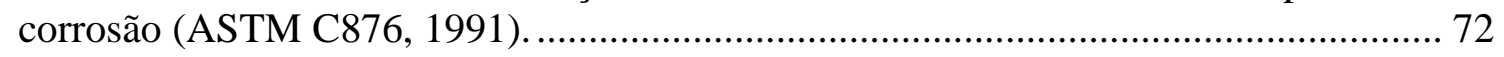

Tabela 4.16. Critérios para avaliar os resultados de velocidade de corrosão (RILEM TC

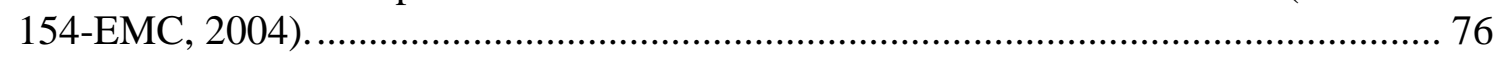

Tabela 5.1. Critérios de avaliação da corrosão através de medidas de potencial de corrosão com eletrodo de cobre-sulfato de cobre (ASTM C876, 1991). 82 


\section{SUMÁRIO}

1. INTRODUÇÃO

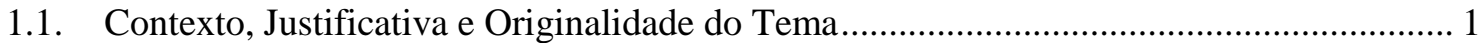

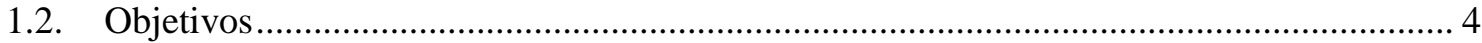

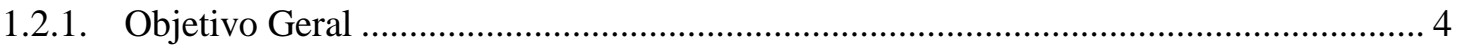

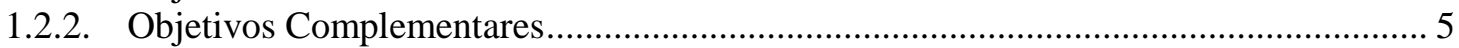

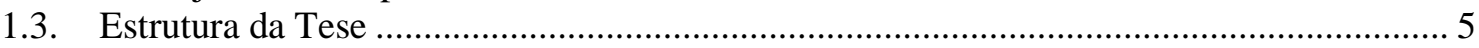

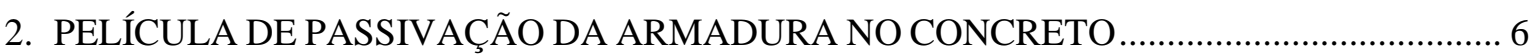

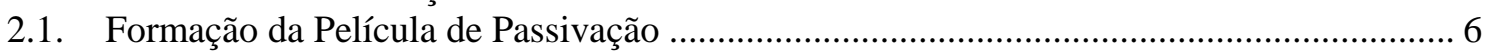

2.2. Perda da Película de Passivação através da Carbonatação ................................................. 9

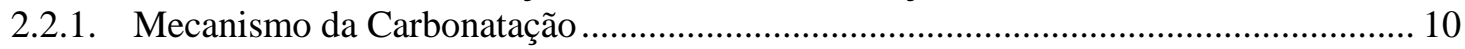

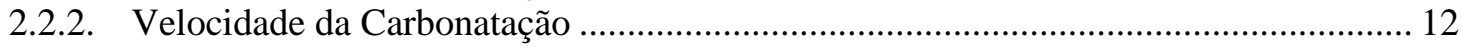

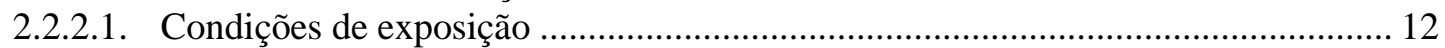

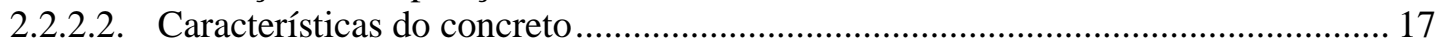

2.2.3. Modelo Clássico para Estimativa da Profundidade de Carbonatação ........................... 20

2.3. Estudo da Película de Proteção da Armadura através de Técnicas Eletroquímicas........... 21

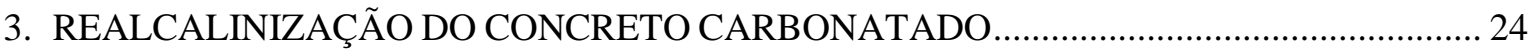

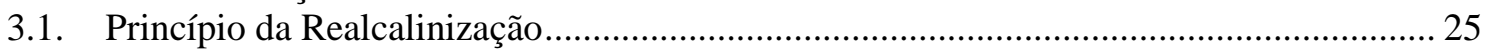

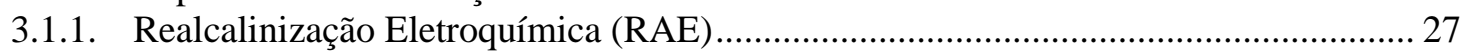

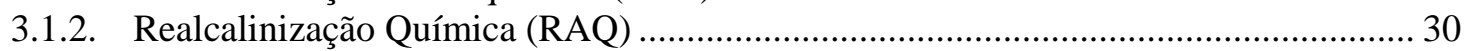

3.2. Efeitos Colaterais Possíveis com o uso da Realcalinização Eletroquímica e Química..... 32

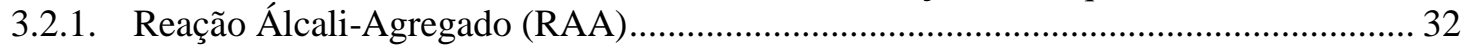

3.2.2. Perda da Aderência de Revestimentos Externos com o Substrato Realcalinizado...... 34

3.2.3. Alteração das Propriedades Químicas e Físicas do Concreto Realcalinizado .............. 37

3.3. Avaliação da Eficiência da Técnica de Realcalinização Eletroquímica ............................ 40

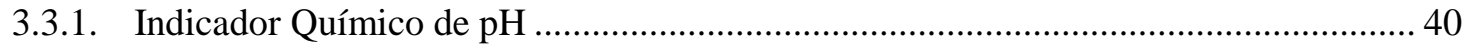

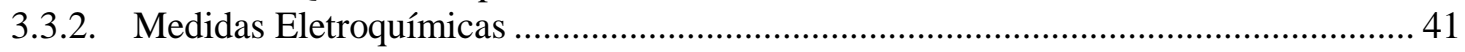

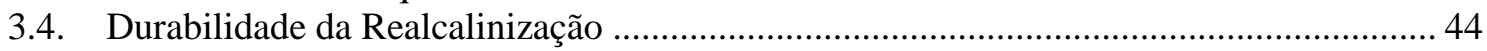

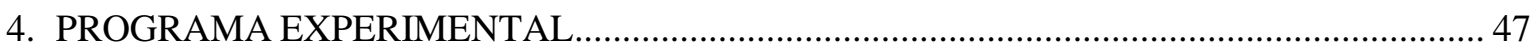

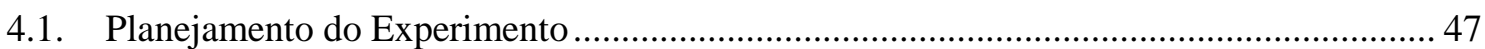

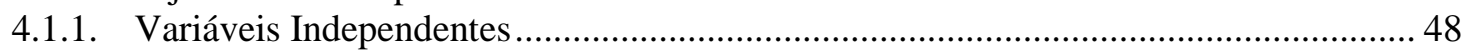

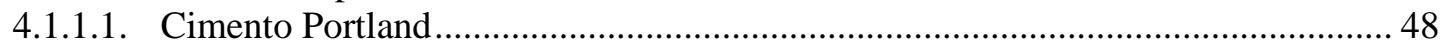

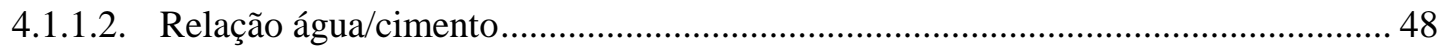

4.1.1.3. Soluções alcalinas empregadas na realcalinização eletroquímica e por absorção

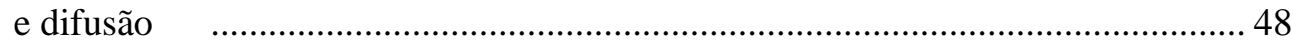

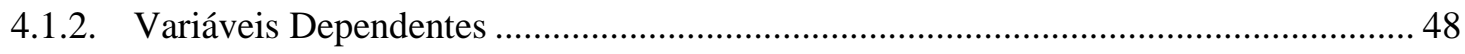

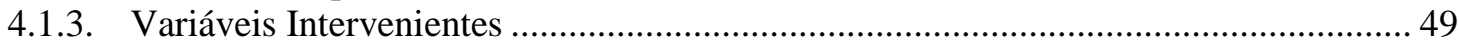

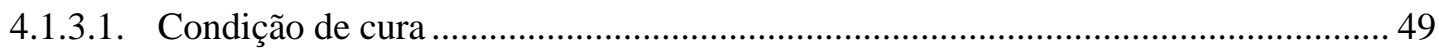

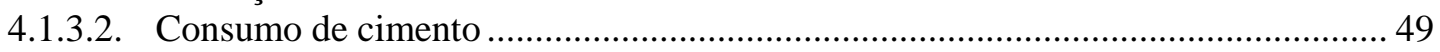

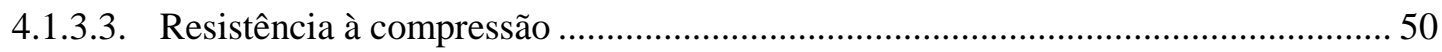

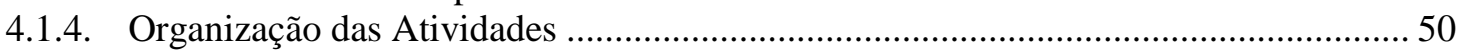

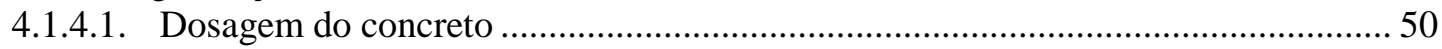

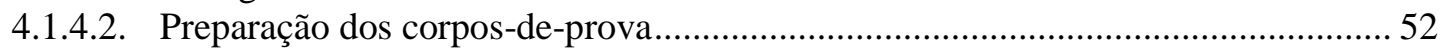

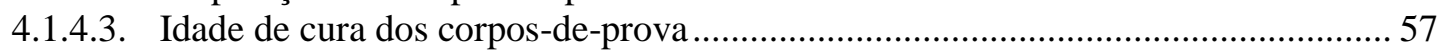

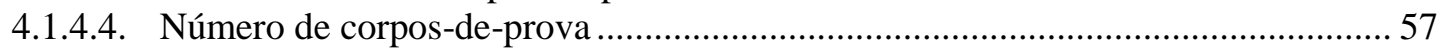

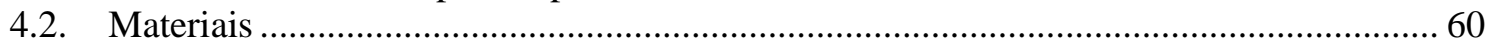

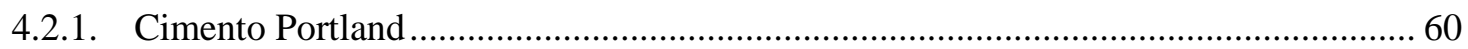

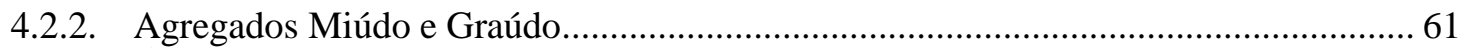

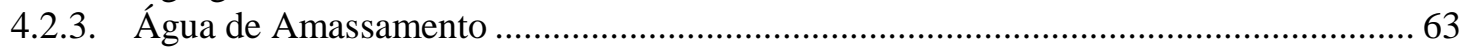

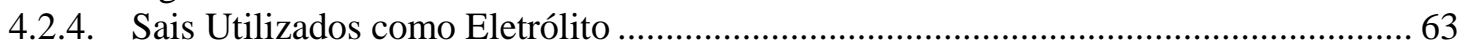

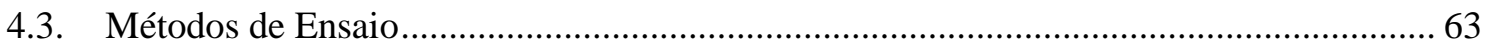


4.3.1. Verificação da Frente de Carbonatação e de Realcalinização ........................................ 63

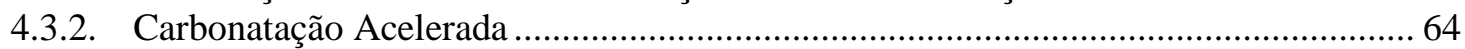

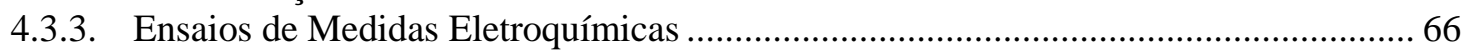

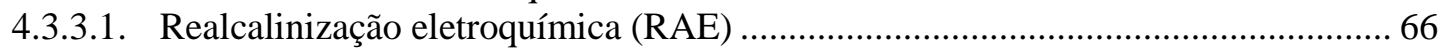

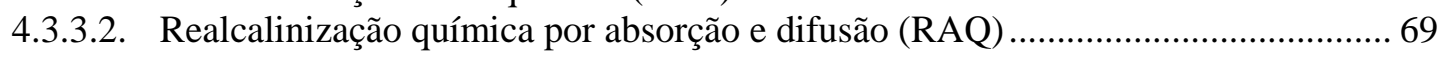

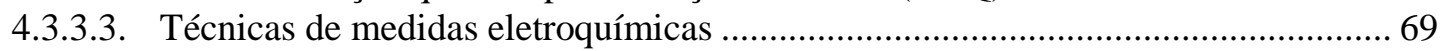

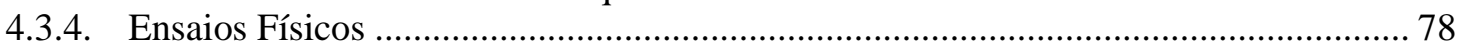

4.3.4.1. Ensaio piloto de ascensão de água por capilaridade ............................................. 79

4.3.4.2. Ensaio de absorção e ascensão capilar da água por capilaridade ............................ 80

4.3.4.3. Ensaio de absorção de água por imersão e fervura................................................ 81

4.3.4.4. Durabilidade da realcalinização química.................................................................. 81

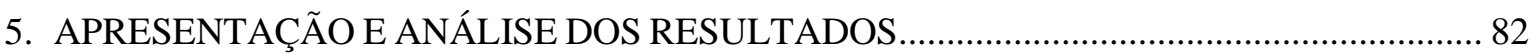

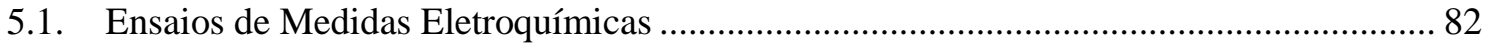

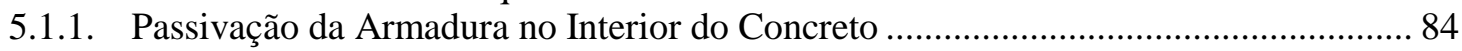

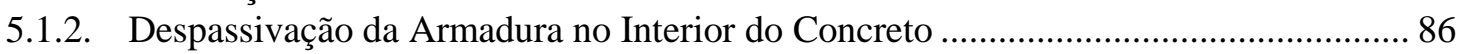

5.1.3. Repassivação da Armadura no Interior do Concreto ................................................... 91

5.1.3.1. Realcalinização eletroquímica (RAE) ……..................................................... 91

5.1.3.2. Realcalinização química por absorção e difusão de soluções alcalinas (RAQ) ... 101

5.1.3.3. Eficácia das realcalinizações na repassivação das armaduras ............................. 113

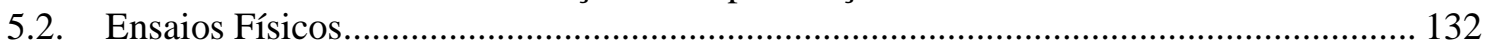

5.2.1. Ensaio de Absorção e Ascensão Capilar da Água por Capilaridade ........................... 135

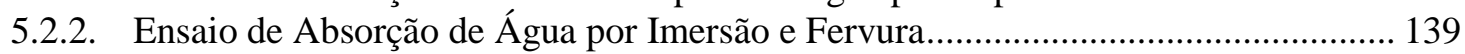

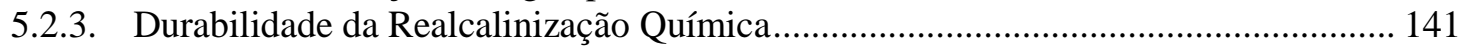

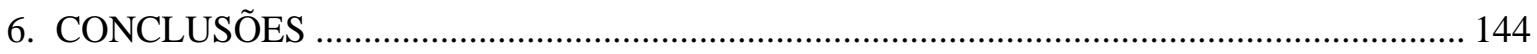

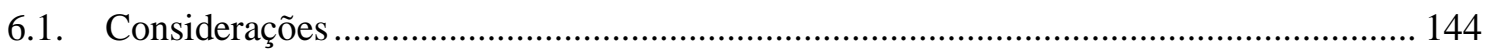

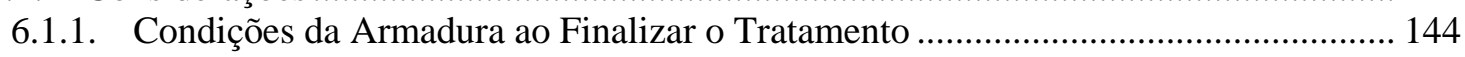

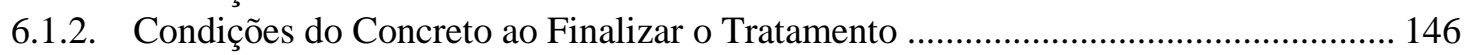

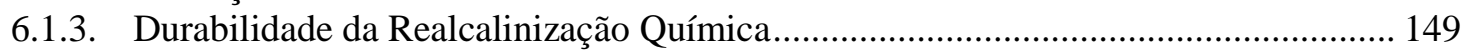

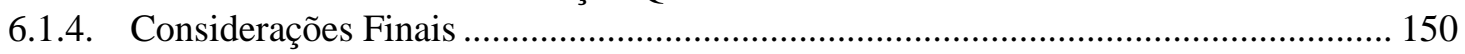

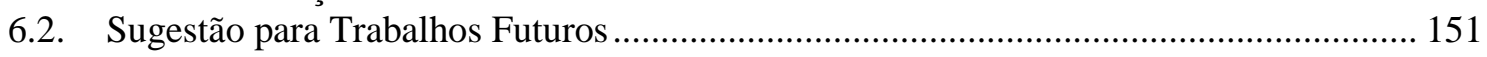

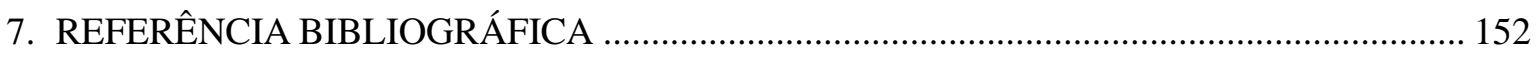

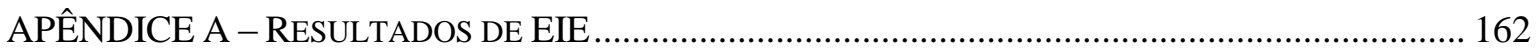




\section{INTRODUÇÃO}

\subsection{ConteXto, Justificativa e ORiginalidade do Tema}

A corrosão de armaduras nas estruturas de concreto armado está consolidada como uma das principais, senão a principal, patologias que afetam a durabilidade das estruturas de concreto armado. Estrutura estas que deveriam apresentar vida útil elevada, mas que por diversas razões se deterioram em prazos inferiores aos previstos. A corrosão de armaduras nas estruturas de concreto armado, como é amplamente difundida, é um fenômeno eletroquímico de grande complexidade e que, comumente, apresenta dificuldades para o diagnóstico e reparo.

De acordo com Helene (2007), os problemas patológicos se manifestam durante a execução ou uso de uma estrutura. Normalmente, os problemas patológicos são notados na etapa de uso, porque se trata de um período de tempo longo, enquanto as fases de planejamento, projeto e execução não passam de 2 anos.

Uma elevada porcentagem das manifestações patológicas tem origem nas etapas de projeto e execução, como é possível observar na Figura 1.1. As falhas de projeto e execução são, em geral, mais graves do que as falhas de qualidade nos materiais ou de mau planejamento execução. É preferível investir mais tempo no detalhamento dos projetos da estrutura do que, por falta de tempo, tomar decisões apressadas e fazer adaptações durante a execução.
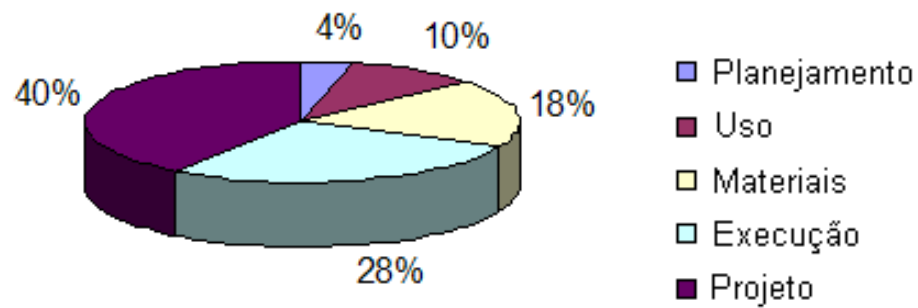

Figura 1.1. Origem das manifestações patológicas com relação às etapas de produção e uso das obras civis de concreto armado (Helene, 2007).

Em geral, os problemas patológicos são evolutivos e tendem a se agravar com o passar do tempo. É possível afirmar que as correções dos problemas provocados pelas manifestações patológicas serão mais duráveis, mais fáceis de executar e muito 
mais econômicas, quanto antes elas forem feitas. A Lei de Sitter (1984), demonstrando esta afirmação, prevê um custo crescente das intervenções de correções, a uma progressão geométrica razão 5, conforme a Figura 1.2.

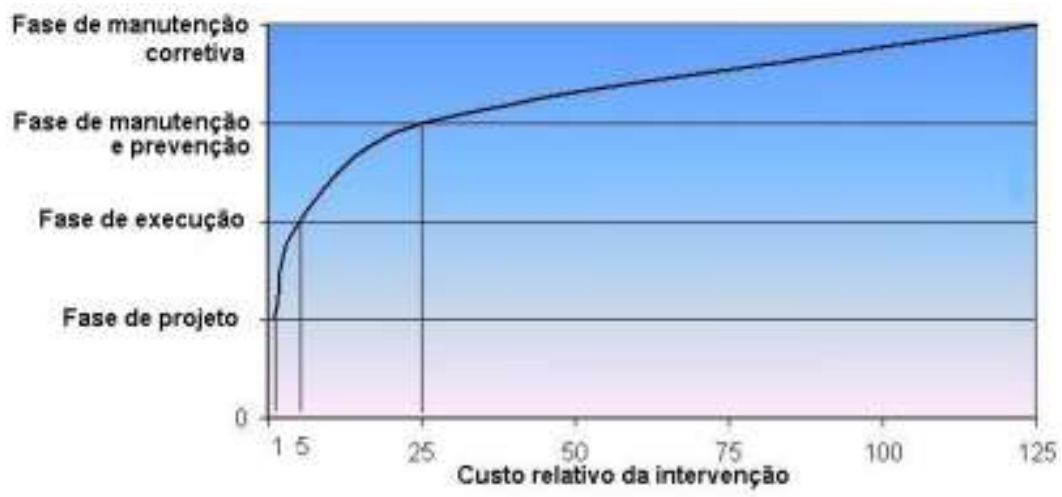

Figura 1.2. Lei da evolução dos custos das intervenções, Lei de Sitter (1984).

Atualmente as técnicas disponíveis para reparar estruturas de concreto atacadas pela corrosão são a de reparo generalizado, reparo localizado, proteção catódica, extração de eletroquímica de íons cloreto, realcalinização eletroquímica e inibidores de corrosão (Pazini et al, 1998).

No estado atual do conhecimento, a realcalinização eletroquímica (RAE) é uma das poucas técnicas que possibilita a reabilitação de forma não destrutiva de estruturas de concreto armado acometidas da corrosão. A técnica de RAE proporciona a ampliação da vida útil das estruturas de concreto armado com o controle da corrosão e o restabelecimento da alcalinidade do concreto, além de promover a repassivação das armaduras. Ainda ressaltando as vantagens da RAE, Mietz (1998) afirma que o método é o mais efetivo para interromper e prevenir a corrosão provocada pela carbonatação e repassivar a armadura, e assim evitar o alto custo de reparos tradicionais e eliminar os fatores que causam a carbonatação e a corrosão.

No entanto, a eficácia da RAE e a durabilidade do tratamento dependem da reconstituição da película de passivação ao redor da armadura e do pH final alcançado na fase aquosa dos poros do concreto. Em estudo sobre a durabilidade da RAE, Hondel e Polder (1992) apud Mietz (1998) realizaram um acompanhamento do $\mathrm{pH}$ final alcançado pelas estruturas realcalinizadas eletroquimicamente e verificaram que, imediatamente depois de finalizado o tratamento, o pH encontrado foi próximo de 14. No entanto, depois de três ou quatro meses, verificou-se um decréscimo do valor de $\mathrm{pH}$ encontrado na mesma estrutura analisada inicialmente. Porém, os autores não informam 
para quanto este $\mathrm{pH}$ foi reduzido, e se houve comprometimento com relação à repassivação da armadura.

Kennedy et al. (1995) utilizaram o carbonato de sódio como eletrólito durante a realcalinização eletroquímica, obtendo que o $\mathrm{pH}$ da estrutura carbonatada foi elevado para valores próximos a 11,5, mantendo-se um $\mathrm{pH}$ final estabilizado, em torno de 10,5. Porém, os autores não informam o tempo transcorrido para chegar a este valor de $\mathrm{pH}$, que é um parâmetro importante para análise eficiência da técnica. Portanto, de modo geral, observa-se que ainda existem lacunas no conhecimento da RAE sobre questões importantes, como a durabilidade do tratamento. Outro ponto onde não há um consenso é com relação à verificação da repassivação da armadura utilizando técnicas de medidas eletroquímicas. Autores como González et al. (2000), Yeih e Chang (2005) e Miranda et al. (2003 e 2006) colocam em dúvida se a RAE realmente possibilita a reconstituição da película de passivação.

Não obstante ao fato da RAE apresentar um conhecimento mais estabelecido, recentemente, uma nova técnica de realcalinização vem sendo desenvolvida no Brasil como um tratamento de reabilitação, na qual a principal diferença em relação a RAE é não utilizar corrente elétrica impressa. Este tratamento é denominado de realcalinização química (RAQ). Em estudo realizado por Araujo (2004), ao finalizar a realcalinização química com as soluções alcalinas de carbonato de sódio, hidróxido de potássio e uma mistura de dessas duas primeiras com hidróxido de cálcio, observou-se que o $\mathrm{pH}$ do concreto próximo à armadura apresentou valores em torno de 12,5 após o tratamento. Sá (2006), dando seguimento ao estudo iniciado por Araujo (2004), verificou que após aproximadamente um ano e meio (595 dias), os concretos realcalinizados com as diferentes soluções alcalinas ainda apresentavam-se altamente alcalino próximo à armadura. Porém, neste estudo, o autor não analisa se ocorreu a recarbonatação do cobrimento e, conseqüentemente, a sua profundidade. Assim como observado em estudos com a utilização da RAE (González et al., 2000; Yeih e Chang, 2005 e Miranda et al, 2003 e 2006), a utilização da RAQ com as soluções alcalinas mencionadas anteriormente também não proporcionou medidas satisfatórias de potencial de corrosão que indiquem uma possível repassivação da armadura (Araujo, 2004, e Sá, 2006).

Como justificativa mais ampla deste doutorado está a questão da durabilidade e da deterioração estruturas de concreto armado, que podem resultar em 
conseqüências sérias em relação à aspectos de segurança e também acarretar prejuízos econômicos envolvidos na manutenção e reparo das estruturas de concreto armado.

Especificamente em relação ao tema de estudo deste doutorado, como justificativa tem-se o caráter original da viabilização da RAQ, o intuito de avançar no preenchimento de algumas das lacunas existentes no conhecimento do tema abordado e as vantagens associadas, que podem ser obtidas com o avanço do conhecimento na utilização deste tipo de reabilitação em estruturas de concreto armado. Dentre as lacunas existentes, pode-se citar a ausência de estudos que comprovem a eficiência de um eletrólito na reconstituição da película de passivação e a verificação da durabilidade dos cobrimento realcalinizados quando submetidos a um novo ciclo de carbonatação acelerada.

As vantagens da RAQ em relação às demais estão na simplicidade da técnica, não precisando de mão-de-obra especializada e nem equipamentos sofisticados para medição e controle da corrente elétrica aplicada, como ocorre na RAE. Outras vantagens estão no caráter não destrutivo da técnica, implicando na mínima quantidade de concreto a ser retirada e reparada, e do menor transtorno causado no local de aplicação, permitindo que os mesmos continuem a ser utilizados durante a recuperação.

Desta forma, esta pesquisa propõe como originalidade um estudo de verificação da eficácia tanto da RAE, quanto da RAQ em relação à reconstituição da película de passivação da armadura, através das técnicas eletroquímicas de medida de potencial de corrosão e de espectroscopia de impedância eletroquímica (EIE). Como também, observar a durabilidade das estruturas realcalinizadas através da técnica de RAQ por absorção e difusão com diferentes tipos de soluções alcalinas. Em paralelo a realização de um estudo comparativo do pH concreto realcalinizado após 6 meses, e a verificação da recarbonatação em processo acelerado dos corpos-de-prova de referência e realcalinizados nas diferentes soluções alcalinas.

\subsection{OBJeTIVOS}

\subsubsection{OBJETIVO GERAL}

A pesquisa tem como objetivo geral verificar a repassivação da armadura em concretos carbonatados através da realcalinização química com diferentes tipos de soluções alcalinas. 


\subsubsection{OBJETIVOS COMPLEMENTARES}

Avaliação da durabilidade da realcalinização química em condições de carbonatação aceleradas, e verificação das mudanças físicas da estrutura realcalinizada com os ensaios de absorção capilar e de imersão do concreto.

\subsection{ESTRUTURA DA TESE}

A presente tese apresenta sete capítulos que visam aprofundar o estudo da realcalinização química por absorção e difusão de soluções alcalinas, incrementando os estudos já realizados na área para a sua viabilização.

O Capítulo 2 desta tese tem como objetivo revisar os conceitos gerais da formação e perda da película de passivação ao redor da armadura imersa no concreto.

Para então, no Capítulo 3 introduzir os conceitos de realcalinização e conseqüentemente enfocar a repassivação das armaduras, tanto a eletroquímica (RAE), quanto química por absorção e difusão (RAQ). Apesar da existência de poucos textos sobre a realcalinização química por absorção e difusão, foi possível neste capítulo, através de dissertações desenvolvidas na Universidade Federal de Goiás, orientadas pelo Professor Dr. Enio Pazini Figueiredo, reunir uma boa quantidade de informações a este respeito. Neste capítulo procurou-se relacionar às técnicas de realcalinização aos seus efeitos colaterais e a sua durabilidade nas estruturas, principalmente com relação à RAE, pois, os dados a respeito da RAQ ainda são escassos.

A metodologia, onde foram detalhados os procedimentos experimentais realizados, bem como a forma com que foram definidos, é apresentada no Capítulo 4.

O Capítulo 5 possui o registro dos resultados obtidos com as respectivas análises e considerações. Os resultados apresentados seguiram a seqüência apresentada no Capítulo 4.

No Capítulo 6 foram apresentadas uma síntese dos resultados e as considerações finais relacionadas aos objetivos da tese.

No Capítulo 7 são referenciados todos os trabalhos que serviram como base para esta Tese. 


\section{PELÍCULA DE PASSIVAÇÃo DA ARMADURA NO}

CONCRETO

Neste trabalho será abordada a repassivação das armaduras dentro do concreto através das realcalinizações eletroquímica (RAE) e química (RAQ). Para o entendimento de porque e como a repassivação ocorre, neste Capítulo será explanado primeiramente, de forma clara e objetiva, os princípios eletroquímicos da formação da película de passivação ao redor da armadura. Abordando também a explanação sobre a carbonatação do concreto, um dos principais meios de despassivação da armadura.

\subsection{FormaÇão da Película de Passivação}

A formação da película de passivação está intimamente ligada aos produtos de hidratação formados na pasta de cimento Portland.

De acordo com Mehta e Monteiro (2008), a matriz da pasta de cimento e a zona de transição contêm produtos de hidratação, distribuídos heterogeneamente, com diferentes tipos e quantidades de fases sólidas. Quando o cimento é disperso em água, o sulfato de cálcio e os compostos de cálcio formados a altas temperaturas, durante a fabricação do cimento, tendem a entrar em solução, e a fase líquida torna-se rapidamente saturada com várias espécies iônicas. Como resultado das combinações entre o cálcio, o sulfato, o aluminato e os íons hidroxila, aparecem primeiramente os cristais aciculares de trissulfoaluminato de cálcio hidratado (etringita). Depois de algumas horas aparecem os grandes cristais prismáticos de hidróxido de cálcio (portlandita) e os pequenos cristais fibrilares de silicato de cálcio hidratado (C-S-H). A combinação dos compostos do clínquer finamente moído com a água, geralmente não é totalizada. Assim, ainda ficam restando grãos de clínquer não hidratados (estado anidro) na pasta de cimento endurecida.

E de acordo com Andrade et al. (1995), a solução nos poros do concreto de cimento Portland consiste principalmente de uma solução saturada de $\mathrm{Ca}(\mathrm{OH})_{2}$ (hidróxido de cálcio), a qual fornece uma alcalinidade de $\mathrm{pH}$ elevado, em torno de 12, ao concreto. Estes afirmam ainda, que com o avanço da idade do concreto esta 
alcalinidade pode ser incrementada para valores de $\mathrm{pH}$ superiores a 13 devido à presença de outros hidróxidos como o potássio $(\mathrm{KOH})$ e o sódio $(\mathrm{NaOH})$.

A alta alcalinidade do concreto favorece à formação de uma película delgada de óxido de ferro ao redor da armadura. Esta película, ou filme, é bastante aderente ao aço, invisível e protege a armadura da corrosão, sendo isto consenso e destaque no ACI 222 (ACI, 2001).

Ainda de acordo com ACI 222 (ACI, 2001), a película formada ao redor da armadura não impede a corrosão, pois de acordo com as Equações 2.1 a 2.4 (ACI, 2001) a película apenas reduz a taxa de corrosão a níveis insignificantes, tornando a dissolução do aço desprezível. Com a presença da película, a taxa de corrosão permanece inferior à ordem de $0,1 \mu \mathrm{A} / \mathrm{cm}^{2}$, porém, com seu rompimento, a taxa de corrosão se eleva e pode chegar a uma ordem de magnitude muito superior a citada.

$$
\begin{aligned}
& \mathrm{Fe} \rightarrow 2 \mathrm{e}^{-}+\mathrm{Fe}^{2+} \\
& 2 \mathrm{H}_{2} \mathrm{O}+\mathrm{O}_{2}+4 e^{-} \rightarrow 4(\mathrm{OH})^{-} \\
& \mathrm{Fe}^{2+}+2 \mathrm{OH}^{-} \rightarrow \mathrm{Fe}(\mathrm{OH})_{2} \\
& 2 \mathrm{Fe}(\mathrm{OH})_{2}+\frac{1}{2} \mathrm{O}_{2} \rightarrow 2 \mathrm{FeOOH}+\mathrm{H}_{2} \mathrm{O}
\end{aligned}
$$

Alguns pesquisadores como Nagayama e Cohen (1963) e Kruger e Calvert (1967), ambos citados por Moreno et al. (2004), afirmam que a película de passivação formada através das soluções alcalinas é composta de óxido de ferro $\left(\mathrm{Fe}_{3} \mathrm{O}_{4}\right.$ ou $\gamma$ $\mathrm{Fe}_{2} \mathrm{O}_{3}$ ). No entanto, Smialowska e seus colegas de trabalho (1981 e 1985, apud Moreno et al., 2004), concluíram que a composição do filme de passivação, formado através da solução de hidróxido de cálcio e de sódio, encontrava-se na forma de óxido de ferro hidratado ou oxi-hidroxido de ferro (FeOOH), como descrito pelo ACI 222 (ACI, 2001) na Equação 2.4. Estes pesquisadores ainda afirmam que este composto é melhor do que o óxido de ferro $\left(\mathrm{Fe}_{3} \mathrm{O}_{4}\right)$ ou o óxido férrico $\left(\gamma-\mathrm{Fe}_{2} \mathrm{O}_{3}\right)$. Já Yonezawa et al. (1988, apud Moreno et al., 2004) encontraram em uma solução saturada de $\mathrm{Ca}(\mathrm{OH})_{2}$, uma película descontínua de $\mathrm{Ca}(\mathrm{OH})_{2}$ presente na superfície do metal.

A passivação tem sido tema de pesquisas e despertado a curiosidade científica do meio técnico desde o século 18 (Ferreira e Simões, 1991). Helene (1993) em seu trabalho ressalta que em 1836, mais de 170 anos atrás, o pesquisador alemão Schonbein empregou pela primeira vez a palavra passivação. Em 1918 a palavra foi 
utilizada, pela primeira vez, para explicar a proteção conferida pelo concreto à armadura (Helene, 1993).

Em 1949, o pesquisador Marcel Pourbaix, através do estudo do estado de equilíbrio termodinâmico para diversos metais propôs um diagrama de potencial-pH. $\mathrm{O}$ qual possibilitou a interpretação da corrosão metálica, assim como a classificação do estado do metal, em solução aquosa com base na eletroquímica (Delahay, 2000).

Na Figura 2.1 (Diagrama potencial-pH de Pourbaix para um eletrodo padrão de hidrogênio) é possível observar as regiões de corrosão, passivação e imunidade em um sistema ferro-água a $25^{\circ} \mathrm{C}$. De acordo com o Diagrama de Pourbaix, o ferro quando imerso em um concreto com pH superior a 9 se manterá protegido da corrosão na região de passivação, porém, somente dentro da sua faixa usual de potencial de corrosão (entre $0,1$ e $-0,5 \mathrm{~V})$. No entanto, para um potencial em torno de $-0,6 \mathrm{e}-0,8 \mathrm{~V}$ o alto $\mathrm{pH}$ do meio não garantirá passivação da armadura, pois forma-se uma região de corrosão na faixa de pH entre 13 e 14.

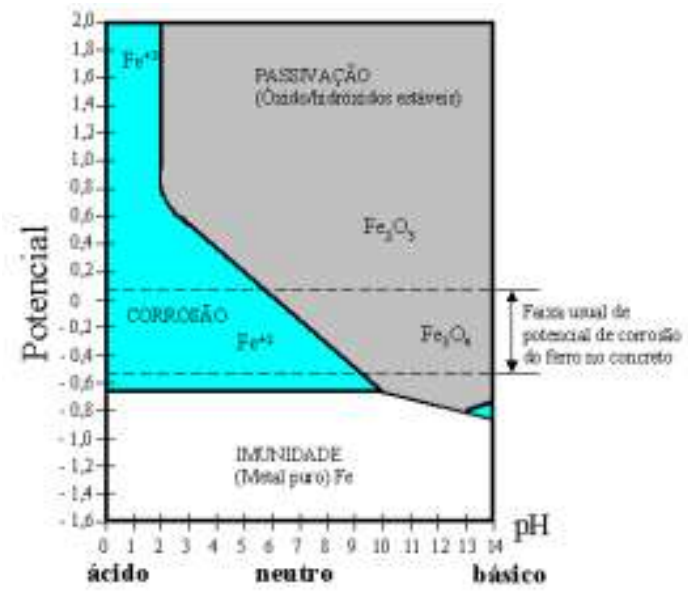

Figura 2.1. Diagrama de Pourbaix com o sistema $\mathrm{Fe}-\mathrm{H}_{2} \mathrm{O}$ a $25^{\circ} \mathrm{C}$ para um eletrodo padrão de hidrogênio, delimitando os domínios prováveis de corrosão, passivação e imunidade (Medeiros, 2002).

A região de imunidade do Diagrama de Pourbaix (Figura 2.1) corresponde à região de potencial de eletrodo menor do que $-0,6 \mathrm{~V}$ em relação ao eletrodo padrão de hidrogênio. Nestas condições, o aço não reage com o meio qualquer que seja a sua natureza, ácida, neutra ou básica. De acordo com Helene (1993), manter a armadura nestas condições corresponde ao que se denomina de proteção catódica, que tanto pode ser conseguida em determinados meios por ânodo de sacrifício quanto por corrente impressa. O Diagrama de Pourbaix é bastante utilizado para orientar inúmeras pesquisas em todo o mundo, além de ter aplicabilidade nas mais diversas áreas de conhecimento. 
Helene (1993) explica que embora o conceito de passividade tenha sido introduzido sem bases experimentais que comprovassem a sua existência e o seu mecanismo efetivo de proteção ao aço, o conceito foi consolidado. Atualmente os recursos mais efetivos de investigação da passividade são as determinações químicas e eletroquímicas de difícil interpretação devido à dinâmica do processo. E, infelizmente, as determinações e observações diretas deste filme por microscopia eletrônica têm esbarrado no problema de alteração do filme devido à necessidade de secagem e polimento das amostras (Helene, 1993).

\subsection{Perda da Película de Passivação através da Carbonatação}

A corrosão do aço no concreto é um processo eletroquímico, o qual envolve a transferência de cargas (elétrons) de um elemento químico a outro através de um meio líquido (eletrolítico), e a manifestação da corrosão se dá sob a forma de expansão, fissuras e destacamento do concreto de cobrimento.

A transferência de cargas devido à diferença de concentração de íons gera uma diferença de potencial, que em presença de oxigênio e água forma em uma pilha de corrosão na armadura imersa no concreto.

Uma vez perdida a passividade da armadura, a taxa de corrosão que antes era inferior ao valor de $0,1 \mu \mathrm{A} / \mathrm{cm}^{2}$ poderá atingir valores superiores a $1 \mu \mathrm{A} / \mathrm{cm}^{2}$, considerados elevados para armaduras em concreto estruturais. Ou seja, as reações simplificadas pelas Equações 2.1 a 2.3 (ACI, 2001) e descritas no item anterior vão ocorrer em uma velocidade muito maior do que na condição de passivação em que antes estavam inseridas as armaduras. Assim, para a reação de corrosão eletroquímica ocorrer (sem a presença de carga elétrica externa) deve existir duas regiões, uma capaz de produzir elétrons (reação de oxidação do ferro, no ânodo - Equação 2.1), e outra capaz de consumir elétrons (redução do oxigênio para formar hidroxilas, no cátodo - Equação 2.2). A reação química entre íons de ferro e as hidroxilas ocasiona a produção de um produto de corrosão, de natureza expansiva, na sua superfície (Equação 2.3).

A transformação do aço metálico em ferrugem (Equação 2.3) é acompanhada por um aumento no volume, o qual pode ser de 2 a 6 vezes superior ao volume original do aço da armadura, podendo ocasionar tensões internas maiores do que $15 \mathrm{MPa}$ (Helene, 1993). Provocando desta maneira a expansão e a conseqüente fissuração do concreto na direção paralela à direção longitudinal da armadura em 
corrosão, favorecendo a penetração da umidade (água) e do oxigênio acelerando ainda mais o processo.

De acordo com Taylor (1997), a penetração dos agentes agressivos ao interior do concreto não carbonatado depende da porosidade do mesmo. Esta porosidade pode ser alterada de acordo com o consumo de cimento, com a relação água/cimento, com o grau de compacidade dos agregados do concreto e com o tempo de cura realizado.

A porosidade do concreto determina os mecanismos de ingresso dos agentes que atacam a armadura através da absorção capilar, difusão e permeabilidade por gradiente de pressão. Uma vez despassivada a armadura, pode-se dar origem a mais um mecanismo para a penetração de agentes agressivos, a movimentação dos íons através da migração (Helene, 1993).

\subsubsection{MeCANismo da CARbOnATAÇÃo}

A carbonatação, apesar de responsável por um aumento, mesmo que pequeno, na retração, não prejudica o concreto. Muito pelo contrário, a carbonatação diminui a permeabilidade do concreto, tornando-o mais impermeável à penetração de agentes agressivos, do que são os concretos não carbonatados.

O problema é com relação aos concretos armados, pois a carbonatação reduz a alcalinidade da água dos poros do concreto, na qual a armadura está inserida. Desta forma o produto formado pela carbonatação desestabiliza quimicamente a película de passivação existente ao redor da armadura, podendo ocasionar o aumento da taxa de corrosão da armadura, se houver níveis de oxigênio e de água compatíveis para manter o processo corrosivo em taxa mais acelerada.

A carbonatação é um processo físico-químico de neutralização da fase líquida intersticial do concreto, saturada pelos compostos alcalinos formados na hidratação do cimento Portland, conforme explanado anteriormente.

A degradação do concreto armado devido à penetração do gás carbônico no mesmo é um fenômeno que ocorre de fora para dentro da estrutura, assumindo proporções mais sérias à medida que os agentes agressivos e a umidade penetram e atingem a armadura através da rede de poros existente no concreto e sua conectividade.

A carbonatação é um fenômeno que fatalmente acaba ocorrendo com o concreto à medida que o tempo passa. A compreensão deste processo químico se faz necessária à medida que a durabilidade passa a ser considerada, já que ela pode 
acarretar a modificação da estrutura da pasta de cimento, alterando a resistência, provocando pequenas retrações e, principalmente reduzindo o $\mathrm{pH}$ do concreto a valores inferiores a 9 (RILEM, 1988).

De acordo com Taylor (1997), o dióxido de carbono ao penetrar no concreto é dissolvido na água dos poros da pasta de cimento produzindo o $\mathrm{CO}_{3}{ }^{2-}$ (Equação 2.5). Sabe-se que a água nos poros da pasta de cimento Portland tem alta alcalinizada (pH entre 13 e 14) devido às hidroxilas e íons $\mathrm{Ca}^{2+}$, obtidos a partir da dissolução dos aluminatos e silicatos hidratados formados na hidratação do cimento (Equação 2.6). Desta maneira, os álcalis de cálcio $\left(\mathrm{Ca}^{2+}\right)$ existente na água dos poros do concreto irão reagir com o íon carbonato provenientes do $\mathrm{CO}_{2}$, formando o carbonato de cálcio (Equação 2.7), produto com pH em torno de 9. Desta maneira os compostos formados na hidratação do cimento serão convertidos em elementos menos alcalinos.

$\mathrm{CO}_{2}+2 \mathrm{OH}^{-} \rightarrow \mathrm{CO}_{3}^{2-}+\mathrm{H}_{2} \mathrm{O}$

(Equação 2.5)

$\mathrm{Ca}(\mathrm{OH})_{2} \rightarrow \mathrm{Ca}^{2+}+2 \mathrm{OH}^{-}$

(Equação 2.6)

$\mathrm{Ca}^{2+}+\mathrm{CO}_{3}^{2-} \rightarrow \mathrm{CaCO}_{3}$

(Equação 2.7)

Resumidamente, a perda da alcalinidade se dá devido à precipitação do carbonato de cálcio $\left(\mathrm{CaCO}_{3}\right)$ que faz com o $\mathrm{pH}$ seja da ordem de 9, alterando substancialmente a condição de estabilidade química da película passivadora do aço (Helene, 1986). Com a perda da película de passivação, devido à carbonatação, e em presença de umidade e oxigênio, a taxa de corrosão que antes era desprezível, agora assumirá uma ordem de grandeza maior e proporcional à quantidade de água e oxigênio disponível para as reações de corrosão. Na Figura 2.2 é possível observa a representação esquemática e resumida do processo de carbonatação de acordo com o CEB/BI 152 (1984).

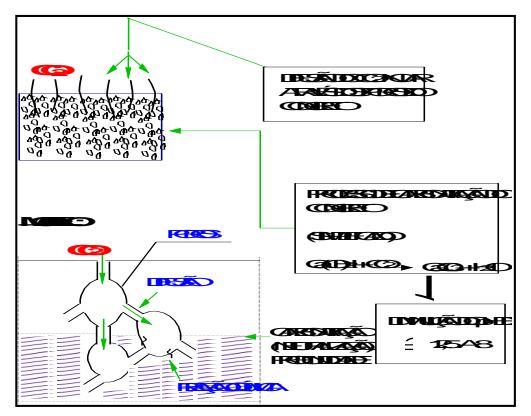

Figura 2.2. Avanço do processo de carbonatação, segundo o CEB/BI 152 (1984). 
Uma vez que a frente de carbonatação alcança uma profundidade equivalente ao cobrimento e atinge a armadura, a película de passivação não resistirá à queda do pH sendo quebrada, podendo-se estabelecer o aumento da taxa de corrosão.

\subsubsection{Velocidade da CARbonataÇÃo}

$\mathrm{Na}$ carbonatação, alguns fatores são determinantes da velocidade e da profundidade de alcance deste fenômeno. A velocidade e a profundidade de carbonatação dependem de fatores relacionados com o meio ambiente e com as características finais do concreto endurecido, conforme ilustra a Tabela 2.1.

Tabela 2.1. Principais fatores que determinam a velocidade de penetração da frente de carbonatação (Kazmierczak, 1995).

\begin{tabular}{lll}
\hline Fatores condicionantes & Características influenciadas \\
\hline \multirow{2}{*}{$\begin{array}{l}\text { Condições de } \\
\text { exposição }\end{array}$} & Concentração de $\mathrm{CO}_{2}$ & $\begin{array}{l}\text { - Mecanismo físico-químico } \\
\text { - Velocidade de carbonatação }\end{array}$ \\
\cline { 2 - 3 } & Umidade relativa do ambiente & - Grau de saturação dos poros \\
& Temperatura & - Velocidade de carbonatação \\
\cline { 2 - 3 } & $\begin{array}{l}\text { Composição química do cimento: } \\
\text { - Características do clínquer }\end{array}$ & - Porosidade da pasta carbonatada \\
Características do & - Teor de adições & - Reserva alcalina \\
\cline { 2 - 3 } & Traço & - Porosidade \\
& Qualidade da execução: & - Porosidade \\
& - Defeitos & - Grau de hidratação \\
\hline
\end{tabular}

\subsubsection{CONDIÇÕES DE EXPOSIÇÃO}

As condições de exposição podem ser classificadas de acordo com a agressividade do ambiente, tendo como base as condições de exposição da estrutura ou de suas partes, devendo levar em conta o macro e o micro-clima atuantes. A partir de uma síntese das publicações disponíveis feitas por Helene (1995), a agressividade ambiental pode ser avaliada segundo a durabilidade da armadura e do próprio concreto, considerando a classificação apresentada na Tabela 2.2.

Tabela 2.2. Classificação da agressividade do ambiente conforme a NBR 6118 (ABNT, 2003).

\begin{tabular}{ccc}
\hline Classe de agressividade & Agressividade & Risco de deterioração da estrutura \\
\hline I & fraca & insignificante \\
II & média & pequeno \\
\hline III & forte & grande \\
IV & muito forte & elevado \\
\hline
\end{tabular}




\section{a) UMIDADE RELATIVA DO AMBIENTE}

A umidade relativa do ambiente (UR) exerce influencia sobre a quantidade de água contida nos poros do concreto e esta, por sua vez, condiciona a velocidade de dissolução e difusão do $\mathrm{CO}_{2}$ através dos poros do concreto (Figueiredo et al., 1993).

Com baixas umidades, o $\mathrm{CO}_{2}$ penetra facilmente pelos poros vazios do concreto, porém, também impossibilita a sua solubilização devido à falta de água. Em concretos saturados este efeito é diferente, uma vez que a velocidade de difusão do $\mathrm{CO}_{2}$ na água é muito baixa. Assim, com os poros parcialmente preenchidos (alta umidade), ocorre a difusão do $\mathrm{CO}_{2}$ até as regiões mais internas, como também a sua solubilização e sua combinação com os produtos alcalinos dissolvidos na água dos poros (Figura 2.3).

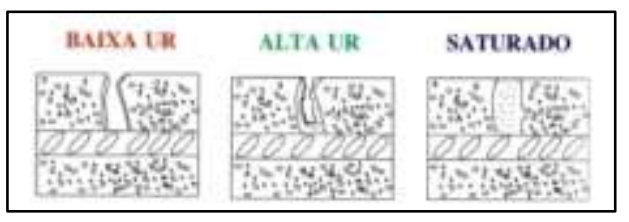

Figura 2.3. Teor de umidade dos poros do concreto em função da umidade do ambiente (Andrade, 1992).

O gráfico Verbeck (1950, apud Figueiredo et al., 1993) ilustrado na Figura 2.4 há muito tempo vem sendo a base de diversas pesquisas na área de ensaio de carbonatação acelerada, além de estar respaldada pelo ACI 301 (ACI, 1991). Neste gráfico (Figura 2.4) os maiores graus de carbonatação ocorrem quando a umidade relativa se situa entre 50 e $70 \%$ (média UR e alta difusão do $\mathrm{CO}_{2}$ ). No entanto para umidades inferiores a $20 \%$ (baixa UR) ou superiores a 95\% (meio saturado) a carbonatação ocorre lentamente ou simplesmente não ocorre.

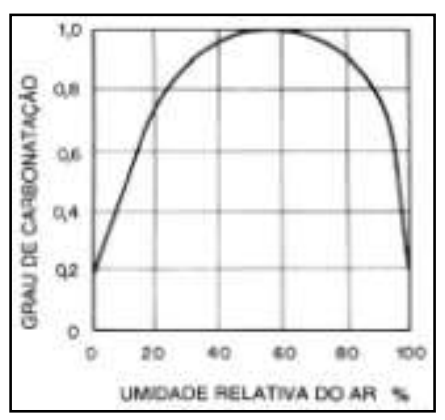

Figura 2.4. Grau de carbonatação em função da umidade relativa do ambiente (Verbeck, 1950, apud Figueiredo et al., 1993).

No entanto, uma pesquisa realizada por Roy et al. (1999) abre uma dúvida em relação à esta faixa de umidade relativa ótima entre 50 e 70\%. Pois de acordo com seus estudos, a umidade ótima para favorecer a carbonatação depende de outros fatores como a resistência do concreto e sua idade. Em seu estudo, Roy et al. (1999) verificou 
profundidade de carbonatação maiores para concreto com UR em 95\% do que na faixa de $60 \%$ de UR para concretos de idades mais avançadas (16 semanas). A Figura 2.5 ilustra os resultados obtidos pelos pesquisadores.

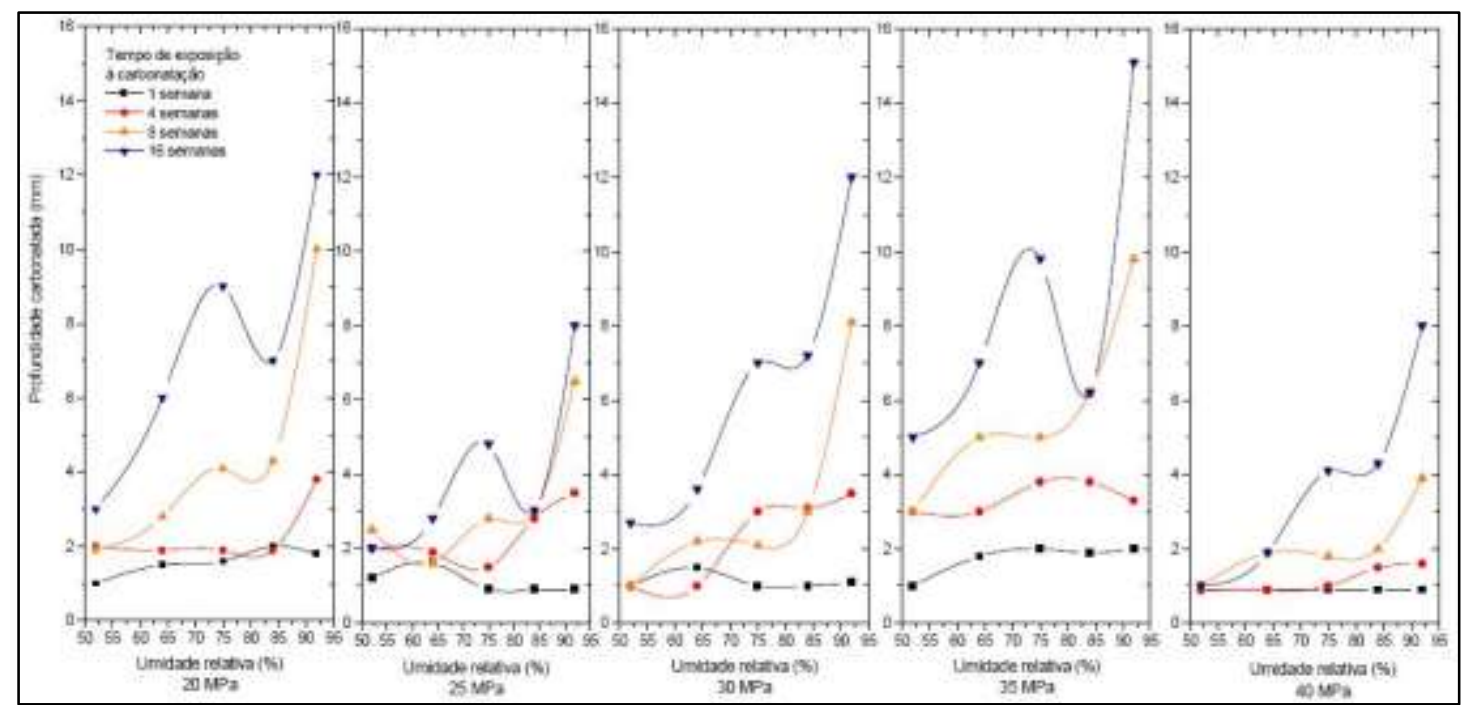

Figura 2.5. Estudo da profundidade carbonatada verso umidade relativa para diferentes classes de concreto realizado por (adaptado de Roy et al., 1999, por Abreu, 2004).

\section{b) CONCENTRAÇ̃̃O DE GÁS CARBÔNICO}

Segundo Kazmierczak (1995), a difusão do $\mathrm{CO}_{2}$ pelos poros do concreto se dá na razão direta do gradiente de concentração de $\mathrm{CO}_{2}$, de acordo com o princípio da primeira lei de Fick. Assim é possível afirmar, também, que a velocidade de carbonatação aumenta quando o ambiente possui uma maior concentração de $\mathrm{CO}_{2}$, principalmente para concretos de elevada relação água/cimento (Figueiredo et al., 1993). Uma vez que esta característica influi diretamente na qualidade do concreto, ou seja, define as características de compacidade da pasta de cimento endurecida.

A concentração de $\mathrm{CO}_{2}$ na atmosfera pode varia de $0,03 \%$ em ambientes rurais até 1,2\% em ambientes urbanos (Helene, 1986). A Tabela 2.3 mostra a correlação entre a agressividade do meio e a concentração de gás carbônico no ambiente.

Tabela 2.3. Classificação da agressividade do ambiente sobre as armaduras (Helene, 1995).

\begin{tabular}{ccc}
\hline Classe de agressividade & Macro-clima & Concentração de gás carbônico \\
\hline I & atmosfera rural & $\leq 0,3 \%$ \\
\hline II & urbana & $\leq 0,3 \%$ \\
III & marinha ou industrial & $\geq 0,3 \%$ \\
\hline IV & pólos industriais & $>0,3 \%$ \\
\hline
\end{tabular}

No entanto, para ambientes laboratoriais, a afirmação de Kazmierczak (1995) de que a difusão do $\mathrm{CO}_{2}$ pelos poros do concreto se dá na razão direta do gradiente de concentração de $\mathrm{CO}_{2}$, só é válida até um determinado teor. Pois de acordo 
com Pauletti et al. (2007) a carbonatação média em uma câmara com $6 \%$ de $\mathrm{CO}_{2}$ é aproximadamente o dobro, quando comparada com a carbonatação média em uma câmara de saturada de $\mathrm{CO}_{2}$ (Figura 2.6), ou seja, aumentar excessivamente a concentração de $\mathrm{CO}_{2}$ até a saturação reduz a velocidade de carbonatação.

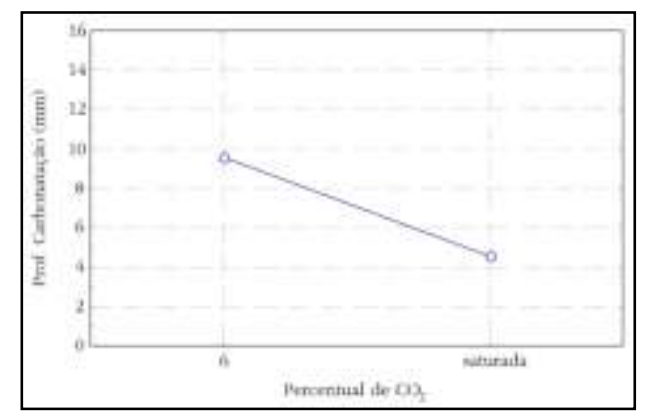

Figura 2.6. Efeito isolado do percentual de $\mathrm{CO}_{2}$ na profundidade de carbonatação (Pauletti et al., 2007).

Segundo alguns autores (Abreu, 2004, Saetta e Vitaliani, 2004, e Pauletti et al, 2007), a redução da velocidade de carbonatação em câmaras saturadas de $\mathrm{CO}_{2}$ (ou teores próximo à esta concentração) pode ser devido a produção rápida de $\mathrm{CaCO}_{3}$, e esta coincidir com a liberação de uma quantidade de água superior à liberação de água suportada pelos poros do concreto, alcançando assim a condição de equilíbrio e provocando uma queda acentuada na difusão do $\mathrm{CO}_{2}$ no interior da matriz cimentícia.

Pauletti et al. (2007) também atentam que o aumento no percentual de $\mathrm{CO}_{2}$ pode alterar as reações químicas envolvidas no processo e nos compostos formados, nas quais a carbonatação natural não alteraria. Ou seja, a alta concentração de $\mathrm{CO}_{2}$ pode provocar a carbonatação de compostos não hidratados que não ocorreria na carbonatação natural, e assim tornar os ensaios naturais e acelerados bastante distintos entre si.

Embora muitas pesquisas adotem altas concentrações de gás carbônico (acima de 20\%) para acelerar os ensaios de carbonatação, uma parcela dos pesquisadores vem adotando cada vez mais teores menores (Tabela 2.4, complementada de Pauletti et al., 2007). 
Tabela 2.4. Concentrações de gás carbônico utilizadas na carbonatação acelerada em pesquisas nacionais e estrangeiras entre os anos de 2000 e 2007 (complementada de Pauletti et al., 2007).

\begin{tabular}{|c|c|c|c|c|c|c|}
\hline Pesquisador & Ano & $\begin{array}{c}\text { Tipo de } \\
\text { material }\end{array}$ & $\mathbf{a} / \mathbf{c}$ & UR $(\%)$ & $\mathbf{T}\left({ }^{\circ} \mathbf{C}\right)$ & $\mathrm{CO}_{2}(\%)$ \\
\hline Papadakis & 2000 & argamassa & 0,5 & 61 & 25 & 3 \\
\hline Jiang et al. & 2000 & concreto & 0,37 a 0,6 & 70 & 20 & 20 \\
\hline Johannesson e Utgenannt & 2001 & argamassa & 0,55 & 65 & 20 & 1 \\
\hline Sanjuán e Olmo & 2001 & concreto & 0,6 & 70 & - & $\begin{array}{c}5,20 \text { e } \\
100\end{array}$ \\
\hline Medeiros & 2002 & $\begin{array}{c}\text { concreto } \\
\text { argamassa }\end{array}$ & $\begin{array}{c}0,4 ; 0,43 \mathrm{e} \\
0,6\end{array}$ & 65 & 24 & 5 \\
\hline Kulakowski & 2002 & $\begin{array}{l}\text { concreto } \\
\text { argamassa }\end{array}$ & $\begin{array}{c}0,4 ; 0,55 \mathrm{e} \\
0,7\end{array}$ & 70 & 25 & 5 \\
\hline Lo e Lee & 2002 & concreto & $\begin{array}{c}0,38 ; 0,46 \\
\text { e } 0,54\end{array}$ & - & 21 & 2 \\
\hline Teixeira & 2002 & argamassa & 0,4 e 0,7 & 50 & - & 100 \\
\hline Kirchheim & 2003 & concreto & $\begin{array}{c}0,4 ; 0,5 \mathrm{e} \\
0,6\end{array}$ & 70 & 25 & 100 \\
\hline Castro & 2003 & concreto & $\begin{array}{c}0,4 ; 0,55 \mathrm{e} \\
0,7\end{array}$ & 65 & 28 & 5 \\
\hline Lara & 2003 & argamassa & 0,6 e 0,75 & 70 & - & 10 \\
\hline Matsumoto et al. & 2003 & concreto & 0,54 & 60 & 30 & 5 \\
\hline Van Gerven et al. & 2004 & argamassa & $\begin{array}{c}0,34 ; 0,49 \\
\text { e } 0,60\end{array}$ & $>90$ & 37 & 5 e 20 \\
\hline Pauletti & 2004 & argamassa & $\begin{array}{c}0,4 ; 0,55 \mathrm{e} \\
0,7\end{array}$ & 70 & 20 & 6 e 100 \\
\hline Abreu & 2004 & concreto & $\begin{array}{l}0,44 ; 0,48 \\
0,55 \text { e } 0,65\end{array}$ & 70 & 25 & 5 e $>50$ \\
\hline Gervais et al. & 2004 & argamassa & 0,35 & 23,48 e 98 & - & 100 \\
\hline Araujo & 2004 & concreto & 0,4 e 0,7 & 50 & $25 \pm 5$ & 100 \\
\hline Sá & 2006 & concreto & 0,4 e 0,7 & 50 & $25 \pm 5$ & 100 \\
\hline Galvão e Cascudo & 2006 & argamassa & 0,4 & 60 & 26 & 8 \\
\hline Chang e Chen & 2006 & concreto & 0,65 & 70 & 23 & 20 \\
\hline Vaghetti & 2006 & concreto & $\begin{array}{c}0,5 ; 0,6 \mathrm{e} \\
0,7\end{array}$ & 75 & 20 & 10 \\
\hline Isaia e Gastaldini & 2006 & concreto & $\begin{array}{c}0,35 ; 0,45 \\
\text { e } 0,55\end{array}$ & 65 & 23 & 5 \\
\hline Castellote et al. & $2006 a$ & pasta & 0,5 & 65 & 20 & 100 \\
\hline Gonen e Yazicioglu & $2007 \mathrm{a}$ & concreto & 0,38 e 0,5 & 55 & - & 40 \\
\hline Song e Kwon & 2007 & argamassa & 0,55 e 0,65 & 65 & 25 & 5 \\
\hline Sullivan-Green et al. & 2007 & argamassa & 0,5 & 85 & 20 & 100 \\
\hline Villain et al. & 2007 & concreto & $\begin{array}{c}0,53 ; 0,62 \\
\text { e } 0,84\end{array}$ & 53 & 20 & 45 \\
\hline Thiery et al. & 2007 & concreto & $\begin{array}{c}0,48 ; 0,62 \\
\text { e } 0,84\end{array}$ & 53 & 21 & 50 \\
\hline Gonen e Yazicioglu & $2007 b$ & concreto & 0,53 & 35 & - & 40 \\
\hline Tong et al. & 2008 & concreto & 0,7 & 60 & 22 & 50 \\
\hline
\end{tabular}




\subsubsection{CARACTERÍSTICAS DO CONCRETO}

\section{a) COMPOSICÃO QUÍMICA DO CIMENTO}

A quantidade disponível de compostos alcalinos para reagir com o $\mathrm{CO}_{2}$ depende do tipo de cimento empregado na produção do concreto.

Segundo Figueiredo et al. (1993), a bibliografia é praticamente unânime em concluir que os cimentos com adições apresentam um desempenho inferior aos cimentos Portland comum no que se refere a resistência à carbonatação, quando se trata de concretos convencionais.

A Figura 2.7 mostra que a adição de cinza volante ao concreto de cimento Portland fez com que aumentasse a carbonatação, o mesmo ocorrendo quando a quantidade de cimento ou cimento mais cinza volante, por metro cúbico, foi diminuída.

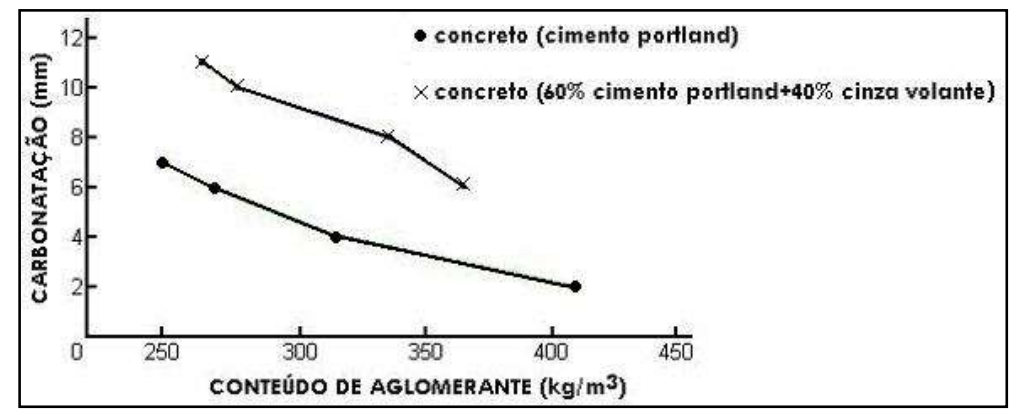

Figura 2.7. Influencia do tipo de cimento e sua quantidade por $\mathrm{m} 3$ sobre a profundidade de carbonatação (Ho e Lewis, 1987, apud Figueiredo et al., 1993).

Por outro lado, Castro (2003) comprova que esta afirmação não é válida para todos os tipos de adições. Apenas para adições de cinza volante, casca de arroz e escória de alto-forno, pois a sílica ativa e a metacaulinita propiciaram maiores ganhos de desempenho ao concreto, demonstrando que as alterações micro-estruturais proporcionadas por estas adições ao concreto foram mais eficientes que as prováveis reduções da reserva alcalina na proteção da frente de carbonatação. A Figura 2.8 ilustra esta afirmação, na qual foram estudados concretos sem adição, chamados de referência (R), com escória de alto-forno (E), sílica ativa (S), cinza volante (V), cinza de casca de arroz (A) e metacaulinita (M). 


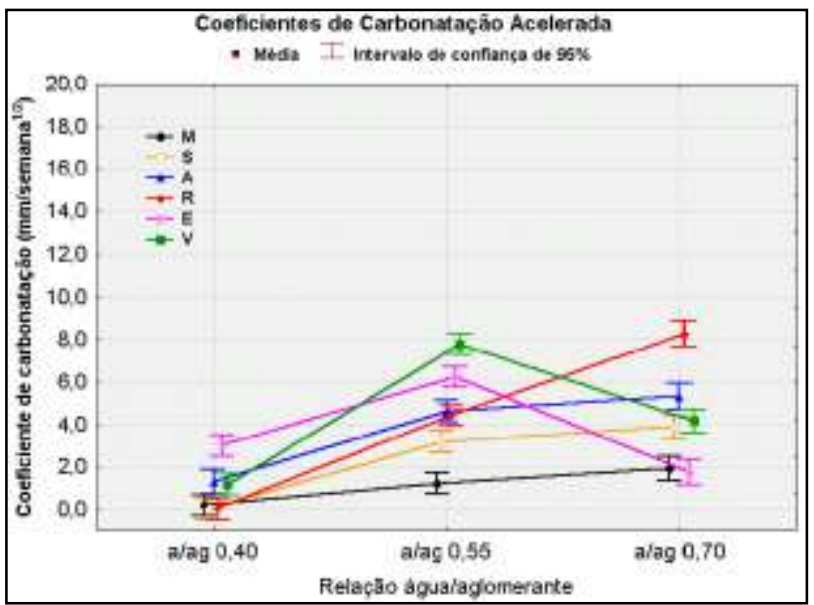

Figura 2.8. Coeficiente de carbonatação médios, para cada relação água/aglomerante, para concretos que passaram por cura úmida (Castro, 2003).

\section{b) $\underline{\operatorname{TRACO}}$}

A composição do concreto define a porosidade, a difusividade, a absorção e a permeabilidade da pasta endurecida e se reflete na velocidade de penetração da frente de carbonatação. A relação água/cimento está intimamente ligada à quantidade e tamanho dos poros do concreto endurecido, e com as propriedades mecânicas finais do material.

A Figura 2.9 mostra que quanto maior a relação água/cimento, mais facilidade o $\mathrm{CO}_{2}$ terá de se difundir através do concreto devido à porosidade existente.

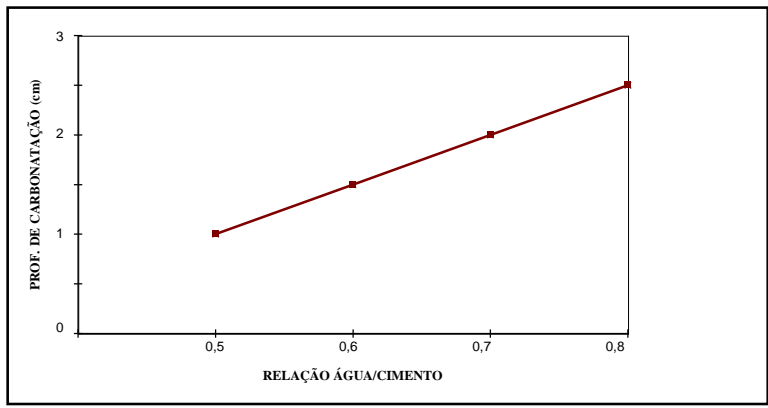

Figura 2.9. Influencia da relação água/cimento sobre a profundidade de carbonatação (Figueiredo et al., 1993).

\section{c) QUALIDADE DA EXECUCÃO}

Falhas de execução podem causar alterações na estrutura física do concreto endurecido, tais como fissuras, ninhos de concretagem, perda da pasta de cimento, entre outros, provocando, devido à heterogeneidade do concreto, a aceleração na frente de carbonatação.

Acredita-se que qualquer fissura presente no concreto facilite a entrada dos agentes agressivos no interior das estruturas de concreto armado, comprometendo assim 
a sua durabilidade. No entanto, de acordo com a NBR 6118 (ABNT, 2003) as fissuras da ordem de $0,3 \mathrm{~mm}$ em concreto armado, facilitam a penetração dos agentes agressivos se a peça estiver inserida em um ambiente de agressividade II a IV (Tabela 2.5). Ainda segundo a NBR 6118 (ABNT, 2003), se o ambiente no qual a peça de concreto armado estiver for de agressividade I, somente as fissuras de espessura superior a $0,4 \mathrm{~mm}$ é que vão representar perigo.

Tabela 2.5. Classificação da agressividade do ambiente em função de micro e macroclimas de acordo com a NBR 6118 (ABNT, 2003).

\begin{tabular}{|c|c|c|c|c|}
\hline \multirow{3}{*}{ Macro-clima } & \multicolumn{4}{|c|}{ Micro-clima } \\
\hline & \multicolumn{2}{|c|}{ Ambientes internos } & \multicolumn{2}{|c|}{ Ambientes externos e obras em geral } \\
\hline & $\begin{array}{c}\text { Seco }^{(1)} \\
\mathrm{UR} \leq 65 \%\end{array}$ & $\begin{array}{l}\text { Úmido ou ciclos }^{(2)} \text { de } \\
\text { molhagem e secagem }\end{array}$ & $\begin{array}{c}\text { Seco }^{(3)} \\
\mathrm{UR} \leq 65 \%\end{array}$ & $\begin{array}{l}\text { Úmido ou ciclos }^{(4)} \text { de } \\
\text { molhagem e secagem }\end{array}$ \\
\hline Rural & I & I & I & II \\
\hline Urbana & I & II & I & II \\
\hline Marinha & II & III & - & III \\
\hline Industrial & II & III & II & III \\
\hline Especial (5) & II & III ou IV & III & III ou IV \\
\hline Respingo de maré & - & - & - & IV \\
\hline Submersa $\geq 3 \mathrm{~m}$ & - & - & - & I \\
\hline Solo & - & 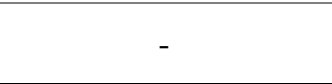 & $\begin{array}{c}\text { não agressivo } \\
\text { I }\end{array}$ & $\begin{array}{c}\text { úmido e agressivo II, III } \\
\text { ou IV }\end{array}$ \\
\hline \multicolumn{5}{|c|}{$\begin{array}{l}\text { (1) Salas, dormitórios, banheiros, cozinhas e áreas de serviço de apartamentos residenciais e conjuntos } \\
\text { comerciais ou ambientes com concreto revestido com argamassa e pintura. } \\
\text { (2) Vestiários, banheiros, cozinhas, lavanderias industriais e garagens. } \\
\text { (3) Obras em regiões de clima seco, e partes da estrutura protegidas de chuva em ambientes } \\
\text { predominantemente secos. } \\
\text { (4) Ambientes quimicamente agressivos, tanques industriais, galvanoplastia, branqueamento em indústrias de } \\
\text { celulose e papel, armazéns de fertilizantes, indústrias químicas. } \\
\text { (5) Macro clima especial significa ambiente com agressividade bem conhecida, que permite definir a classe } \\
\text { de agressividade III ou IV nos ambientes úmidos. Se o ambiente for seco, deve ser considerada classe de } \\
\text { agressividade II nos ambientes internos e classe de agressividade III nos externos. }\end{array}$} \\
\hline
\end{tabular}

Com relação à cura do concreto, é consensual no meio científico que a cura é um fator de extrema importância para a durabilidade das estruturas de concreto, mas geralmente é negligenciada. Quanto maior o tempo e a qualidade da cura, maior será o grau de hidratação do cimento e menor será a porosidade do concreto e, conseqüentemente, sua permeabilidade.

O cobrimento da armadura deve ser calculado conforme o prescrito pela NBR 6118 (ABNT, 2003), na qual a garantia do cobrimento mínimo ( $\mathrm{c}_{\text {mín }}$ ) é dada pelo cobrimento nominal $\left(\mathrm{c}_{\mathrm{nom}}\right)$, considerado no projeto e na execução, acrescido da tolerância de execução $(\Delta c)$. Nas obras, o valor de $\Delta$ c deve ser maior ou igual a $10 \mathrm{~mm}$, 
porém, quando houver um controle rígido de qualidade adequado, o valor de $\Delta \mathrm{c}$ baixa para $5 \mathrm{~mm}$. Neste caso, a exigência de controle rigoroso deve ser explicitada nos desenhos de projeto. Assim, os espaçadores devem estar de acordo com os cobrimentos nominais, estabelecidos na Tabela 2.6, para $\Delta \mathrm{c}=10 \mathrm{~mm}$.

Tabela 2.6. Correspondência entre classe de agressividade ambiental e cobrimento nominal para $\Delta \mathrm{c}=10 \mathrm{~mm}$ conforme prescreve a NBR 6118 (ABNT, 2003)

\begin{tabular}{lccccc}
\hline \multirow{2}{*}{ Tipo de estrutura } & \multirow{2}{*}{$\begin{array}{c}\text { Componente ou } \\
\text { elemento }\end{array}$} & \multicolumn{4}{c}{ Classe de agressividade ambiental } \\
\cline { 3 - 6 } & & I & II & III & IV $^{(3)}$ \\
\hline \multirow{2}{*}{ Concreto armado } & Laje & & Cobrimento nominal (mm) & \\
& Viga/Pilar & 20 & 25 & 35 & 45 \\
Concreto protendido $^{(1)}$ & Todos & 30 & 30 & 40 & 50 \\
\hline
\end{tabular}

(1) Cobrimento nominal da armadura passiva que envolve a bainha ou os fios, cabos e cordoalhas, sempre superior ao especificado para o elemento de concreto armado, devido aos riscos de corrosão fragilizante sob tensão.

(2) Para a face superior de lajes e vigas que serão revestidas com argamassa de contra-piso, com revestimentos finais secos tipo carpete e madeira, com argamassa de revestimento e acabamento, tais como pisos de elevado desempenho, pisos cerâmicos, pisos asfálticos e outros tantos, as exigências desta tabela podem ser substituídas, respeitado um cobrimento nominal $\geq 15 \mathrm{~mm}$.

(3) Nas faces inferiores de lajes e vigas de reservatórios, estações de tratamento de água e esgoto, condutos de esgoto, canaletas de efluentes e outras obras em ambientes química e intensamente agressivos, a armadura deve ter cobrimento nominal $\geq 45 \mathrm{~mm}$.

Os cobrimentos nominais e mínimos estão sempre referidos à superfície da armadura externa, em geral à face externa do estribo. O cobrimento nominal de uma determinada barra deve sempre ser:

$$
\begin{aligned}
& c_{\text {nom }} \geq \phi \text { barra } \\
& c_{\text {nom }} \geq \phi \text { feixe }=\phi_{n}=\phi \sqrt{n} \\
& c_{\text {nom }} \geq 0,5 \phi \text { bainha }
\end{aligned}
$$

A dimensão máxima característica do agregado graúdo, utilizado no concreto não pode superar em $20 \%$ a espessura nominal do cobrimento, ou seja:

$$
\mathrm{d}_{\max } \leq 1,2 \mathrm{c}_{\text {nom }}
$$

\subsubsection{Modelo Clássico para Estimativa da Profundidade DE CARBONATAÇÃO}

De acordo com Kazmierczak (1995), a Equação 2.7, descrita a seguir, foi proposta por japoneses, durante a década de 30, para estimar a profundidade da frente de carbonatação, utilizado a primeira lei de Fick.

$$
e_{\mathrm{co} 2}=e_{0}+k_{\mathrm{CO} 2} \sqrt{t}
$$


Onde:

$e_{\mathrm{CO} 2}$ é a profundidade de penetração do $\mathrm{CO}_{2} \mathrm{em} \mathrm{mm}$;

$\mathrm{e}_{0}$ é espessura da camada carbonatada ao início da medição;

$\mathrm{k}_{\mathrm{CO} 2}$ é uma constante que depende das características do concreto e do ambiente ao qual está exposto $\left(\mathrm{mm} / \mathrm{ano}^{1 / 2}\right)$;

t é o tempo de exposição ao $\mathrm{CO}_{2}$ em anos.

\subsection{Estudo da Película de Proteção da Armadura através de Técnicas ELETROQUímicas}

No âmbito laboratorial de ensaios acelerados de corrosão, a constatação da formação da película de passivação vem sendo pouco abordada por algumas pesquisas (Flis e Zakroczymski, 1996; Vaghetti, 2006; Díez-Pérez et al., 2006; entre outros). Pois, não há por parte destes estudos procedimentos que permitam se reservar um período de tempo para a formação da película de passivação ao redor da armadura, ou se estabelecem períodos muito curtos para sua concepção. Ou seja, as armaduras são colocadas em ambiente agressivo sem evidências da formação da película de passivação. A situação mais apropriada seria proporcionar à armadura um período adequado de espera para possibilitar a formação da película de passivação, evitando a ocorrência de erros de análise do comportamento da corrosão e, conseqüentemente, erros relativos a previsão de vida útil. Constatação esta também abordada no estudo realizado por Poursaee e Hansson (2007), no qual os autores ressaltam a inexistência de pesquisas abordando o tempo necessário para a armadura se tornar passiva quando em contato com a água dos poros do concreto.

De Acordo com Poursaee e Hansson (2007) e Araujo (2004), o tempo necessário para a formação da película de passivação ao redor da armadura pode variar de 7 dias a quatro meses.

Poursaee e Hansson (2007) estudaram a determinação do período necessário para passivação com dois sistemas diferentes. Um de barras imersas em argamassas de cimento Portland, com traço $1: 3$ e a/c 0,45, e outro com barras imersas diretamente na solução de água dos poros formulada pelos pesquisadores (Tabela 2.7). A determinação do período de passivação foi realizada através de medidas de resistência de polarização linear e de medida de potencial de corrosão. 
Tabela 2.7. Simulação da solução da água dos poros (Poursaee e Hansson, 2007).

\begin{tabular}{cc}
\hline Material & Quantidade \\
\hline $\mathrm{NaOH}$ & 9,17 gramas \\
\hline $\mathrm{KOH}$ & 31,4 gramas \\
\hline $\mathrm{CaSO}{ }_{4} \cdot 2 \mathrm{H}_{2} \mathrm{O}$ & 0,96 gramas \\
$\mathrm{Ca}(\mathrm{OH})_{2}$ & 4,2 gramas \\
\hline Água & 1,75 litros \\
\hline
\end{tabular}

Ao final dos ensaios, os pesquisadores Poursaee e Hansson (2007) concluíram que os potenciais somente entraram na faixa tida como segura (>-200 mV) depois de aproximadamente 7 dias, isto para as barras imersas diretamente na solução alcalina. $\mathrm{Na}$ análise dos resultados dos potenciais das barras imersas nos corpos-deprova de argamassa (Figura 2.10. (a)), os potenciais de corrosão não conseguiram chegar a faixa de probabilidade de corrosão inferior a $5 \%(<-200 \mathrm{mV})$, se mantiveram na faixa descrita como "incerta" de acordo com a ASTM C876 (1991). Já nas barras imersas diretamente na solução de água dos poros formulada (Figura 2.10. (b)), os resultados apresentaram potenciais eletroquímicos menos eletronegativos do que 200 mV. Ou seja, com base nas recomendações da ASTM C876 (1991), as armaduras imersas nos corpos-de-prova de argamassa não mostraram valores de potencial aplicáveis para estágios iniciais de passivação da armadura, quando a película está sendo desenvolvida.

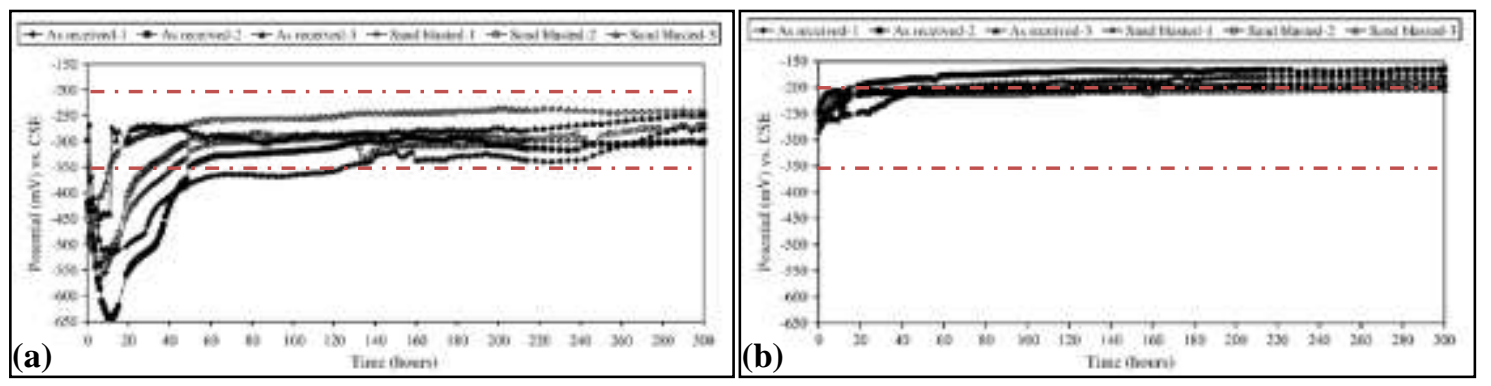

Figura 2.10. (a) Valores de potencial da armadura imersa em argamassa por 300 horas. (b) Valores de potencial da armadura imersa por 300 horas em solução de poros formuladas (Poursaee e Hansson, 2007).

No estudo de Araujo (2004) as barras imersas em um concreto com cimento Portland tipo II-Z especificado pela NBR 11578 (ABNT, 1991) e com relação a/c de 0,40, demorou cerca de 130 dias (aproximadamente 4 meses) para atingir um potencial de corrosão na faixa de risco inferior a 5\% de probabilidade de corrosão (Figura 2.11). 


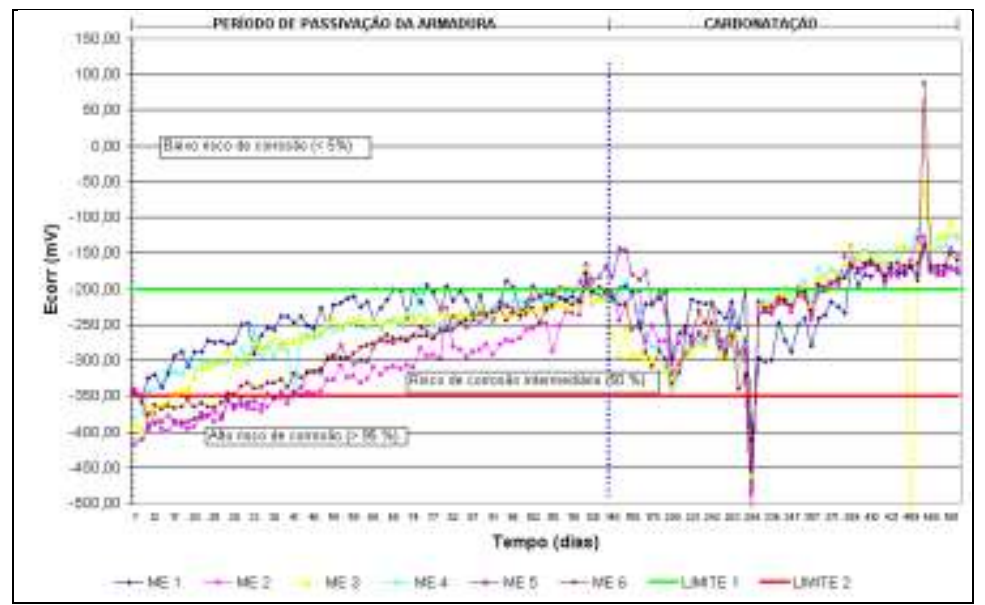

Figura 2.11. Potenciais de corrosão obtidos através do GECOR6 para concreto de relação a/c 0,40 (Araujo, 2004).

Andrade, et al. (1995) também verificaram a formação da película de passivação em argamassas de cimento Portland com relação a/c 0,60, utilizando medidas de espectroscopia de impedância eletroquímica (EIE). Porém, os autores não abordam o tempo necessário para a formação da película de passivação, apenas constatam a sua formação através da técnica citada.

Assim como no estudo da formação da película de passivação, são muitas as técnicas desenvolvidas para a detecção, identificação, avaliação, caracterização e monitoramento da corrosão. Técnicas estas de grande importância para o controle do fenômeno, seja na prevenção, como na terapia das estruturas com problemas.

A grande vantagem das técnicas eletroquímicas sobre as demais técnicas é devido ao seu caráter não destrutivo. Com estas técnicas é possível realizar uma análise preliminar do estado da armadura da estrutura analisada no próprio local, através dos resultados da medida da taxa e do potencial de corrosão, levando em consideração a resistência ôhmica do concreto no qual a armadura estudada está inserida. 


\section{REALCALINIZAÇÃO DO CONCRETO CARBONATADO}

A técnica de realcalinização deve ser empregada para restabelecer a alcalinidade do concreto carbonatado através da elevação do $\mathrm{pH}$, assim como proporcionar a repassivação da armadura, condições perdidas com a entrada do dióxido de carbono no interior do concreto. Com base nesta definição foi possível apurar quais pesquisas estavam abordando somente a realcalinização do concreto carbonatado e quais abordaram o escopo da realcalinização como um todo. Ou seja, quais pesquisas verificaram tanto a realcalinização do concreto carbonatado quanto a sua eficácia eletroquímica (i.e. repassivação da armadura).

Dentre as bibliografias pesquisadas, apenas um terço abordava a eficácia ou não da repassivação da armadura (Odden, 1994; Andrade et al., 1999; González et al., 2000; Miranda et al., 2003, Yeih e Chang, 2005, Tong et al., 2008 e Araujo e Helene, 2008) através da realcalinização eletroquímica. As demais bibliografias disponíveis, ou tratavam apenas da realcalinização do concreto ou se detinham apenas em revisões bibliográficas a respeito da técnica (Mietz e Isecke, 1993 e 1996; NCT, 1996; McGovern, 1996; Silva, 1996; Eggers e Oliveira, 1997; Banfill, 1994, 1996 e 1997; Mietz, 1998; Velivasakis et al., 1998; Whitmore et al., 1999; Mattila e Pentti, 1999; Mandeno, 1999; Matsumoto et al., 2003; Castellote et al., 2003, 2006a e 2006b; Islam e Daily, 2006, e Araujo et al., 2009).

Dentre as pesquisas que estudaram a repassivação das armaduras, não há um consenso, ainda, com relação à eficácia da técnica eletroquímica na reconstituição da película de passivação. No entanto, mesmo com a falta de consenso em relação à eficácia da técnica, a realcalinização, seja como técnica preventiva ou de reabilitação, tem a vantagem de não necessitar a remoção do concreto carbonatado. Procedimento este onde, geralmente, apenas a camada de concreto destacada, mal aderida, com defeitos de concretagem ou degradada é que necessita ser retirada e reparada antes do início do tratamento. 


\subsection{Princípio da RealCalinizaÇão}

$\mathrm{Na}$ literatura existente são três os mecanismos fundamentais para o restabelecimento da alcalinidade do meio que rodeia a armadura. O primeiro é através da difusão e absorção de uma solução alcalina por ação capilar e de forças hidráulicas (realcalinização química), que independem do campo elétrico e do fluxo de corrente aplicado. O segundo e o terceiro ocorrem com o uso de corrente elétrica e consequiente formação de um campo elétrico (realcalinização eletroquímica). Sendo o segundo através da produção de íons hidroxilas $\left(\mathrm{OH}^{-}\right)$, devido à reação catódica na superfície das armaduras, e o terceiro através de um fluxo eletro-osmótico, que transporta a solução alcalina para o interior dos poros capilares do concreto.

Os benefícios encontrados em relação à técnica de realcalinização eletroquímica estão diretamente ligados ao tipo de eletrólito utilizado durante o tratamento da estrutura. São muitos os autores, como Odden (1994), Kennedy et al. (1995), Eggers e Oliveira (1997), Banfill (1997), Mietz (1998), Miller (1998), Andrade et al. (1999), Yeih e Chang (2005), Castellote et al. (2003 e 2006a e b), entre outros, que consagram o carbonato de sódio (na concentração de $1 \mathrm{M}$ ) como o melhor eletrólito encontrado para realcalinizar eletroquimicamente o concreto carbonatado. Isto por manter um pH constante em torno de 10,5, sendo este valor favorável para a formação e manutenção da película. No entanto, alguns pesquisadores não descartam o estudo de eletrólitos diferentes, que proporcionem à armadura um ambiente suficientemente alcalino para a formação da película de passivação (Tabela 3.1).

Tabela 3.1. Composição e $\mathrm{pH}$ de soluções alcalinas utilizadas por diferentes pesquisadores para proporcionar a formação da película de passivação nas armaduras.

\begin{tabular}{lcl}
\hline Composição & pH & Pesquisador \\
\hline $1 \mathrm{M} \mathrm{K}_{2} \mathrm{CO}_{3}$ & - & Fosroc (s/d) \\
\hline $0,6 \mathrm{M} \mathrm{NaOH}+0,18 \mathrm{M} \mathrm{KOH}+\mathrm{Ca}(\mathrm{OH})_{2}$ (saturado) & 13,6 & Flis e Zakroczymski (1996) \\
\hline Solução saturada de $\mathrm{Ca}(\mathrm{OH})_{2}$ & - & Gonzáles et al. (2000) \\
\hline $\mathrm{Na}_{2} \mathrm{CO}_{3}(20 \mathrm{~g} / 100 \mathrm{ml})$ & - & Teixeira (2002) \\
\hline Solução saturada de $\mathrm{Ca}(\mathrm{OH})_{2}$ & - & Miranda et al. (2003) \\
\hline $2 \mathrm{~N} \mathrm{Li}_{3} \mathrm{BO}_{3}$ & 12 & Matsumoto et al. (2003) \\
\hline Solução saturada de $\mathrm{Ca}(\mathrm{OH})_{2}$ & 12,5 & Moreno et al. (2004) \\
\hline $0,9 \mathrm{M} \mathrm{NaOH}^{2} \mathrm{Na}_{3}(3 \mathrm{~g} / 100 \mathrm{ml})$ & 13,9 & Moreno et al. (2004) \\
\hline $\mathrm{KOH}(15 \mathrm{~g} / 100 \mathrm{ml})$ & 12 & Araujo (2004) e Sá (2006) \\
\hline Tripla: $\mathrm{Na}_{2} \mathrm{CO}_{3}+\mathrm{KOH}+\mathrm{NaOH}(1,5 \mathrm{e} 1,5 \mathrm{~g} / 100 \mathrm{ml})$ & 13 & Araujo (2004) e Sá (2006) \\
\hline
\end{tabular}

A Fosroc (sd), por exemplo, constatando que há formação de cristais na superfície da estrutura reabilitada através da realcalinização eletroquímica quando utilizado o carbonato de sódio como eletrólito, estudou a substituição deste carbonato pelo de potássio e obteve resultados satisfatórios. Outro exemplo é o estudo de Sergi et 
al. (1996), apud Mietz (1998), que utilizaram o hidróxido de lítio como eletrólito. Os autores afirmam que o LiOH comparado com o carbonato de sódio, possui o mesmo pH necessário para restauração da película de passivação, porém, tem a vantagem dos íons de lítio permanecerem por mais tempo no interior da estrutura do que os íons sódio e potássio.

Matsumoto et al. (2003) compararam a utilização do $\mathrm{Li}_{3} \mathrm{BO}_{3}$ com o $\mathrm{Na}_{2} \mathrm{CO}_{3}$ como eletrólito. Os resultados obtidos mostraram que o efeito da realcalinização eletroquímica com o $\mathrm{Li}_{3} \mathrm{BO}_{3}$ foi tão eficaz quanto com o carbonato de sódio, além de ter mantido o mesmo pH do carbonato de sódio após um ano de finalizado o tratamento. Os autores constataram também, através da utilização de agregados reativos, que as taxas de expansão, devido à reação álcali-agregado, foram inferiores às obtidas nos ensaios onde o carbonato de sódio foi utilizado como eletrólito.

Tomando como base a bibliografia referente à realcalinização eletroquímica, Araujo e Figueiredo (2005), visando a viabilização da realcalinização química por absorção e difusão, utilizaram em seus experimentos eletrólitos diferentes do usualmente empregado na realcalinização eletroquímica (o carbonato de sódio). Os pesquisadores observaram que estas soluções alcalinas foram tão eficientes quanto a solução alcalina de carbonato de sódio para realcalinizar $2,5 \mathrm{~cm}$ de argamassa carbonatada (Figura 3.1).

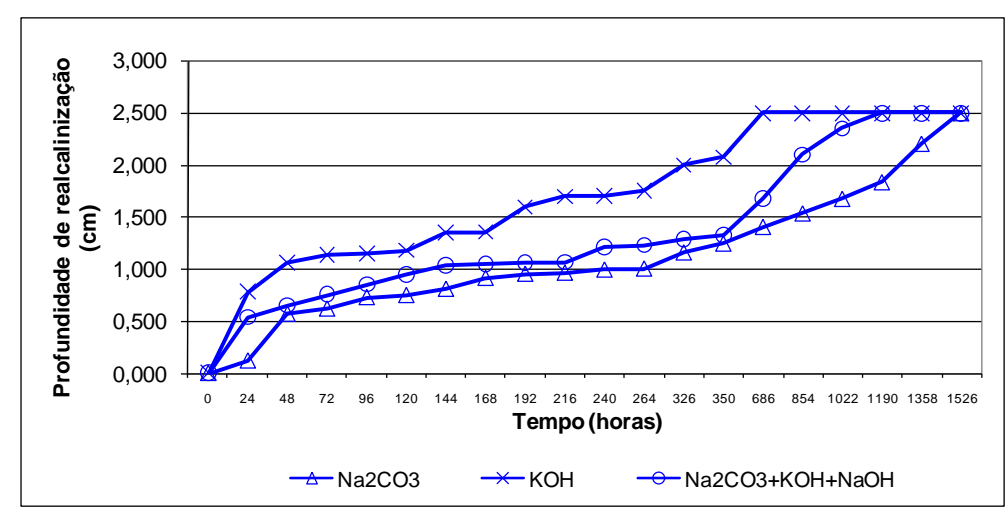

Figura 3.1. Velocidade da realcalinização química com diferentes soluções alcalinas utilizadas por Araujo e Figueiredo (2005).

De acordo com Araujo et al. (2007a), todas as soluções alcalinas por eles estudadas (carbonato de sódio, hidróxido de potássio e uma mistura alcalina de carbonato de sódio, hidróxido de potássio e hidróxido de sódio) forneceram o mesmo valor de pH final (12,5) ao concreto após a realcalinização. Araujo et al. (2007b) verificaram que os corpos-de-prova realcalinizados por Araujo et al. (2007a) após um ano e meio ainda apresentavam o mesmo $\mathrm{pH}$. 


\subsubsection{REALCALINIZAÇÃo ElETROQUímicA (RAE)}

No início dos anos 70, a Administradora das Rodovias Federais dos Estados Unidos (US Federal Highway Administration - FHWA) investigou diferentes tipos de proteção para corrosão das armaduras através de tratamentos eletroquímicos temporários. O que resultou em um programa de pesquisa estratégico para rodovias (Strategic Highways Research Program - SHRP), o qual utilizou em larga escala a extração eletroquímica de cloretos, que seria desenvolvida mais tarde (NCT, 1996). No entanto foi na Europa, no início dos anos 80, onde foram desenvolvidos os dois métodos eletroquímicos de recuperação de concreto armado, a realcalinização eletroquímica e a extração eletroquímica de cloretos. Ambas as técnicas foram desenvolvidas pela empresa norueguesa Norwegian Concrete Technologies (NCT), ou NORCURE Inc. (Yeih e Chang, 2005), a qual mais tarde foi incorporada à Fosroc Internacional (Mandeno, 1999).

De acordo com Whitmore et al. (1999), até o final dos anos 90, mais de 1,2 milhões de metros quadrados de concretos foram tratados com as técnicas desenvolvidas pela NCT. Sendo largamente utilizada pelos engenheiros na Europa, no Japão, na Austrália e no norte dos Estados Unidos.

A técnica de realcalinização eletroquímica permite atacar o problema da carbonatação do concreto armado em uma fase precoce, reduzindo os custos de intervenção e prolongando a vida útil da estrutura (Silva, 1996).

Esta técnica restabelece a proteção contra a corrosão da armadura pelo aumento da alcalinidade do concreto através do processo eletro-osmótico. No qual os álcalis da solução alcalina, aplicada na superfície da estrutura a ser tratada, entram no concreto devido à aplicação de corrente elétrica, favorecendo a criação de um campo elétrico entre a superfície do concreto e a armadura. De acordo com Eggers e Oliveira (1997) nos poros capilares existe uma camada dupla de moléculas de água interligadas por forças elétricas, a camada mais interna é fortemente aderida às paredes dos poros, enquanto a externa é ligada de forma menos intensa. Quando um campo elétrico é aplicado, uma parte da camada externa se move para um dos pólos, extraindo a água livre dos poros e propiciando a formação de íons hidroxila $\left(\mathrm{OH}^{-}\right)$, íons estes também responsáveis pelo aumento do valor de $\mathrm{pH}$.

Independente da diferença de potencial elétrico aplicado, o coeficiente de fluxo eletro-osmótico é proporcional à espessura da camada dupla e decresce com o 
aumento da concentração iônica da água no poro capilar. Uma vez que a concentração iônica da água contida nos poros capilares do concreto carbonatado é baixa, o transporte eletro-osmótico é considerado como um possível mecanismo para aumentar a sua alcalinidade (Kennedy et al., 1995). De acordo com Gonçalves et al. (2003), a eletroosmose trará, ainda, o benefício de provocar um tamponamento nos poros da estrutura reabilitada, dificultado a re-entrada do $\mathrm{CO}_{2}$ na estrutura.

No entanto, a formação e a manutenção da película repassivadora de óxidos e hidróxidos de ferro sobre a superfície das armaduras dependerá dos íons alcalinos introduzidos ao concreto pelo processo de realcalinização. Mietz (1998) qualifica a realcalinização eletroquímica como o método mais eficaz para a restauração da película passivadora que foi perdida.

A metodologia do tratamento consiste na aplicação, durante 1 ou 2 semanas, de um campo elétrico, oriundo da aplicação de uma corrente entre 0,2 e $8 \mathrm{~A} / \mathrm{m}^{2}$ através de uma fonte retificadora (Gonçalves et al., 2003). Esta fonte retificadora irá ligar a armadura, que se encontra no interior do concreto, ao ânodo externo, colocado sobre o concreto. $\mathrm{O}$ ânodo externo, geralmente de titânio, é uma malha condutora imersa em um eletrólito e localizada na superfície do concreto carbonatado. O titânio é o metal mais utilizado como ânodo por se tratar de um metal bastante nobre, cujo seu consumo se dá lentamente e os produtos de corrosão são menos expansivos. Em geral, para possibilitar o contato do eletrólito com a superfície do concreto carbonatado é utilizada uma polpa de celulose saturada projetada sob o concreto. A polpa de celulose pode ainda ser substituída por fibras projetadas, por feltro e no caso de lajes as bordas podem ser seladas formando tanques (NCT, 1996).

Com a aplicação da corrente externa na armadura, a armadura passa a funcionar como um cátodo, produzindo, através da eletrólise da água, hidrogênio e hidroxila. Assim, a solução alcalina transportada para o interior do concreto carbonatado, em conjunto com as hidroxilas formadas ao redor da armadura, proporciona um ambiente bastante alcalino. Embora a produção de hidroxila favoreça o aumento do $\mathrm{pH}$ do concreto, também pode ocasionar problemas como a fragilização da armadura por hidrogênio e diminuir a aderência existente entre a armadura e o concreto (Gonçalves et al., 2003). Apesar dos efeitos colaterais mencionados, a realcalinização eletroquímica segue como uma opção viável para reparar estruturas de concreto carbonatadas. O princípio descrito da realcalinização eletroquímica está ilustrado na Figura 3.2. 


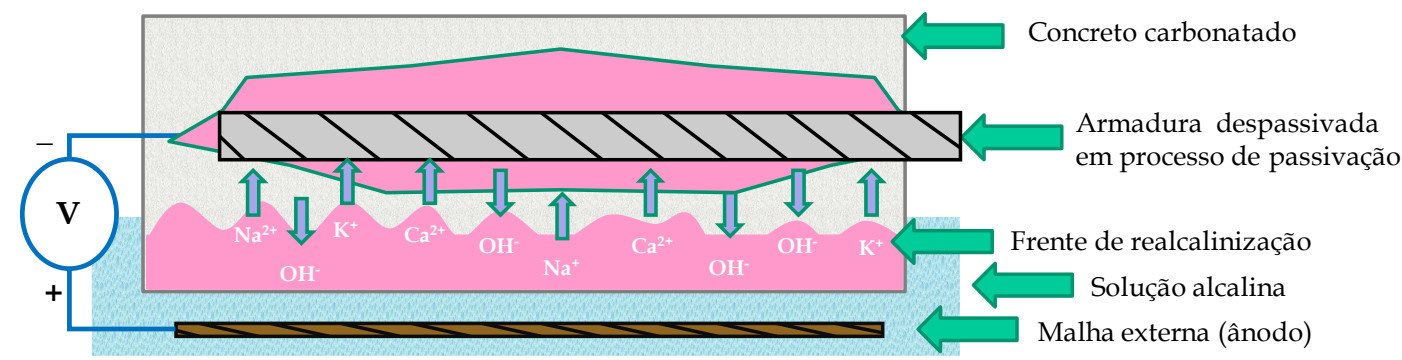

Figura 3.2. Princípio da realcalinização eletroquímica (adaptada de Araujo, 2004).

Eggers e Oliveira (1997) ressaltam que o transporte eletro-osmótico nem sempre ocorre. O fluxo eletro-osmótico em concreto carbonatado contendo cloretos tem o seu coeficiente diminuído, uma vez que a presença do sal diminui a espessura da camada dupla de moléculas de água nas paredes dos poros. Outra experiência que mostrou uma diminuição do fluxo eletro-osmótico foi a impregnação do concreto com película polimérica de base silano ou siloxano. Segundo os autores, uma razão para este fenômeno é a quebra da continuidade da dupla camada de moléculas de água ligadas por forças elétricas logo na superfície do concreto. Outra explicação é o fato do concreto estar protegido superficialmente, dificultando a movimentação iônica.

Segundo Gonçalves et al. (2003), caso seja necessário realizar reparos na estrutura antes do início do tratamento, deve-se verificar a existência de continuidade elétrica entre as armaduras de forma a garantir a eficácia da técnica de realcalinização eletroquímica. Caso a continuidade elétrica esteja prejudicada, deve-se estabelecer conexões adicionais entre as armaduras para não ocasionar a formação de macro-pilhas de corrosão. Outro cuidado é quanto à continuidade eletrolítica do concreto para estabelecer o circuito de corrente internamente. A existência de fissuras, de concreto desagregado, de ninhos de concretagem ou de outros defeitos, pode comprometer a passagem uniforme do fluxo de corrente. Antes de realizar a realcalinização eletroquímica, deve-se conhecer a espessura do cobrimento, pois, uma espessura de cobrimento uniforme garantirá a homogeneidade do fluxo de corrente durante o tratamento eletroquímico. Por último, antes de qualquer método eletroquímico de reabilitação, é necessário realizar uma limpeza na superfície do concreto para eliminar qualquer vestígio de poeira ou graxa (Gonçalves et al., 2005).

A eficácia da técnica de realcalinização eletroquímica também está ligada à extensão da área tratada. Gonçalves et al. (2003) afirmam que quanto menor a zona tratada, mais sensível é o controle do sistema e a comprovação da ausência de curtoscircuitos. Além do mais, se em uma mesma estrutura existem partes que necessitam de 
diferentes densidades de corrente e possuem diferenças significativas de resistividade, as regiões devem ser tratadas separadamente. Como regra geral não é recomendada que as zonas de tratamento tenham uma extensão maior do que $100 \mathrm{~m}^{2}$.

A corrente elétrica introduzida no concreto é cessada quando a realcalinização atinge o nível desejado. Isto ocorre cerca de uma semana depois de iniciado o tratamento e verificado através da aspersão de soluções alcoólicas de indicadores químicos na superfície das amostras retiradas do local tratado.

\subsubsection{REALCALINIZAÇÃO QUÍMICA (RAQ)}

A realcalinização química por absorção e difusão de soluções alcalinas no interior do concreto carbonatado, assim como a eletroquímica, tem a finalidade de elevar o $\mathrm{pH}$ do concreto carbonatado, empregando soluções ricas em álcalis, porém, sem o uso de corrente elétrica.

Esta realcalinização consiste na absorção e difusão de soluções alcalinas por ação capilar e de forças hidráulicas para o interior do concreto carbonatado, não dependendo de aplicação de campo elétrico e de fluxo de corrente, como é o caso da realcalinização eletroquímica. A realcalinização química do concreto carbonatado ocorre através dos capilares dos poros do concreto. Nos quais a forças hidráulicas farão com que a solução alcalina seja absorvida para o seu interior. Neste ínterim, os íons alcalinos contidos na solução reagem com os produtos contidos na água dos poros formando novos produtos. Estes novos produtos formados propiciam a elevação do pH do concreto, assim como a fixação dos álcalis no interior do mesmo até atingir a região da armadura, provocando a sua repassivação. A Figura 3.3 ilustra o processo de realcalinização química por absorção e difusão.

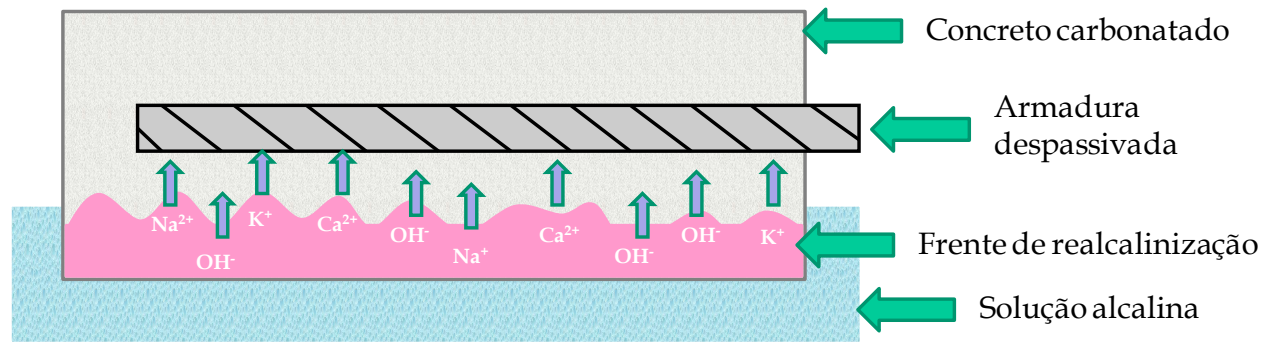

Figura 3.3. Esquema da realcalinização química (adaptada de Araujo, 2004).

O primeiro estudo desta técnica registrado no Brasil foi o realizado por Teixeira (2002), no qual se mostrou uma técnica tão eficiente quanto a realcalinização 
eletroquímica, com a vantagem de não exigir equipamentos sofisticados e o acompanhamento de profissionais especializados.

Teixeira (2002) verificou a eficácia da realcalinização de argamassas com diferentes tipos de cimentos existentes no Brasil (puros, com filer, pozolânicos, de escória e de alta resistência inicial). Em todos os casos a realcalinização mostrou ser bastante eficiente, principalmente com relação ao tempo necessário para realcalinizar os 2,5 cm de argamassa. As argamassas de relação água/cimento igual a 0,40 moldadas com o cimento de alta resistência inicial (CP V - ARI), classificadas segundo o pesquisador como as de condição de maior dificuldade de reabilitação, precisou de 408 horas (17 dias) para realcalinizar por completo o cobrimento de 2,5 cm (Figura 3.4).

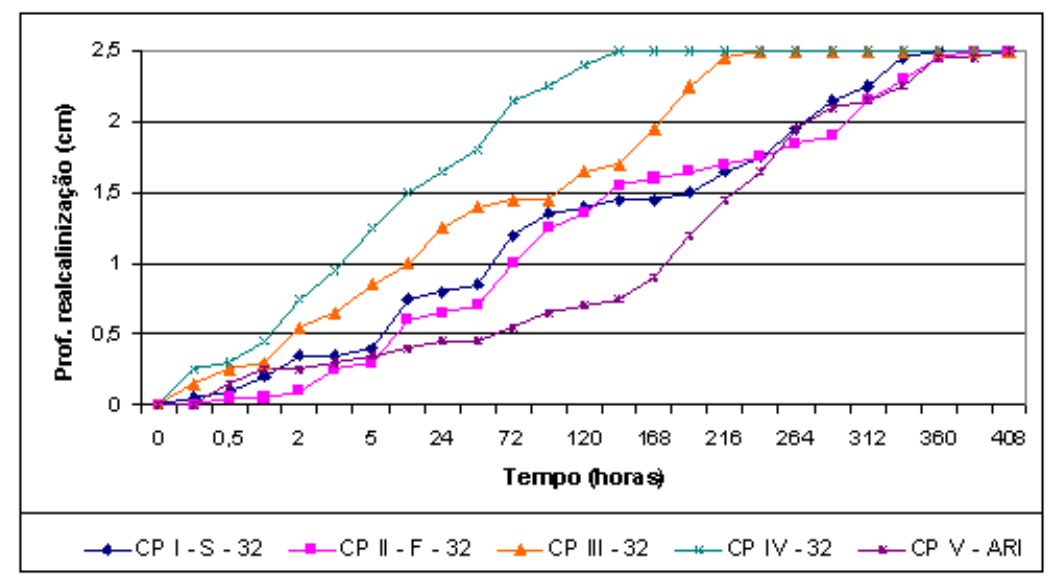

Figura 3.4. Realcalinização química por absorção e difusão para relação água/cimento 0,4 (Teixeira, 2002).

A cada biênio novos estudos em relação à técnica de realcalinização química são realizados (Teixeira, 2002; Araujo, 2004; e Sá, 2006), e novas publicações são disponibilizadas ao meio científico (Figueiredo et al., 2004; Araujo e Figueiredo, 2005; Araujo et al., 2005; Araujo et al., 2007a; Araujo et al., 2007b; Araujo et al., 2007c; Araujo e Helene, 2008; e Araujo et al., 2009). A grande quantidade de publicação sobre o tema proporciona o avanço experimental da técnica de RAQ através de diversos grupos de pesquisa em todo país (em Goiânia com Professor Enio Pazini Figueiredo - UFG, em São Paulo com Professor Paulo Helene - USP, e em João Pessoa com o Professor Gibson Meira - CEFET/PB). Embora a técnica ainda não esteja viabilizada tecnicamente, os resultados obtidos até o momento favorecem a continuidade do estudo com outros pesquisadores e instituições, e a futura aplicabilidade da técnica. 


\subsection{Efeitos Colaterais Possíveis com o uso da Realcalinização EleTroquímica E QUímica}

Dentre as técnicas de reparo eletroquímico disponíveis, a realcalinização eletroquímica é a que menos produz efeitos colaterais, uma vez que a duração da técnica e a densidade de corrente aplicada são as menores quando comparadas com as técnicas de proteção catódica e a extração eletroquímica de cloretos. No entanto, nem todos os efeitos colaterais em razão da realcalinização eletroquímica podem ser atribuídos a aplicação de corrente. Por esta razão, tais efeitos foram abordados nesta revisão, a fim de realizar um comparativo entre as duas técnicas de realcalinização aqui descritas.

\subsubsection{REAÇÃo ÁlCALI-AgREGAdo (RAA)}

De acordo com Miller (1998), reações entre agregados e álcalis são normais, inofensivas e até benéficas durante o processo de endurecimento do concreto. As reações álcali-agregado (RAA) são achadas em diversos graus e na maioria dos concretos, podendo provocar tanto a expansão como a contração.

Miller (1994) explica que para ocorrer a reação álcali-agregado com maior ou menor intensidade, ou mesmo não ocorrer, aspectos como as características do agregado, a umidade do concreto, a quantidade de íons alcalinos devido o tipo de cimento utilizado e o pH da água dos poros devem ser levados em consideração.

Quando a realcalinização é realizada, duas condições favoráveis à reação álcali-agregado são disponibilizadas ao concreto, a umidade e o aumento do $\mathrm{pH}$ no interior do mesmo.

Com base em dados disponíveis nos estudos de Andrade et al. (1997), Miller (1998), Mietz (1998) e Haboubi (2000), a RAA, caso ainda não tenha sido iniciada, teoricamente não será desenvolvida com a realização da realcalinização, pois o pH final, ou seja, o pH estabilizado, após a realcalinização fica em torno de 10,5, impossibilitando a ocorrência da reação. No entanto, esta suposição não se confirma em estudos com experimentos que verificaram a reação álcali-agregado.

No estudo de Banfill (1999), citado por Gonçalves et al. (2003), foi verificada a ocorrência da reação álcali-agregado nos concretos com agregados reativos, totalmente carbonatado e, posteriormente realcalinizado, embora estes concretos tenham expandido menos do que o mesmo concreto não carbonatado, tido como referência. Embora o autor utilize esta menor expansão encontrada nos concretos realcalinizados, para afirmar que a reação álcali-agregado não impossibilita o tratamento da 
carbonatação através da realcalinização eletroquímica. Isto não é o suficiente para garantir a inocuidade da técnica em relação a RAA.

Por exemplo, Miller (1998) acredita que o perigo da RAE está nos álcalis migrarem da região realcalinizada para a região não carbonatada, onde o $\mathrm{pH}$ se mantém intacto (em torno de 12,5), estando nas condições ideais para a ocorrência da RAA. Entretanto, Mattila et al. (1996), apud Miller (1998), afirmam que esta situação é difícil de ocorrer na prática, pois os íons alcalinos não poderiam migrar de uma região realcalinizada ( $\mathrm{pH}$ em torno de 10,5) para a não carbonatada (maior que 12) devido a lentidão do processo de difusão, comprovado com ensaios em laboratório em estruturas com mais de 5 anos de tratamento finalizado (Odden, 1994).

Não obstante ao fato de existirem informações convergindo para a crítica da realcalinização devido às reações de expansão provocadas pela RAA. É necessário atentar ao fato de que, se o agregado presente em uma estrutura de concreto com mais de 10 anos nunca apresentou indício de RAA com o pH original, a reação não haveria de ser iniciada com a utilização da técnica de realcalinização, visto que o pH restabelecido será similar ao apresentado anteriormente pelo concreto. É importante ressaltar que a ocorrência da RAA depende de três fatores trabalhando em conjunto: umidade, alcalinidade e reatividade do agregado, se um deles faltar, a RAA estaria impossibilitada de ocorrer.

Em relação à umidade, Miller (1994) afirma que as reações expansivas oriundas da RAA só ocorrem em concretos com umidade constante entre $80 \%$ e $100 \%$, nunca em concretos saturados ou submersos. Como a técnica de realcalinização se enquadra justamente na condição de saturação do concreto, condição está que não propicia a formação do gel expansivo. Então, é importante ressaltar que após a finalização do tratamento, o concreto voltará a condição de umidade anterior ao tratamento, condição esta que nos anos anteriores nunca propiciou a reação.

O tipo, a quantidade e o tamanho dos agregados presentes na mistura do concreto também é uma ponto decisivo da reação álcali-agregado. Pois, está no agregado o foco do problema e este influencia diretamente na susceptibilidade do concreto em relação à reação álcali-agregado.

Portanto, uma vez sabendo da existência do agregado potencialmente reativo no concreto e, principalmente, caso a reação já esteja ocorrendo, as técnicas eletroquímicas devem ser evitadas. Pois, o efeito da aplicação da RAE pode ou não maximizar o efeito da reação, e também porque não haveria certeza se a reação álcali 
agregado pode vir a se tornar um efeito possível no concreto tratado. Assim, deve-se evitar o tratamento eletroquímico em concretos com agregados reativos, sendo esta a mesma recomendação especificada pelo Comitê Europeu de Normalização - CEN. O CEN ressalta na norma européia EN 14038-1 (CEN, 2005), que se a estrutura de concreto na qual será aplicada a realcalinização conter agregados sensíveis aos álcalis, o risco de provocar a reação álcali-agregado deve ser considerado antes de qualquer tratamento.

No entanto, caso não seja possível deixar de realizar a realcalinização, podese prevenir a reação utilizando como eletrólito a solução de borato de lítio, pois o silicato de lítio formado no tratamento é insolúvel e menos propenso à expansão (Page e $\mathrm{Yu}, 1995)$. Mesmo sendo um procedimento comprovado, deve-se tomar cuidado com a concentração inadequado do lítio, a qual, ao invés de evitar a reação, pode provocar uma expansão ainda maior.

\subsubsection{Perda da AderÊNCiA de ReVestimentos Externos com o Substrato}

\section{REALCALINIZADO}

Possíveis falhas no sistema de revestimento aplicados na superfície do concreto tratado foram identificadas nas estruturas de concreto que passaram, tanto pelo processo de realcalinização eletroquímica quanto pelo de extração eletroquímica de cloretos. Esses problemas podem ocorrer depois de dias ou semanas após a aplicação do revestimento nas estruturas tratadas (Fosroc, sd). Os principais problemas encontrados foram de empolamento, fissuração e destacamento dos revestimentos de pintura, além da presença de eflorescência. Esta deficiência nos sistemas de pintura tem sido vista e negligenciada pelos responsáveis na realização da realcalinização eletroquímica (Fosroc, sd). Na Tabela 3.2 é possível encontrar as falhas, e os fatores causadores das mesmas, com a realização da RAE. 
Tabela 3.2. Fatores que reduzem a aderência e aumentam a pressão de descolamento da pintura ao substrato realcalinizado eletroquimicamente (Fosroc, sd).

\section{Fatores que reduzem a aderência}

Absorção da água pelo eletrólito de sódio, dificultando a secagem da superfície.

Este processo gera um substrato úmido, o qual reduz a penetração da pintura no substrato.

Formação de cristais na superfície seca, prejudica a penetração da pintura.

Secagem rápida da superfície recém pintada provoca a formação inadequada do filme devido à dispersão do revestimento.

Dispersão do revestimento pelo eletrólito, ocasionando a formação de um filme fraco.

As pinturas em concretos realcalinizados eletroquimicamente podem apresentar falhas devido a uma combinação de fatores, uma fraca aderência com o aumento na pressão de vapor gerada pelo acúmulo de água provocado pelo sal no interior da estrutura, modificando assim o equilíbrio entre o concreto e o sistema de pintura (Fosroc, sd).

A Fosroc (sd) menciona que o maior problema está na utilização do carbonato de sódio como eletrólito para a manutenção da passivação da armadura, pois este eletrólito é o causador da eflorescência (acúmulo de sal) formada na superfície do concreto tratado. Uma possível solução seria identificar outro eletrólito com a mesma capacidade de repassivação da armadura, com baixo custo e que evite a formação do sal na superfície do concreto tratado. A Fosroc (sd), ainda em fase de estudo, sugere que a utilização do carbonato de potássio, ao invés do de sódio, pode ser a solução para o problema em questão. Pois, a utilização do carbonato de potássio, parece não provocar o aparecimento de eflorescência, mantendo a estrutura limpa (Fosroc, sd).

Araujo et al. (2009) realizaram diversos ensaios de resistência de aderência com aplicação de argamassas ou pinturas sobre substratos de argamassa não carbonatados, chamados de referência, carbonatados e realcalinizados; com o objetivo de verificar se a realcalinização química influenciaria na aderência dos tipos de revestimentos testados.

Os resultados obtidos com a utilização de argamassas industrializadas permitiram constatar que a realcalinização química não prejudica a aderência das mesmas no substrato tratado, observando-se ainda que a RAQ aumentou a aderência das 
argamassas colantes AC-I (para interiores) e AC-II (para exteriores) no substrato (Figura 3.5 e Figura 3.6).

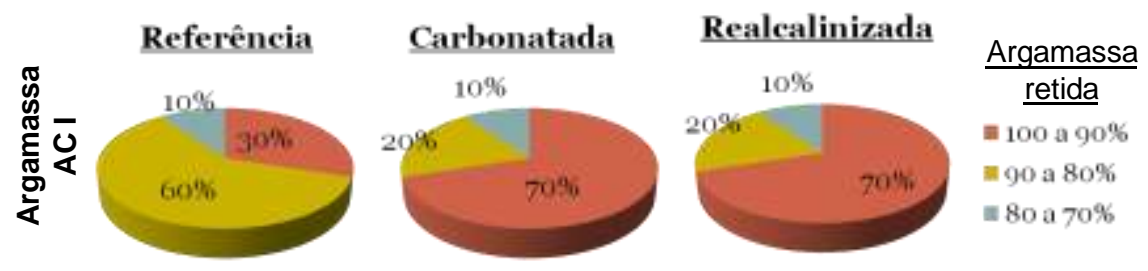

Figura 3.5. Quantidade de argamassa AC I retida após o ensaio de arrancamento em diferentes substratos (Araujo et al., 2009).

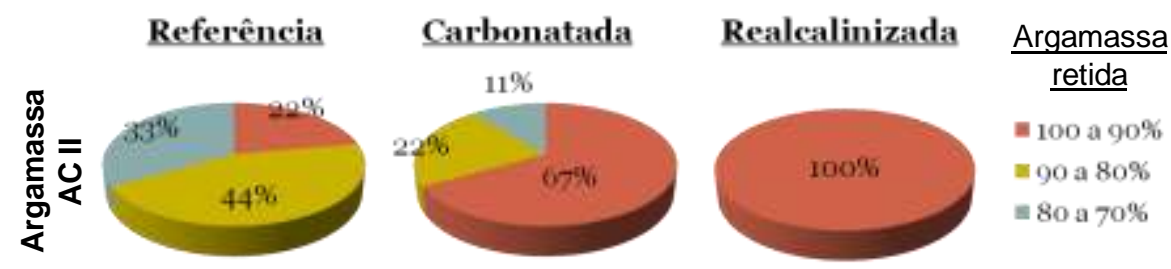

Figura 3.6. Quantidade de argamassa AC II retida após o ensaio de arrancamento em diferentes substratos (Araujo et al., 2009).

No caso da utilização de pinturas, observou-se nos ensaios de aderência que as películas não permaneceram aderidas ao substrato após a finalização do ensaio (Figura 3.7), assim como relatado pela Fosroc (sd) quando se utilizou a realcalinização eletroquímica.
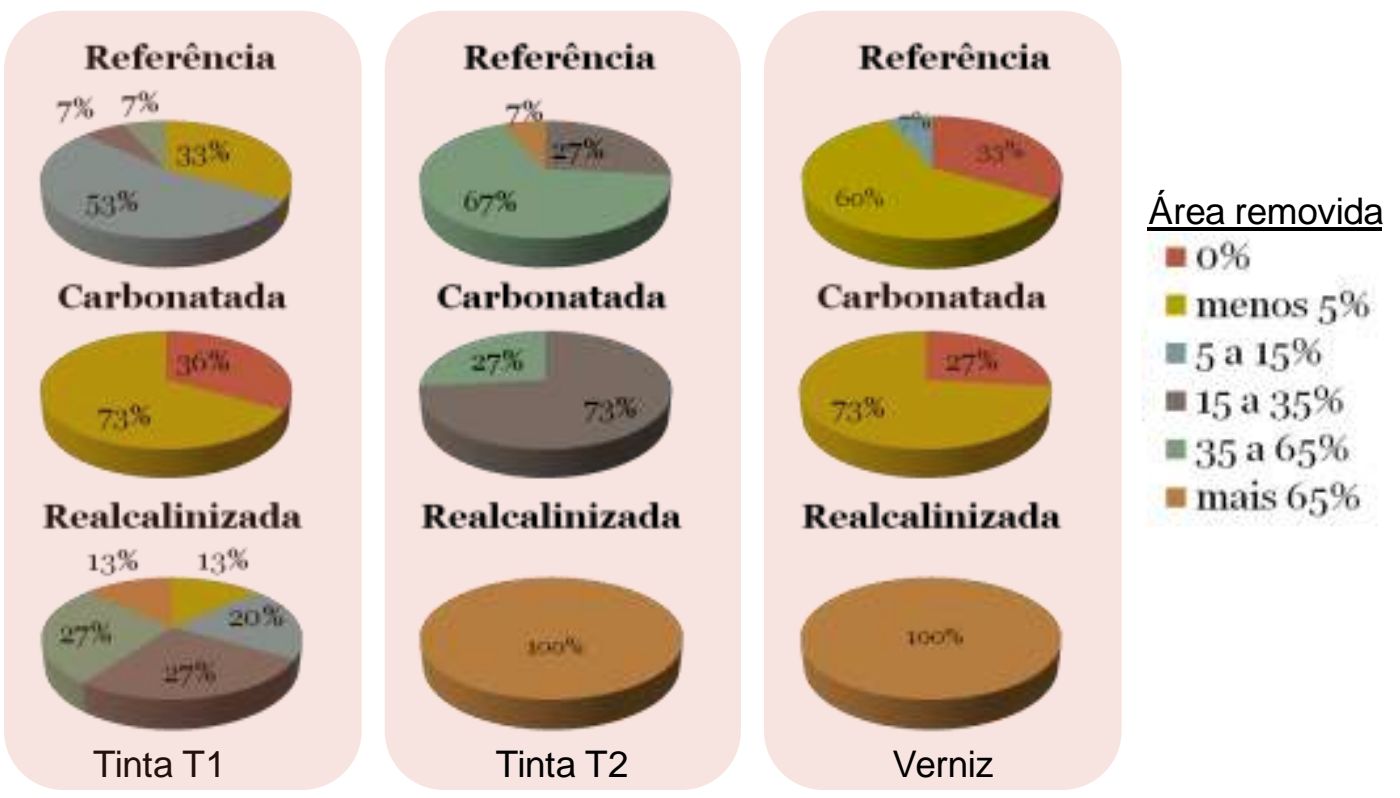

Figura 3.7. Porcentagem de área removida para cada um dos sistemas de pintura estudados (Araujo et al., 2009). 
No estudo publicado por Araujo et al. (2007c) são apresentadas e discutidas alternativas para evitar o aparecimento de eflorescência na superfície do concreto. Os resultados obtidos indicam que a utilização de hidróxido de potássio como eletrólito, que resultou na não formação do sal na superfície do concreto tratado, e a diminuição da concentração do carbonato de sódio na solução utilizada na realcalinização, que resultou na diminuição da eflorescência na superfície do concreto, são alternativas viáveis para amenizar o problema da eflorescência quando se utiliza a realcalinização. Embora, mesmo com a utilização destas alternativas, a pintura realizada no substrato realcalinizado apresentou ainda assim falta de aderência. Os autores recomendam como uma opção ao combate da perda de aderência da pintura no substrato realcalinizado, a prescrição de uma limpeza com jato de água para a retirada do excesso de sal acumulado após a finalização do tratamento.

Já os estudos de aderência de revestimentos de argamassas industrializadas em substratos realcalinizados, realizados por Araujo et al. (2005), não apresentaram qualquer problema de aderência devido à realização da realcalinização.

\subsubsection{Alteração das Propriedades Químicas E Físicas do CONCRETO}

\section{REALCALINIZADO}

É consenso dentre os pesquisadores, que a carbonatação favorece a colmatação dos poros do concreto devido o carbonato de cálcio formado na reação entre o gás carbônico do ambiente externo e os produtos de hidratação do cimento, aumentando a resistividade do concreto e diminuindo a porosidade do mesmo. De acordo com Gonçalves et al. (2005), a corrente aplicada na realcalinização eletroquímica implicaria em uma movimentação das espécies iônicas contidas na fase aquosa dos poros, alterando o equilíbrio sólido-líquido da matriz. Esta alteração iônica provocaria modificações na porosidade total do concreto, assim como na distribuição do tamanho dos poros.

Yeih e Chang (2005) verificaram que a RAE provoca um pequeno incremento da resistividade do concreto em função do aumento da densidade de corrente aplicada durante o tratamento eletroquímico. Este aumento da resistividade deve ser, provavelmente, devido a formação do bicarbonato de sódio $\left(\mathrm{NaHCO}_{3}\right)$ nos poros do concreto. Já o aumento da densidade do concreto, ocasionou em uma leve diminuição na absorção de água, confirmando, segundo os autores, que a realcalinização reduz a absorção de água (Figura 3.8), e conseqüentemente o volume de poros totais. 
Em relação à quantidade de corrente aplicada durante o tratamento, a absorção de água tem uma leve diminuição com o aumento da densidade de corrente (Figura 3.9).

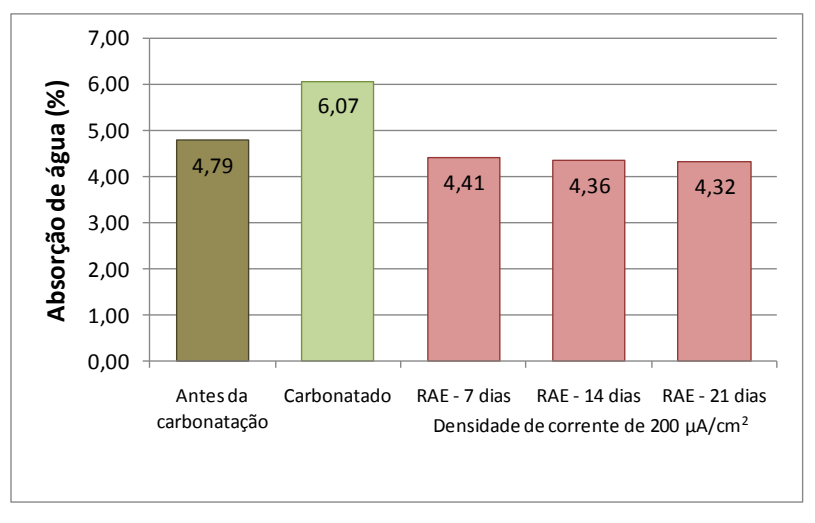

Figura 3.8. Redução da absorção de água em função da RAE (baseado dos dados de Yeih e Chang, 2005).

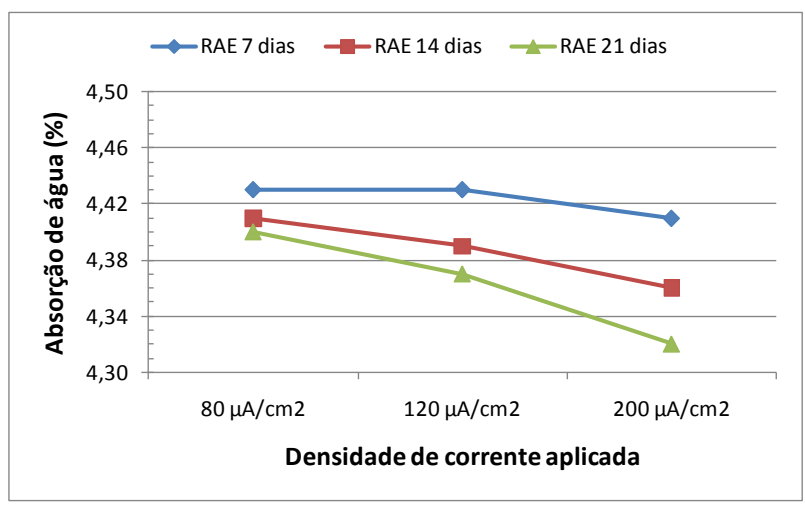

Figura 3.9. Redução da absorção de água em função da densidade de corrente aplicada durante o tratamento de RAE (baseado dos dados de Yeih e Chang, 2005).

Já no estudo realizado por Al-Kadhimi et al. (1996), apud Mietz (1998), foi constatado que a houve sim uma mudança na distribuição dos poros, ocorrendo à diminuição do seu diâmetro. Situação na qual, o total de água absorvida, a absorção capilar e a absorção superficial inicial, todos apresentaram uma diminuição. Os autores explicam que a realcalinização eletroquímica provoca a deposição de materiais (do eletrólito) nos poros do concreto, ocasionando na densificação do concreto. Banfill (1996) verificou, através da porosimetria por intrusão de mercúrio, que houve uma diminuição dos poros do concreto tanto na região próxima do ânodo quando no cátodo do concreto realcalinizado, embora na região próxima ao cátodo tenha mostrado uma absorção inferior à região próxima ao ânodo.

Outras propriedades do efeito da realcalinização eletroquímica nas propriedades mecânicas do concreto também foram abordadas por Al-Kadhimi et al. (1996, apud Banfill, 1996), Mietz (1998), e Banfill (1994 e 1997). Nestas pesquisas 
foram encontradas alterações, tanto nas estruturas carbonatadas quanto nas realcalinizadas, na velocidade de pulso ultra-sônico e na resistência à compressão, em ambas seus valores nos concretos cresceram significativamente. Nos ensaios de resistência à flexão e de módulo elástico dinâmico, os pesquisadores também encontraram um aumento significativo nos resultados.

De acordo com Yeih e Chang (2005), a resistência à compressão, o módulo de elasticidade e a resistência de aderência entre a barra e o concreto diminuem linearmente em relação à densidade de corrente aplicada $\left(\mu \mathrm{A} \cdot \operatorname{dias} / \mathrm{cm}^{2}\right)$ durante $\mathrm{o}$ tratamento de RAE (Figura 3.10). A diminuição da resistência, segundo os autores, é provavelmente devido ao ataque sofrido gel de C-S-H pelo cátodo.
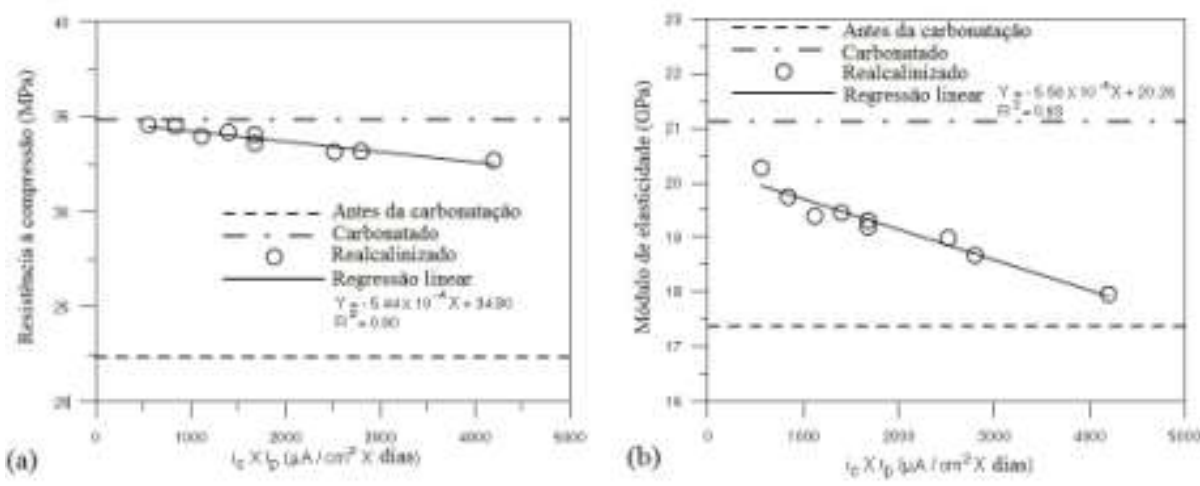

Figura 3.10. (a) Influência da quantidade de corrente aplicada durante a RAE na resistência à compressão. (b) Influência da quantidade de corrente aplicada durante a RAE no módulo de elasticidade (Yeih e Chang, 2005).

Com relação à realcalinização química, Teixeira (2002) registrou perda de resistência à compressão da ordem de 9\%, no qual os corpos-de-prova de referencia apresentaram uma resistência à compressão média de $18,74 \mathrm{MPa}$, e os realcalinizados de 17,04 MPa. Esta diferença, segundo o autor, é, provavelmente, devido aos novos produtos formados no interior da estrutura realcalinizada, sendo estes menos resistentes do que os produtos hidratados originais do concreto. No entanto, Araujo (2004) e Sá (2006) constataram que a realcalinização química, assim como nos estudos de realcalinização eletroquímica anteriormente citados, provocou um acréscimo nos valores de resistência à compressão. Sá (2006) para verificar se o acréscimo de 7,5\% na resistência à compressão do trabalho de Araujo (2004) era devido à formação de novos compostos químicos ou devido à hidratação dos compostos anidros do cimento durante a imersão dos mesmos nas soluções, tomou o cuidado de imergir os corpos-de-prova de referência em água durante a realcalinização dos corpos-de-prova carbonatados. Portanto, foi possível verificar que os corpos-de-prova realcalinizados ainda assim 
apresentaram um acréscimo na resistência à compressão em comparação com os corposde-prova de referência, que no estudo de Sá foi de 20\%. A Figura 3.11 apresenta os resultados de resistência à compressão dos trabalhos de Teixeira (2002), Araujo (2004) e Sá (2006), cujas concentrações das soluções foram detalhadas na Tabela 3.1.

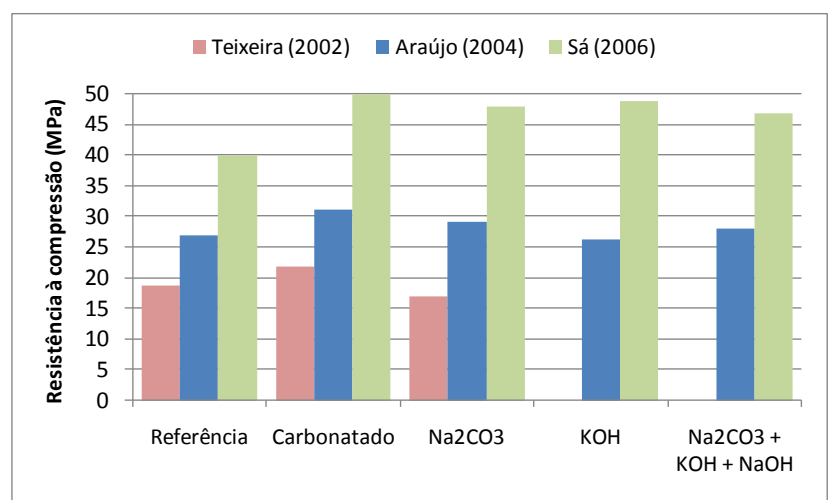

Figura 3.11. Resultados de resistência à compressão em corpos-de-prova de referência, carbonatados e realcalinizados.

Sá (2006) e Araujo (2004) utilizaram as mesmas soluções nas mesmas concentrações durante realcalinização, já Teixeira (2002) utilizou uma concentração maior da solução de carbonato de sódio (Tabela 3.1) e o traço da argamassa foi de 1,0:3,5:0,7 (cimento:areia:água). Embora o traço de argamassa de Sá (2006) fosse o mesmo de Araujo (2004), 1,0:3,0:0,5 (cimento:areia:água), houve uma diferença significativa nos valores de resistência à compressão em cada um dos sistemas estudados.

\subsection{Avaliação da EficiênCia da TéCNiCa de RealcalinizaÇão ELETROQUíMICA}

\subsubsection{INDICADOR QUÍMICO DE PH}

O procedimento de avaliação da eficiência da realcalinização pela aspersão de indicadores químicos de $\mathrm{pH}$ indica somente se o eletrólito dos poros do concreto está com valor de $\mathrm{pH}$ superior a 8,3, para a fenolftaleína, ou a 9,3, para a timolftaleína. No entanto, ambos os indicadores químicos não constatam o real valor do $\mathrm{pH}$ nos poros do concreto e não indicam a ocorrência ou não da repassivação da armadura. Desta maneira, outras formas de avaliação para verificação da eficácia do tratamento tornamse necessária. 
Assim, o critério mais comumente utilizado é a determinação da frente de realcalinização em um testemunho através da aspersão de indicadores químicos.

Um estudo abordado por Mietz (1998), foi o de Sergi et al. (1996) que desenvolveram uma técnica com dois estágios para verificar a eficácia do tratamento. No primeiro estágio, os autores aplicaram diferentes indicadores de $\mathrm{pH}$, com valores entre 10 e 13, na armadura e na superfície de amostras recém fraturadas de concretos de referência e realcalinizados. No segundo estágio, eles submeteram as armaduras à polarização anódica pelo galvanostato para descobrir o grau de repassivação das armaduras. Assim, os testes eletroquímicos nas armaduras, mostraram-se bastante eficientes nos vários estágios da realcalinização.

Ou seja, apenas a indicação colorimétrica fornecida pelo indicador de $\mathrm{pH}$ não dá subsídio suficiente para garantir a repassivação da armadura, informa apenas a faixa de $\mathrm{pH}$ no qual o concreto se encontra.

\subsubsection{MEdidAs ElETROQuímicAS}

Os critérios de aceitação para a finalização do tratamento de realcalinização eletroquímica ainda não estão consolidados em nenhuma norma regulamentadora. Alguns autores citados por Gonçalves et al. (2003), como Pollet (1990 e 2000) e Hondel e Polder (1998), classificam a quantidade de corrente aplicada na RAE como um bom critério, porém, há divergências com relação a isto, pois esta quantidade de corrente pode ser insuficiente para um determinado tipo de concreto.

A verificação da repassivação da armadura, mediante o uso de mapas de potencial ou de medidas de velocidade de corrosão utilizando a técnica de resistência de polarização, deve ser tomada como uma alternativa para avaliar a reconstituição da película de passivação na armadura. Neste caso, é necessário ressaltar a importância na análise cuidadosa dos resultados, já que inicialmente as armaduras encontram-se muito polarizadas, devido ao campo elétrico imposto, e a despolarização se dá lentamente. Portanto, os valores obtidos não devem ser interpretados da mesma forma que em uma estrutura não tratada (Gonçalves et al., 2005).

Outro estudo que analisou a eficácia da técnica através da polarização das armaduras foi o de Mietz et al. (1994), abordado em Mietz (1998). Neste, as amostras foram submetidas ao tratamento de realcalinização eletroquímica (polarização de 500 $\mathrm{mA} / \mathrm{m}^{2}$ ), durante 3 e 5 dias de tratamento. Nestas idades, os resultados obtidos indicaram a não ocorrência da repassivação, de acordo com os valores de densidade de 
corrente encontrados. No entanto, aos 7 dias de tratamento já foi possível esta verificação, uma vez que os valores de densidade de corrente encontrados mostraram-se insignificantes. Com estas mesmas amostras realcalinizadas eletroquimicamente, os pesquisadores utilizaram o indicador de fenolftaleína e constataram a formação de um anel de coloração vermelho-carmim ao redor da armadura, ou seja, indicando que as amostras estariam repassivadas.

Yeih e Chang (2005) também relacionaram a eficiência da realcalinização eletroquímica em concretos carbonatados à densidade de corrente aplicada e ao tempo de aplicação deste campo elétrico. Neste estudo, os corpos-de-prova carbonatados foram submetidos a diferentes densidades de correntes de 80,120 e $200 \mu \mathrm{A} / \mathrm{cm}^{2}$, durante 7,14 e 21 dias de tratamento. E como respostas foram avaliados os potenciais de corrosão e a taxa de corrosão para cada quantidade de corrente aplicada (Figura 3.12).
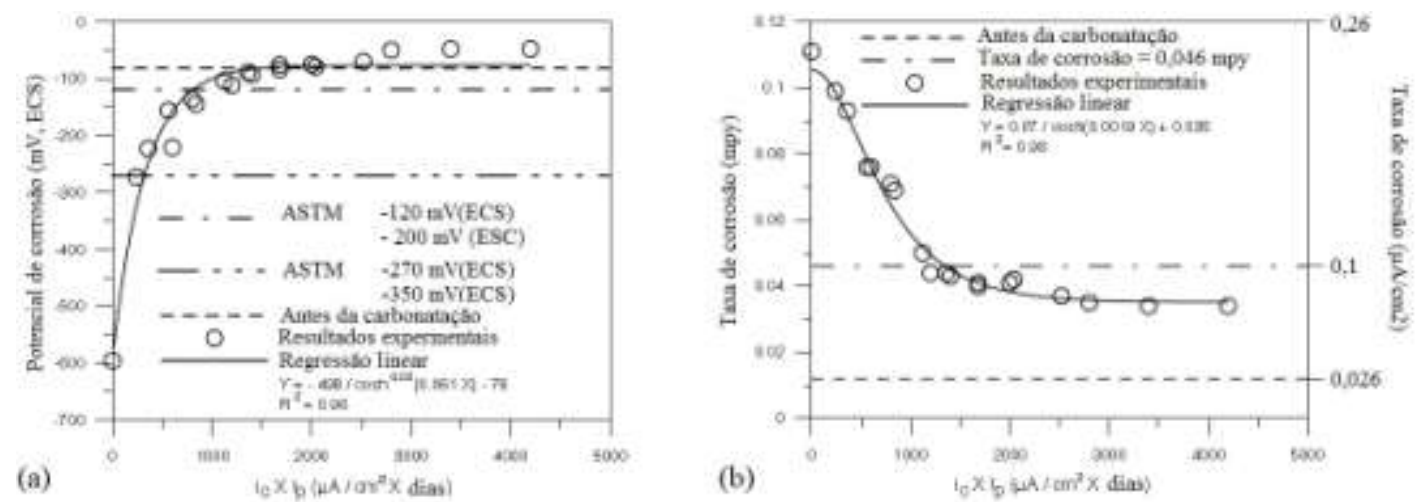

Figura 3.12. (a) Influência da quantidade de corrente aplicada durante a RAE no potencial de corrosão. (b) Influência da quantidade de corrente aplicada durante a RAE na taxa de corrosão (Yeih e Chang, 2005).

Quando a quantidade de corrente aplicada chegou a $807 \mu$ A.dias $/ \mathrm{cm}^{2}$, o potencial de corrosão obtido era de $-120 \mathrm{mV}$ com o eletrodo de calomelano saturado (ECS), ou seja, o corpo-de-prova já apresentava uma probabilidade de corrosão inferior a 5\%, conforme a ASTM-C876 (1991). Ao atingir $1460 \mu$ A.dias $/ \mathrm{cm}^{2}$, o corpo-de-prova apresentava o mesmo potencial de corrosão de antes da carbonatação do concreto (de referência), de $-82 \mathrm{mV}$ (ECS). Quando a quantidade de corrente aplicada atingiu $2400 \mu$ A.dias $/ \mathrm{cm}^{2}$, o potencial de corrosão era inferior ao potencial de referência, chegando a $-76 \mathrm{mV}$ (ECS).

Na Figura 3.12 (b) é possível observar que a taxa de corrosão, independente da quantidade de corrente aplicada, não se igualou à taxa de antes da carbonatação. No entanto, quando a densidade de corrente atingiu $1335 \mu$ A.dias $/ \mathrm{cm}^{2}$, a taxa de corrosão já 
era menor do que $0,046 \mathrm{mpy}$ ou $0,1 \mu \mathrm{A} / \mathrm{cm}^{2}$ (Yeih e Chang, 2005), tida como desprezível, de acordo com a recomendação da RILEM TC 154-EMC (RILEM, 2004).

González et al. (2000), também procurando verificar a eficácia da realcalinização eletroquímica, formulou uma metodologia que possibilitou analisar a repassivação da armadura suprimindo a variável referente ao aumento da resistividade ocasionada pela realcalinização. Primeiramente foram retiradas barras de ferro de estruturas com mais de 29 anos de vida útil, que apresentavam com o cobrimento destacado. Algumas dessas barras foram limpas e junto com as que não sofreram qualquer tipo de limpeza, ou seja, encontrava-se em um grau avançado de corrosão, foram realcalinizadas em dois sistemas diferentes: um consistia em imergir as barras diretamente em uma solução saturada de hidróxido de cálcio, e o outro em moldar um novo concreto de relação água/cimento 0,5 utilizando as barras.

Medidas constantes de intensidade de corrosão foram realizadas durante 70 dias, e ao final pôde-se constatar que as barras despassivadas, mas com baixo grau de corrosão, obtiveram êxito na repassivação. Por outro lado, as barras com alto grau de corrosão não obtiveram tal sucesso, estas barras continuaram com uma intensidade de corrosão bastante elevada independente do sistema analisado (Figura 3.13).
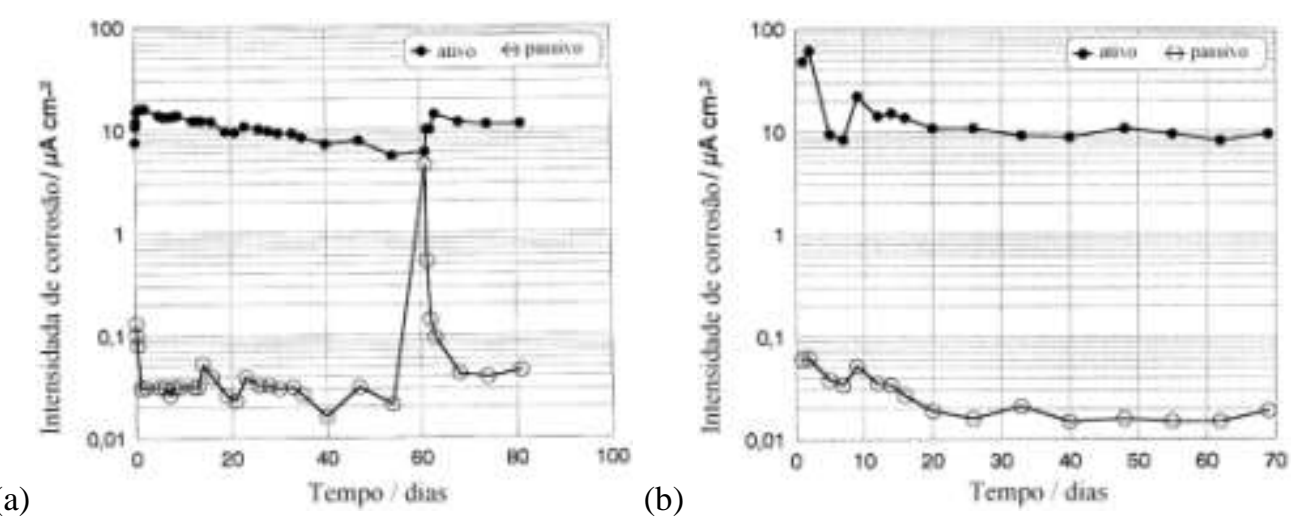

Figura 3.13. Comparação das barras com baixo (passivo) e alto grau (ativo) de corrosão para diversos tempos de realcalinização e a intensidade de corrosão em solução saturada de $\mathrm{Ca}(\mathrm{OH})_{2}$ (a), e em argamassa alcalina (b) (González et al., 2000).

Ao final do estudo, os autores concluíram que para armaduras despassivadas, mas com baixo grau de corrosão, a realcalinização era capaz de repassivar estas armaduras. Porém, os resultados em armaduras com alto grau de corrosão não apresentaram valores tidos como intensidade de corrosão desprezível $\left(<0,1 \mu \mathrm{A} / \mathrm{cm}^{2}\right)$, e questões sobre qual seria o grau de corrosão limite para a ocorrência da repassivação da armadura não conseguiram ser respondidas. 
Miranda et al. (2003) seguiram a mesma linha da pesquisa elaborada por González et al. (2000), porém, com o objetivo de responder justamente a pergunta em relação ao grau de corrosão limite para a RAE ser eficiente.

Desta maneira, a metodologia aplicada no estudo realizado por Miranda et al. (2003) consistiu em pré-corroer algumas barras, e assim classificar o grau de corrosão de cada uma delas. Para em seguida, imergi-las em uma solução saturada de hidróxido de cálcio proporcionando a realcalinização. Então, foram realizadas medidas periódicas de velocidade de corrosão para que fosse possível analisar em quais casos a repassivação ocorria de forma eficaz ou não.

Na Figura 3.14 fica clara a dificuldade das barras corroídas de voltarem ao estado passivo. As barras despassivadas, mas sem corrosão, conseguiram ficar na faixa tida como velocidade de corrosão desprezível $\left(<0,1 \mu \mathrm{A} / \mathrm{cm}^{2}\right)$, ou seja, foram repassivadas. Já as barras com até $280 \mathrm{mg} / \mathrm{dm}^{3}$ de ferro corroído conseguiram atingir velocidades de corrosão tidas como moderada (entre 0,1 e $0,5 \mu \mathrm{A} / \mathrm{cm}^{2}$ ). No entanto, as barras com $4300 \mathrm{mg} / \mathrm{dm}^{3}$ de ferro corroído não apresentaram nenhuma redução na velocidade de corrosão, mantendo-se na faixa de corrosão muito elevada (>1 $\left.\mu \mathrm{A} / \mathrm{cm}^{2}\right)$.

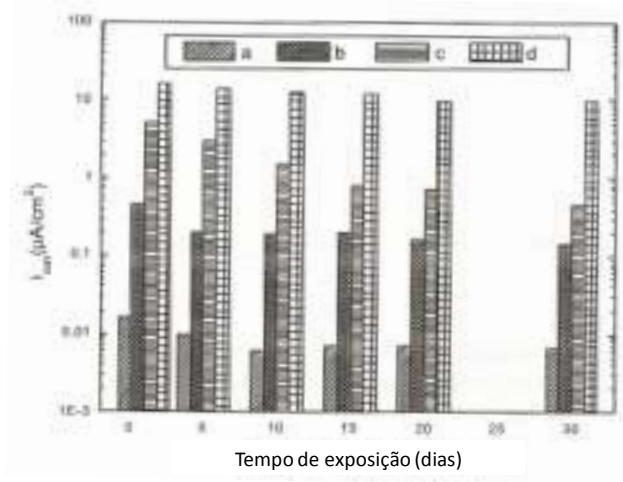

Figura 3.14. Comparação para diversos tempos de imersão em solução saturada de $\mathrm{Ca}(\mathrm{OH})_{2}$ e de velocidade de corrosão de barras com diferentes graus de pré-corrosão, onde: (a)0; (b) 145; (c) 280; e (d) $4300 \mathrm{mg} / \mathrm{dm}^{3}$ de ferro corroído (Miranda et al., 2003).

\subsection{DURABILIDADE Da REALCALINIZAÇÃo}

Acredita-se que a durabilidade do tratamento de realcalinização eletroquímica depende da qualidade da passivação. Ou seja, depende da estabilidade dos compostos formados através do eletrólito alcalino utilizado e, conseqüentemente, do $\mathrm{pH}$ final alcançado na fase aquosa dos poros do concreto. 
Hondel e Polder (1992), apud Mietz (1998), realizaram um acompanhamento do $\mathrm{pH}$ final alcançado pelas estruturas realcalinizadas eletroquimicamente. Os autores verificaram que, imediatamente depois de finalizado o tratamento, o pH encontrado foi próximo de 14. No entanto, depois de três ou quatro meses, verificou-se um decréscimo no valor de $\mathrm{pH}$ encontrado na mesma estrutura analisada inicialmente. Porém, os autores não informam para quanto este $\mathrm{pH}$ foi reduzido.

O mesmo efeito foi verificado por Kennedy et al. (1995), que ao utilizarem o carbonato de sódio como eletrólito durante a realcalinização, elevou, inicialmente, o $\mathrm{pH}$ da estrutura carbonatada a valores próximos a 11,5, mantendo-se um $\mathrm{pH}$ final estabilizado, em torno de 10,4.

Mietz (1998) explica que as reduções de concentração de álcalis no concreto realcalinizado, ou seja, a diminuição do valor de $\mathrm{pH}$, não são prejudiciais, pois se trata de uma reação normal de equilíbrio com as áreas não realcalinizadas.

$\mathrm{O}$ processo de redução do $\mathrm{pH}$ da estrutura realcalinizada depois de um período é devido ao fato da solução de carbonato de sódio introduzido já ser um carbonato, e esta solução reage, posteriormente, com o dióxido de carbono. Assim, o carbonato será convertido em bicarbonato de sódio $\left(\mathrm{NaHCO}_{3}\right)$, estabelecendo no concreto um pH de 10,4 (Kennedy et al., 1995).

Mattila et al. (1996), apud Mietz (1998), estudaram ensaios acelerados para verificar a lixiviação de álcalis por meio de medidas de concentração de sódio no interior da estrutura de concreto. Com base nessas medidas, foi constatado que a concentração de álcalis pode diminuir pela exposição intensa às intempéries. Inicialmente, o efeito de lixiviação afeta somente a zona próxima à superfície. Assim, a proteção contra a corrosão no concreto realcalinizado estará comprometida somente nas regiões de cobrimento menores do que $10 \mathrm{~mm}$, caso as estruturas estejam intensamente expostas às intempéries. Portanto, mesmo atingindo um $\mathrm{pH}$ favorável para a formação da película de passivação, é sempre recomendável a utilização de um revestimento de proteção apropriado e de alto desempenho sobre a superfície do concreto, para que a proteção obtida com a realcalinização seja mantida. Além disso, não se deve descartar a realização periódica de inspeções das estruturas reabilitadas através de medida de potencial e velocidade de corrosão, quando o revestimento aplicado permitir.

Elsener et al. (1998), citado por Mietz (1998), também recomendam o monitoramento da durabilidade da estrutura depois do tratamento através de medidas de 
potencial. Estes autores observaram potenciais de corrosão quase que constantes e homogêneos, mesmo depois de finalizado o tratamento a mais de um ano.

Odden (1994) também avaliou a eficiência da técnica de realcalinização eletroquímica durante os três primeiros anos após a finalização do tratamento. Os resultados obtidos indicaram que, através de mapas de potencial e de medidas de intensidade de corrosão, as estruturas encontravam-se fora da zona de probabilidade de corrosão em $100 \%$ das medidas realizadas.

Mandeno (1999), em um artigo publicado na revista Corrosion and Materials, afirma que uma vez revertida a carbonatação, através da realcalinização eletroquímica, a vida útil da estrutura poderia ser superior a 25 anos. No entanto, Gonçalves et al. (2003) afirmam que só foi possível avaliar estruturas com até 10 anos depois do tratamento, pois a técnica é relativamente recente. Porém, os autores ressaltam que ainda não existem registros de insucessos, definindo assim a vida útil da técnica.

Assim, como a durabilidade das estruturas realcalinizadas ainda é pouco conhecida, muitos estudos que abordam a técnica eletroquímica correlacionam os resultados obtidos ao final do tratamento com os resultados obtidos durante a manutenção destas estruturas, podendo prever de forma eficaz a vida útil de serviço da estrutura realcalinizada.

É importante ressaltar a questão da compatibilidade do sistema de revestimento aplicado com a nova superfície do concreto obtida pela realcalinização. Segundo Eggers e Oliveira (1997), caso seja adotado um sistema de pintura, este deve possuir boa resistência aos substratos alcalinos, pois, existem riscos da ocorrência de saponificação. Outros autores como Araujo et al. (2007c) sugerem a limpeza da estrutura realcalinizada com água sob pressão antes da realização da pintura de proteção superficial, a fim de remover as partículas oriundas das soluções empregadas na realcalinização, e que prejudicam a aderência das tintas e vernizes. 
O programa experimental desta pesquisa tem a finalidade de atender aos objetivos da mesma, ou seja, possibilitar a verificação da repassivação da armadura em concretos carbonatados, através da realcalinização química com diferentes tipos de soluções alcalinas.

A fim de complementar os resultados obtidos, esta pesquisa analisou outros fatores como a durabilidade da realcalinização química em condições de carbonatação aceleradas. As mudanças físicas da estrutura realcalinizada foram analisadas através dos os ensaios de absorção capilar e de imersão do concreto, e análise do pH do concreto realcalinizado por absorção e difusão com diferentes soluções alcalinas.

\subsection{Planejamento do Experimento}

Como planejamento do experimento tem-se a determinação das variáveis do trabalho, assim como a organização das atividades desenvolvidas durante a sua realização.

De acordo com Pereira (1996), as variáveis independentes, dependentes e intervenientes podem ser definidas da seguinte forma:

- Variáveis independentes são aquelas que afetam, influenciam ou determinam outras variáveis. Elas ocorrem antes das demais variáveis, manipulando os resultados para causar um efeito preestabelecido.

- Variáveis dependentes são aquelas afetadas ou explicadas pelas independentes, variando de acordo com as mudanças nas independentes. Consiste nos valores (fenômenos ou fatores) a serem explicados ou descobertos, em virtude de serem influenciados, determinados ou afetados pela variável independente. Ela aparece, desaparece ou varia à medida que o pesquisador introduz, tira ou modifica a variável independente; a propriedade ou fator que é efeito resultado, conseqüência ou resposta a algo que foi manipulado (variável independente).

- Variáveis intervenientes ou interventoras são aquelas que se encontram entre a independente e a dependente, tendo como função não apenas ampliar, diminuir ou anular a influência da variável independente sobre a dependente, mas como 
também ajudar a esclarecer a relação entre as variáveis independentes e dependentes.

Assim sendo, as variáveis do presente estudo se constituem conforme o descrito nos itens a seguir.

\subsubsection{VARIÁVEIS INDEPENDENTES}

As variáveis, que modificam o concreto e a realcalinização, estabelecidas nesta pesquisa estão descritas nos itens seguintes.

\subsubsection{CIMENTO PORTLAND}

O cimento Portland utilizado foi o tipo II-E, Classe 32, por ser este o cimento o mais utilizado na região de São Paulo.

\subsubsection{RELAÇÃo ÁGUA/CIMENTO}

Foram adotadas duas relações água/cimento (a/c) para a produção dos concretos utilizados nesta pesquisa. Uma teve como base o limite exigido pela norma brasileira "Projeto de estruturas de concreto - Procedimento" - NBR 6118 (ABNT, 2003) para realização de estruturas de concreto armado, de a/c 0,65. A outra foi baseada na realidade da grande maioria das obras brasileiras dos anos 80 e 90 que empregaram a/c=0,80, a qual está bem aquém da exigida atualmente pela NBR 6118 (ABNT, 2003).

\subsubsection{SOLUÇÕES ALCALINAS EMPREgAdAS NA REALCALINIZAÇÃO ELETROQUÍMICA E POR ABSORÇÃO E DIFUSÃO}

Os sais de carbonato de sódio, de hidróxido de potássio e de hidróxido de cálcio utilizados como eletrólito nas realcalinizações foram todos do tipo P.A. (puro para análise).

\subsubsection{VARIÁVEIS DEPENDENTES}

As variáveis de respostas referentes à esta tese são:

I. A verificação da repassivação da armadura através de medidas de potencial de corrosão (Ecorr) e de espectroscopia de impedância eletroquímica (EIE), nas técnicas de realcalinização eletroquímica e química; 
II. A velocidade e a profundidade da recarbonatação acelerada dos corpos-de-prova realcalinizados quimicamente por absorção e difusão com diferentes tipos de soluções alcalinas;

III. A absorção e ascensão capilar dos corpos-de-prova não carbonatados, carbonatados e realcalinizados quimicamente por absorção e difusão de soluções alcalinas.

As variáveis mencionadas permitem não somente uma discussão a respeito da técnica de realcalinização química por absorção e difusão de soluções alcalinas. Como também, permite a comparação das mesmas em relação à eficácia da repassivação da armadura.

\subsubsection{VARIÁVEIS INTERVENIENTES}

As variáveis entre as independentes e dependentes, são:

\subsubsection{CONDIÇÃO DE CURA}

Para tentar retratar, de forma adequada, a realidade dos concretos moldados nas obras foi definida duas idades de cura, de 1 dia e de 28 dias. A cura de 1 dia foi o período em que o concreto se encontrou ainda na fôrma coberto com o filme de PVC, representando a situação real dos concretos na maioria das obras. Os quais, em geral, depois de desmoldados não recebem mais nenhum cuidado com relação à cura. A outra cura seria até a idade de 28 dias, pois representaria os concretos já com a idade mais avançada, depois de 20 ou 30 anos.

\subsubsection{CONSUMO DE CIMENTO}

O consumo de cimento desta pesquisa foi de $301 \mathrm{~kg} / \mathrm{m}^{3}$ de concreto para a relação a/c igual a 0,65 , e de $265 \mathrm{~kg} / \mathrm{m}^{3}$ para a relação a/c igual a 0,80 (Tabela 4.1).

Tabela 4.1. Consumo de cimento dos concretos moldados para a realização dos ensaios da pesquisa.

\begin{tabular}{cc}
\hline Relação a/c & Consumo de cimento $\left(\mathbf{k g} / \mathbf{m}^{\mathbf{3}}\right)$ \\
\hline 0,65 & 301 \\
\hline 0,80 & 265 \\
\hline
\end{tabular}




\subsubsection{RESISTÊNCIA À COMPRESSÃO}

O ensaio de resistência à compressão foi realizado por meio do método de ensaios da NBR 5739, intitulado "Concreto - Ensaio de compressão de corpos-de-prova cilíndricos" (ABNT, 2007), sendo as fôrmas metálicas e de dimensão cilíndrica de 10x20. Para o concreto de relação água/cimento de 0,80 a resistência à compressão com 1 dia cura foi de 2,5 MPa e com 28 dias de cura foi de $21 \mathrm{MPa}$. Já o concreto de relação água/cimento de 0,65 teve a resistência de 5,8 MPa para a cura de 1 dia e 28,7 MPa para a cura de 28 dias (Tabela 4.2).

Tabela 4.2. Resistência à compressão dos concretos moldados nas idades de 1, 3, 7 e 28 dias.

\begin{tabular}{ccccc}
\hline \multirow{2}{*}{ Relação a/c } & \multicolumn{4}{c}{ Resistência à compressão média em MPa (idade) } \\
\cline { 2 - 5 } & $\mathbf{1 ~ d i a}$ & $\mathbf{3 ~ d i a s}$ & $\mathbf{7 ~ d i a s}$ & $\mathbf{2 8 ~ d i a s}$ \\
\hline 0,65 & 5,80 & 13,92 & 21,20 & 28,70 \\
\hline 0,80 & 2,50 & 9,90 & 13,70 & 21,00 \\
\hline
\end{tabular}

\subsubsection{ORGANIZAÇÃO DAS ATIVIDADES}

A moldagem, assim como todos os ensaios realizados nesta pesquisa, foi realizada no Centro de Pesquisa e Desenvolvimento em Construção Civil da Escola Politécnica/Universidade de São Paulo (CCpDCC-POLI/USP).

\subsubsection{DOSAGEM DO CONCRETO}

A dosagem dos concretos moldados foi realizada conforme o descrito no método do IBRACON (Helene e Terzian, 1995). Este método tem a finalidade de realizar um estudo de dosagem para definir os concretos de mesma família, ou seja, de mesmo teor de argamassa e abatimento.

No estudo de dosagem realizado, ficou definido que o teor de argamassa seria em torno de $52 \%$, de forma a garantir o envolvimento de todos os agregados pela argamassa, tomando o cuidado de não variar o abatimento de tronco de cone de $6 \pm$ $1 \mathrm{~cm}$ (Tabela 4.3).

Tabela 4.3. Características de dosagem dos concretos moldados, os quais a quantidade de material seco foi 4,6 e $8(\mathrm{~m}-2, \mathrm{~m}$ e $\mathrm{m}+2)$, com teor de argamassa de $52 \%$ e abatimento de $6 \pm 1 \mathrm{~cm}$.

\begin{tabular}{|c|c|c|c|c|c|c|c|c|c|}
\hline \multirow{2}{*}{$\begin{array}{c}\text { Relação } \\
\text { a/c }\end{array}$} & \multicolumn{4}{|c|}{ Traço unitário } & \multirow{2}{*}{$\begin{array}{c}\text { Consumo } \\
\text { de cimento } \\
\left(\mathrm{kg} / \mathrm{m}^{3}\right)\end{array}$} & \multicolumn{4}{|c|}{$\begin{array}{c}\text { Resistência à compressão média } \\
\text { em MPa (idade) }\end{array}$} \\
\hline & cimento & areia & brita & $\mathbf{m}$ & & 1 dia & 3 dias & 7 dias & 28 dias \\
\hline 0,46 & 1 & 1,60 & 2,40 & 4 & 433 & 11,70 & 24,32 & 37,50 & 45,17 \\
\hline 0,65 & 1 & 2,64 & 3,36 & 6 & 301 & 5,80 & 13,92 & 21,20 & 28,70 \\
\hline 0,93 & 1 & 3,68 & 4,32 & 8 & 225 & 2,25 & 6,75 & 11,20 & 16,15 \\
\hline
\end{tabular}


As Figuras 4.1, 4.2 e 4.3 mostram a aparência e os abatimentos dos concretos moldados para o estudo de dosagem realizado.

(a)

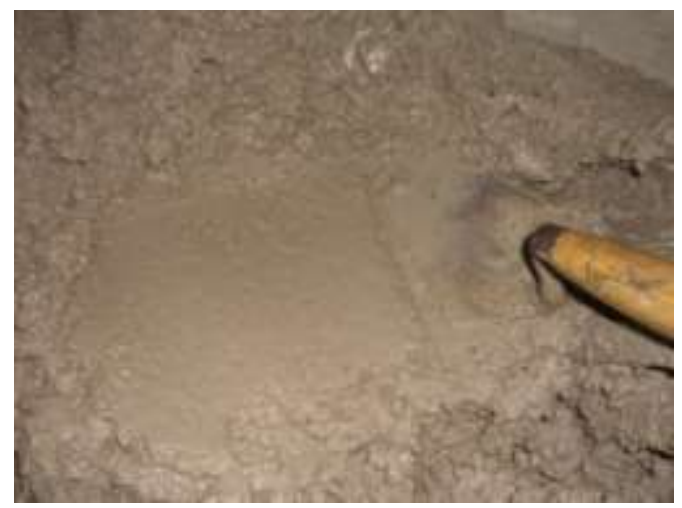

(b)

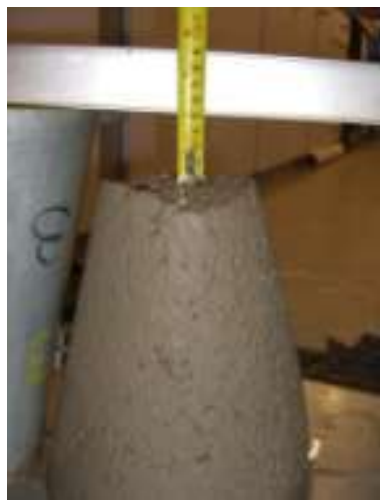

Figura 4.1. Concreto de relação a/c 0,46. (a) Aparência dos agregados devidamente envolvidos pela argamassa. (b) Abatimento de tronco de cone.

(a)

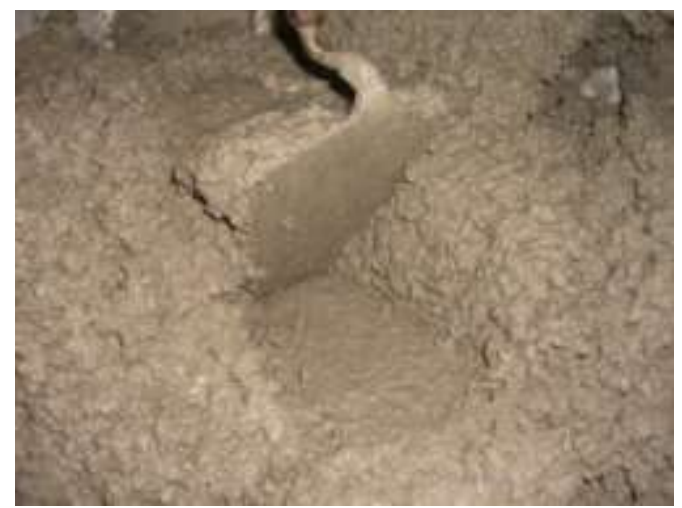

(b)

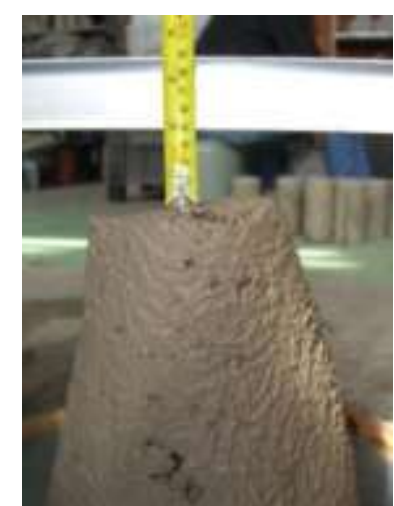

Figura 4.2. Concreto de relação a/c 0,65. (a) Aparência dos agregados devidamente envolvidos pela argamassa. (b) Abatimento de tronco de cone.

(a)

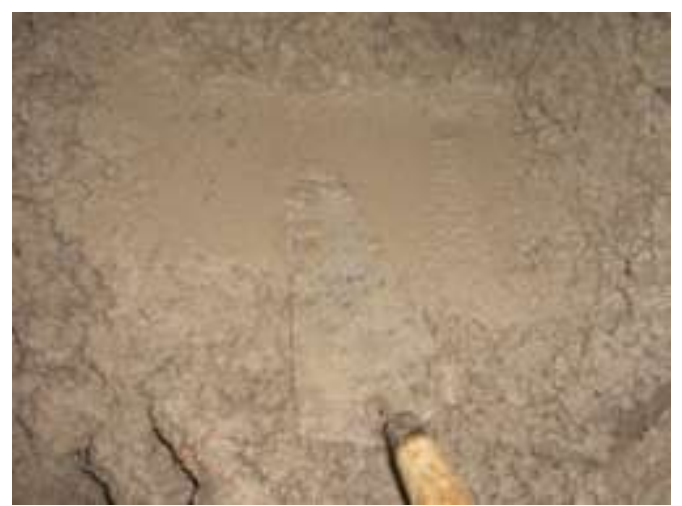

(b)

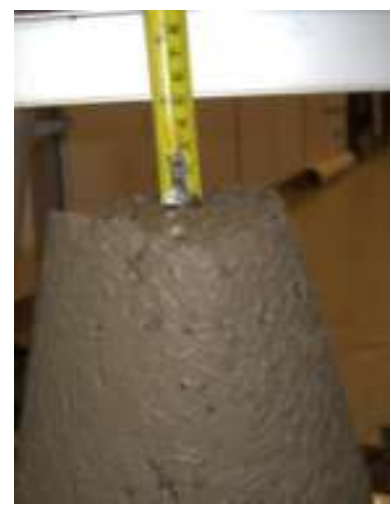

Figura 4.3. Concreto de relação a/c 0,93. (a) Aparência dos agregados devidamente envolvidos pela argamassa. (b) Abatimento de tronco de cone.

A partir dos dados da Tabela 4.3 foi possível desenvolver o diagrama de dosagem ilustrado na Figura 4.4. 


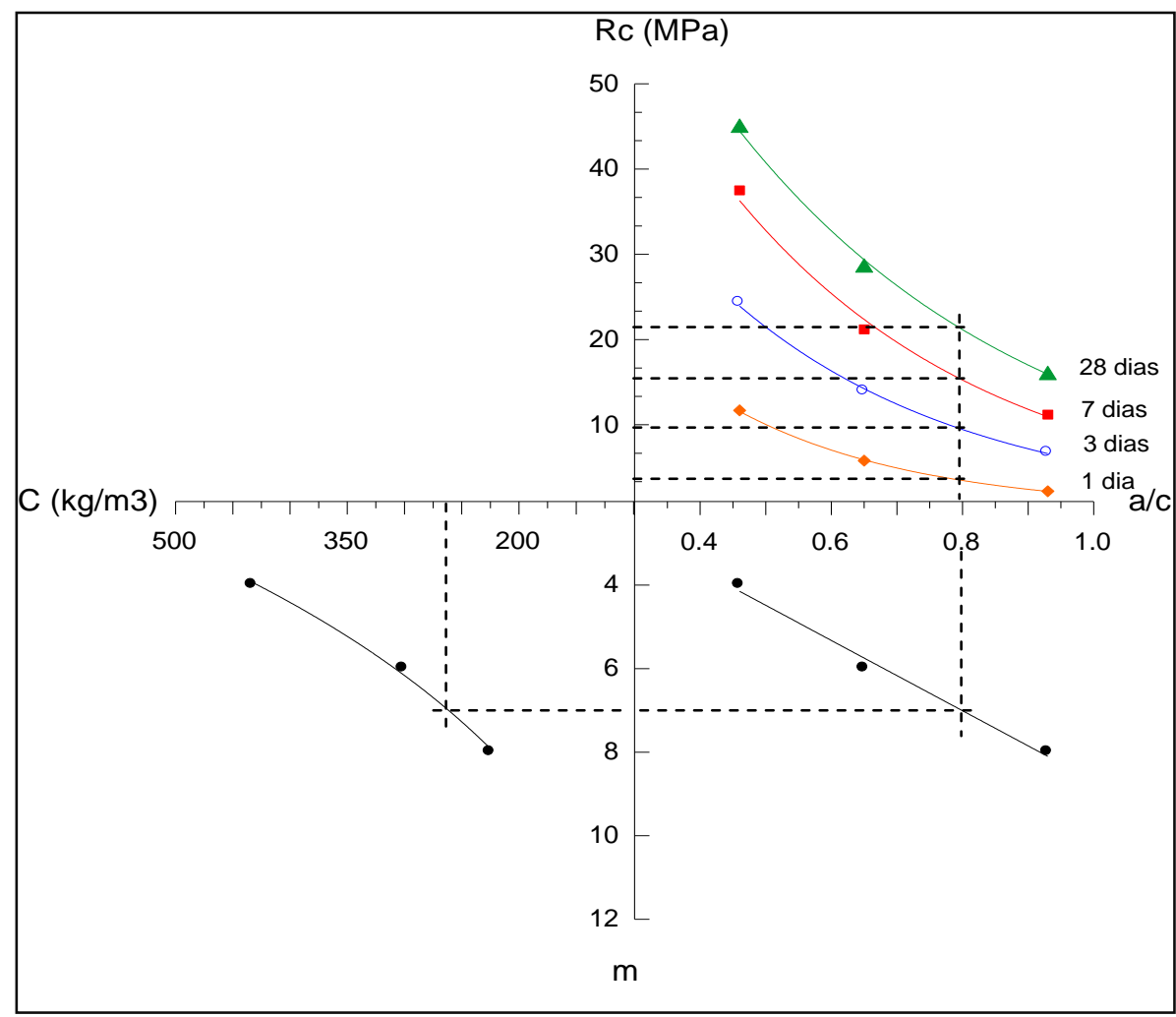

Figura 4.4. Diagrama de dosagem para concretos de abatimento de tronco de cone de $6 \pm 1 \mathrm{~cm}$ e teor de argamassa de $52 \%$.

E a partir das relações água/cimento pré-definidas, foi possível extrair do gráfico de dosagem da Figura 4.4 os dados necessários para a moldagem dos concretos com as relações a/c desejadas (Tabela 4.4).

Tabela 4.4. Traço unitário dos concretos moldados para a realização dos ensaios da pesquisa.

\begin{tabular}{ccccc}
\hline \multirow{2}{*}{ Relação a/c } & \multicolumn{5}{c}{ Traço unitário } \\
\cline { 2 - 5 } & cimento & areia & brita & m \\
\hline 0,65 & 1 & 2,64 & 3,36 & 6 \\
\hline 0,80 & 1 & 3,16 & 3,84 & 7 \\
\hline
\end{tabular}

\subsubsection{PREPARAÇÃO DOS CORPOS-DE-PROVA}

\section{a) ENSAIOS DE MEDIDAS ELETROQUÍMICAS}

Os corpos-de-prova foram prismáticos com dimensões de 12x12x4 cm, e no interior dos mesmos foram colocadas duas armaduras de aço carbono convencionais de diâmetro de $8 \mathrm{~mm}$, que revestidas com fita isolante resultavam em um diâmetro de $10 \mathrm{~mm}$. Após esta preparação, as barras apresentaram um trecho de $3 \mathrm{~cm}$ de comprimento sem fita isolante, de forma a delimitar a região da barra a ser despassivada. A colocação das duas barras em cada corpo-de-prova permitiu a 
realização de duas leituras em um mesmo corpo-de-prova, conforme ilustra a Figura 4.5 .

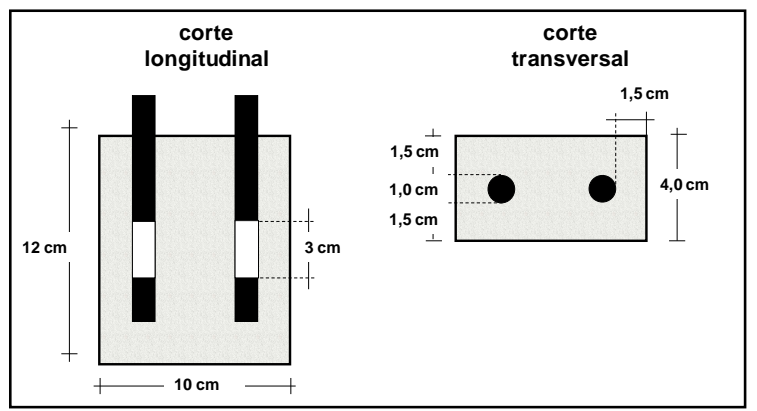

Figura 4.5. Modelo de corpo-de-prova para os ensaios eletroquímicos.

\section{a.1) PREPARACCÃO DAS ARMADURAS}

As barras de aço utilizadas nos corpos-de-prova dos ensaios de medidas eletroquímicas foram cortadas com o comprimento em torno de $16 \mathrm{~cm}$, e submetidas a um procedimento de limpeza específico (ASTM G1, 2003). A limpeza teve a finalidade de conferir à todas as barras as mesmas condições superficiais. Ou seja, limpas e livres de produtos de corrosão devido o seu armazenamento inadequado, procedimento importante, uma vez que serão utilizadas como sensores de corrosão nos ensaios. Depois de realizada a limpeza as mesmas foram revestidas com uma fita isolante de modo a delimitar a área de exposição da barra no interior dos corpos-de-prova.

O procedimento de limpeza empregado é baseado na norma americana ASTM G1 (2003). Esta norma prescreve a limpeza com a imersão das barras em uma solução de ácido clorídrico de 1:1 de água destilada, com 3,5 g/l de hexametilenotetramina. Ao completar os 15 minutos de imersão na solução (Figura 4.6), as barras foram enxaguadas em água corrente morna e com escova de cerdas de plástico para a remoção final dos óxidos e dos cloretos da solução ácida.

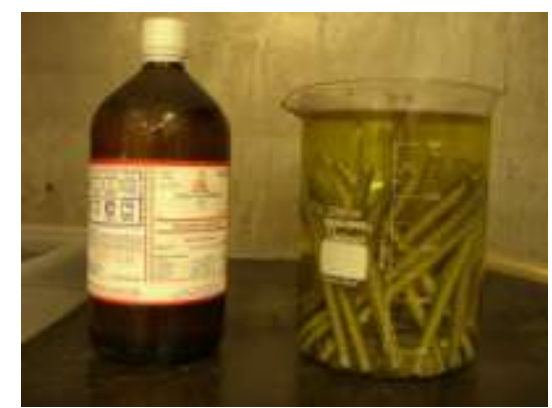

Figura 4.6. Limpeza das barras com imersão em solução de ácido clorídrico, água destilada e hexametilenotetramina.

As barras, após a escovação e enxágüe, permaneceram ainda imersas por 30 minutos em água quente, as quais a cada 15 minutos tiveram a água trocada. Este 
procedimento foi utilizado como forma de garantir a total remoção dos cloretos, que poderiam ter ficado nas barras devido à solução ácida,

Ao finalizar a limpeza, as barras foram imersas em acetona para retirar a água da sua superfície e secas com ar comprimido. No entanto, como a sua superfície ainda apresentava uma aparência encardida, em razão da oxidação atmosférica no momento de retirada das barras da água, foi realizado o polimento das barras em um esmeril de forma a retirar os óxidos formados na sua superfície. Ao terminar a fase de limpeza, as barras foram armazenadas em um dessecador com sílica gel até a sua utilização (Figura 4.7).

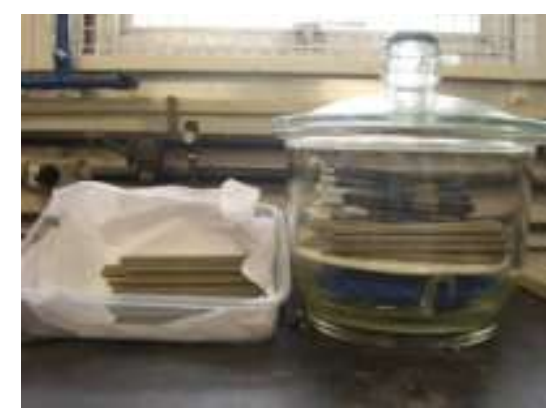

Figura 4.7. As barras após a secagem e armazenadas em um dessecador com sílica gel.

Este processo de polimento, devido à aparência de encardida da barra, poderia ter sido evitado se no momento de retirada das barras da acetona houvesse um jato de ar quente (um secador de cabelos, por exemplo) disponível para realizar a sua secagem e evitar a corrosão atmosférica.

$\mathrm{Na}$ véspera da moldagem, as barras tiveram o seu comprimento revestido com uma fita isolante. Sendo que duas regiões não foram revestidas com fita isolante. Uma região foi a extremidade da barra que ficou fora do corpo-de-prova, para que fosse possível conectar os equipamentos de medidas eletroquímicas. Esta região foi coberta com uma graxa condutora para evitar a sua oxidação durante a cura e a carbonatação acelerada. A outra região foi onde se desejava realizar a despassivação da armadura através da carbonatação, estabelecendo uma área em torno de $7,5 \mathrm{~cm}^{2}$ (Figura 4.8).

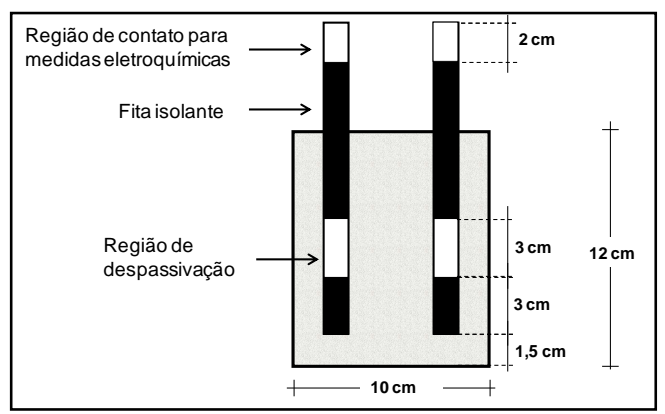

Figura 4.8. Esquema da delimitação da área a ser despassivada. 


\section{a.2) PREPARAÇ̃̃O DAS FÔRMAS}

As fôrmas produzidas para realização da moldagem dos corpos-de-prova prismáticos dos ensaios eletroquímicos foram de $\mathrm{PVC}$, de forma a não necessitar da aplicação de desmoldante na sua superfície. A fim de garantir o alinhamento das barras e, conseqüentemente, o seu cobrimento de $1,5 \mathrm{~cm}$ dos lados e no fundo do corpo-deprova, foram colocadas guias de diâmetro de $10 \mathrm{~mm}$, nas quais as barras eram fixadas (Figuras 4.9 e 4.10 ).

(a)

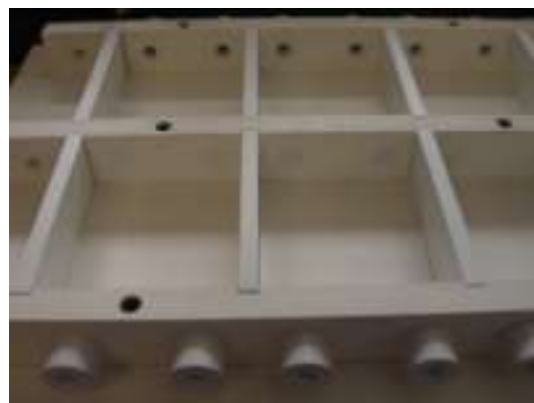

(b)

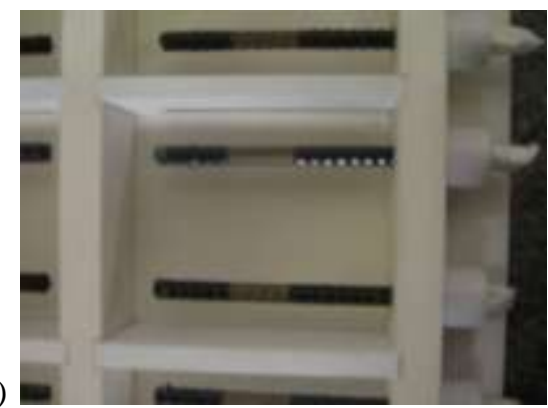

Figura 4.9. (a) Fôrma para moldagem dos corpos-de-prova dos ensaios de medidas eletroquímicas. (b) Detalhe das armaduras cobertas com fita isolante e alinhadas devido às guias.

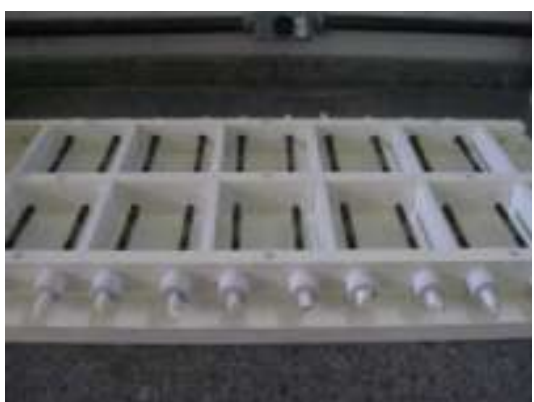

Figura 4.10. Fôrma montada e pronta para a realização da moldagem, com as armaduras revestidas com fita isolante e devidamente alinhadas através das guias.

Os corpos-de-prova assim que moldados foram adensados por 30 segundos em uma mesa vibratória e, em seguida, cobertos com um papel filme de forma a perder o mínimo possível de água para o ambiente (Figura 4.11) durante as primeiras 24 horas.

(a)

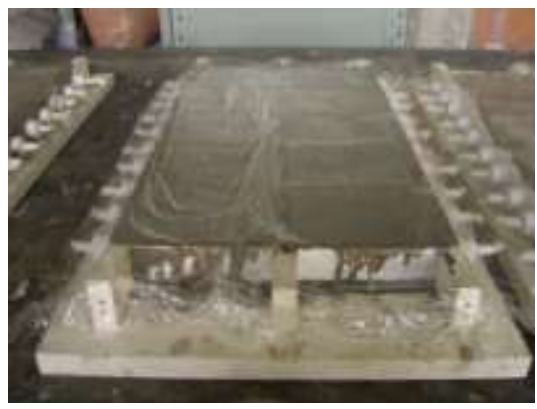

(b)

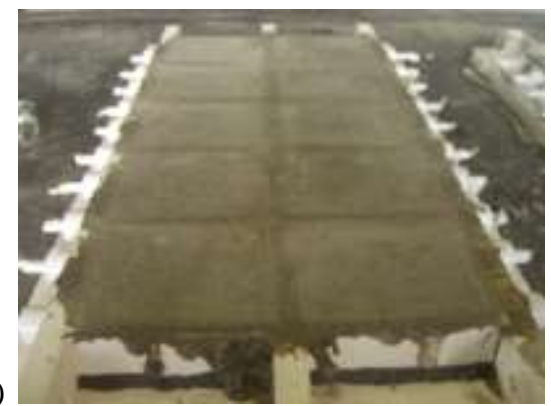

Figura 4.11. (a) Corpos-de-prova cobertos por papel filme para evitar perda de água para o ambiente. (b) Corpos-de-prova depois de 24 horas de moldagem. 
Passada as primeiras 24 horas da moldagem foi dado início à desmoldagem e à cura, abordada logo mais no item 4.1.4.3.

\section{b) ENSAIOS FÍSICOS}

Os ensaios físicos consistem nos ensaios de absorção capilar, absorção de água por imersão e de durabilidade da realcalinização química à recarbonatação do concreto tratado.

Os corpos-de-prova para os ensaios físicos foram moldados na mesma betonada dos corpos-de-prova destinados aos ensaios de medidas eletroquímicas e também adensados em uma mesa vibratória por 30 segundos. Porém, para os ensaios físicos foram adotados corpos-de-prova cilíndricos, com dimensões de $5 \times 10 \mathrm{~cm}$, sem armadura e moldados em fôrmas de aço.

Depois de finalizada a cura (item 4.1.4.3) e antes de iniciada a carbonatação acelerada (item 4.3.2), os corpos-de-prova foram serrados ao meio, e para possibilitar a realização da carbonatação acelerada em todos os corpos-de-prova desta pesquisa, conforme será abordado no item 4.3.4.

Durante a carbonatação e a realcalinização dos corpos-de-prova, alguns deles (chamados de referência ou não carbonatados) não foram colocados na câmara de carbonatação acelerada, ficando armazenados em caixas com a umidade controlada de $75 \pm 5 \%$, através da utilização de soluções com sais (ASTM E104, 2002). Para evitar a carbonatação dos corpos-de-prova de referência no interior das caixas, foram colocados potes com hidróxido de bário para absorver o $\mathrm{CO}_{2}$ do interior das mesmas. Estas caixas permaneceram em uma sala com a temperatura controlada de $23 \pm 3^{\circ} \mathrm{C}$ (Figura 4.12 ).
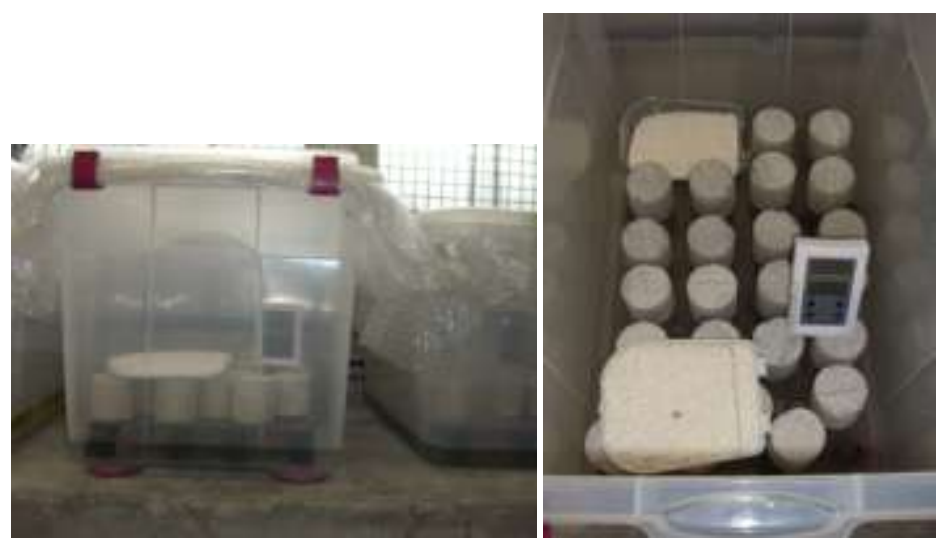

Figura 4.12. Caixa plástica com solução de NaCl saturado (ASTM E104, 2002) para controlar a umidade em $75 \pm 5 \%$, e recipiente de silicato de bário para evitar a carbonatação das amostras no interior das mesmas. 
A mesma metodologia descrita anteriormente para o armazenamento dos corpos-de-prova, com exceção da colocação dos potes com hidróxido de bário, foi realizada para os corpos-de-prova carbonatados que não seriam realcalinizados,

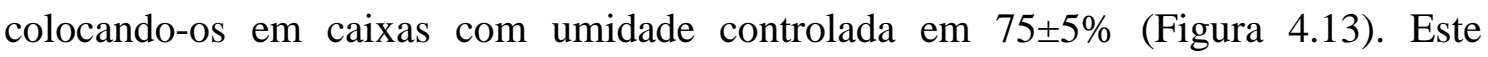
procedimento foi realizado de forma a garantir que os corpos-de-prova tivessem a mesma idade dos corpos-de-prova realcalinizados no momento dos ensaios físicos.

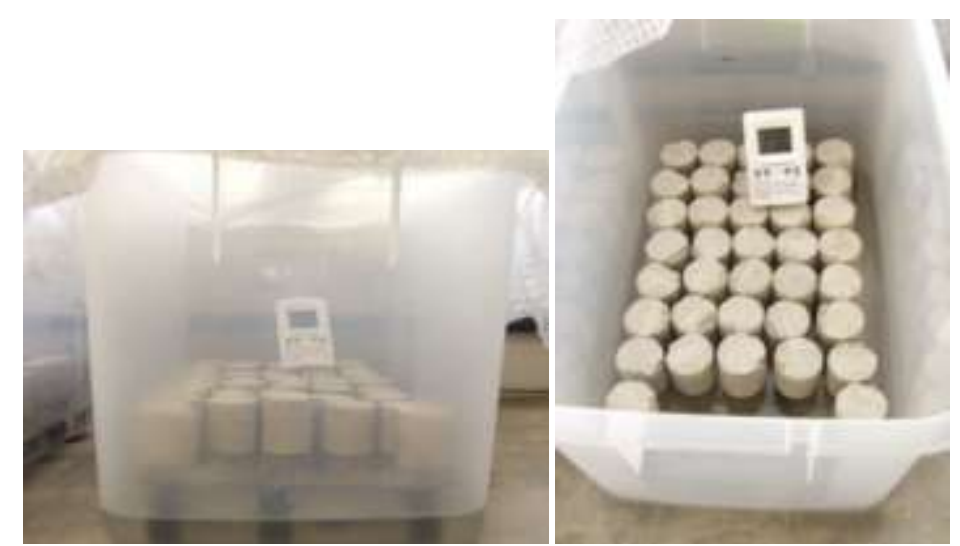

Figura 4.13. Corpos-de-prova carbonatados no interior de caixas plásticas para controlar a umidade em $75 \pm 5 \%$ no interior das mesmas.

Para realização dos ensaios físicos foi necessário aguardar a finalização da realcalinização nos corpos-de-prova carbonatados. Para então ser verificada a ocorrência ou não da colmatação dos poros na matriz realcalinizada através dos ensaios de absorção e imersão, e de durabilidade à recarbonatação do concreto realcalinizado.

\subsubsection{IDADE DE CURA DOS CORPOS-DE-PROVA}

Após a moldagem, todos os corpos-de-prova foram cobertos com papel filme de PVC, evitando a evaporação da água de amassamento da mistura para o meio ambiente, e desmoldados após 24 horas. As idades de cura dos corpos-de-prova foram de 1 dia e de 28 dias. A cura de 1 dia foi o período de 24 horas no qual o concreto se encontrou ainda na fôrma coberto com o filme de PVC. A cura de 28 dias foi realizada após a desmoldagem, que ocorreu depois de 24 horas, na qual os corpos-de-prova foram colocados na câmara úmida (a 100\% de umidade relativa) do CCpDCC-POLI/USP durante o período de 27 dias, completando assim os 28 dias de cura.

\subsubsection{NÚMERO DE CORPOS-DE-PROVA}

O número de corpos-de-prova foi definido inicialmente por especificações de normas, experiências de outros autores e por critérios estatísticos. O número de 
corpos-de-prova moldados e os ensaios aos quais foram destinados estão determinados da Tabela 4.5 à Tabela 4.7.

Na Tabela 4.5 é possível observar como ficou a distribuição dos corpos-deprova utilizados nos ensaios eletroquímicos. Cada corpo-de-prova forneceu duas medidas de leitura, pois cada um tinha duas barras imersas no concreto (Figura 4.5).

Tabela 4.5. Número de corpos-de-prova de concreto para os ensaios de medidas eletroquímicas (corpo-de-prova prismático 12x10x4,0 cm).

\begin{tabular}{|c|c|c|c|c|}
\hline $\begin{array}{c}\text { Relação } \\
\text { água/cimento }\end{array}$ & $\begin{array}{l}\text { Cura úmida } \\
\text { (dias) }\end{array}$ & $\begin{array}{c}\text { Tipo de } \\
\text { realcalinização }\end{array}$ & $\begin{array}{l}\text { Tipo de eletrólito } \\
\text { (solução alcalina) }\end{array}$ & $\begin{array}{c}\text { Número de corpos- } \\
\text { de-prova }\end{array}$ \\
\hline \multirow{16}{*}{$\mathrm{a} / \mathrm{c} 0,65$} & \multirow{8}{*}{ (2) } & \multirow{4}{*}{ Eletroquímica } & Solução $\mathrm{Na}_{2} \mathrm{CO}_{3}$ & 2 \\
\hline & & & Solução KOH & 2 \\
\hline & & & Solução $\mathrm{Ca}(\mathrm{OH})_{2}$ & 2 \\
\hline & & & Irmão (referência) & 1 \\
\hline & & \multirow{4}{*}{ Química } & Solução $\mathrm{Na}_{2} \mathrm{CO}_{3}$ & 2 \\
\hline & & & Solução KOH & 2 \\
\hline & & & Solução $\mathrm{Ca}(\mathrm{OH})_{2}$ & 2 \\
\hline & & & Irmão (referência) & 1 \\
\hline & \multirow{8}{*}{28} & \multirow{4}{*}{ Eletroquímica } & Solução $\mathrm{Na}_{2} \mathrm{CO}_{3}$ & 2 \\
\hline & & & Solução KOH & 2 \\
\hline & & & Solução $\mathrm{Ca}(\mathrm{OH})_{2}$ & 2 \\
\hline & & & Irmão (referência) & 1 \\
\hline & & \multirow{4}{*}{ Química } & Solução $\mathrm{Na}_{2} \mathrm{CO}_{3}$ & 2 \\
\hline & & & Solução KOH & 2 \\
\hline & & & Solução $\mathrm{Ca}(\mathrm{OH})_{2}$ & 2 \\
\hline & & & Irmão (referência) & 1 \\
\hline \multirow{17}{*}{$\mathrm{a} / \mathrm{c} 0,80$} & \multirow{8}{*}{1} & \multirow{4}{*}{ Eletroquímica } & Solução $\mathrm{Na}_{2} \mathrm{CO}_{3}$ & 2 \\
\hline & & & Solução KOH & 2 \\
\hline & & & Solução $\mathrm{Ca}(\mathrm{OH})_{2}$ & 2 \\
\hline & & & Irmão (referência) & 1 \\
\hline & & \multirow{4}{*}{ Química } & Solução $\mathrm{Na}_{2} \mathrm{CO}_{3}$ & 2 \\
\hline & & & Solução KOH & 2 \\
\hline & & & Solução $\mathrm{Ca}(\mathrm{OH})_{2}$ & 2 \\
\hline & & & Irmão (referência) & 1 \\
\hline & \multirow{8}{*}{28} & \multirow{4}{*}{ Eletroquímica } & Solução $\mathrm{Na}_{2} \mathrm{CO}_{3}$ & 2 \\
\hline & & & Solução KOH & 2 \\
\hline & & & Solução $\mathrm{Ca}(\mathrm{OH})_{2}$ & 2 \\
\hline & & & Irmão (referência) & 1 \\
\hline & & \multirow{4}{*}{ Química } & Solução $\mathrm{Na}_{2} \mathrm{CO}_{3}$ & 2 \\
\hline & & & Solução KOH & 2 \\
\hline & & & Solução $\mathrm{Ca}(\mathrm{OH})_{2}$ & 2 \\
\hline & & & Irmão (referência) & 1 \\
\hline & \multicolumn{2}{|c|}{ Total } & & 56 \\
\hline
\end{tabular}

Na Tabela 4.6 e na Tabela 4.7 está definida a amostragem dos corpos-deprova utilizados nos ensaios físicos por situação de ensaio: não carbonatado, carbonatado e realcalinizado com as soluções de $\mathrm{Na}_{2} \mathrm{CO}_{3}$, de $\mathrm{KOH}$ e de $\mathrm{Ca}(\mathrm{OH})_{2}$. 
Tabela 4.6. Número de corpos-de-prova de concreto para o ensaio de absorção capilar e imersão (corpo-de-prova cilíndrico de $5 \times 5 \mathrm{~cm}$ ).

\begin{tabular}{|c|c|c|c|c|c|c|c|c|c|c|c|c|c|}
\hline \multirow{3}{*}{ Ensaio } & \multicolumn{6}{|c|}{$\begin{array}{c}\mathrm{a} / \mathrm{c}=0,65 \\
\text { Cura úmida (dias) }\end{array}$} & \multicolumn{6}{|c|}{$\begin{array}{c}\mathrm{a} / \mathrm{c}=\mathbf{0 , 8 0} \\
\text { Cura úmida (dias) }\end{array}$} & \multirow{3}{*}{$\begin{array}{c}\text { Total de } \\
\text { corpos-de- } \\
\text { prova }\end{array}$} \\
\hline & \multicolumn{3}{|c|}{1} & \multicolumn{3}{|c|}{28} & \multicolumn{3}{|c|}{1} & \multicolumn{3}{|c|}{28} & \\
\hline & $\mathbf{N}$ & $\mathbf{C}$ & $\mathbf{R}$ & $\mathbf{N}$ & $\mathbf{C}$ & $\mathbf{R}$ & $\mathbf{N}$ & $\mathbf{C}$ & $\mathbf{R}$ & $\mathbf{N}$ & $\mathbf{C}$ & $\mathbf{R}$ & \\
\hline Absorção por capilaridade & 2 & 2 & 9 & 2 & 2 & 9 & 2 & 2 & 9 & 2 & 2 & 9 & 52 \\
\hline Absorção por imersão & 1 & 2 & 6 & 1 & 2 & 6 & 1 & 2 & 6 & 1 & 2 & 6 & 36 \\
\hline Corpo-de-prova "irmão" & - & 2 & 5 & - & 2 & 5 & - & 2 & 5 & - & 2 & 5 & 28 \\
\hline Total & \multicolumn{6}{|c|}{58} & \multicolumn{6}{|c|}{58} & 116 \\
\hline
\end{tabular}

*N (não carbonatado); C (carbonatado); R (Realcalinizado)

Tabela 4.7. Número de corpos-de-prova de concreto para o ensaio de durabilidade da realcalinização química - RAQ (corpo-de-prova cilíndrico de $5 \times 5 \mathrm{~cm}$ ).

\begin{tabular}{|c|c|c|c|c|c|c|c|c|c|}
\hline \multirow{3}{*}{ Ensaio } & \multicolumn{4}{|c|}{$\begin{array}{c}a / c=0,65 \\
\text { Cura úmida (dias) }\end{array}$} & \multicolumn{4}{|c|}{$\begin{array}{c}\mathrm{a} / \mathrm{c}=\mathbf{0 , 8 0} \\
\text { Cura úmida (dias) }\end{array}$} & \multirow{3}{*}{$\begin{array}{c}\text { Total de } \\
\text { corpos-de- } \\
\text { prova }\end{array}$} \\
\hline & \multicolumn{2}{|c|}{1} & \multicolumn{2}{|c|}{28} & \multicolumn{2}{|c|}{1} & \multicolumn{2}{|c|}{28} & \\
\hline & $\mathbf{N}$ & $\mathbf{R}$ & $\mathbf{N}$ & $\mathbf{R}$ & $\mathbf{N}$ & $\mathbf{R}$ & $\mathbf{N}$ & $\mathbf{R}$ & \\
\hline Durabilidade da RAQ & 2 & 6 & 2 & 6 & 2 & 6 & 2 & 6 & 32 \\
\hline Corpo-de-prova "irmão" & 1 & 6 & 1 & 6 & 1 & 6 & 1 & 6 & 28 \\
\hline Total & \multicolumn{4}{|c|}{30} & \multicolumn{4}{|c|}{30} & 60 \\
\hline
\end{tabular}

*N (não carbonatado); R (Realcalinizado)

A Figura 4.14 e a Figura 4.15 expõem de forma clara o fluxograma dos ensaios eletroquímicos e físicos realizados durante a pesquisa.

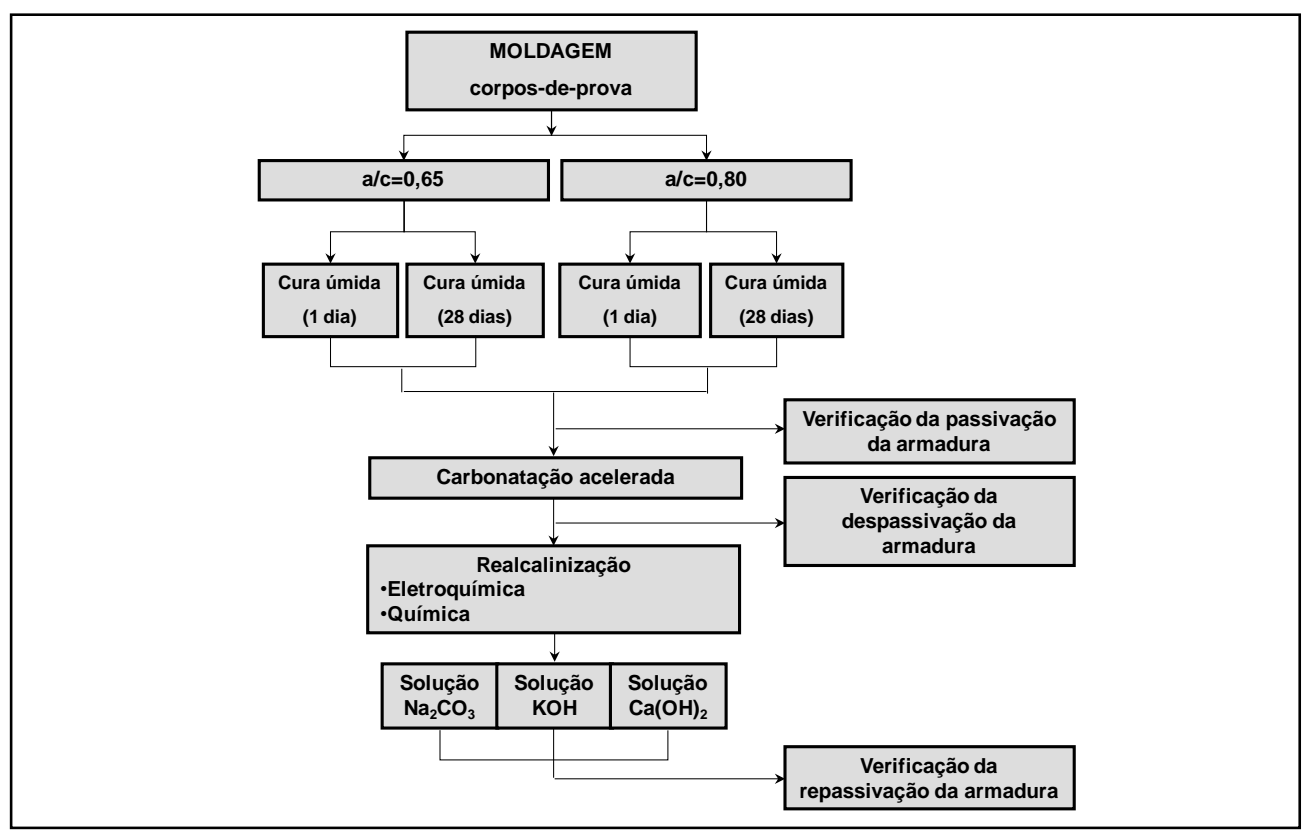

Figura 4.14. Fluxograma dos ensaios eletroquímicos realizados nesta pesquisa. 


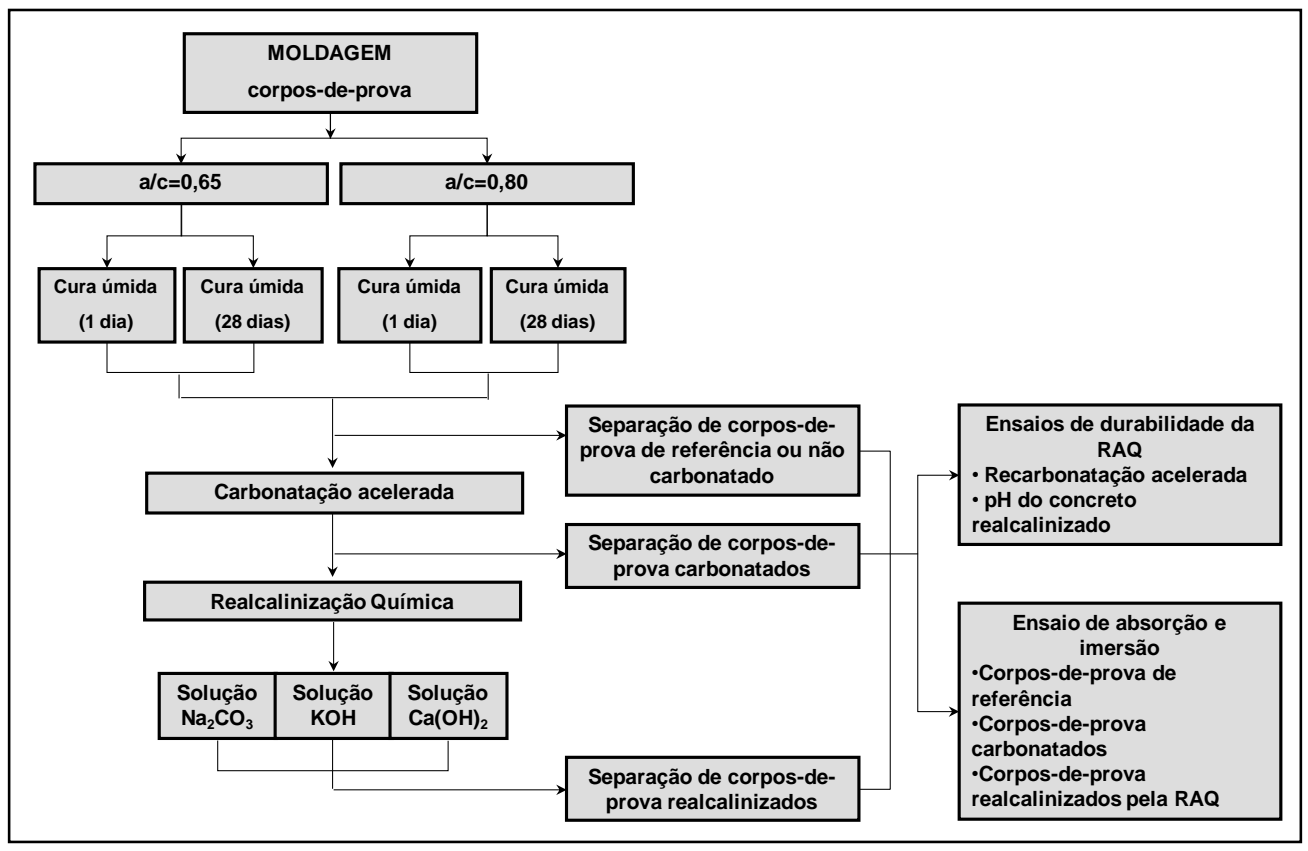

Figura 4.15. Fluxograma dos ensaios físicos realizados nesta pesquisa.

\subsection{MATERIAIS}

\subsubsection{Cimento PORTLAND}

A caracterização das propriedades físicas (Tabela 4.8 e Tabela 4.9) e químicas (Tabela 4.10) do cimento Portland tipo II-E, Classe 32, utilizado nesta pesquisa, foi realizada no Laboratório do Instituto de Pesquisa e Tecnologia de São Paulo (IPT). Em todos os ensaios realizados os limites foram dados pela NBR 11578 (ABNT, 1991).

Tabela 4.8. Propriedades físicas do cimento CP II E-32.

\begin{tabular}{lccc}
\hline \multicolumn{1}{c}{ Ensaio } & Norma (NBR) & Valor & Limite \\
\hline Finura - resíduo na peneira de 0,075 mm (\%) & $11579 / 91$ & 0,3 & $\leq 12,0$ \\
\hline Água para pasta norma (\% massa do cimento) & NM 43/03 & 28,5 & - \\
\hline Início de pega (h:min) & NM 65/03 & $3: 25$ & $\geq 60$ min $(01 \mathrm{~h})$ \\
\hline Fim de pega (h:min) & NM 65/03 & $4: 45$ & $\leq 600$ min $(10 \mathrm{~h})$ \\
\hline Expansibilidade - Frio (mm) & $11582 / 91$ & 0,5 & $\leq 5,0$ \\
\hline Expansibilidade - Quente $(5 \mathrm{~h})(\mathrm{mm})$ & $11582 / 91$ & 0,0 & $\leq 5,0$ \\
\hline Massa específica $\left(\mathrm{g} / \mathrm{cm}^{2}\right)$ & $\mathrm{NM} \mathrm{23/01}$ & 3,00 & - \\
\hline Finura - método Blaine $\left(\mathrm{cm}^{2} / \mathrm{g}\right)$ & $\mathrm{NM} \mathrm{76/98}$ & 4660 & - \\
\hline Finura - método Blaine $\left(\mathrm{m}^{2} / \mathrm{kg}\right)$ & $\mathrm{NM} \mathrm{76/98}$ & 466 & $\geq 260,0$ \\
\hline
\end{tabular}


Tabela 4.9. Propriedades de resistência à compressão, em MPa, do cimento CP II E-32, ensaiado conforme a prescrição da NBR 7215 (ABNT, 1996).

\begin{tabular}{|c|c|c|c|c|c|c|c|}
\hline \multirow{2}{*}{ Idade (dias) } & \multicolumn{4}{|c|}{ Corpo-de-prova $\left(n^{\circ}.\right)$} & \multirow{2}{*}{ Média } & \multirow{2}{*}{$\begin{array}{c}\text { DRM }^{3} \\
(\%)\end{array}$} & \multirow{2}{*}{ Limite } \\
\hline & 1 & 2 & 3 & 4 & & & \\
\hline 3 & 21,4 & 21,8 & 22,3 & 22,0 & 21,9 & 2,3 & $\geq 10,0 \mathrm{MPa}$ \\
\hline 7 & 31,5 & 30,3 & 31,6 & 30,8 & 31,1 & 2,6 & $\geq 20,0 \mathrm{MPa}$ \\
\hline 28 & 39,8 & 39,2 & 39,0 & 39,0 & 39,3 & 1,3 & $\geq 32,0 \mathrm{MPa}$ \\
\hline
\end{tabular}

Tabela 4.10. Resultado das propriedades químicas do cimento utilizado.

\begin{tabular}{lccc}
\hline \multicolumn{1}{c}{ Ensaio } & Norma (NBR) & Resultado (\%) & Limite (\%) \\
\hline Perda ao fogo $(\mathrm{PF})$ & $\mathrm{NM} \mathrm{18/04}$ & 5,14 & $\leq 6,5$ \\
\hline Anidrido silícico $\left(\mathrm{SiO}_{2}\right)$ & $\mathrm{NM} \mathrm{11-2/04}$ & 24,3 & - \\
\hline Óxido de alumínio $\left(\mathrm{Al}_{2} \mathrm{O}_{3}\right)$ & $\mathrm{NM} \mathrm{11-2/04}$ & 7,47 & - \\
\hline Óxido férrico $\left(\mathrm{Fe}_{2} \mathrm{O}_{3}\right)$ & $\mathrm{NM} \mathrm{11-2/04}$ & 2,16 & - \\
\hline Óxido de cálcio $(\mathrm{CaO})$ & $\mathrm{NM} \mathrm{11-2/04}$ & 55,8 & - \\
\hline Óxido de magnésio $(\mathrm{MgO})$ & $\mathrm{NM} \mathrm{11-2/04}$ & 2,77 & $\leq 6,5$ \\
\hline Anidrido sulfúrico $\left(\mathrm{SO}_{3}\right)$ & $\mathrm{NM} \mathrm{16/04}$ & 1,49 & $\leq 4,0$ \\
\hline Óxido de sódio $\left(\mathrm{Na}_{2} \mathrm{O}\right)$ & $\mathrm{NM} \mathrm{17/04}$ & 0,21 & - \\
\hline Óxido de potássio $\left(\mathrm{K}_{2} \mathrm{O}\right)$ & $\mathrm{NM} \mathrm{17/04}$ & 0,55 & - \\
\hline Equivalente alcalino $\left.(\mathrm{em} \mathrm{Na})_{2} \mathrm{O}\right)^{4}$ & - & 0,57 & - \\
\hline Sulfeto $\left(\mathrm{S}^{2-}\right)$ & $\mathrm{NM} \mathrm{19/04}$ & 0,33 & - \\
\hline Óxido de cálcio livre $(\mathrm{CaO})$ & $\mathrm{NM} \mathrm{13/04}$ & 1,12 & $\leq 2,5$ \\
\hline Resíduo insolúvel $(\mathrm{RI})$ & $\mathrm{NM} \mathrm{15/04}$ & 2,00 & $\leq 5,0$ \\
\hline Anidrido carbônico $\left(\mathrm{CO}_{2}\right)$ & $\mathrm{NM} \mathrm{20/04}$ & 4,08 & - \\
\hline
\end{tabular}

\subsubsection{Agregados MiÚdo E Graúdo}

O agregado miúdo utilizado nesta pesquisa foi uma areia rosa lavada de rio, cujas características físicas e de granulometria foram obtidas através de ensaios realizados no IPT, e encontram-se na Tabela 4.11 e na Figura 4.16, respectivamente.

Tabela 4.11. Resultado das propriedades físicas do agregado miúdo.

\begin{tabular}{lll}
\hline Ensaio & Norma (ABNT) & Resultado \\
\hline Massa específica $\left(\mathrm{g} / \mathrm{cm}^{3}\right)$ & NBR $9776 / 87$ & 2,62 \\
\hline Massa unitária em estado solto $\left(\mathrm{g} / \mathrm{cm}^{3}\right)$ & NBR $7251 / 82$ & 1,40 \\
\hline Massa unitária em estado compactado $\left(\mathrm{g} / \mathrm{cm}^{3}\right)$ & NBR $7810 / 83$ & 1,57 \\
\hline Absorção de água $(\%)$ & NBR $9777 / 87$ & 0,29 \\
\hline Teor de argila em torrões & NBR 7218/87 & 0,58 \\
\hline Teor de material pulverulento $(\%)$ & NBR $7219 / 87$ & 0,8 \\
\hline Coeficiente de inchamento $(\%)$ & NBR $6467 / 87$ & 1,36 \\
\hline Índice de matéria orgânica & NBR 7220/87 & $\begin{array}{l}\text { Menos escura do que a } \\
\text { solução padrão }\end{array}$ \\
\hline Dimensão máxima do agregado $(\mathrm{mm})$ & NBR 7217/87 & 2,4 \\
\hline Módulo de finura & NBR 7217/87 & 2,22 \\
\hline & &
\end{tabular}

\footnotetext{
${ }^{3}$ DRM: Desvio Relativo Médio.

${ }^{4}$ Equivalente alcalino $\left(e m \mathrm{Na}_{2} \mathrm{O}\right)=\% \mathrm{Na}_{2} \mathrm{O}+0,658 \times \% \mathrm{~K}_{2} \mathrm{O}$. Calculado a partir das diretrizes gerais da ASTM C110/06.
} 


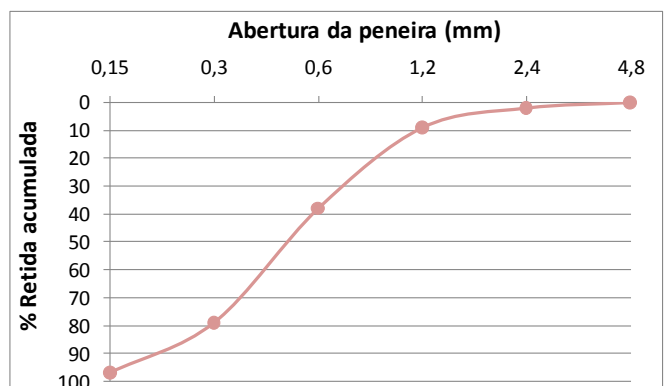

Figura 4.16. Gráfico da composição granulométrica do agregado miúdo.

De acordo com os resultados de granulometria ilustrados na Figura 4.16 e a norma NBR 7211 (ABNT, 1983) esta areia enquadra-se na zona 2, classificada como fina.

O agregado graúdo utilizado foi uma brita granítica, também conhecida como pedrisco, cujas propriedades físicas e análise granulométrica encontram-se na Tabela 4.12 e na Figura 4.17, respectivamente. Este material também teve seus ensaios realizados pelo laboratório do IPT.

Tabela 4.12. Resultado das propriedades físicas do agregado graúdo.

\begin{tabular}{llc}
\hline \multicolumn{1}{c}{ Ensaio } & Norma $(\mathrm{ABNT})$ & Resultado \\
\hline Massa específica saturada superfície seca $\left(\mathrm{g} / \mathrm{cm}^{3}\right)$ & NBR-NM-53/03 & 2,68 \\
\hline Massa específica seca $\left(\mathrm{g} / \mathrm{cm}^{3}\right)$ & NBR-NM-53/03 & 2,70 \\
\hline Massa unitária $\left(\mathrm{kg} / \mathrm{dm}^{3}\right)$ & NBR-7251/82 & 1,84 \\
\hline Absorção de água $(\%)$ & NBR-NM-53/03 & 0,50 \\
\hline Teor de argila & NBR-7218/87 & ausente \\
\hline Teor de material pulverulento $(\%)$ & NBR-7219/87 & 0,10 \\
\hline Dimensão máxima do agregado $(\mathrm{mm})$ & NBR 7217/87 & 9,50 \\
\hline Módulo de finura & NBR 7217/87 & 1,86 \\
\hline
\end{tabular}

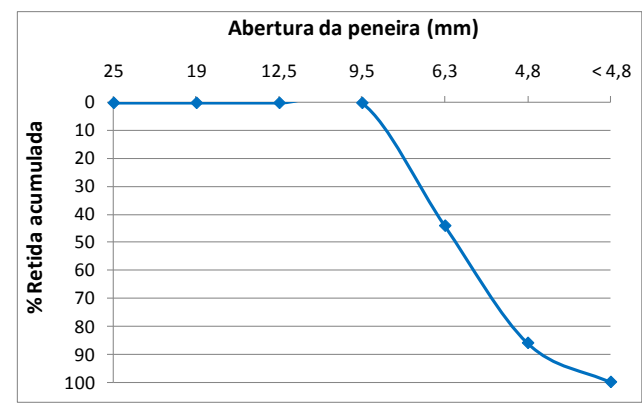

Figura 4.17. Gráfico da composição granulométrica do agregado graúdo.

Esta brita é classificada como brita zero, segundo a norma NBR 7211 (ABNT, 1983).

A brita tipo zero foi escolhida para garantir que os corpos-de-prova moldados para o ensaio de medidas eletroquímicas estivessem conforme o exigido pela norma NBR 6118 da Associação Brasileira de Normas Técnicas (ABNT, 2003). Na 
qual a dimensão máxima característica do agregado graúdo utilizado no concreto, não pode superar em $20 \%$ a espessura nominal do cobrimento:

$$
d_{\text {máx }} \leq 1,2 c_{\text {nom }}
$$

Ou seja, como o cobrimento empregado nos corpos-de-prova foi de $15 \mathrm{~mm}$, o diâmetro máximo do agregado deve ser $18 \mathrm{~mm}$.

\subsection{3. Água de Amassamento}

A água de amassamento utilizada foi a mesma fornecida pela companhia de distribuição de água da região de São Paulo, a SABESP.

\subsubsection{SAIS UtilizAdos COMO Eletrólito}

A concentração e as soluções alcalinas adotadas nesta pesquisa, tiveram como base estudos referentes à formação da película de passivação e da técnica de realcalinização abordados na revisão bibliográfica. Na Tabela 4.13 estão descritas as soluções, as suas concentrações, o pH e a fonte de pesquisa na qual a solução foi anteriormente empregada.

Tabela 4.13. Concentrações das soluções utilizadas na realcalinização dos corpos-deprova.

\begin{tabular}{cccc}
\hline Solução & Concentração & pH & Fonte \\
\hline $\mathrm{Na}_{2} \mathrm{CO}_{3}$ & $1 \mathrm{M}$ & 12 & Mietz (1998) \\
\hline $\mathrm{KOH}$ & $2,5 \mathrm{M}$ & 13 & Araujo (2004) \\
\hline $\mathrm{Ca}(\mathrm{OH})_{2}$ & saturada & 12,5 & Moreno et al. (2004) \\
\hline
\end{tabular}

\subsection{MÉTodos de EnSAIO}

\subsubsection{VERIFICAÇÃO dA FrEnTE DE CARbonataÇÃo E DE REALCALINIZAÇÃO}

A verificação das frentes de carbonatação e de realcalinização foi realizada através da aspersão do indicador químico de $\mathrm{pH}$, a fenolftaleína, o qual possibilitou a observação visual da área carbonatada na superfície recém-fraturada. Esta metodologia para verificação da profundidade de carbonatação foi realizada conforme a recomendação da RILEM CPC-18 (RILEM, 1988), sendo este o processo mais simples e de baixo custo para determinação da profundidade de carbonatação.

As características do indicador utilizado nesta pesquisa, tais como a mudança de cor e o intervalo de $\mathrm{pH}$ associado à mudança de cor, podem ser observadas na Tabela 4.14. 
Tabela 4.14. Características dos indicadores químicos utilizados nesta para a visualização da área carbonatada e realcalinizada.

\begin{tabular}{cccc}
\hline \multirow{2}{*}{ Indicador } & \multicolumn{3}{c}{ Intervalo de mudança de cor } \\
\cline { 2 - 4 } & Intervalo de pH & Mudança de cor & \multicolumn{1}{c}{ Solução } \\
\hline Fenolftaleína & $8,3-10,0$ & $\begin{array}{c}\text { incolor/ vermelho } \\
\text { carmim }\end{array}$ & $\begin{array}{l}\text { Dissolver 1g do reagente em } 50 \mathrm{~cm}^{3} \\
\text { de etanol e diluir com água até } \\
100 \mathrm{~cm}^{3 *}\end{array}$ \\
\hline $\left.\mathrm{C}_{6} \mathrm{H}_{4} \mathrm{COOC}\left(\mathrm{C}_{6} \mathrm{H}_{4} \mathrm{OH}\right)_{2}\right]$ & & & \\
\hline
\end{tabular}

\subsubsection{CARbonataÇÃo ACElerada}

Os corpos-de-prova não armados (utilizados nos ensaios físicos), tanto os de tempo de cura de 1 dia, quanto os de 28 dias, foram encaminhados para a câmara de carbonatação acelerada somente após 7 dias de finalização da cura. Este período de 7 dias para iniciar a carbonatação acelerada foi o tempo necessário para os corpos-deprova atingirem o equilíbrio de massa em uma sala fechada com umidade relativa de $75 \pm 5 \%$, mesma umidade interna da câmara de carbonatação acelerada.

Já os corpos-de-prova armados (utilizados nos ensaios de medidas eletroquímicas) demoraram mais tempo para entrar na câmara de carbonatação do que os não armados. Estes corpos-de-prova, após a finalização da cura, aguardaram o período necessário para a formação da película de passivação (aproximadamente 3 meses). Após a constatação da passivação das armaduras, então os corpos-de-prova foram encaminhados ao ensaio acelerado de carbonatação.

Antes de iniciar a carbonatação acelerada dos corpos-de-prova armados, foi reaplicada a graxa condutora de cobre (Figura 4.18) nas partes expostas das barras de todos os corpos-de-prova prismáticos. A graxa condutora, conforme mencionado anteriormente, teve a finalidade de evitar a corrosão nesta região da armadura e ao mesmo tempo garantir a sua condutividade, tanto para a realização das medidas eletroquímicas quanto para a realização da realcalinização eletroquímica.

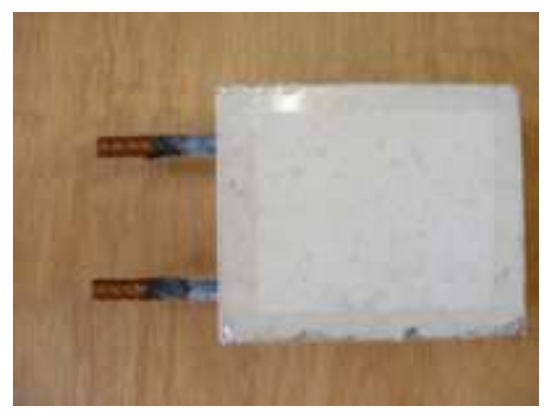

Figura 4.18. Detalhe da área exposta das barras dos corpos-de-prova prismáticos coberta com graxa condutora para evitar a corrosão das mesmas na câmara de carbonatação.

Os corpos-de-prova também tiveram cinco das suas seis faces seladas com fita adesiva antes de iniciada a carbonatação acelerada (Figura 4.19). Este cuidado foi 
tomado para garantir a ocorrência da carbonatação apenas na face não selada, pois somente esta face estará em contato com a malha da realcalinização eletroquímica, conforme será explanado no item 4.3.3.1.

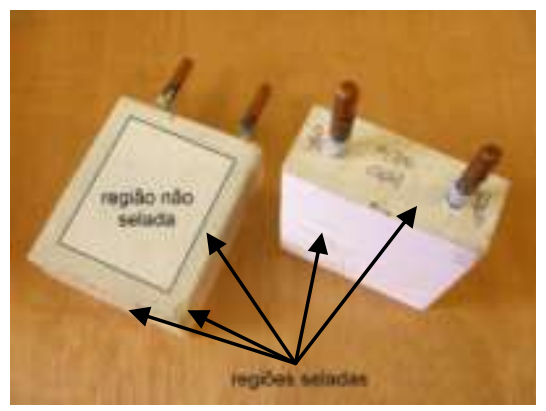

Figura 4.19. Detalhe dos corpos-de-prova selados com fita adesiva nas faces onde não era desejada a ocorrência da carbonatação acelerada.

O equipamento utilizado para realização do ensaio de carbonatação acelerada foi a câmara climatizada UUC 1000/2007 da BASS, com controle digital automático de $\mathrm{CO}_{2}$ (Figura 4.20).
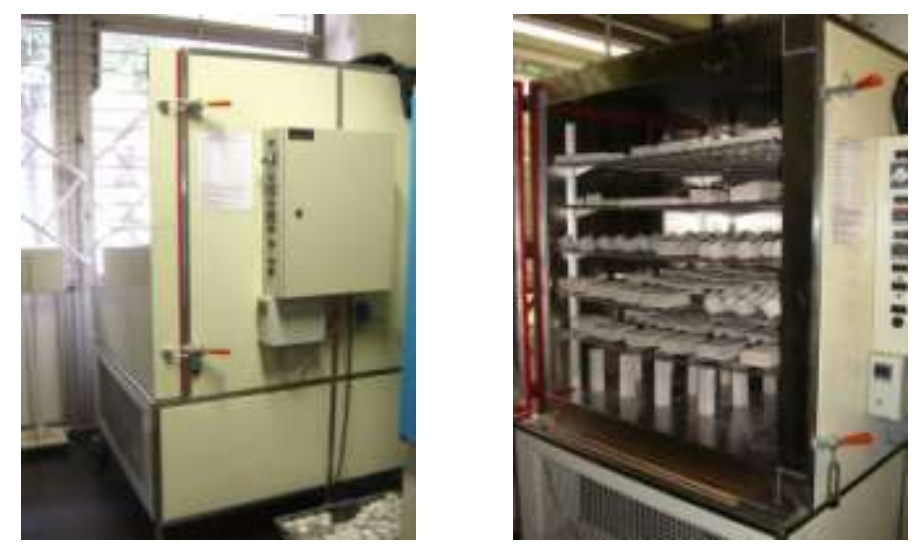

Figura 4.20. Câmara de carbonatação acelerada, com capacidade de 1000 litros, empregada para a realização dos ensaios acelerados de carbonatação.

Esta câmara de carbonatação acelerada é uma câmara climatizada com controles de temperatura (de 10 a $70^{\circ} \mathrm{C}$ ) e umidade (de 40 a 95-100\% ${ }^{5}$ ). A câmara também possui um controlador automático de concentração de gás carbônico (1 a 20\%) e um medidor digital do teor de $\mathrm{CO}_{2}$ no interior da mesma.

Tomando como base a Tabela 2.4 (do item 2.2.2.1) e a necessidade de carbonatar com rapidez os corpos-de-prova moldados, comprometendo o mínimo possível a matriz do concreto, o ensaio de carbonatação acelerada foi realizado com concentração de $\mathrm{CO}_{2}$ de $10 \%$, umidade relativa (UR) interna da câmara de $75 \pm 5 \%$ e temperatura controlada em $23 \pm 3^{\circ} \mathrm{C}$.

\footnotetext{
${ }^{5}$ Limitada por um "drewpoint" de $10^{\circ}$, na faixa de $20^{\circ} \mathrm{C}$ a $70{ }^{\circ} \mathrm{C}$.
} 


\subsubsection{EnSAios DE MEDidAs EletroquímicAs}

Nesta pesquisa, dois tipos de realcalinizações foram realizadas: a química por absorção e difusão de soluções alcalinas, e a eletroquímica. Em ambas realcalinizações, as soluções alcalinas empregadas foram as mesmas, e conforme o descrito anteriormente no item 4.1.1.3. A confirmação da realcalinização do concreto carbonatado foi verificada, conforme discutido no item 4.3.1, através da aspersão do indicador químico de $\mathrm{pH}$. A repassivação das armaduras foi determinada através das técnicas de medidas eletroquímicas de potencial de corrosão - Ecorr e espectroscopia de impedância eletroquímica - EIE (item 4.3.3.3). Durante as realcalinizações, os corposde-prova permaneceram em uma sala com temperatura e umidade relativa controladas de $23 \pm 3^{\circ} \mathrm{C}$ e $75 \pm 5 \%$, respectivamente.

Nos corpos-de-prova sem armadura, utilizados nos ensaios físicos, foi realizada somente a técnica de realcalinização química por absorção e difusão das soluções alcalinas.

Já nos corpos-de-prova armados, a realcalinização realizada foi tanto através da técnica química por absorção e difusão das soluções alcalinas na superfície dos corpos-de-prova carbonatados, como também através da técnica de realcalinização eletroquímica.

Como esta pesquisa visa a verificação da repassivação da armadura através da técnica de realcalinização química por absorção e difusão das soluções alcalinas, optou-se por também verificar a repassivação das armaduras através da técnica eletroquímica. Pois, caso a técnica química por absorção e difusão não propiciasse a repassivação da armadura, seria possível verificar se a não ocorrência deste fato é devido à técnica química por absorção e difusão ou era um problema das técnicas de realcalinização como um todo.

\subsubsection{REALCALINIZAÇÃO ELETROQUímiCA (RAE)}

O sistema de realcalinização eletroquímica empregado nesta pesquisa foi baseado no sistema elaborado por Monteiro (2002), e o proposto pela norma européia EN 14038-1 (CEN, 2005). A norma européia EN 14038-1 (CEN, 2005) determina que a densidade de corrente não deve exceder de $4 \mathrm{~A} / \mathrm{m}^{2}$ de superfície tratada e a duração da carga empregada não deve ser inferior a 100 horas. Outro parâmetro estabelecido foi de que a densidade de corrente total aplicada durante o tratamento não ultrapassasse 200 A.h/m². 
Os corpos-de-prova realcalinizados eletroquimicamente demoraram 15 dias para completar a carga de corrente aplicada recomendada pela norma EN 14038-1 (CEN, 2005), sem ultrapassa a densidade decorrente de $4 \mathrm{~A} / \mathrm{m}^{2}$.

O sistema eletroquímico consistiu de uma fonte para aplicação da corrente e de uma malha utilizada como ânodo.

\section{a) $\underline{\text { FONTE }}$}

Para a realização da realcalinização eletroquímica, foi utilizado o mesmo sistema elétrico elaborado por Monteiro (2002) durante o seu doutorado (Figura 4.21 (a) e (b)), no qual foi alterada apenas a quantidade de corrente aplicada. A Figura 4.21 (a) ilustra um esquema de como o corpo-de-prova ficará conectado ao sistema eletroquímico, e a Figura 4.21 (b) ilustra o sistema desenvolvido para ser aplicado neste trabalho. No qual a fonte (A) com um circuito de corrente em paralelo com resistor (B) terá o pólo positivo conectado à malha de aço inox $(\mathrm{C})$ e o pólo negativo conectado à armadura do corpo-de-prova (D). Para o eletrólito ficar em contato de forma adequada à malha, no fundo do recipiente foram colocados anéis de PVC (E) que permitiram o contato do eletrólito à malha e ao corpo-de-prova de forma adequada.

(a)

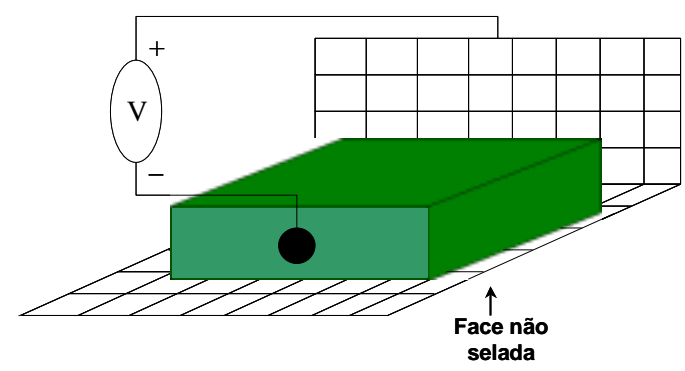

(b)

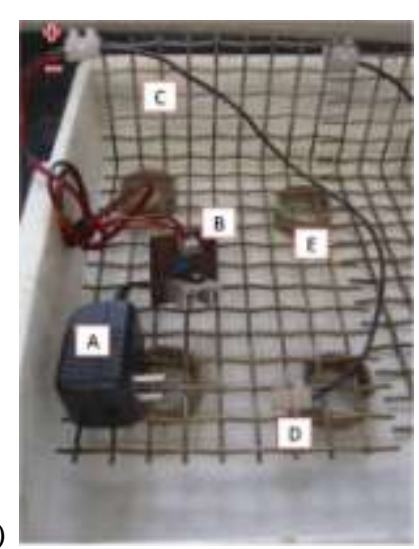

Figura 4.21. (a) Esquema do sistema eletroquímico a ser aplicado na realcalinização. (b) sistema de realcalinização eletroquímica.

A fonte de corrente utilizada para manter a corrente constante e igual ao longo do ensaio, sem a necessidade de aumentar a tensão à medida que a realcalinização fosse atingindo todo o cobrimento, possui tensão de entrada bivolt (110 ou $220 \mathrm{~V}) \mathrm{e}$ saída de $18 \mathrm{~V}$, além de um circuito de corrente em paralelo com resistor. Este circuito está esquematizado conforme a Figura 4.22. 


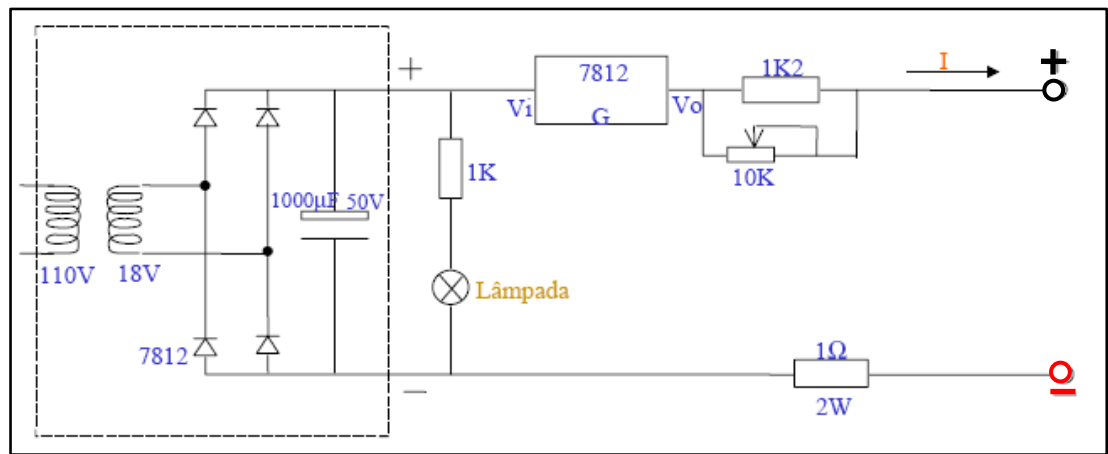

Figura 4.22. Esquema do circuito utilizado como fonte de corrente (Monteiro, 2002).

O circuito de corrente em paralelo com resistor incorporado à fonte teve a função de liberar $12 \mathrm{~V}$ da tensão de saída da fonte para o circuito, dissipando o restante em forma de calor. Quando colocado em paralelo com um resistor R, a corrente que circula pelo circuito é dada pela Equação 4.1 (Monteiro, 2002).

$\mathrm{I}=\frac{12}{\mathrm{R}}$

Equação 4.1

Onde,

I é a corrente desejada;

$\mathrm{R}$ é o resistor em paralelo com regulador.

Esta corrente foi mantida constante desde que a voltagem necessária para que ela circule sobre o circuito seja menor que $12 \mathrm{~V}$. Como um corpo-de-prova exige aproximadamente $8 \mathrm{~V}$ para esta corrente circular, foi feita uma fonte de corrente para cada cuba eletrolítica.

\section{b) $\underline{\hat{A N O D O}}$}

Inicialmente, o ânodo de aço inoxidável a ser utilizado seria o mesmo dos experimentos de extração eletroquímica de cloretos realizados por Monteiro em 2002. No entanto, durante os teste preliminares foi observado que algumas partes da malha não estavam mais devidamente conectadas, ou seja, soldadas.

Assim, foram confeccionadas chapas de aço inoxidável perfuradas, com aberturas de $20 \mathrm{~mm}$, garantindo a conectividade elétrica em toda a extensão da mesma (Figura 4.23). 


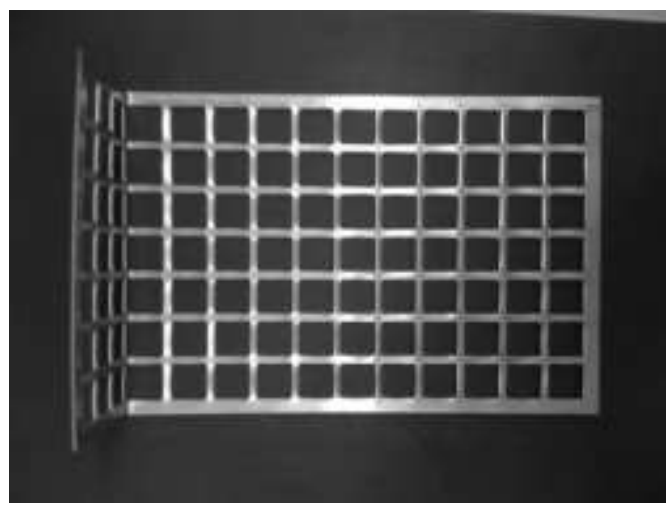

Figura 4.23. Chapa de aço inoxidável utilizada como ânodo no tratamento de RAE.

O aço inoxidável foi escolhido como ânodo por ser um material de alta resistência à corrosão e de custo bem inferior ao titânio, garantindo um bom resultado.

\subsubsection{REALCALINIZAÇÃO QUÍMICA POR ABSORÇÃO E DIFUSÃO (RAQ)}

O sistema utilizado na realcalinização química consistiu na realização de ciclos de imersão e secagem durante o tratamento. Cada ciclo durava 5 dias, onde nos 2 primeiros dias os corpos-de-prova ficavam imersos na solução alcalina, e nos três seguintes eram colocados em uma estufa ventilada a $40^{\circ} \mathrm{C}$ para secar. Esses ciclos foram realizados para adiantar a penetração da solução alcalina no interior dos corpos-deprova.

A cada 30 dias, o corpo-de-prova destinado ao controle da profundidade de realcalinização (chamados de corpos-de-prova irmãos) teve a sua superfície fraturada conforme a recomendação da RILEM CPC-18 (RILEM, 1988), para verificar o avanço da realcalinização no concreto carbonatado. A depender da profundidade de realcalinização alcançada no intervalo de tempo instituído, o intervalo de fratura foi diminuído para uma semana.

Durante a imersão dos corpos-de-prova em caixas com solução alcalina, a solução alcalina teve o seu valor de $\mathrm{pH}$ monitorados a cada 3 dias. Ao verificar a queda do valor de $\mathrm{pH}$ em um ponto, a solução era imediatamente troca.

\subsubsection{TÉCNICAS DE MEDIDAS ELETROQUÍMICAS}

A finalidade deste ensaio foi verificar a condição eletroquímica da armadura no interior do concreto (passivada ou despassivada). A constatação do estado da armadura no interior do concreto foi realizada através das técnicas eletroquímicas de medida do potencial de corrosão (Ecorr), através de um eletrodo de referência conectado à um multímetro, e da espectroscopia de impedância eletroquímica (EIE), 
através de um potenciostato e um detector de resposta em frequiência (ou frequencímetro).

Como no ensaio de realcalinização eletroquímica apenas uma das faces do corpo-de-prova teve contato com a malha de aço inoxidável, optou-se por selar (faixa verde ao redor do corpo-de-prova da Figura 4.24) as faces que não entrariam em contato com a malha. Com esta medida apenas a face que seria realcalinizada (ou seja, não selada) foi carbonatada (Figura 4.24).

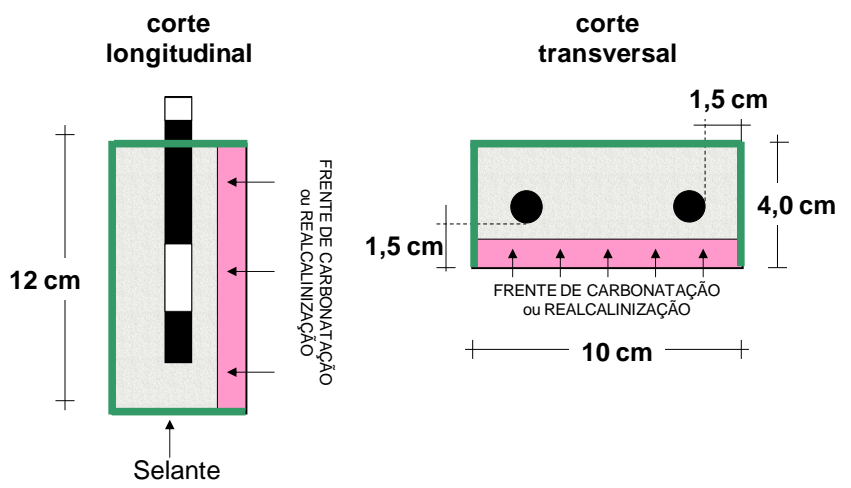

Figura 4.24. Detalhe da colocação do selante e da atuação da frente de carbonatação ou realcalinização no corpo-de-prova.

Durante as realcalinizações a umidade relativa dos corpos-de-prova passa de $75 \%$ (umidade interna durante o período de passivação das armaduras e da câmara de carbonatação acelerada) para $100 \%$ de UR. Esta mudança de umidade provoca uma diferença considerável nos potenciais de corrosão e nas leituras de EIE devido à queda da resistividade elétrica do concreto, comprometendo a análise comparativa entre os resultados nas diferentes fases dos ensaios. Como solução para esta situação, foi realizada a secagem dos corpos-de-prova após a finalização dos tratamentos de realcalinização em estufa ventilada à $40^{\circ} \mathrm{C}$ até atingir constância de massa. Ao finalizar a secagem dos corpos-de-prova, os mesmos eram acondicionados nas caixas com umidade relativa constante de $75 \%$ UR, assim foi possível correlacionar os dados eletroquímicos obtidos após a finalização do tratamento com os das fases anteriores.

\section{a) MEDIDA DE POTENCIAL DE CORROSÃO}

A utilização da medida do potencial de corrosão tem a vantagem de ser uma técnica não-destrutiva e de fácil e rápida aplicação, não sendo necessário o emprego de aparelhos caros e sofisticados. Porém, apresenta a desvantagem de apenas fornecer uma medida qualitativa, relativa e aproximada, do processo de corrosão instalado sobre a 
armadura. Ou seja, do seu registro não se obtém nenhum dado quantitativo da cinética da corrosão (Figueiredo, 1999).

A medida do potencial de corrosão da armadura, normalizada pela ASTM C876 (1991), consiste no registro da diferença de potencial (voltagem) entre a armadura e um eletrodo de referência, que é colocado em contato com a superfície do concreto. Os eletrodos de referência mais utilizados na investigação do estado das armaduras imersas em concreto são os de calomelano saturado (ECS) e os de cobre/sulfato de cobre (ESC).

Para realizar a leitura da diferença de potencial é necessário conectar um voltímetro, com resolução em milivolts, à armadura e a um eletrodo de referência. O eletrodo de referência deve ficar em contato com a superfície de concreto através de uma esponja de alta condutividade úmida, destinada a melhorar a condutividade elétrica entre o eletrodo de referência e a superfície do concreto (Figura 4.25).

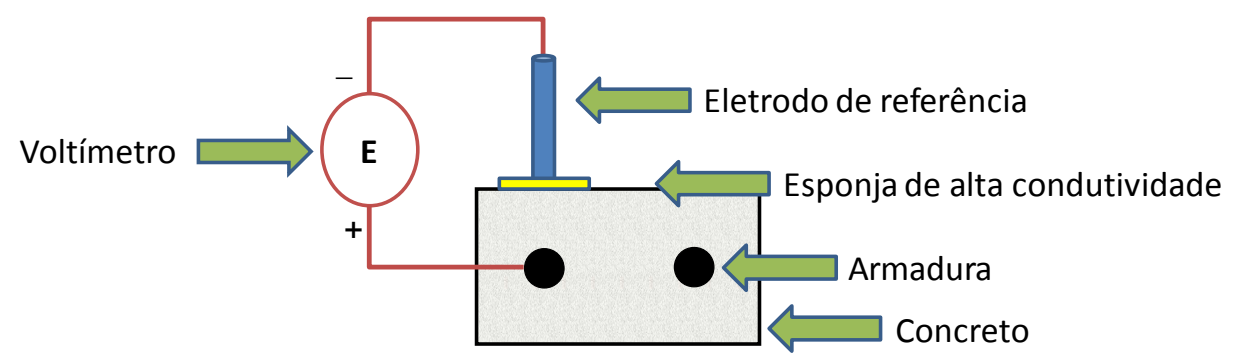

Figura 4.25. Esquema básico do método de determinação do potencial de corrosão da armadura.

Com os valores obtidos de potencial de corrosão têm-se informações qualitativas sobre o estado superficial da armadura, indicando se a mesma apresenta-se em estado passivo ou ativo de corrosão. Com isto consegue-se realizar um mapeamento dos potenciais eletroquímicos da estrutura e, desta forma, descobrir as regiões com tendência ou não de sofrer corrosão. A partir desses resultados, é possível o monitoramento desses potenciais com o tempo, permitindo saber o momento no qual o aço perde a sua camada de passivação.

ASTM C876 (1991) apresenta uma correlação entre intervalos de diferença de potencial, em relação a um eletrodo de referência de cobre/sulfato de cobre $\left(\mathrm{Cu} / \mathrm{CuSO}_{4}\right)$, e a probabilidade de ocorrência de corrosão (Tabela 4.15). 
Tabela 4.15. Critérios de avaliação da corrosão através de medidas de potencial de corrosão (ASTM C876, 1991).

\begin{tabular}{cc}
\hline Ecorr $\left(\mathbf{m V}, \mathbf{C u} / \mathbf{S O}_{\mathbf{4}} \mathbf{C u}\right)$ & Probabilidade de corrosão \\
\hline$>-200$ & $<5 \%$ \\
\hline Entre $-200 \mathrm{e}--350$ & $50 \%$ \\
$<-350$ & $>95 \%$ \\
\hline
\end{tabular}

Vale ressaltar que tais valores não devem ser tomados como absolutos, sendo apenas aceitáveis como referência. Na realidade, essas faixas de potenciais foram determinadas empiricamente após estudos de corrosão em tabuleiros de pontes sujeitas à ação de cloretos, oriundas de casos norte-americanos, no início da década de setenta (Helene, 1993).

Os potenciais eletroquímicos são parâmetros termodinâmicos que dependem de inúmeras variáveis como umidade, tipo de cimento, resistividade, qualidade do concreto, espessura do cobrimento, temperatura, frente de carbonatação, presença de cloretos, entre outras. Seus valores numéricos indicam o balanço entre as reações anódicas e catódicas, não fornecendo, entretanto, informações quantitativas sobre a velocidade ou intensidade de corrosão da armadura (Sá, 2006). Os valores de potencial, conforme já explicado anteriormente, só podem ser associados à probabilidade de corrosão.

As medidas de potencial de corrosão desta pesquisa foram realizadas utilizando um eletrodo de referência de calomelano saturado ( $\left.\mathrm{Hg} / \mathrm{HgCl}, \mathrm{KCl}_{\mathrm{sat}}\right)$, conectado a um multímetro digital. Estes eletrodos são constituídos, externamente, por uma solução ácida diluída de $\mathrm{HCl}$, e internamente possui um eletrodo de referência de calomelano saturado $(\mathrm{Hg} / \mathrm{HgCl})$. A ligação entre ambos é feita através da ponte salina $\mathrm{KCl}_{\text {sat }}$, esta ponte salina permite que ao colocar o eletrodo em contato com a superfície do concreto, ocorra a formação de um potencial de $\mathrm{H}^{+}$da suspensão com o $\mathrm{H}^{+}$do eletrodo, possibilitando a medição deste através do multímetro.

Uma vez que a maioria dos dados publicados em artigos, e na própria ASTM C876 (1991), estabelece as faixas de probabilidade de corrosão no potencial obtido com o eletrodo de cobre/sulfato de cobre (ESC), torna-se interessante, a fim de facilitar as comparações entre artigos e trabalhos, a conversão do potencial obtido com o eletrodo de calomelano saturado (ECS) para o ESC. Assim, para a conversão prevista em Wolynec (2003), é necessário somar aos valores de potencial encontrado com o ECS a constante de $-0,074 \mathrm{~V}$ (ou $-74 \mathrm{mV}$ ). 


\section{b) ESPECTROSCOPIA DE IMPEDÂNCIA ELETROQUÍMICA (EIE)}

A técnica de espectroscopia de impedância eletroquímica (EIE), ou método de impedância alternada (impedância $\mathrm{AC}$ ou $\mathrm{CA}$ ), é uma técnica que vem sendo empregada cada vez mais nos estudos de materiais. No entanto, a sua utilização é restrita aos estudos desenvolvidos em laboratório (Cascudo, 1991, Song, 2000, e Rha et al, 2001), devido às dificuldades relativas à distribuição não uniforme da corrente ao longo das barras das estruturas "in situ", principalmente para altas freqüências aplicadas à armadura. Desta maneira, se torna praticamente impossível restringir o sinal elétrico em uma região de análise, agravando o conhecimento da área que está sendo efetivamente polarizada.

A corrente alternada, com uma determinada freqüência, é programada pelo computador e aplicada no eletrodo de trabalho (armadura) através do potenciostato. A resposta do eletrodo é recebida pelo detector de resposta em freqüência (analisador de espectro de freqüência), que encaminha os dados para o computador para processamento (Figura 4.26).

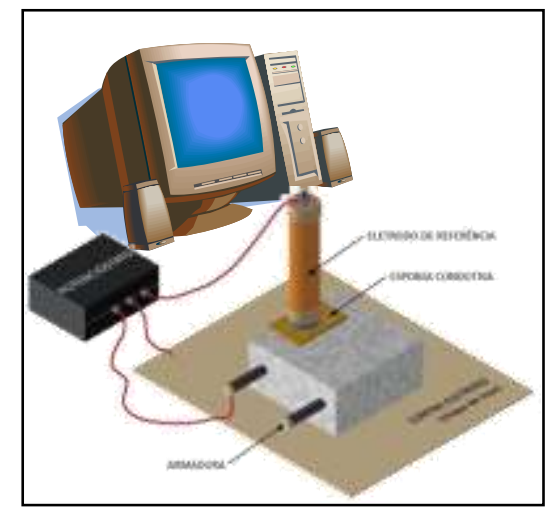

Figura 4.26. Esquema da obtenção da impedância eletroquímica em um sistema de três eletrodos (Medeiros, 2008).

A técnica permite identificar diferentes fenômenos que ocorrem em um sistema aço/concreto. Dentre eles estão: informações sobre a cinética do processo através da taxa de corrosão; detecção e caracterização do estado da armadura quanto ao seu estado passivo ou ativo; determinação da resistência do eletrólito ou do concreto (permitindo a determinação da resistência ôhmica do mesmo); resistência e capacitância de filmes interfaciais sobre o aço; capacitância da dupla camada e resistência de polarização.

A EIE consiste na aplicação de uma corrente elétrica alternada de pequena amplitude (de \pm 10 a $30 \mathrm{mV}$ ) a um eletrodo imerso no concreto, de forma a não 
perturbar as propriedades do eletrodo. Após a aplicação desta corrente, é realizada a medida da perturbação inicial aplicada com a resposta obtida pelo eletrodo, através da medida da mudança de fase $(\theta)$ dos componentes de corrente e voltagem, e pela medida de suas amplitudes. A perturbação inicial é uma perturbação de potencial $(\Delta \mathrm{E})$, do tipo senoidal, e a resposta do eletrodo é uma corrente $(\Delta \mathrm{I})$, também senoidal, porém com diferença de fase $(\theta)$ em relação ao sinal aplicado, em um amplo intervalo de freqüência $(f)$. Portanto a impedância do sistema $(Z)$ mede a relação entre o potencial alternado mandado para célula $(\Delta \mathrm{E})$ e a $\Delta \mathrm{I}$ recebida como resposta pelo analisador de espectro de freqüência.

Assim, quanto maior for a impedância do sistema $(Z)$, mais passivo será o sistema, ou seja, maior será a restrição do sistema (eletrodo) à condução de corrente, significando que a taxa de corrosão ao longo do eletrodo em análise será a mais baixa possível.

De acordo com Cascudo (1991), a amplitude e a mudança de fase dos diagramas de Nyquist e de Bode dependem da variação de freqüência determinada para o ensaio, podendo variar de $100 \mathrm{kHz}$ a $10 \mathrm{mHz}$. No entanto, este intervalo de variação de freqüência pode sofrer alteração de pesquisa para pesquisa, pois quanto mais baixa a frequiência utilizada, maior será o tempo necessário para a realização destas medidas.

O potenciostato proporciona a obtenção de valores de taxa de corrosão até nos meios mais resistivos, sem a necessidade de se realizar a compensação de queda ôhmica, e ainda possibilita a determinação da resistividade elétrica do material, da resistência de polarização e da capacitância da dupla camada elétrica em uma mesma medida (Silva, 2006).

\section{b.1) DIAGRAMA DE NYQUIST}

Silva (2006) explica que sempre um circuito equivalente estará associado ao diagrama de Nyquist (Figura 4.27), onde os elementos deste circuito correspondem às partes do concreto armado. Circuito este representado por resistores e capacitores, onde o resistor é o elemento utilizado para modelar a resistência do eletrólito, e o capacitor simula os efeitos da dupla camada elétrica e alguma eventual deposição na armadura.

Eventualmente, quando o processo corrosivo é controlado pelo transporte de massa por difusão, de alguma substância envolvida na reação, acaba por aparecer o elemento Walburg $\left(\mathrm{Z}_{\mathrm{D}}\right)$, também conhecido como impedância difusional. 
Onde $R c$ corresponderia à resistência da solução contida nos poros do concreto (resistência entre o eletrodo de trabalho e o eletrodo de referencia), $R f$ e $C f$ corresponderiam ao filme interfacial, $C d c, R p$ e $Z_{D}$ ou $W$ (impedância difusional de Walburg) à dupla camada elétrica.
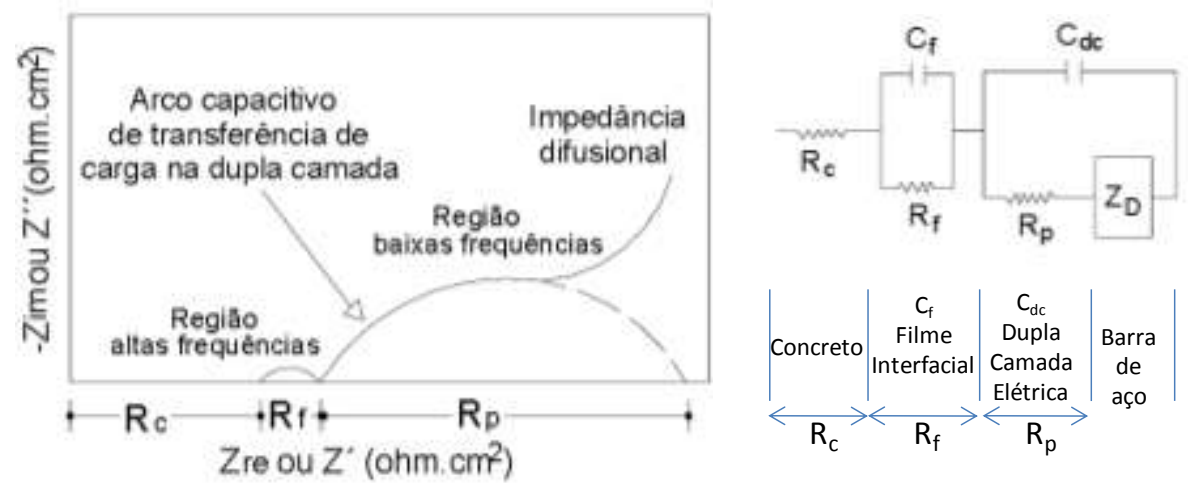

Figura 4.27. Diagrama de Nyquist, com o seu circuito equivalente, para o caso do concreto armado, mostrando o efeito do elemento de Walburg (adaptada de Silva, 2006, e Cascudo, 1991).

O eixo horizontal representa a parte real da impedância (Zre ou Z'), o componente de resistência, e o eixo vertical representa o componente imaginário (-Zim ou Z"), a reatância capacitiva ou indutiva (Cascudo, 1991). Uma vez construído o diagrama de Nyquist, faz-se a extrapolação da parte direita do último semicírculo até encontrar o eixo horizontal (linha tracejada da Figura 4.27). A impedância é então representada pela equação:

$$
Z=\sqrt{\left(Z^{\prime}\right)^{2}+\left(Z^{\prime \prime}\right)^{2}}
$$

A região de baixa freqüência $(<1 \mathrm{~Hz})$ é utilizada para caracterizar a extensão da corrosão na superfície da barra, já a região de média frequiência (entre $10.000 \mathrm{~Hz}$ e $1 \mathrm{~Hz}$ ) é normalmente atribuída ao processo corrosivo. A região de alta freqüência (> $10.000 \mathrm{~Hz}$ ) deve-se às propriedades interfaciais do cobrimento, ou seja, do concreto.

Assim, o diâmetro do último semicírculo é a resistência à transferência de carga $(\mathrm{Rt})$, equivalente à amplitude da resistência de polarização $(\mathrm{Rp})$, resistência esta pela qual é possível estimar a velocidade de corrosão instantânea (icorr) pela Equação 4.3 de Stern-Geary (Wolynec, 2003).

$$
i_{\text {corr }}=\frac{B}{R_{p} \times S}
$$

Onde,

Icorr é a taxa, densidade ou intensidade de corrente de corrosão $\left(\mu \mathrm{A} / \mathrm{cm}^{2}\right)$; 
B é a constante de Stern-Geary, uma constante em função das características do sistema metal/meio;

Rp é a resistência de polarização $(\mathrm{K} \Omega)$;

$\mathrm{S}$ é a área efetiva do estudo $\left(\mathrm{cm}^{2}\right)$.

$\mathrm{O}$ valor de B pode ser obtido a partir das constantes de Tafel, que variam em função do estado da armadura no interior do concreto, do mecanismo de corrosão e das características do eletrólito. Como não é possível determinar as constantes de Tafel através do potenciostato, o valor de $\mathrm{B}$ foi adotado de acordo com o sugerido por Andrade e Gonzalez (1978), citados por Gu et al. (1999). Os autores sugerem os valores de $26 \mathrm{mV}$ para armaduras em estado passivo e de $52 \mathrm{mV}$ para as no estado ativo de corrosão.

Uma vez obtido o valor de icorr é possível classificar a corrosão em função da velocidade do processo, conforme a recomendação da RILEM TC 154-EMC (RILEM, 2004), ilustrada na Tabela 4.16.

Tabela 4.16. Critérios para avaliar os resultados de velocidade de corrosão (RILEM TC 154-EMC, 2004).

\begin{tabular}{cc}
\hline icorr $\left(\boldsymbol{\mu A} / \mathbf{c m}^{2}\right)$ & Velocidade do processo \\
\hline$<0,1$ & Desprezível \\
0,1 a 0,5 & Moderada \\
0,5 a 1 & Elevada \\
\hline$>1$ & Muito elevada \\
\hline
\end{tabular}

É importante ressaltar que o diagrama de Nyquist possui algumas desvantagens, como o fato da freqüência não aparecer de forma explícita, embora a resistência ôhmica e de polarização possam ser facilmente lidas (conforme já explanado), e da capacitância do eletrodo só poder ser calculada após conhecer a freqüência no máximo da componente imaginária.

\section{b.2) DIAGRAMA DE BODE}

As representações dos dados de impedância através dos diagramas de Bode não são muito freqüentes nos trabalhos científicos, principalmente os que envolvem concreto. O qual geralmente só é representado pelo diagrama de Nyquist. No entanto, a análise dos diagramas de Bode é tão importante quanto a do diagrama de Nyquist.

Os diagramas de Bode organizam os dados como o logaritmo do módulo da impedância $(\log |z|)$ em ohms $(\Omega)$, e a mudança de fase $(\theta)$, ou ângulo de fase obtidos em grau, ambos como ordenadas em função do logaritmo da freqüência $(\log (f))$ obtida em Hertz $(\mathrm{Hz})$. 
A vantagem de Bode em relação ao Nyquist é o uso da freqüência, o que permite uma ampla visualização dos efeitos resistivos e capacitivos.

De acordo com Cascudo (1991), é possível determinar a capacitância da dupla camada elétrica $(\mathrm{Cdc})$ a partir do gráfico do logaritmo da frequiência angular $(\log (\omega))$ versus o ângulo de fase $(\theta)$, e determinar a resistência ôhmica $(R \Omega)$ e resistência à transferência de carga $(\mathrm{Rt})$ através do gráfico $\log (\omega)$ versus $\log |\mathrm{Z}|$ (Figura 4.28).

(a)

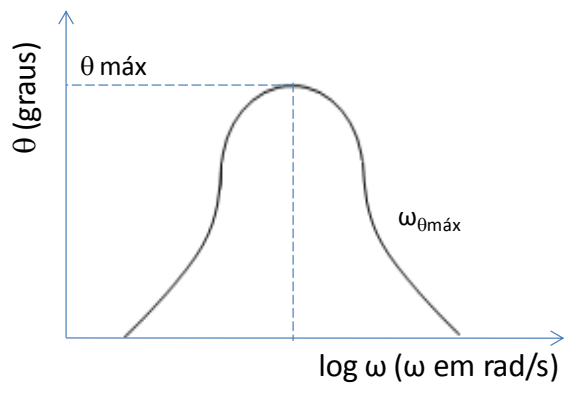

(b)

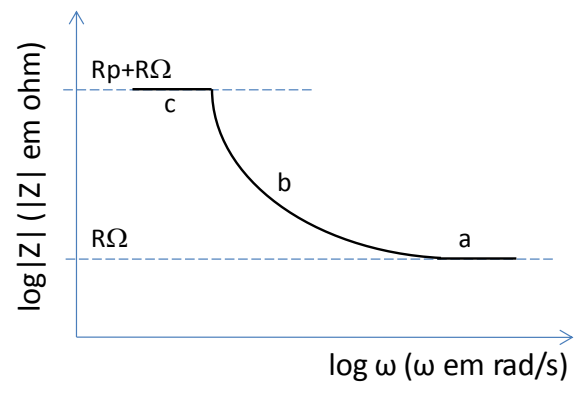

Figura 4.28. Diagrama de Bode representando a impedância (módulo e ângulo de fase) de um sistema eletroquímico de corrosão em função da freqüência angular (adaptada de Cascudo, 1991).

No entanto, Cascudo (1991) ressalta que estas determinações, a partir dos gráficos da Figura 4.28, são possíveis apenas para um circuito equivalente simples do tipo Randles (Figura 4.29). Neste tipo de circuito equivalente, a taxa de corrosão é unicamente controlada por ativação, e não há a inclusão dos efeitos de concentração (difusão) devido à impedância difusional de Walburg, que sempre ocorre em se tratando de concreto armado (anteriormente na Figura 4.27).

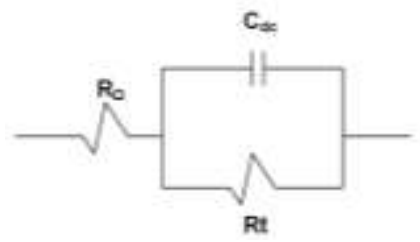

Figura 4.29. Circuito equivalente simples do tipo Randles (Machado, 2004).

Mesmo a técnica de EIE sendo bastante completa, e de muitas possibilidades, a interpretação dos seus resultados em se tratando de concreto armado, é muito mais complexa. Alguns potenciostatos e softwares facilitam esta interpretação já fornecendo, de imediato, alguns parâmetros como a capacitância de dupla camada elétrica $(\mathrm{Cdc})$, a resistência de polarização $(\mathrm{Rp})$, entre outros. Entretanto, isto só é possível pelo fato do programa possibilitar a escolha da variável referente ao circuito 
equivalente no qual o sistema deverá se basear, dando ainda a possibilidade de criar novos circuitos equivalentes.

Como o equipamento e o software disponíveis no laboratório não ofereciam essas possibilidades, a análise dos resultados será muito mais qualitativa do que quantitativa.

A impedância $(Z)$ da armadura imersa no concreto, desta pesquisa, foi obtida através do potenciostato da marca EG\&G Instruments/Modelo 273A (Figura 4.30), do Laboratório de Corrosão da Engenharia Civil da USP (Labcorr), e do software "Electrochemistry PowerSuite".

(a)
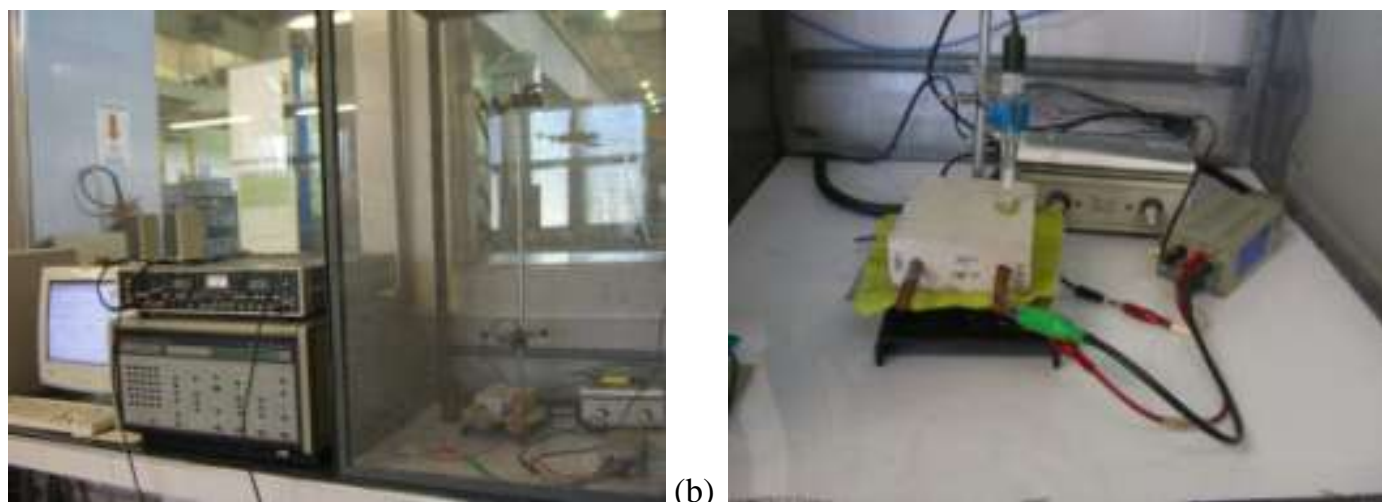

Figura 4.30. (a) Potenciostato da marca EG\&G Instruments/Modelo 273A. (b) Detalhe da leitura da EIE nos corpos-de-prova de ensaio.

A fim de possibilitar a aplicação da diferença de potencial na armadura, foi colocada uma chapa de aço inoxidável como contra-eletrodo na superfície do corpo-deprova, tomando o cuidado de colocar uma esponja super absorvente entre a superfície do corpo-de-prova e a chapa para garantir o contato elétrico.

\subsubsection{ENSAIOS FÍsICOS}

Os ensaios físicos realizados nesta pesquisa foram:

- Absorção de água por capilaridade;

- $\quad$ Absorção de água por imersão e fervura;

- Durabilidade da realcalinização química à recarbonatação.

Os corpos-de-prova utilizados nos ensaios físicos tiveram as suas dimensões alteradas, para possibilitar a realização dos mesmos. Embora a câmara de carbonatação acelerada fosse grande, com capacidade de 1000 litros, o volume total de corpos-deprova (tantos dos ensaios físicos, quanto dos eletroquímicos) superou em muito o volume disponível da câmara. 
Como a dimensão dos corpos-de-prova eletroquímicos não poderia ser alterada, ficou decidido que os corpos-de-prova dos ensaios físicos, cilíndricos de $5 \times 10 \mathrm{~cm}$, seriam serrados ao meio.

Com este arranjo foi possível reduzir o universo de 176 corpos-de-prova de dimensão 5x10 cm (Tabela 4.6 e Tabela 4.7), para 88 corpos-de-prova $5 \times 10 \mathrm{~cm}$. A qual possibilitou o uso da câmara de carbonatação acelerada sem maiores problemas.

No entanto, antes desta decisão ser colocada em prática, foi realizado o ensaio piloto de ascensão de água por capilaridade (item 4.3.4.1). O objetivo deste ensaio piloto foi verificar se a altura da ascensão capilar superaria a altura do corpo-deprova.

\subsubsection{ENSAIO PILOTO DE ASCENSÃO DE ÁGUA POR CAPILARIDADE}

Como foi descrito anteriormente, o objetivo deste ensaio piloto foi verificar a possibilidade de realizar o ensaio com corpos-de-prova cilíndrico de dimensões diferentes ao prescrito pela RILEM TC 116-PCD (RILEM, 1999). Como as dimensões nos corpos-de-prova a serem utilizados nesta pesquisa eram de $5 \times 5 \mathrm{~cm}$, foi verificado através do ensaio piloto se a altura da ascensão capilar superaria a altura do corpo-deprova.

Os corpos-de-prova cilíndricos moldados foram os de dimensão cilíndrica de $5 \times 10 \mathrm{~cm}$, e serrados ao meio, para então serem iniciados os preparativos para o ensaio piloto.

Os corpos-de-prova tiveram todas as fases de pré-condicionamento e selagem das fases prescritas pela norma adotada.

Durante o ensaio, os corpos-de-prova cilíndricos tiveram a face serrada (por estar livre de desmoldante) imersa em um recipiente (Figura 4.31) com uma película de água de $3 \mathrm{~mm}$ durante 24 horas.
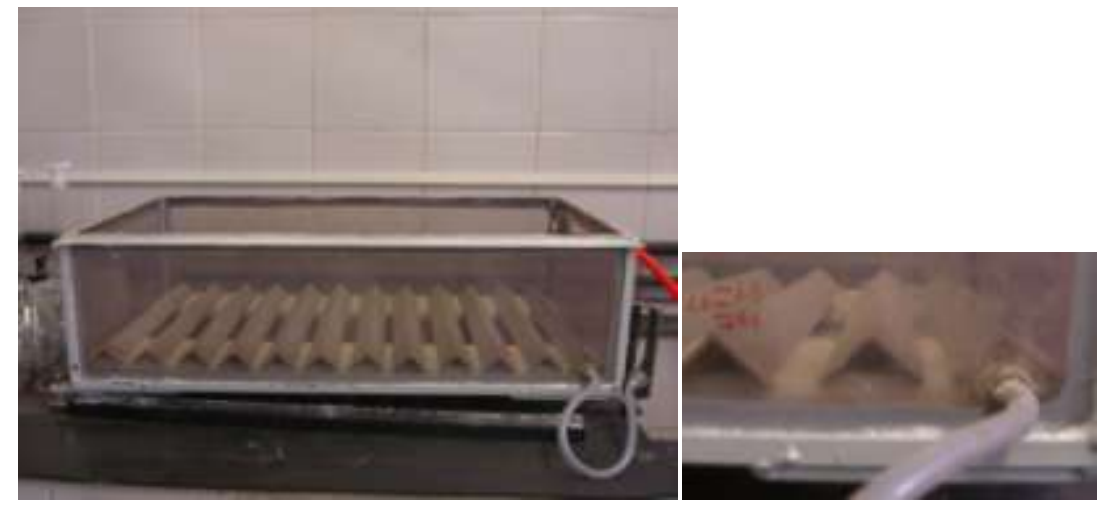

Figura 4.31. Recipiente nos qual os corpos-de-prova ficaram imersos para o ensaio, detalhe à direita das escalas para conferência da altura da película de água. 
Como o intuito deste piloto não era verificar a quantidade de água absorvida, as medições de aumento de massa nos intervalos de 10 minutos, 1,4 e 24 horas foram descartadas. Ao final das 24 horas os corpos-de-prova foram rompidos transversalmente e verificada a altura da ascensão capilar (Figura 4.32). Na Figura 4.32 é possível observar que a altura capilar em nenhuma das situações testadas (corpo-deprova de a/c 0,65 e 0,80) chegou a altura máxima do corpo-de-prova, o máximo observado foi até a metade da altura do corpo-de-prova $(2,5 \mathrm{~cm})$. Os resultados obtidos possibilitam a realização do ensaio de absorção capilar de acordo com o prescrito pela RILEM TC 116-PCD (RILEM, 1999) com corpos-de-prova com diâmetro diferente do prescrito pela citada norma.

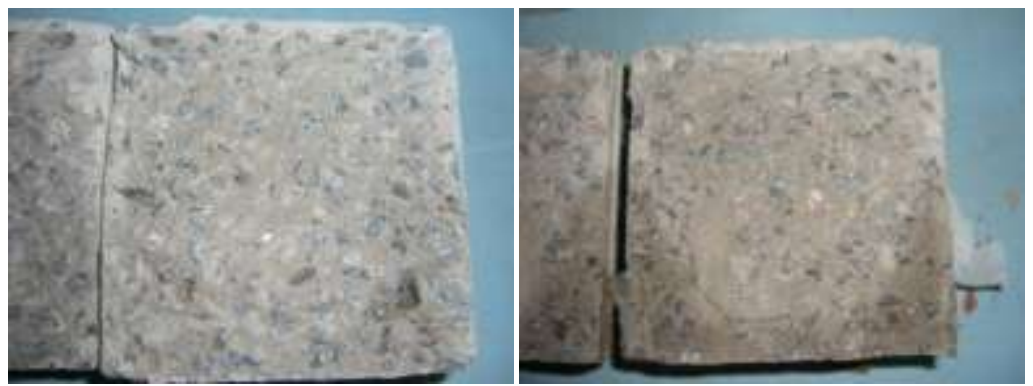

Figura 4.32. Corpos-de-prova rompidos transversalmente após a finalização do ensaio de absorção capilar.

4.3.4.2. ENSAio de ABSORÇÃo E ASCENSÃo CAPILAR DA ÁGUA POR CAPILARIDADE

O ensaio de absorção de água por capilaridade nos corpos-de-prova de referência, carbonatados e realcalinizados seria realizado de acordo com a norma brasileira NBR 9779 de "Determinação da absorção de água por capilaridade" (ABNT, 1995). Porém, em razão da grande quantidade de corpos-de-prova a serem colocados na câmara de carbonatação acelerada foi decidido não mais utilizar a norma brasileira NBR 9779 (ABNT, 1995). Assim, o ensaio foi realizado conforme prescrito da norma da RILEM TC 116-PCD (RILEM, 1999) "Permeability of concrete as a criterion of its durability". Esta norma prescreve que os corpos-de-prova sejam cilíndricos, de diâmetro de $15 \mathrm{~cm}$ e altura de $5 \mathrm{~cm}$, e com no mínimo três repetições.

A norma prescreve ainda um pré-condicionamento para que ocorra uma redistribuição das fases da mistura. Esta redistribuição consiste em selar os corpos-deprova em sacos plásticos, e deixá-los em uma estuda ventilada de $50^{\circ} \mathrm{C}$ por um período de 14 a 27 dias. Ao finalizar este período de redistribuição, os corpos-de-prova foram retirados da estufa e colocados ainda selados em uma sala com temperatura controlada de $20^{\circ} \mathrm{C}$, por no mínimo 24 horas antes de ser realizado o ensaio de absorção capilar. 
Com a finalização do pré-condicionamento, os corpos-de-prova devem ter as laterais e o topo selados. A fim de evitar a troca de umidade dos corpos-de-prova com o ambiente durante o ensaio, e a penetração do vapor de água. Antes de iniciar o ensaio, os corpos-de-prova foram pesados em uma balança com precisão de $0,1 \mathrm{~g}$. Durante o ensaio, os corpos-de-prova cilíndricos tiveram o topo imerso em um recipiente com uma película de água de $3 \mathrm{~mm}$ durante 24 horas, com medições de aumento de massa nos intervalos de 10 minutos, 1, 4 e 24 horas. Ao final das 24 horas, os corpos-de-prova foram pesados para a análise da absorção de água e, em seguida, rompidos transversalmente para a verificação da altura da ascensão capilar. O objetivo deste ensaio foi verificar a ocorrência da colmatação dos poros nos concretos carbonatados e realcalinizados com as três soluções alcalinas estudadas, e compará-los ao de referência.

\subsubsection{ENSAIO DE ABSORÇÃO DE ÁGUA POR IMERSÃO E FERVURA}

O ensaio de absorção de água por imersão e fervura foi realizado de acordo com a norma NBR 9778 (ABNT, 2005). Este ensaio permitiu determinar a absorção de água, o índice de vazios e a massa específica dos corpos-de-prova de referência, carbonatados e realcalinizados com cada uma das soluções estudadas nesta pesquisa.

\subsubsection{DURABILIDADE DA REALCALINIZAÇÃO QUÍMICA}

A durabilidade da técnica de realcalinização química através da absorção e difusão de diferentes soluções alcalinas foi realizada através da comparação entre a velocidade de carbonatação do concreto não carbonatado e da recarbonatação dos concretos tratados através da RAQ. Este ensaio utilizou alguns dos corpos-de-prova de referência armazenados nas caixas com umidade e temperatura controlada e livre de gás carbônico (item 4.1.4.2).

A recarbonatação dos corpos-de-prova realcalinizados através da RAQ e a carbonatação dos corpos-de-prova guardados nas caixas foram realizadas conforme a carbonatação acelerada descrita anteriormente no item 4.3.2. As leituras das profundidades de carbonatação estavam previstas para ser feitas a cada 15 dias. No entanto, como a profundidade de recarbonatação dos corpos-de-prova realcalinizados não mostrava qualquer indício de avanço, a segunda medida foi realizada com 30 dias. Estas leituras da profundidade de carbonatação dos corpos-de-prova não carbonatados e a recarbonatação dos corpos-de-prova realcalinizados também foram realizadas conforme o descrito anteriormente no 4.3.1. 


\section{APRESENTAÇÃO E ANÁLISE DOS RESULTADOS}

A apresentação e a análise dos resultados a seguir visam interpretar as Variáveis Dependentes do item 4.1.2, expostas no Capítulo 4 - Metodologia do Experimento.

\subsection{EnSAios de Medidas Eletroquímicas}

Esta etapa da pesquisa busca responder, com o auxílio das medidas eletroquímicas, se os tratamentos de realcalinização são mesmo eficazes.

Esta etapa foi dividida em três fases: passivação (item 5.1.1), despassivação (item 5.1.2) e repassivação da armadura (item 5.1.3). Cada fase procurou avaliar eletroquimicamente a formação da película de passivação ao redor da armadura, a sua despassivação provocada pela carbonatação total do cobrimento, assim como a sua repassivação provocada pela chegada da frente de realcalinização através do cobrimento. Com o intuito de facilitar a observação das fases, foram elaborados gráficos para cada relação a/c e cura, como também para cada parâmetro eletroquímico avaliado.

Em todas as fases deste ensaio (passivação, despassivação e repassivação da armadura), as análises dos resultados de potencial de corrosão (Ecorr) foram realizadas de acordo com o descrito na Tabela 5.1, na qual o estado da armadura é classificado de acordo com a probabilidade de estar ocorrendo a corrosão na mesma.

Tabela 5.1. Critérios de avaliação da corrosão através de medidas de potencial de corrosão com eletrodo de cobre-sulfato de cobre (ASTM C876, 1991).

\begin{tabular}{cc}
\hline Ecorr $\left(\mathbf{m V}, \mathbf{C u} / \mathbf{S O}_{\mathbf{4}} \mathbf{C u}\right)$ & Probabilidade de corrosão \\
\hline$>-200$ & $<5 \%$ \\
\hline Entre -200 e--350 & $50 \%$ \\
\hline$<-350$ & $>95 \%$ \\
\hline
\end{tabular}

Os resultados de potencial de corrosão obtidos nas duas primeiras fases deste ensaio (passivação e despassivação da armadura) estão ilustrados no final da discussão do item 5.1.2 (Despassivação da Armadura no Interior do Concreto), de forma a facilitar a visualização do comportamento da armadura até a fase final da carbonatação acelerada. 
Os resultados da etapa de realcalinização são discutidos dentro do item "Repassivação da Armadura no Interior do Concreto", separados apenas quanto ao tipo de realcalinização realizada (RAE ou RAQ).

Os gráficos obtidos através da espectroscopia de impedância eletroquímica (EIE) foram mostrados e analisados ao final da discussão de cada fase do ensaio através de três diagramas: o de Nyquist (Impedância Real-Zreal pela Impedância ImagináriaZim), e pelos de Bode: diagrama de Ângulos de Fase pela Freqüência e da Impedância Total $(|\mathrm{Z}|)$ pela Freqüência . O enfoque dado às análises dos diagramas obtidos através da EIE foi de caráter qualitativo, uma vez que as suas análises quantitativas estão fora das possibilidades em relação ao equipamento e o software utilizado nesta pesquisa, conforme já abordado no item 4.3.3.3.

A espectroscopia de impedância eletroquímica possibilita a determinação da resistência física global de um determinado material em um dado meio, quanto maior a impedância do sistema $(Z)$ mais passivo será o sistema, ou seja, maior a restrição do eletrodo à passagem de corrente (Figura 5.1).

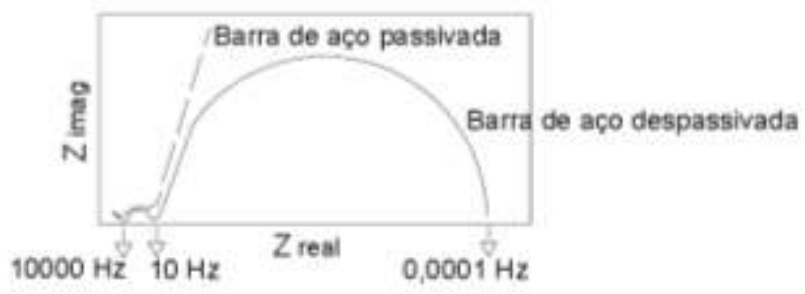

Figura 5.1. Espectros de impedância de concretos com barras de aço passivada e despassivada (Silva, 2006).

Nos diagramas de Nyquist, a seguir apresentados, os espectros obtidos vão apresentar características semelhantes quanto à formação dos arcos, tanto a altas freqüências, quanto a baixas freqüências. Estes arcos, independente da região de freqüência, se apresentaram incompletos, devido à freqüência estabelecida no equipamento, de $100 \mathrm{kHz}$ a $5 \mathrm{mHz}$. A estes arcos, está relacionada uma constante de tempo RC, representada por elementos de um circuito elétrico (resistor em paralelo a um capacitor).

Conforme descrito anteriormente no item 4.3.3.3, cada faixa de freqüência caracteriza uma parte da estrutura do concreto armado. Onde a região de baixa freqüência $(<1 \mathrm{~Hz})$ é utilizada para caracterizar a extensão da corrosão na superfície da armadura, a região de média frequiência (entre $10.000 \mathrm{~Hz}$ e $1 \mathrm{~Hz}$ ) é normalmente 
atribuída ao processo corrosivo e aos produtos de hidratação formados, e a região de alta freqüência $(>10.000 \mathrm{~Hz})$ deve-se às propriedades interfaciais do concreto.

\subsubsection{PASSIVAÇÃO DA ARMAdURA NO INTERIOR DO CONCRETO}

A determinação da passivação foi necessária para verificar o tempo necessário para a formação da mesma. Uma vez que a formação desta película ao redor da armadura não ocorre imediatamente com a concretagem das peças. De acordo com as bibliografias estudadas, é necessário aguardar um período de tempo para a camada de óxidos de ferro se formar ao redor da armadura. Este período pode demorar de 7 dias (Poursaee e Hansson, 2007) à quatro meses (Araujo et al, 2007a).

Nesta pesquisa, a formação da película de passivação só foi detectada após 3 meses e meio depois da moldagem dos corpos-de-prova. Pois foi apenas a partir deste período que o Potenciostato, utilizado para a verificação da espectroscopia de impedância eletroquímica (EIE), existente no laboratório, voltou da manutenção.

Porém, durante todo este período foram realizadas medidas periódicas de potencial de corrosão, as quais possibilitaram a constatação do aumento do potencial de corrosão (menos eletronegativo) das barras com o passar do tempo. Ao final do segundo mês, a maioria das barras já apresentava um potencial de corrosão classificado com probabilidade de $5 \%(>-200 \mathrm{mV})$, no entanto algumas permaneciam na faixa de incerteza do método (entre -200 e $-350 \mathrm{mV}$ ), com a probabilidade de corrosão de $50 \%$.

O potenciostato retornou ao laboratório cerca de 30 dias depois de obtidos os valores de potencial de corrosão citados anteriormente. Com o intuito de esclarecer a dúvida quanto ao real estado da armadura, no dia seguinte à chegada do equipamento foi dado início aos ensaios de EIE. No entanto, como estava demorando em torno de 40 minutos realizar a EIE em cada barra, ficou decidido que nesta fase o ensaio seria realizado apenas nos corpos-de-prova que apresentaram nos últimos dois meses um leve aumento no valor do potencial, embora seus valores de potencial ainda se mantivessem dentro da faixa de probabilidade de corrosão inferior a 5\%. Como esperado, os gráficos de EIE não deixaram qualquer dúvida quanto ao estado de passivação das armaduras, como pode ser observado nos gráficos da Figura 5.2 e do Apêndice A.

Nos resultados de EIE obtidos durante o período de passivação da armadura, é possível observar a ascensão da curva do gráfico de Nyquist, característico de uma barra passivada (Figura 5.2). 


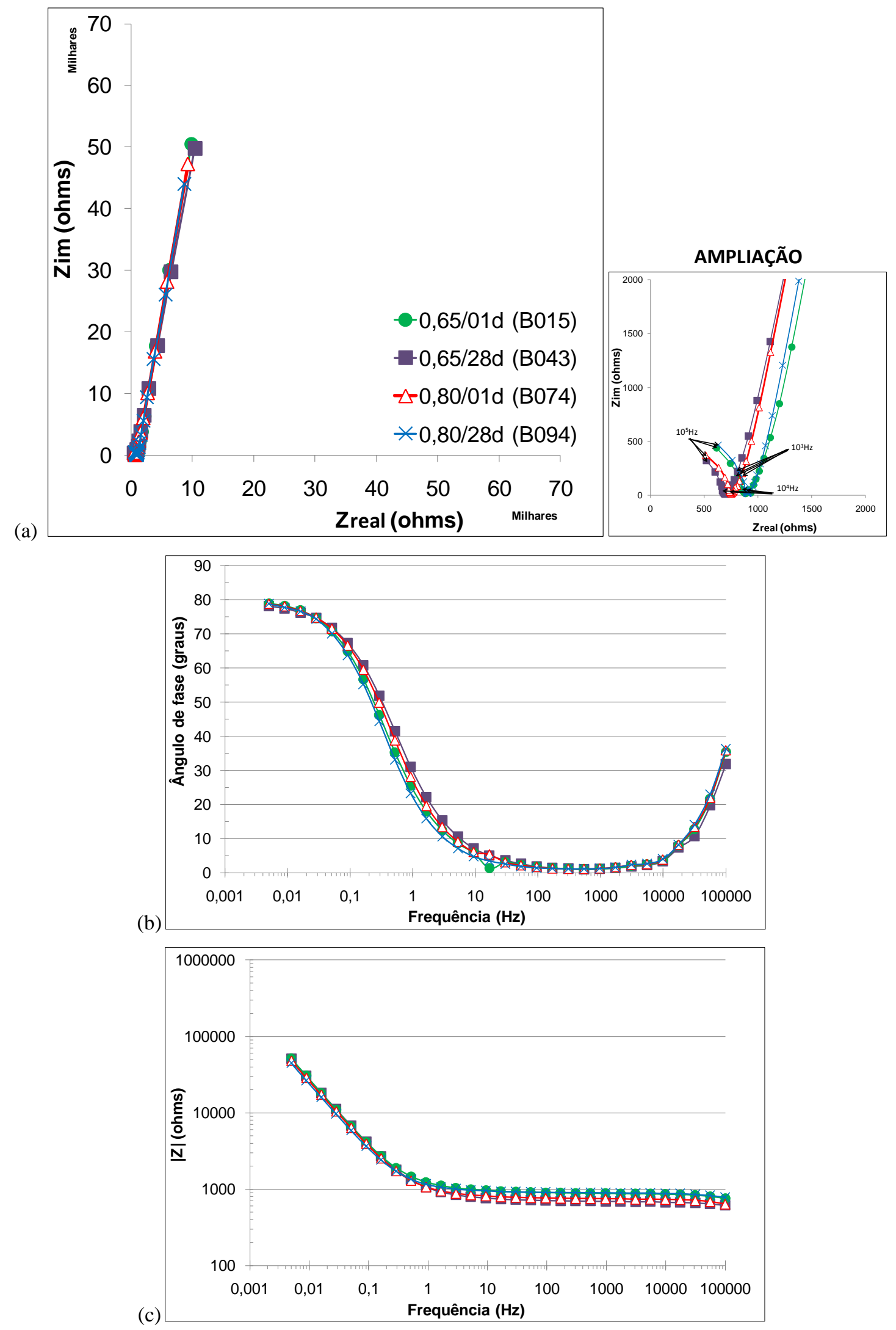

Figura 5.2. Evolução dos espectros de impedância obtidos em concretos com diferentes relações a/c $(0,65$ e 0,80$)$ e tempos de curas (01 e 28 dias) antes da carbonatação aos 3,5 meses de idade, com o número da barra a que se referem (Bxxx): (a) Diagrama de Nyquist, (b) e (c) Diagramas de Bode. 
É possível observar um mesmo comportamento em relação a todas as barras ilustradas. Iniciando pela formação do primeiro arco incompleto de Nyquist (na ampliação da Figura 5.2 (a)) na alta frequiência $\left(10^{5}\right.$ até $\left.10^{4} \mathrm{~Hz}\right)$. O qual fornece informações a respeito das características dielétricas da matriz de concreto.

Em relação ao processo de passivação na superfície da armadura, a sua observação é feita através da análise do último arco da curva de Nyquist localizado na região de baixa freqüência (menor que $10 \mathrm{~Hz}$ ). A formação da película de passivação é observada através dos altos valores de Zim da Figura 5.2(a). Qualitativamente a passivação da armadura é identificada pela ascensão constante da curva de Nyquist, ilustrada anteriormente na Figura 5.1, e sem nenhum indício de fechamento do arco nas baixas freqüências (menor que $10 \mathrm{~Hz}$ ). Na Figura 5.2 (c) a grande inclinação de $|\mathrm{Z}|$ para as frequiências abaixo de $10 \mathrm{~Hz}$, chega ao pico máximo de $51.400 \mathrm{ohms}$ na freqüência de $5 \mathrm{mHz}$, ou seja bastante resistivo à passagem de corrente elétrica.

Na Figura 5.2 (b) é possível observar que os altos valores de ângulo de fase máximos na baixa freqüência no gráfico de Bode, embora não estivessem bem definidos, todos ficaram na faixa de $78^{\circ}$, bem próximo ao valor máximo de $90^{\circ}$, quando o comportamento da célula é puramente capacitivo (Aoki, 2008).

Uma vez confirmada a formação da película de passivação, os corpos-deprova foram colocados na câmara de carbonatação acelerada até que fosse constatada a total carbonatação do cobrimento do concreto, como também a despassivação das armaduras.

\subsubsection{DESPASSIVAÇÃO DA ARMADURA NO INTERIOR DO CONCRETO}

Os corpos-de-prova com apenas um dia de cura foram os primeiros a terem o seu cobrimento totalmente carbonatado com a concentração de $10 \%$ de $\mathrm{CO}_{2}$. Os corpos-de-prova de relação a/c 0,80 demoraram 5 semanas para carbonatar totalmente, os de a/c 0,65 demoraram 6 semanas. Os corpos-de-prova de tempo de cura de 28 dias demoraram um pouco mais, permanecendo durante 9 semanas no interior da câmara de carbonatação os corpos-de-prova de a/c 0,80 e 16 semanas os de a/c 0,65.

A verificação da profundidade de carbonatação foi realizada através da fratura de corpos-de-prova moldados para esta finalidade (Figura 5.3), chamados de "irmãos" (corpos-de-prova também armados) dos que foram realcalinizados posteriormente, seguida da aspersão de uma solução alcoólica de fenolftaleína. 
(a)

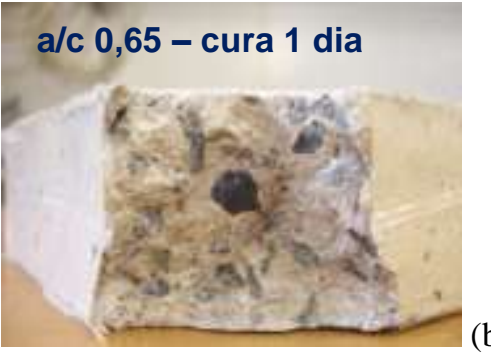

(c)

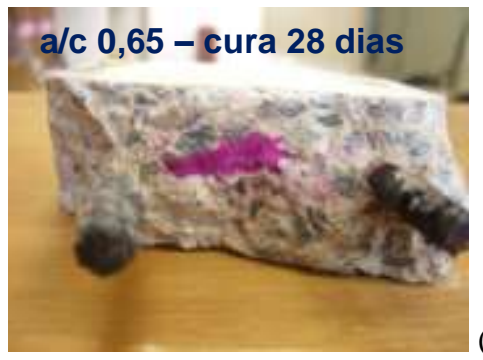

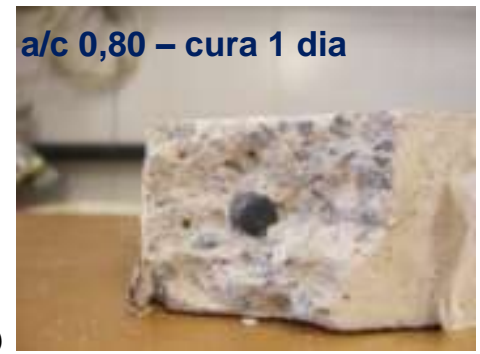

(d)

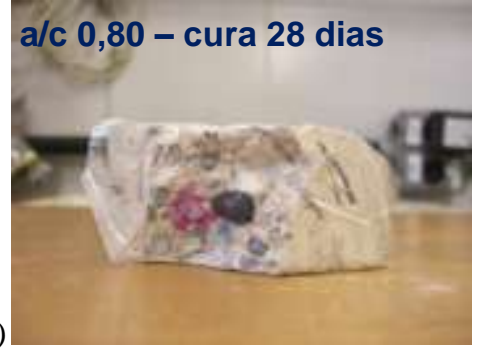

Figura 5.3. Corpos-de-prova "irmãos" utilizados nos ensaios eletroquímicos totalmente carbonatados.

A determinação da despassivação da armadura através do potencial de corrosão somente foi realizada quando constatada a carbonatação do cobrimento dos corpos-de-prova "irmãos", através da aspersão de solução de fenolftaleína. As medidas de potencial de corrosão foram obtidas logo após a retirada dos corpos-de-prova da câmara de carbonatação acelerada sem a saturação dos mesmos. Ao verificar a alta eletronegatividade dos potenciais de corrosão, menor do que $-350 \mathrm{mV}$, indicando um potencial de probabilidade de corrosão de $95 \%$, então era dado início aos ensaios de EIE, para determinar o estado da armadura, de forma a corroborarem com os resultados de potencial (Figura 5.4). 


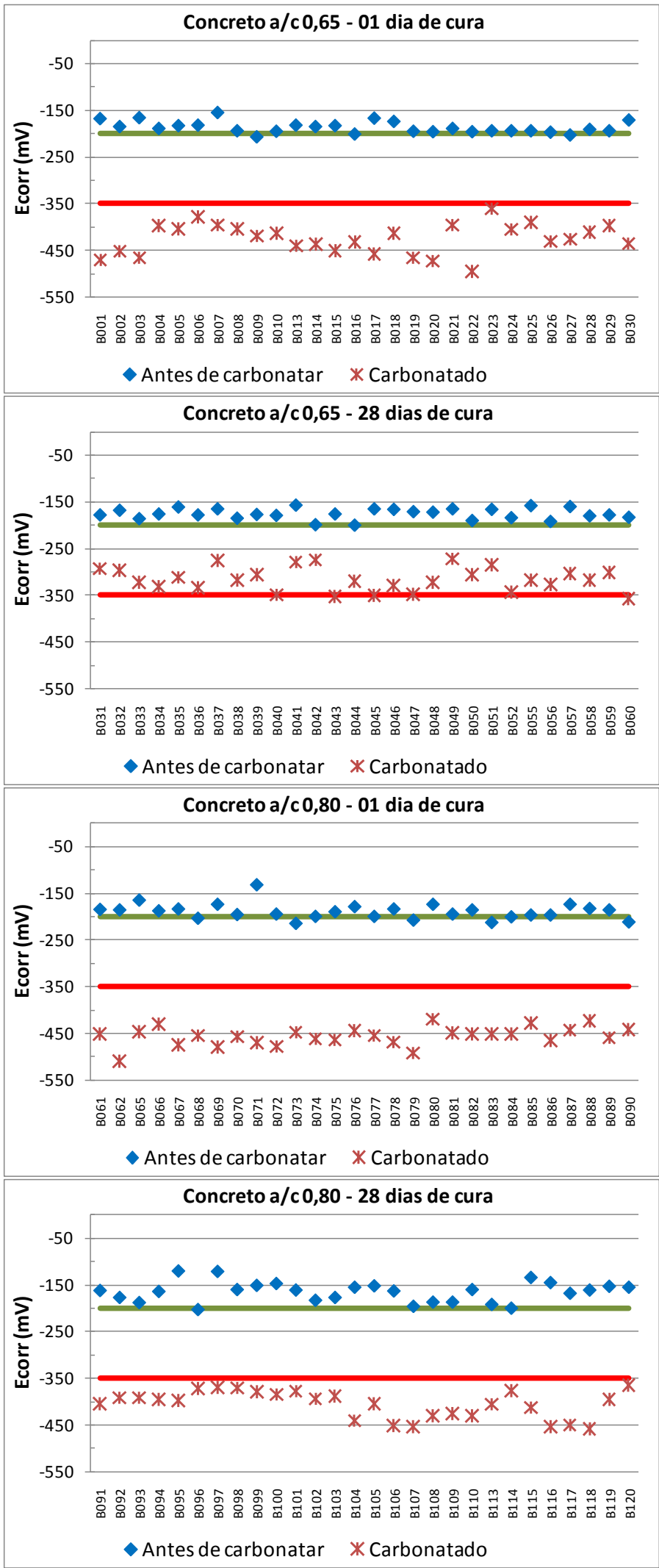

Figura 5.4. Resultados de potencial de corrosão (Ecorr) antes de iniciar a carbonatação acelerada (na idade de 3,5 meses) e depois de carbonatado todo o cobrimento da armadura (armaduras despassivadas). Nas duas situações, os corpos-de-prova tinham acabado ser retirado de uma câmara que se encontrava na umidade relativa de $75 \pm 5 \%$. 
A partir desta fase, o ensaio de leitura de EIE foi realizado em todas as barras estudadas. Entretanto, como o universo de amostras desta parte da pesquisa é bastante amplo (112 barras no total), apenas um espectro de impedância de cada tipo de a/c e cura foi apresentado nesta discussão dos resultados, salvo algum espectro que venha a ser necessário comentar. Porém, ressalta-se que todos os resultados poderão ser encontrados no Apêndice A deste trabalho.

Mesmo os resultados de Ecorr (Figura 5.4) das barras de concreto a/c 0,65 com 28 dias de cura apresentando uma probabilidade de corrosão de 50\%, os ensaios de EIE não deixaram dúvidas quando a despassivação das armaduras.

Como é possível observar nos espectros da Figura 5.5 (a), mais uma vez não foi possível obter o arco completo do primeiro e do último semicírculo do gráfico de Nyquist, uma vez que é difícil e demorado. Primeiramente, devido à faixa de frequiência que se trabalhou (de $10^{5} \mathrm{~Hz}$ até $5 \mathrm{mHz}$ ), mas também devido ao tempo de ensaio para a obtenção das medidas de impedância eletroquímica até a baixa freqüência de $5 \mathrm{mHz}$ que varia entre 20 e 90 minutos para cada barra. Devido a estas dificuldades, para obter o último semicírculo do gráfico de Nyquist, após a despassivação da armadura, utilizou-se uma ferramenta disponível no software "PowerSine" para realizar a extrapolação deste último arco incompleto, o que possibilita estimar valores de resistência de polarização (Rp). No entanto, mesmo sem a utilização do recurso de extrapolação é possível observar a tendência de fechamento do arco na amplitude do Zreal entre as frequiências de $10 \mathrm{~Hz}$ e $5 \mathrm{mHz}$, que é característico em barras despassivadas (Figura 5.1).

No diagrama de Bode da Figura 5.5(c), o processo corrosivo é verificado pela mudança de inclinação do $|\mathrm{Z}|$ em função da freqüência, que na Figura 5.2 (c) chegava a ordem de 51.000 ohms, ou seja, agora se encontra bem menos resistivo à passagem de corrente na baixa freqüência. Na Figura 5.5 (b) os ângulos de fase obtidos são bem menores do que os encontrados na Figura 5.2(b), que eram de aproximadamente $80^{\circ}$, e agora entre $23^{\circ}$ e $13^{\circ}$, característico de uma barra em estado de corrosão. 


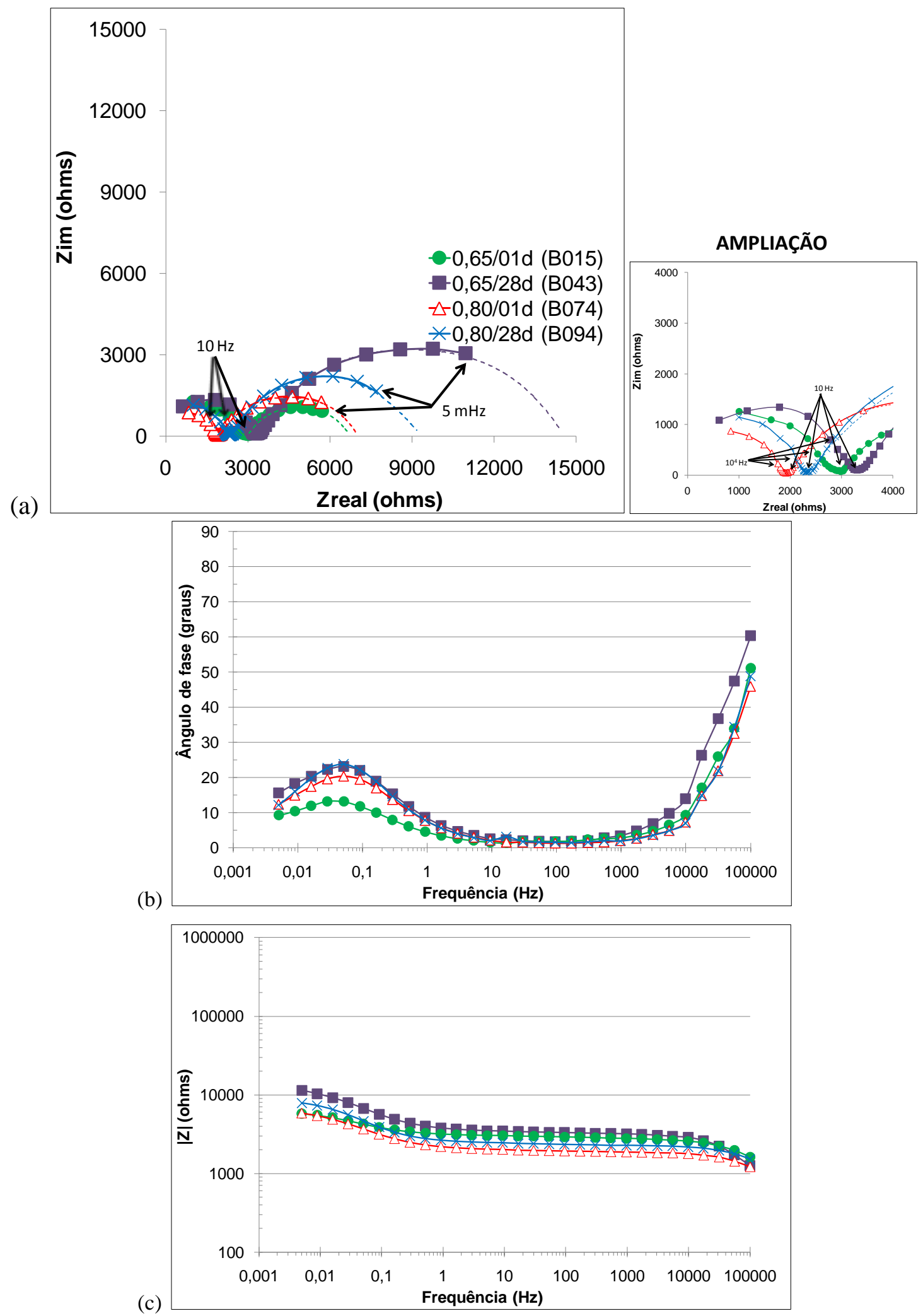

Figura 5.5. Evolução dos espectros de impedância obtidos em concretos com diferentes relações a/c $(0,65$ e 0,80$)$ e tempos de curas $(01$ e 28 dias) totalmente carbonatados, com o número da barra a que se referem (Bxxx): (a) Diagrama de Nyquist, (b) e (c) Diagramas de Bode. 
Outro dado importante é o deslocamento das curvas de Nyquist (Figura 5.5 (a)) para a direita. Este deslocamento indica o aumento da resistência ôhmica de cada um dos concretos, onde o concreto $0,65 / 28$ d é o de maior resistência ôhmica, seguido do $0,65 / 01 \mathrm{~d}$, sendo o concreto de menor relação água/cimento $(0,80)$ com o menor tempo de cura (1 dia) justamente o de menor resistência ôhmica.

Com a comparação da ampliação da Figura 5.2 (a) com a da ampliação da Figura 5.5 (a), é possível observar o aumento da resistência ôhmica com a carbonatação. A carbonatação reduz a porosidade do concreto devido a formação de carbonato de cálcio nos poros do concreto. O carbonato de cálcio formado tem um volume maior do que o hidróxido de cálcio, que estava originalmente nos poros. Desta maneira ocorre a redução da porosidade, e a resistência à passagem de corrente reduz, ou seja, a resistência ôhmica, que é praticamente a resistividade elétrica, diminui.

Após a confirmação da despassivação da armadura nos concretos carbonatados através dos ensaios de potencial de corrosão e de EIE, foi dado início aos processos de realcalinização, tanto eletroquímicos (RAE), quanto por imersão em solução alcalina (RAQ).

\subsubsection{REPASSIVAÇÃO DA ARMADURA NO INTERIOR DO CONCRETO}

A repassivação da armadura no interior do concreto ocorreu de duas maneiras: através da indução de corrente (realcalinização eletroquímica - RAE) e sem a indução de corrente, somente através da imersão dos corpos-de-prova nas soluções alcalinas, promovendo a absorção e a difusão das soluções alcalina para o interior do concreto carbonatado (realcalinização química - RAQ).

A identificação da recuperação da película de passivação foi realizada a partir da obtenção de valores de potencial de corrosão menos eletronegativo (> -200 $\mathrm{mV})$. Além da identificação da curva de Nyquist sem a formação do último arco no ensaio de EIE.

\subsubsection{REALCALINIZAÇÃO ELETROQUÍMICA (RAE)}

Os corpos-de-prova realcalinizados eletroquimicamente permaneceram em tratamento durante 14 dias sob uma corrente de $24 \mathrm{~mA}$ (Figura 5.6), respeitando o limite definido pela norma européia a EN 14038-1 (CEN, 2005) de $1 \mathrm{~A} / \mathrm{m}^{2}$. 

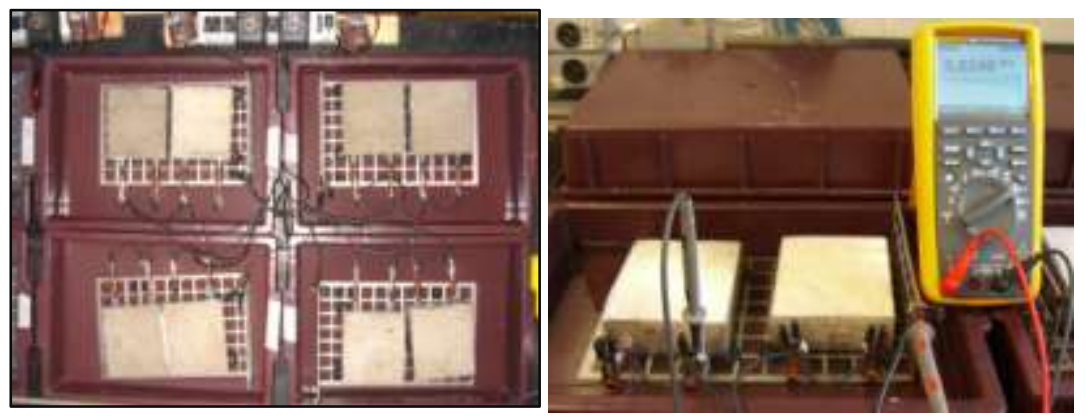

Figura 5.6. Realcalinização eletroquímica dos corpos-de-prova carbonatados.

Nos últimos dois dias de tratamento dos corpos-de-prova de cura de 1 dia foi observada a cristalização de sais na superfície dos mesmos, como também o aparecimento de manchas amareladas. A cristalização do sal ocorreu tanto na superfície de contato com a solução alcalina de carbonato de sódio quanto na superfície oposta à solução. Entretanto, observou-se que foi justamente na superfície oposta à superfície de contato com a solução alcalina que a maior quantidade de cristais foram formados (Figura 5.7).

(a)

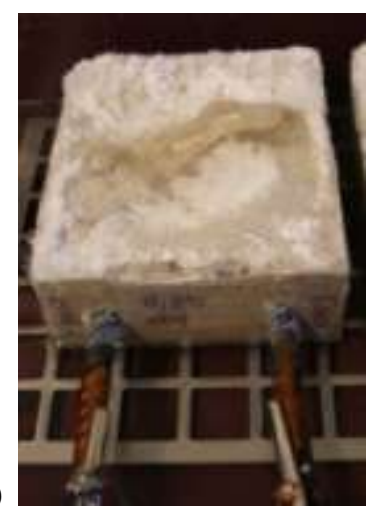

(b)

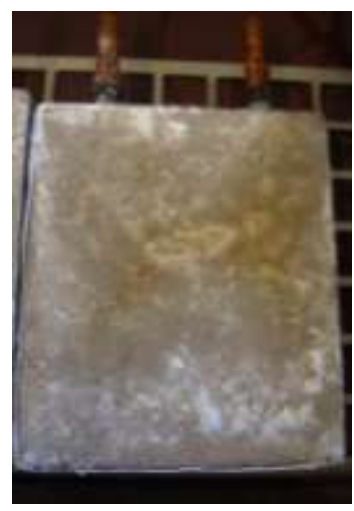

Figura 5.7. Concretos realcalinizados eletroquimicamente em solução de $\mathrm{Na}_{2} \mathrm{CO}_{3}$ na concentração de $1 \mathrm{M}$, que depois de 12 dias de tratamento apresentaram a cristalização de sal na sua superfície: (a) corpo-de-prova de a/c 0,80 e cura de 1 dia; (b) corpos-deprova de a/c 0,65 e cura de 1 dia.

A cristalização de sal na superfície de contato com a solução do corpo-deprova ocorreu devido à concentração de sal na solução. No entanto, a maior quantidade de sal observada na superfície oposta à de contato com a solução. É provável que este comportamento seja a sinergia de dois fatores: o primeiro em razão da polarização positiva a qual a barra está submetida, agindo de modo a repelir os íons positivos da solução $\left(\mathrm{Na}^{+}\right)$em direção a superfície oposta à de contato; e o segundo em razão dos íons concentrados na superfície oposta à de contato estarem em contato com o ar, sendo assim cristalizados em maior volume do que na superfície de contato, a qual está imersa na solução alcalina. Ou seja, como a superfície oposta está úmida, porém, não saturada 
como a superfície de contato, é possível que este seja o motivo pelo qual o sal tenha se cristalizado em maior quantidade nesta superfície.

Ao final do período de duas semanas de tratamento, os circuitos elétricos da RAE foram removidos, e então realizadas as primeiras medidas de potencial de corrosão. As primeiras leituras, com os corpos-de-prova ainda saturados, mostraram potenciais excessivamente eletronegativos. Porém, com a secagem durante 24 horas em estufa ventilada à $40^{\circ} \mathrm{C}$ e a posterior manutenção da umidade em caixas com $75 \%$ de umidade relativa por mais seis dias, as leituras seguintes mostram um aumento do potencial para a região de probabilidade de corrosão de 50\% (Figura 5.8). Ou seja, um potencial mais eletropositivo do que os obtidos ao final da carbonatação acelerada mostrados na Figura 5.4. É provável que neste momento o aumento do potencial de corrosão tenha ocorrido em razão da secagem dos corpos-de-prova.

As leituras seguintes foram sendo realizadas mensalmente com os corposde-prova secos, até o tratamento de realcalinização eletroquímica completar 1 ano. Durante todo o período de verificação da reconstituição da película de passivação, os corpos-de-prova permaneceram em condições de temperatura e umidade iguais às das fases de passivação e despassivação (carbonatação), com $23 \pm 3^{\circ} \mathrm{C}$ e $75 \pm 5 \%$. Nos gráficos da Figura 5.9 é possível observar, em alguns casos, uma evolução muito pequena do potencial de corrosão de 6 meses a 1 ano após a finalização da RAE. Em todas as situações, o potencial tornou-se um pouco mais eletropositivo com o passar do tempo, demonstrando uma tendência da diminuição da probabilidade de corrosão de $50 \%$ para 5\%. Entretanto, ainda assim, não foi possível ser conclusivo em relação a repassivação da armadura após 1 ano de finalizado o tratamento, através das medidas de potencial de corrosão, para todas as barras estudadas.

Os gráficos da Figura 5.9 indicam que o aumento dos valores de potencial de corrosão, assim como o tempo de repassivação, com a técnica de realcalinização eletroquímica depende principalmente da solução alcalina utilizada.

A solução de hidróxido de cálcio foi a única que depois de 1 ano apresentou a probabilidade de corrosão de $5 \%$ para todas as curas e relações água/cimento estudadas. A solução de $\mathrm{KOH}$ foi a segunda melhor, quando levamos em consideração o potencial de corrosão, seguida da $\mathrm{Na}_{2} \mathrm{CO}_{3}$. 


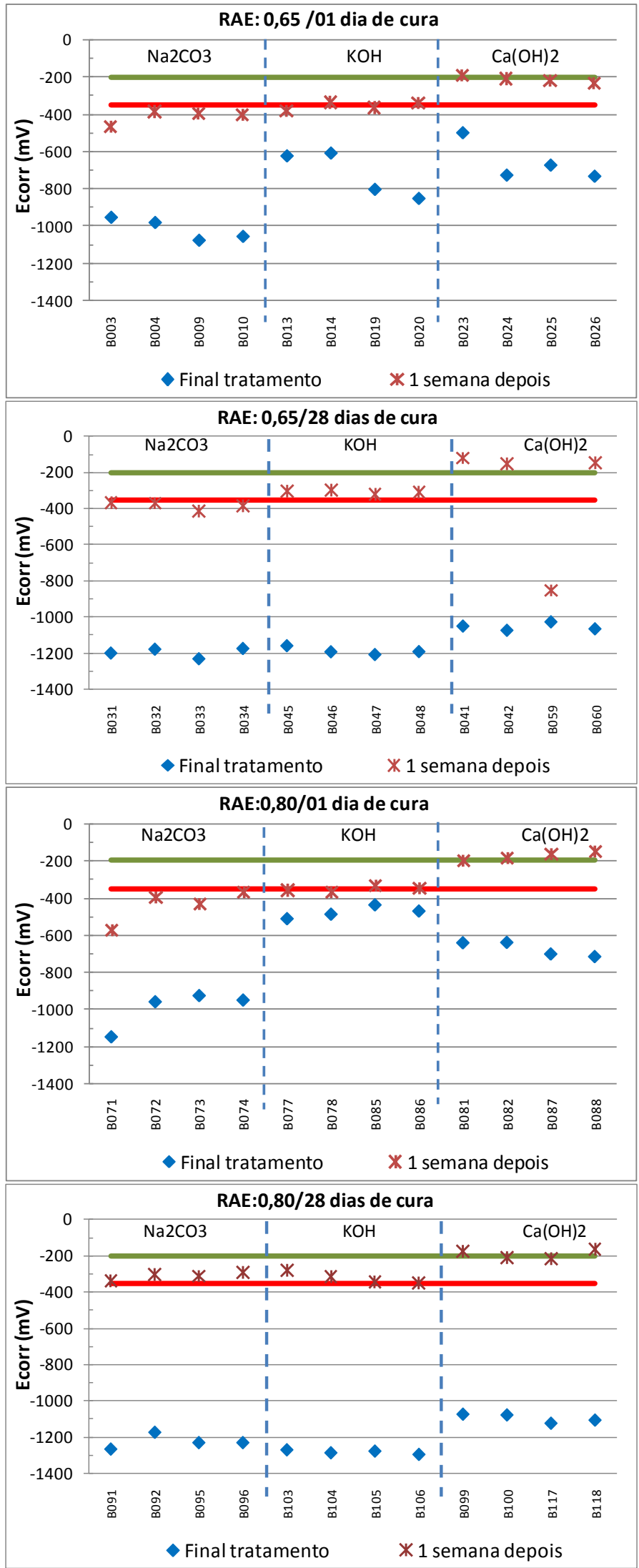

Figura 5.8. Leituras de potencial de corrosão nas barras dos corpos-de-prova realcalinizados eletroquimicamente $\operatorname{logo}$ após a finalização do tratamento ainda saturados, e depois de uma semana secos e mantidos em uma caixa com umidade de $75 \pm 5 \%$. 

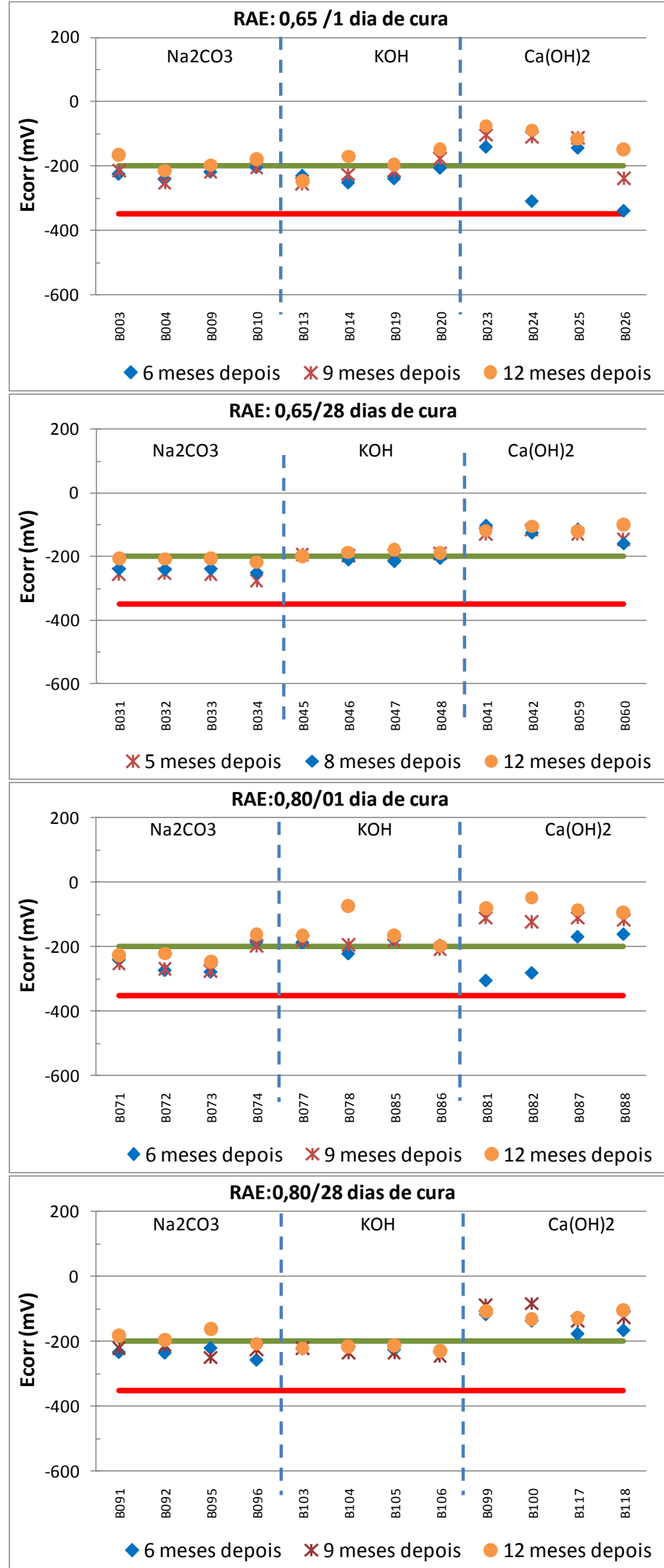

Figura 5.9. Leituras de potencial de corrosão nas barras dos corpos-de-prova realcalinizados eletroquimicamente, após 6, 9 e 12 meses da finalização do tratamento. 
A solução de hidróxido de potássio no concreto de a/c 0,65 e cura de 1 dia foi eficaz para a maioria das barras, restando apenas uma com um potencial de corrosão inferior a $-200 \mathrm{mV}$. Já para a relação a/c 0,80 e cura de 28 dias todas as barras tiveram um potencia de corrosão baixo do potencial de $-200 \mathrm{mV}$, ou seja, ainda na faixa de $50 \%$ de probabilidade de corrosão. As barras dos demais concretos imersos na solução de $\mathrm{KOH}$, conseguiram atingir a probabilidade de corrosão de 5\%, sendo eficaz a utilização da solução para a reconstituição da película de passivação.

A solução de carbonato de sódio foi a menos eficaz, pois em raros momentos conseguiu-se obter um potencial de corrosão acima de $-200 \mathrm{mV}$.

Quando a finalização do tratamento completou duas semanas foram realizadas as primeiras medidas de EIE. A partir dessas medidas foi comprovado o comportamento observado nas medidas de potencial de corrosão, no qual, embora as armaduras estivessem imersas em um concreto totalmente realcalinizado (Figura 5.10), os gráficos de impedância das barras mostraram as mesmas ainda despassivadas (Figura 5.11 a Figura 5.13).
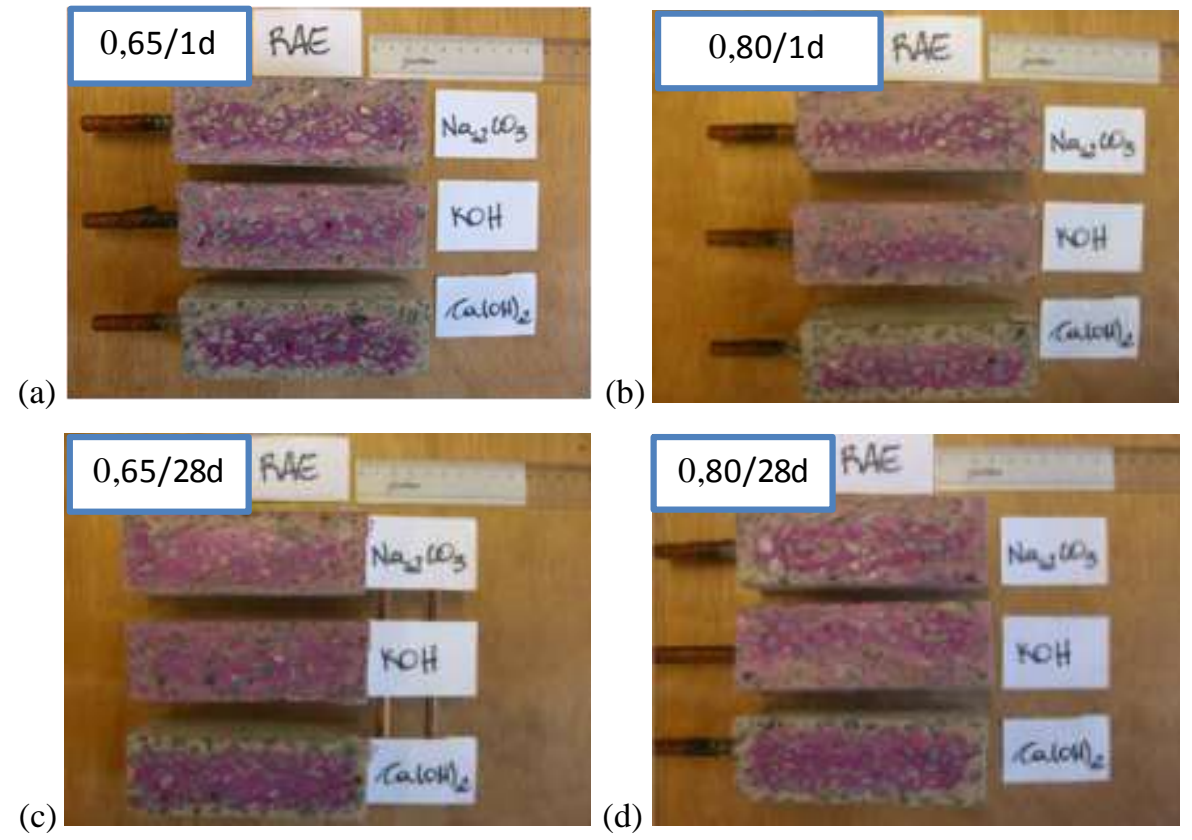

Figura 5.10. Corpos-de-prova realcalinizados eletroquimicamente: (a) a/c 0,65 com 1 dia de cura; (b) a/c 0,80 com 1 dia de cura; (c) a/c 0,65 com 28 dias de cura; (d) a/c 0,80 com 28 dias de cura.

No entanto, assim como observado nas medidas de potencial de corrosão, com o tempo foi verificada a eficácia da técnica, com ainda mais consistência do que as obtidas com o Ecorr. Da Figura 5.11 à Figura 5.13 é possível verificar que, com 9 meses depois de finalizado o tratamento, a corrosão da armadura já apresentava uma atividade 
passiva, embora os potenciais de corrosão mostrassem as barras ainda na probabilidade de corrosão de $50 \%$.

Como todos os corpos-de-prova se encontravam confinados em uma câmara com umidade e temperatura controlada, em $75 \pm 5 \%$ e $23 \pm 3^{\circ} \mathrm{C}$ respectivamente, durante todo o período de repassivação das armaduras, nos resultados de EIE é possível observar nas ampliações das Figura 5.11 à Figura 5.13, o deslocamento das curvas de Nyquist na idade de 15 dias para a idade de 9 meses para a direita, indicando um aumento da resistência ôhmica do material à passagem da corrente elétrica ao longo do tempo. Nestas Figuras, também é possível observar o aumento da inclinação da reta, indicando a passivação da armadura. Nos diagramas de Bode, o ângulo de Fase na baixa freqüência aumenta com o tempo, assim como o módulo de $\mathrm{Z}$, indicando a passivação da armadura. Em relação às soluções alcalinas estudadas, todas apresentaram para esta técnica uma realcalinização eficaz, propiciando para as regiões de baixa freqüência: uma grande inclinação no diagrama de Nyquist e de Bode $|Z|$, assim como altos ângulos de fase. As curvas referentes à solução de hidróxido de cálcio apresentaram um deslocamento nas regiões de média e de baixa freqüência, ou um pequeno arco indutivo. 

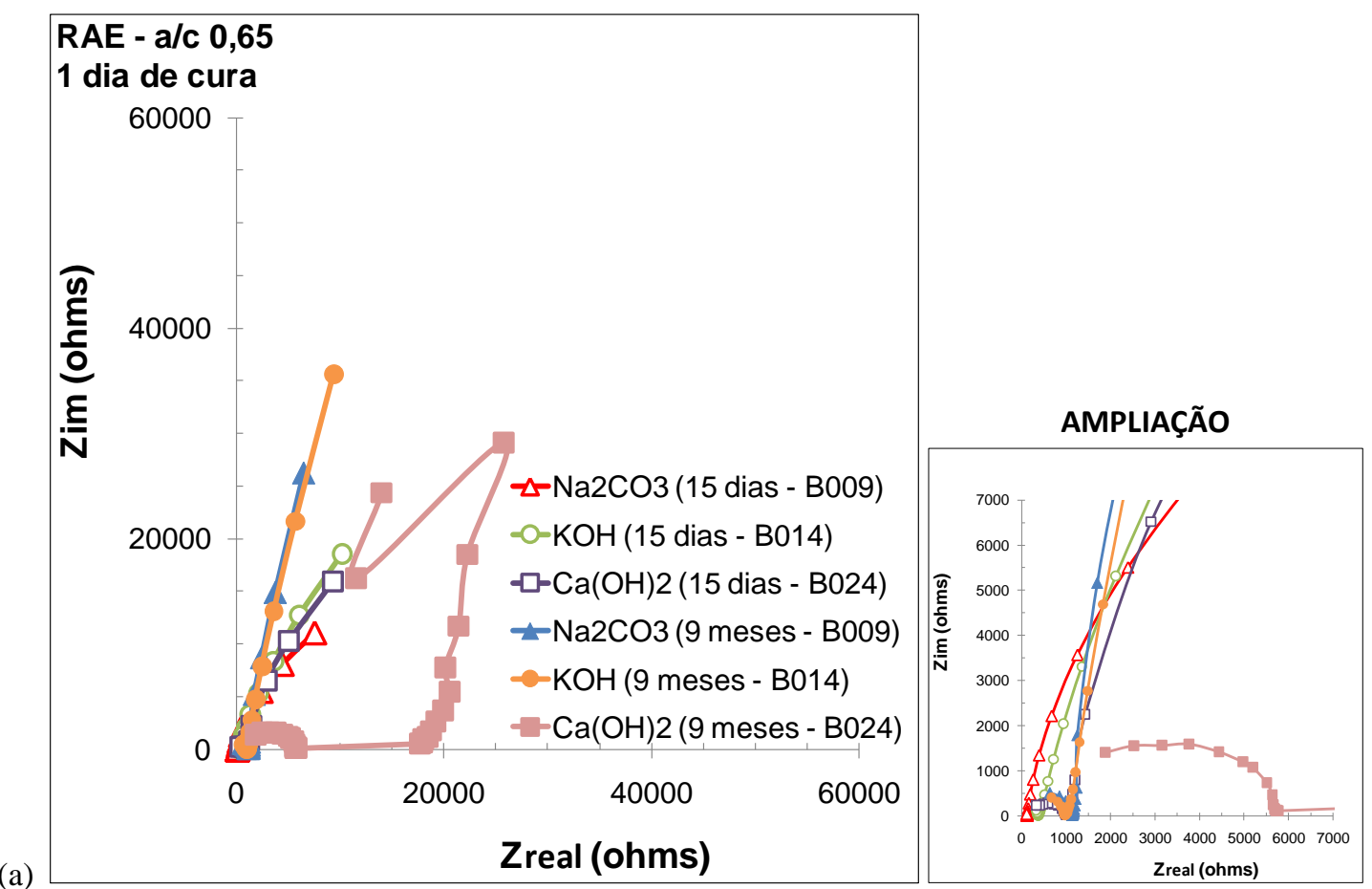

(a)

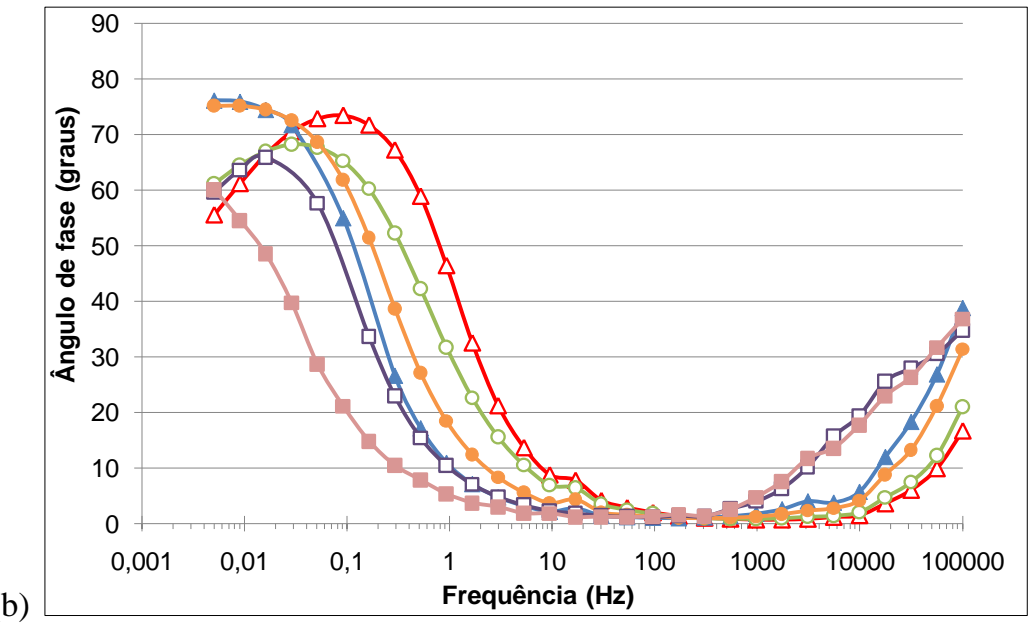

(b)

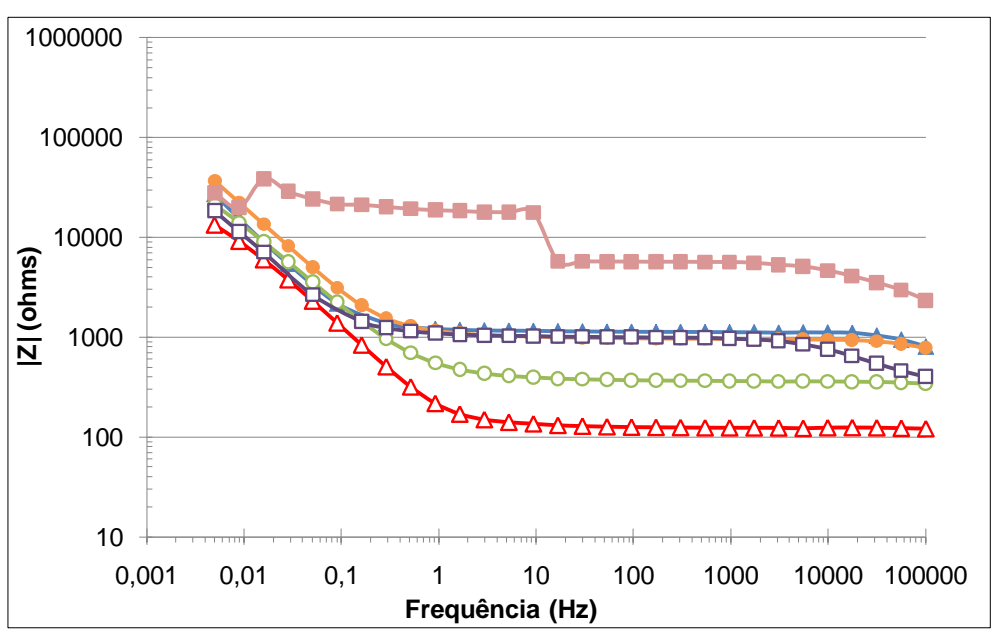

Figura 5.11. Evolução dos espectros de impedância obtidos nos concretos de relação a/c 0,65 e tempo de cura de 1 dia, nas idades de duas semanas depois de finalizado o tratamento de RAE e de 9 meses, com o número da barra a que se referem (Bxxx): (a) Diagrama de Nyquist, (b) e (c) Diagramas de Bode. 

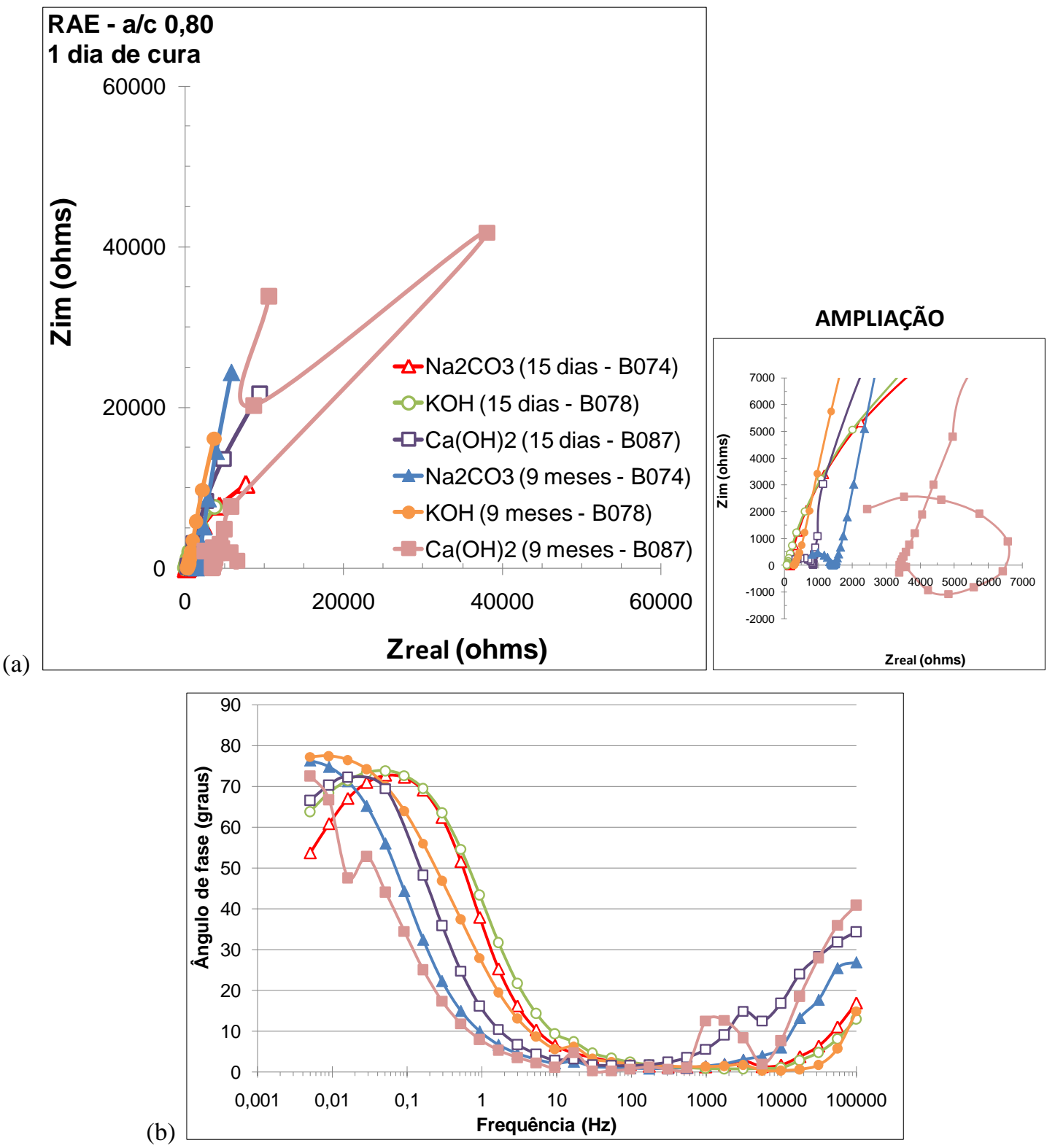

(b)

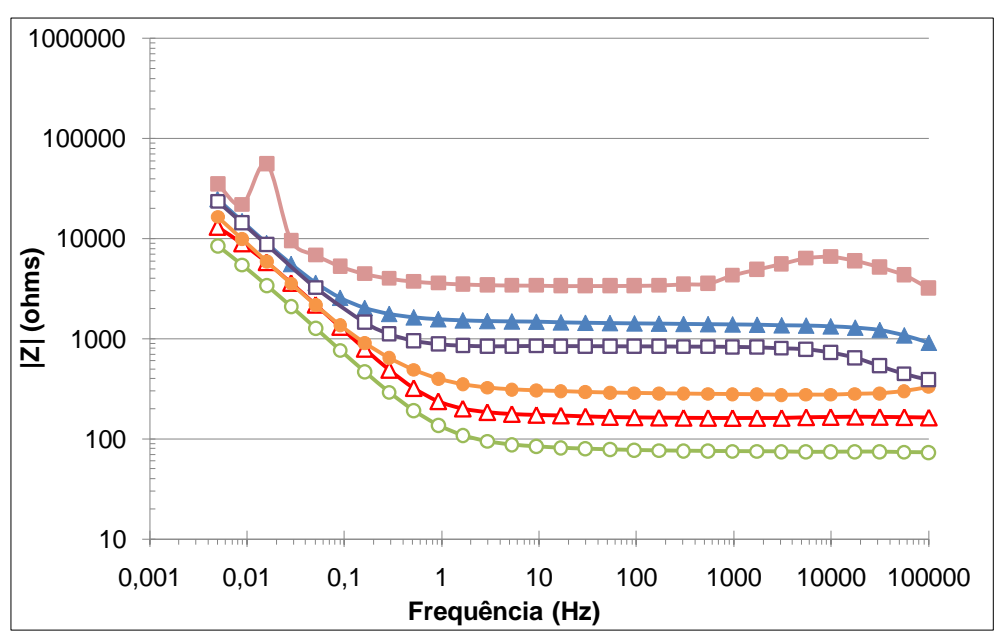

Figura 5.12. Evolução dos espectros de impedância obtidos nos concretos de relação a/c 0,80 e tempo de cura de 1 dia, nas idades de duas semanas depois de finalizado o tratamento de RAE e de 9 meses, com o número da barra a que se referem (Bxxx): (a) Diagrama de Nyquist, (b) e (c) Diagramas de Bode. 

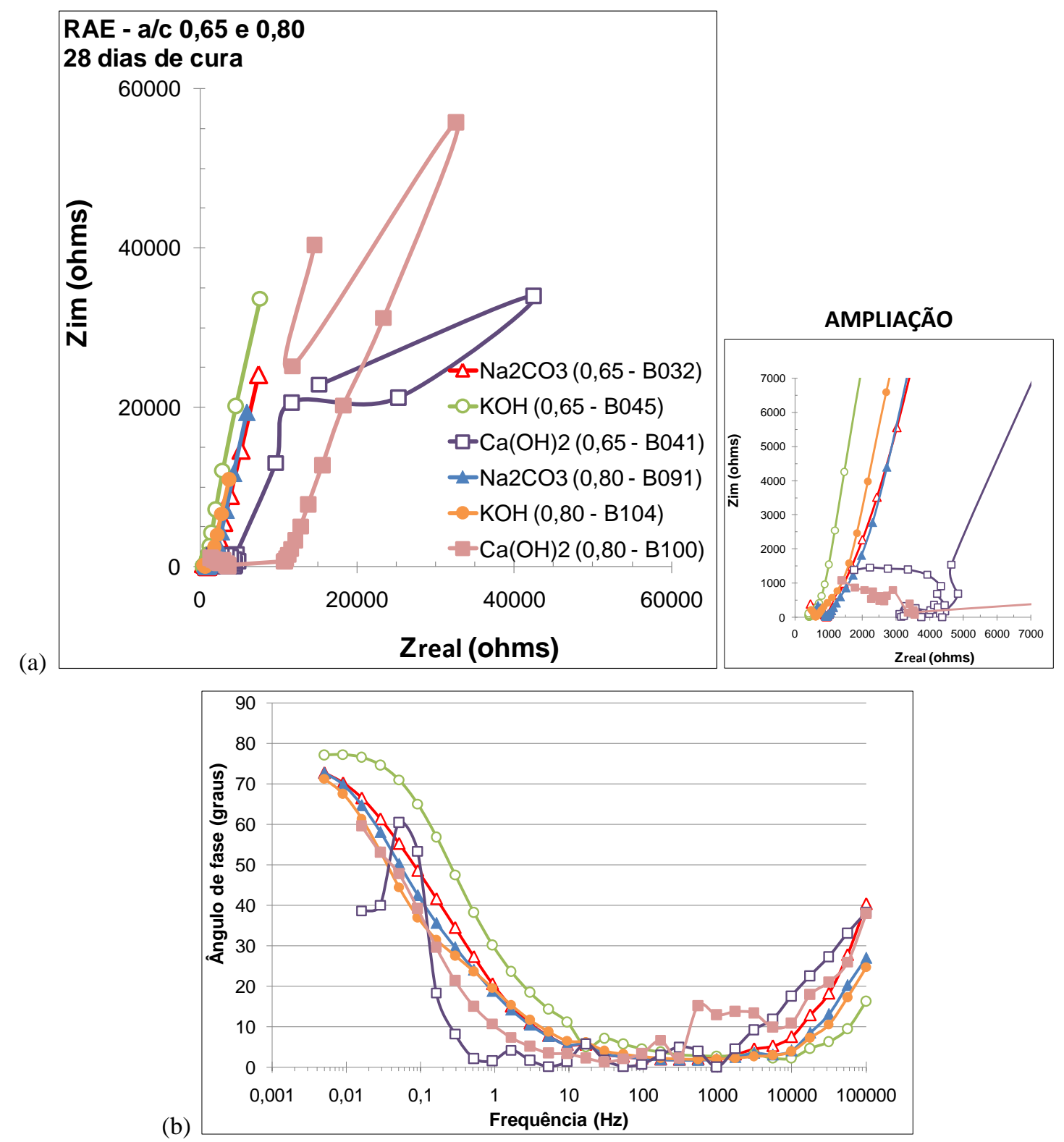

(b)

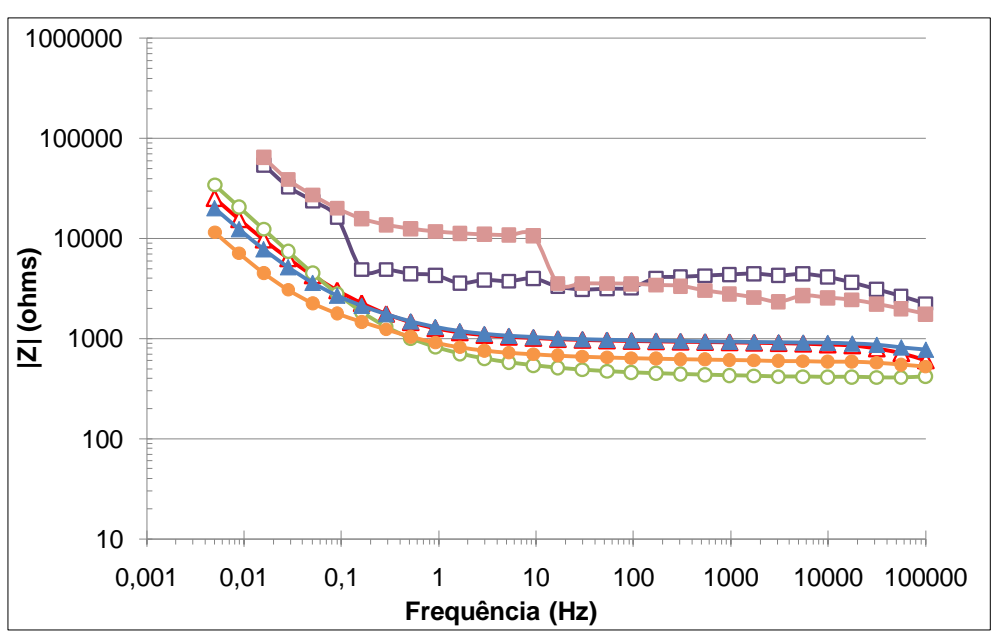

Figura 5.13. Evolução dos espectros de impedância obtidos nos concretos de relação a/c 0,65 e 0,80 e tempo de cura de 28 dias, 9 meses depois de finalizado o tratamento de RAE, com o número da barra a que se referem (Bxxx): (a) Diagrama de Nyquist, (b) e (c) Diagramas de Bode. 


\subsubsection{REALCALINIZAÇÃO QUÍMICA POR ABSORÇÃO E DIFUSÃO DE SOLUÇÕES ALCALINAS (RAQ)}

Conforme descrito anteriormente, a RAQ consistiu apenas na imersão dos corpos-de-prova em diferentes soluções alcalinas: carbonato de sódio, hidróxido de potássio e hidróxido de cálcio (Figura 5.14), sem a aplicação de corrente. Para acelerar o processo de absorção das soluções foi realizado o procedimento de ciclagem, no qual os corpos-de-prova permaneciam 2 dias imersos nas soluções e 3 dias em estufa ventilada a $40^{\circ} \mathrm{C}$.

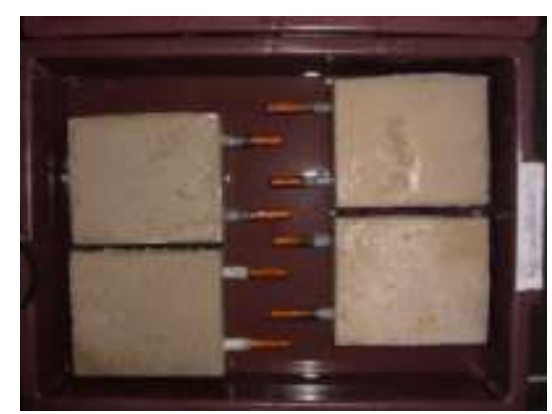

Figura 5.14. Corpos-de-prova durante a realcalinização química por absorção e difusão.

No entanto, ao final dos primeiros 14 dias de tratamento também foi observada na RAQ a cristalização de sais na superfície dos corpos-de-prova em contato com a solução alcalina, porém, em quantidade bem menor à observada na RAE (Figura 5.7), conforme ilustra a Figura 5.15.

(a)

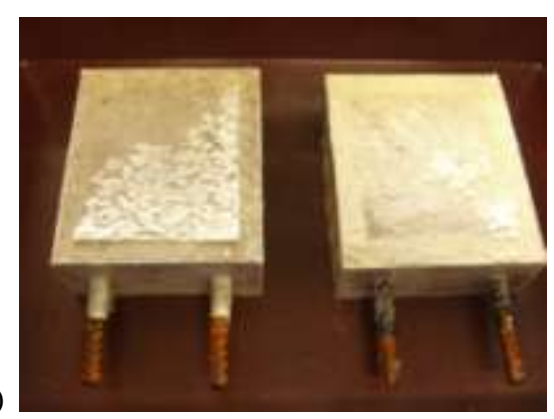

(b)

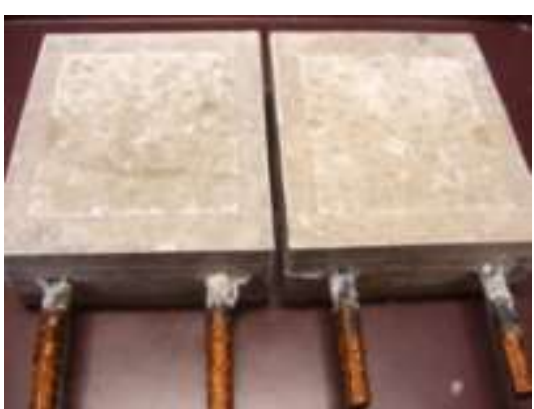

Figura 5.15. Sal cristalizado nos corpos-de-prova realcalinizado por absorção e difusão em diferentes soluções alcalinas: (a) solução de $1 \mathrm{M}$ de $\mathrm{Na}_{2} \mathrm{CO}_{3}$ e (b) solução de $2,5 \mathrm{M}$ de $\mathrm{KOH}$.

Outro comportamento observado na RAQ ao se completar 3 semanas de tratamento, foi a degradação da pasta de cimento em algumas relações a/c imersas na solução de carbonato de sódio (Figura 5.16). Os corpos-de-prova de relação a/c 0,80 com 1 e 28 dias de cura e o de relação a/c 0,65 com apenas 1 dia de cura sofreram deterioração da camada de cobrimento, perdendo a pasta e ficando o agregado exposto. 
(a)
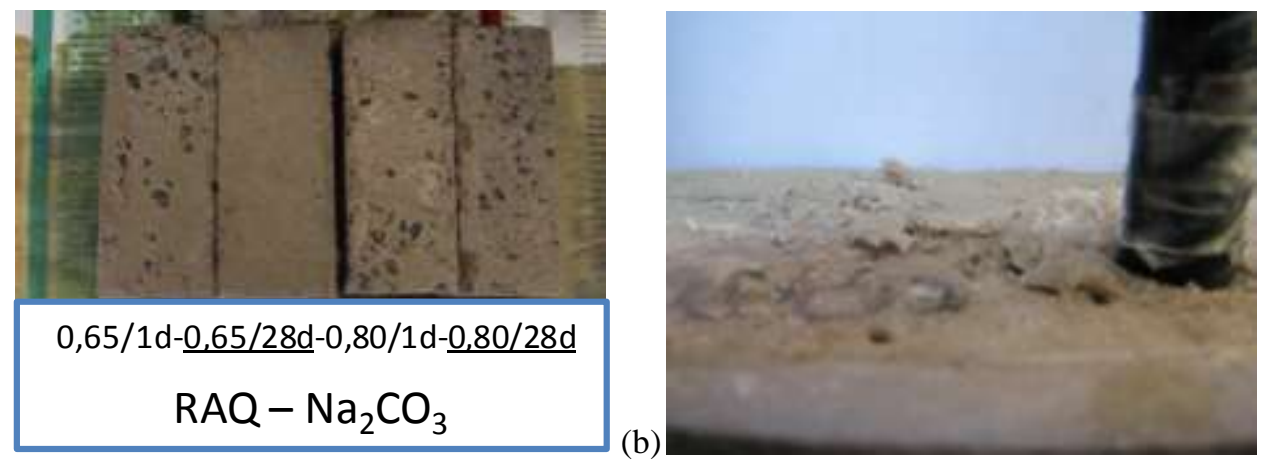

Figura 5.16. Deterioração da pasta de cobrimento observada nos corpos-de-prova durante a realcalinização química na solução de $\mathrm{Na}_{2} \mathrm{CO}_{3}$. (a) corpos-de-prova de relação a/c 0,65 com 1 e 28 dias de cura e relação a/c 0,80 com 1 e 28 dias de cura, e apenas o de a/c 0,65 com 28 dias de cura não apresentou degradação. (b) detalhe do destacamento próximo à armadura.

É provável que esta deterioração do cobrimento tenha ocorrido em razão da elevada alcalinidade da solução de $\mathrm{Na}_{2} \mathrm{CO}_{3}$ empregada durante a realcalinização. Apenas os concretos com relação a/c 0,65 com cura de 28 dias não apresentaram a lixiviação da pasta de cobrimento. Os demais corpos-de-prova apresentaram a total solubilização da pasta do concreto na região de cobrimento, deixando os agregados graúdos expostos. Este efeito não foi relatado por outros pesquisadores em trabalhos anteriores, mas, é provável evitá-lo com a diminuição da concentração da solução alcalina para menos de $1 \mathrm{M}$.

Ao final de 47 dias, foi verificada a realcalinização de todo o cobrimento dos corpos-de-prova imersos na solução de hidróxido de potássio através da aspersão do indicador de pH fenolftaleína (Figura 5.17 (b), (d) e (f)). O mesmo procedimento foi adotado para os corpos-de-prova imersos nas soluções de carbonato de sódio e hidróxido de cálcio. Os corpos-de-prova colocados na solução de carbonato de sódio, aos 63 dias de imersão já apresentava o seu cobrimento em contato com a solução alcalina devidamente realcalinizado (Figura 5.17 (a), (d) e (e)). No entanto, os corposde-prova imersos na solução de hidróxido de cálcio, mesmo depois de 63 dias, apresentaram um comportamento muito singular, no qual apenas a região próxima à armadura encontrava-se realcalinizada. Enquanto, o cobrimento do concreto não apresentava qualquer presença da frente de realcalinização (Figura 5.17 (c), (d) e (g)). Este comportamento é característico e esperado somente nas RAE, devido à aplicação de corrente e formação de hidroxilas ao redor da armadura. 
(a)

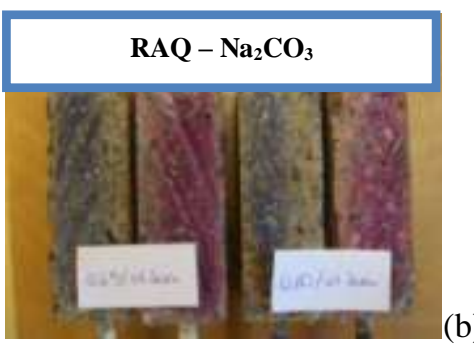

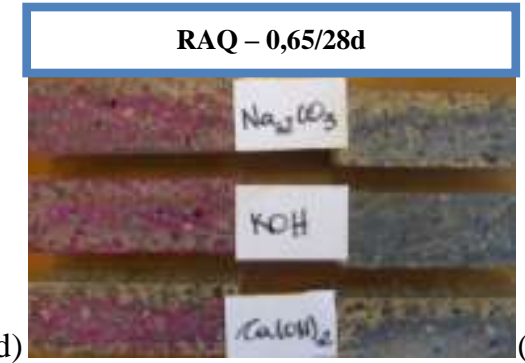
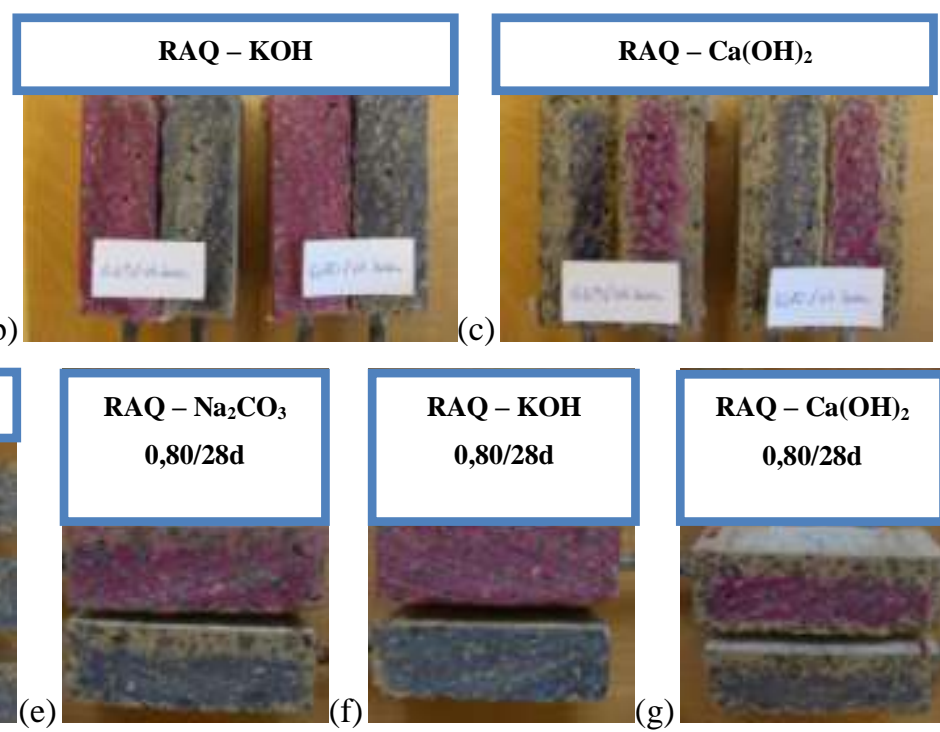
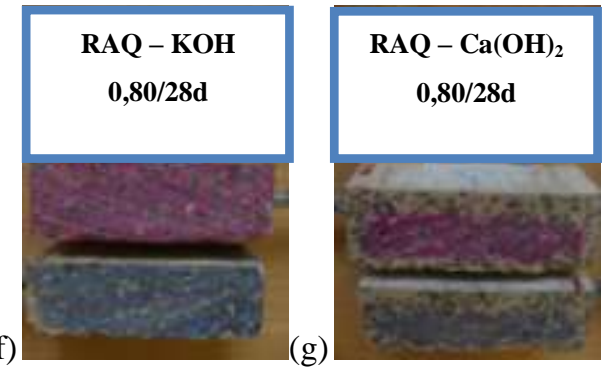

Figura 5.17. Corpos-de-prova realcalinizados sem a aplicação de corrente elétrica: (a) a/c 0,65 (esquerda) e 0,80 (direita) com 1 dia de cura com a solução de $\mathrm{Na}_{2} \mathrm{CO}_{3}$; (b) a/c 0,65 (esquerda) e 0,80 (direita) com 1 dia de cura com a solução de $\mathrm{KOH}$; (c) a/c 0,65 (esquerda) e 0,80 (direita) com 1 dia de cura com a solução de $\mathrm{Ca}(\mathrm{OH})_{2}$; (d) a/c 0,65 com 28 dias de cura com as três soluções estudadas; e a/c 0,80 com 28 dias de cura realcalinizado com (e) solução de $\mathrm{Na}_{2} \mathrm{CO}_{3}$, (f) solução de $\mathrm{KOH}$ e (g) solução de $\mathrm{Ca}(\mathrm{OH})_{2}$.

As primeiras medidas de potencial de corrosão (Figura 5.18) foram realizadas logo após a verificação da realcalinização do cobrimento da armadura (corpos-de-prova ainda saturados). Somente para a solução de hidróxido de cálcio, o tratamento foi finalizado sem a constatação da realcalinização do cobrimento do concreto carbonatado, conforme descrito anteriormente. No entanto, os maiores potenciais de corrosão encontrados foram justamente nestes corpos-de-prova.

As medidas iniciais de potencial na RAQ também se mostraram bastante eletronegativas, porém, não tanto quanto o observado na RAE (Figura 5.8). Os valores muito negativos encontrados na RAE, conforme explicado anteriormente, provavelmente, ocorreram em razão do fato das barras ainda estarem com certo grau de polarização, ou seja, seu valor de potencial ainda estava deslocado pela polarização imposta durante o tratamento. Com o intuito de observar mais claramente os potenciais iniciais de corrosão (ou seja, não saturados), ao final da RAQ, os corpos-de-prova ficaram 24 horas em uma estufa ventilada à $40^{\circ} \mathrm{C}$, e mais 6 dias em caixas com umidade relativa de $75 \%$, para então serem obtidos novos potenciais de corrosão. 


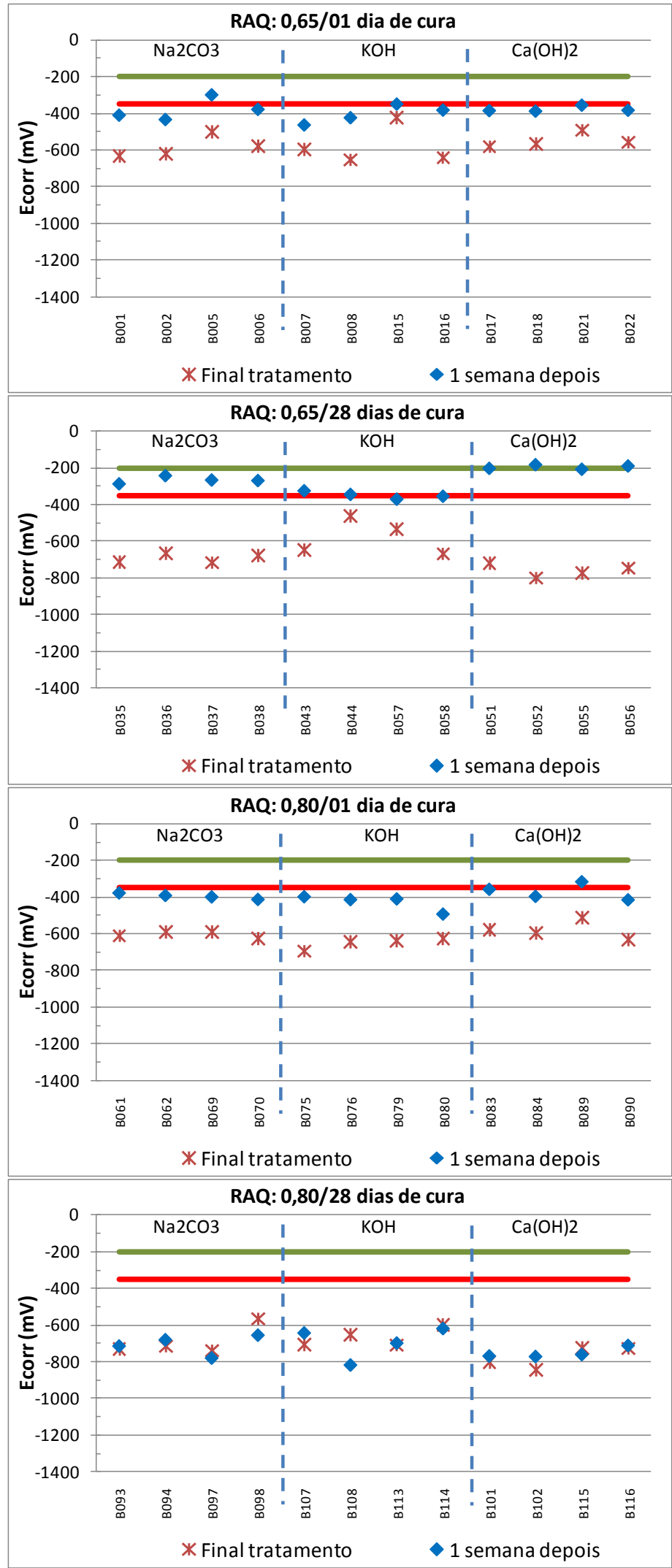

Figura 5.18. Leituras de potencial de corrosão nas barras dos corpos-de-prova realcalinizados quimicamente logo após a finalização do tratamento ainda saturados, e depois de uma semana secos e mantidos em uma caixa com umidade de $75 \pm 5 \%$. 
Na Figura 5.18 foi possível observar o aumento do potencial de corrosão após a sua secagem (uma semana depois de finalizado o tratamento) em relação ao potencial medido imediatamente depois de finalizado o tratamento, porém, observa-se que ainda assim apresentando um potencial bastante eletronegativo. Com exceção do concreto de relação a/c 0,65 com 28 dias de cura. Pois, estes corpos-de-prova depois da secagem do concreto na estufa ventilada já apresentavam uma probabilidade de corrosão de $50 \%$ para os realcalinizados com as soluções de carbonato de sódio, e de 5\% de probabilidade de corrosão nos realcalinizados com hidróxido de cálcio.

As leituras seguintes foram realizadas mensalmente com os corpos-de-prova secos, até o tratamento de realcalinização química completar 6 meses. Assim como na realcalinização eletroquímica, os corpos-de-prova permaneceram em condições de temperatura e umidade iguais às das fases de passivação e carbonatação dos mesmos, $23 \pm 3^{\circ} \mathrm{C}$ e $75 \pm 5 \%$, durante todo o período de verificação da reconstituição da película de passivação. Nos gráficos da Figura 5.19 foi possível observar a evolução do potencial de corrosão com 1, 3 e após 6 meses de finalização da RAQ.

Ao contrário do descrito em estudos realizados anteriormente por Araújo (2004) e Sá (2006), após seis meses, a solução de carbonato de sódio apresentou potenciais de corrosão menos eletronegativos do que os obtidos com a solução de hidróxido de potássio, classificada pelos pesquisadores como a mais eficiente. No entanto, foi a solução de hidróxido de cálcio que proporcionou aos concretos estudados os maiores (ou mais eletropositivos) potenciais de corrosão, chegando à maioria dos casos a valores positivos de potencial de corrosão. Mesmo esta solução não proporcionando a realcalinização do cobrimento do concreto carbonatado, observou-se que solução alcalina de hidróxido de cálcio apresentou a capacidade de realcalinizar justamente o concreto ao redor da armadura, propiciando a repassivação da mesma.

Com seis meses de finalização do tratamento de RAQ, praticamente todas as armaduras apresentavam um potencial de corrosão bastante alto (ou eletropositivo), com probabilidade de corrosão de 5\%. Apenas as barras B007 e B114 ainda se encontravam com um potencial de corrosão bastante baixo (ou eletronegativo), porém, as barras irmãs (B008 e B113) já se encontravam na probabilidade de corrosão de 5\% após 6 meses de finalizado o tratamento. 


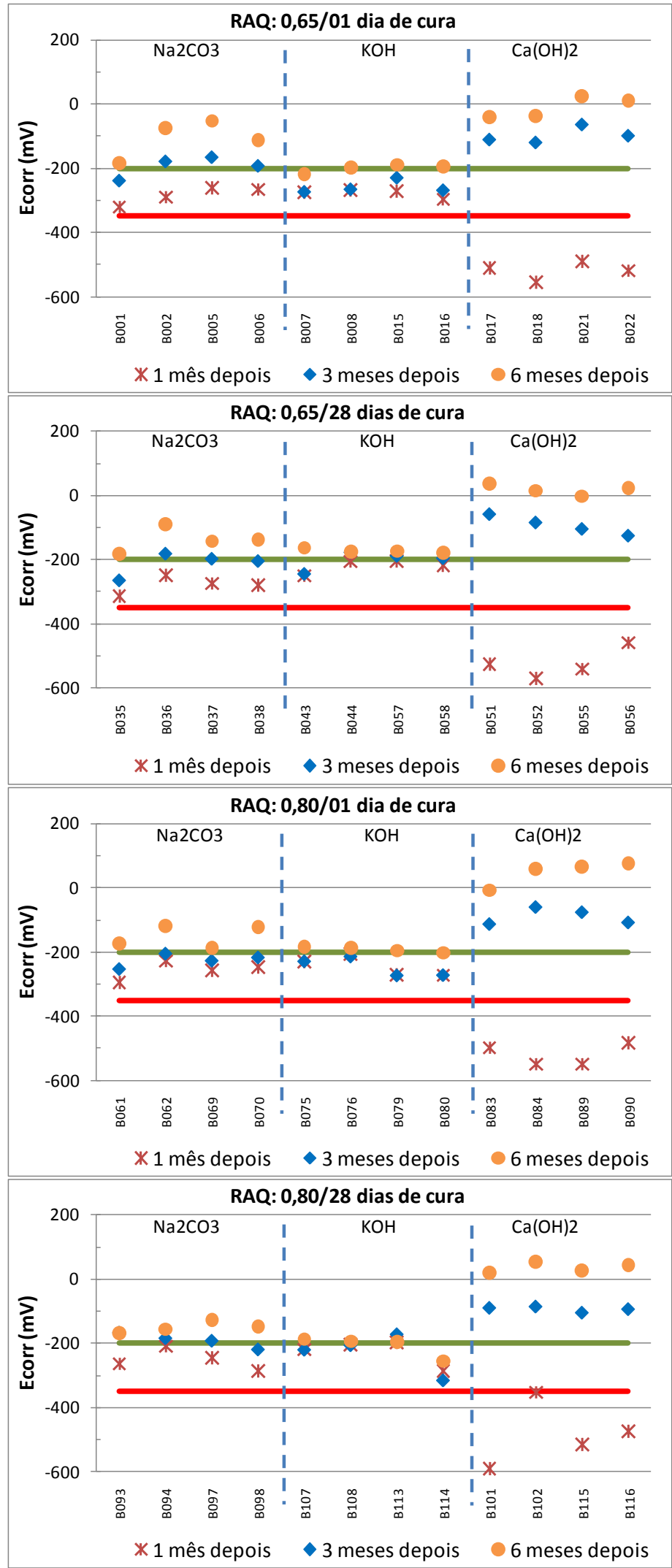

Figura 5.19. Leituras de potencial de corrosão nas barras dos corpos-de-prova realcalinizados quimicamente, após 1, 3 e 6 meses da finalização do tratamento.

Os gráficos da Figura 5.19 indicam também a velocidade de cada solução em propiciar a repassivação da armadura depois de finalizado o tratamento. Em todos os 
concretos estudados, a solução saturada de hidróxido de cálcio foi a que apresentou maior velocidade em repassivar a armadura, elevando o potencial de corrosão a valores bastante eletropositivos. Seguida da solução de hidróxido de cálcio, estão as soluções de carbonato de sódio e de hidróxido de potássio, respectivamente.

As primeiras medidas de EIE nos corpos-de-prova RAQ foram realizadas um mês depois de finalizado o tratamento utilizando as soluções de carbonato de sódio e hidróxido de potássio, e depois de uma semana nos realcalinizados com a solução saturada de hidróxido de cálcio. Assim como observado na realcalinização eletroquímica, mesmo as armaduras estando imersas em concreto realcalinizado (Figura 5.17), algumas barras realcalinizadas com a solução de hidróxido de potássio ainda encontravam-se despassivadas depois de 4 meses de finalização do tratamento, o mesmo não pode ser afirmado para as barras realcalinizadas com a solução de carbonato de sódio.

É possível observar nos gráficos da Figura 5.21(a) à Figura 5.24(a) uma inclinação mais acentuada do último arco de Nyquist aos quatro meses, quando comparado com os gráficos do primeiro mês após a finalização do tratamento. Ou seja, mesmo algumas barras ainda apresentando um comportamento típico da despassivação, as mesmas demonstram que a corrente está tendo uma maior dificuldade em atravessar a barra, devido ao processo de reconstituição da película de passivação. Já os diagramas de Bode não apresentam um aumento significativo da sua inclinação do ângulo de fase na freqüência de $0,01 \mathrm{~Hz}$ (da Figura 5.21(b) à Figura 5.24(b)), como foi possível observar nos gráficos referentes à RAE depois de um ano de finalização do tratamento. Porém, isto ocorre em razão da maior necessidade de tempo para a formação completa da película de repassivação. O mesmo ocorre para a constância da inclinação da curva no eixo $|\mathrm{Z}|$ (da Figura 5.21(c) à Figura 5.24(c)).

Exceção somente em relação aos resultados referentes à realcalinização realizada com a solução de hidróxido de potássio. Pois, neste caso as variações de inclinação da curva de Nyquist, e dos diagramas de Bode são características de uma barra em processo passivo de corrosão.

Outro efeito passível de ser encontrado durante a realização dos ensaios de EIE é o deslocamento do semicírculo $(\alpha)$, na região de alta ou de baixa frequiência, abaixo do eixo de impedância real (Figura 5.20). De acordo com Machado (2004), este comportamento nos diagramas de Nyquist pode ser devido a uma superfície não homogênea do eletrodo ou ainda, a um grau de não idealidade do comportamento 
capacitivo. Ainda de acordo com a pesquisadora, o parâmetro $\alpha$ pode ser tomado como dispersões relacionadas com a não homogeneidade do concreto próximo à armadura, correspondendo aos produtos formados nos poros do cimento (região de freqüência alta); ou dispersões relacionadas com a localização do produto de corrosão na superfície do metal (região de freqüência baixa).

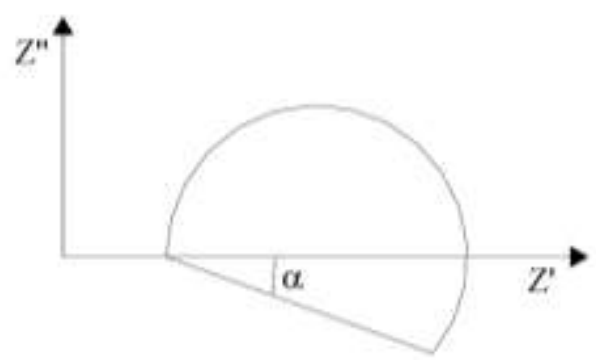

Figura 5.20. Deslocamento do semicírculo $(\alpha)$ abaixo do eixo de impedância real (Silva, 2006).

Na ampliação do diagrama de Nyquist da Figura 5.22(a) é possível observar justamente este comportamento, principalmente quando realizado o ensaio nos corposde-prova realcalinizados com a solução saturada de hidróxido de cálcio. E mesmo assim, somente no período de uma semana depois de finalizado o tratamento. Como este deslocamento se encontrava na região de baixa freqüência, e os gráficos de Bode mostravam um baixo ângulo de frequiência e um baixo módulo de impedância (Figura 5.22(b) e Figura 5.22(c)), pode ser caracterizado que esteja ocorrendo a formação de algum produto ainda corrosivo sobre a barra. Aos quatro meses, a barra já não apresentava mais este comportamento e sim um deslocamento horizontal em relação ao eixo de impedância real. E os gráficos de Bode ilustram um aumento significativo dos valores de ângulo de freqüência e de módulo de impedância.

Em relação aos deslocamentos horizontais no eixo de impedância real encontrado nos diagramas de Nyquist da Figura 5.21 à Figura 5.24 referente à RAQ, e também na RAE ilustrada na Figura 5.11 e na Figura 5.13, estes ocorreram somente quando a solução alcalina utilizada foi a solução saturada de hidróxido de cálcio. Como esta solução alcalina teve a particulariade de conseguir repassivar a armadura, sem conseguir realcalinizar o concreto de cobrimento, provavelmente este deslocamento horizontal deve ser proveniente a algum produto de realcalnização formado ao redor da armadura. Não foi encontrada qualquer referência a este efeito nos periódicos, teses e livros consultados. Neste caso seria necessário realizar um estudos de microscopia posteriormente para avaliação do que poderia ter realizado tal efeito. 


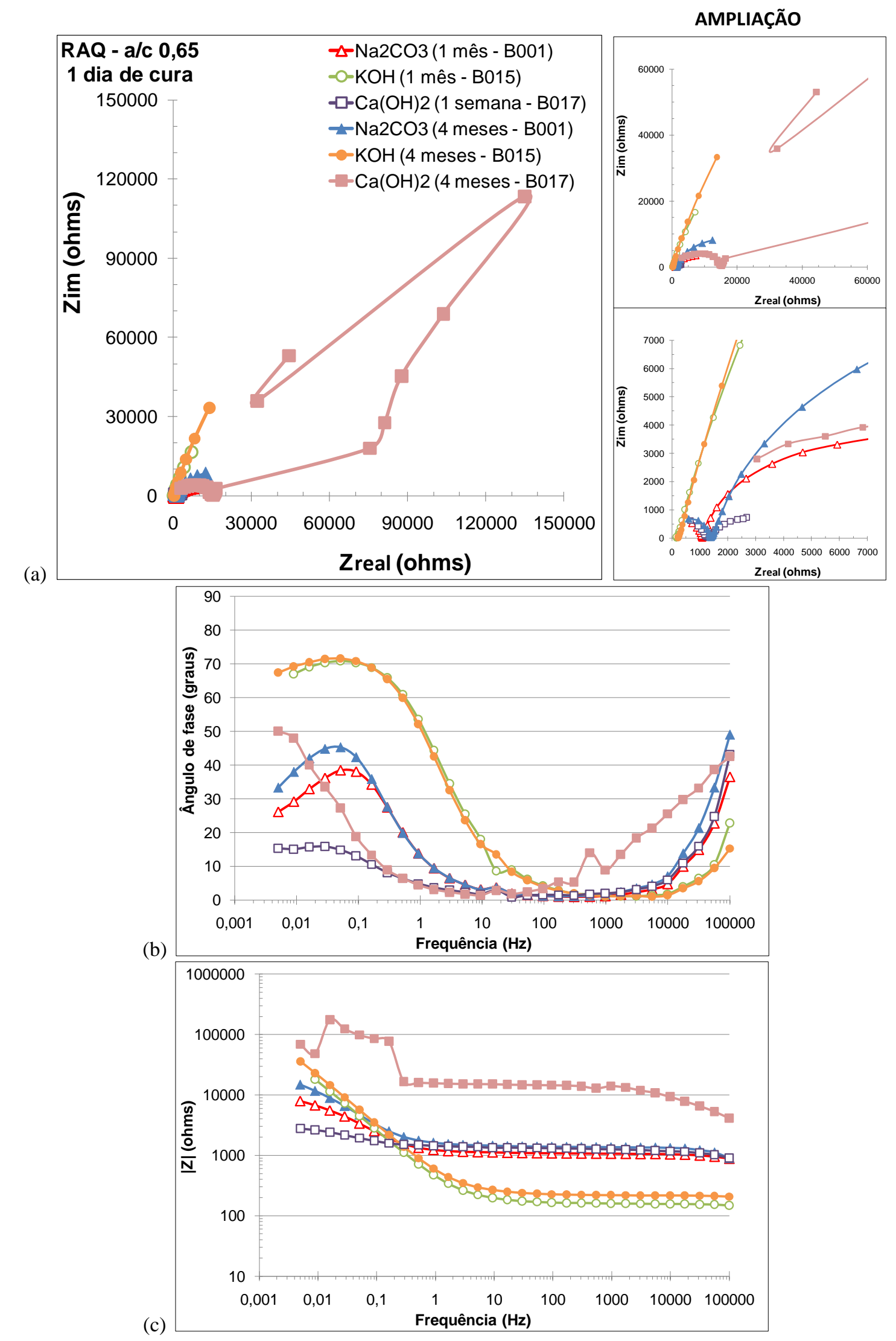

Figura 5.21. Evolução dos espectros de impedância obtidos nos concretos de relação a/c 0,65 e tempo de cura de 1 dia, com uma semana e também com 4 meses depois de finalizado o tratamento de RAQ, com o número da barra a que se referem (Bxxx): (a) Diagrama de Nyquist, (b) e (c) Diagramas de Bode. 


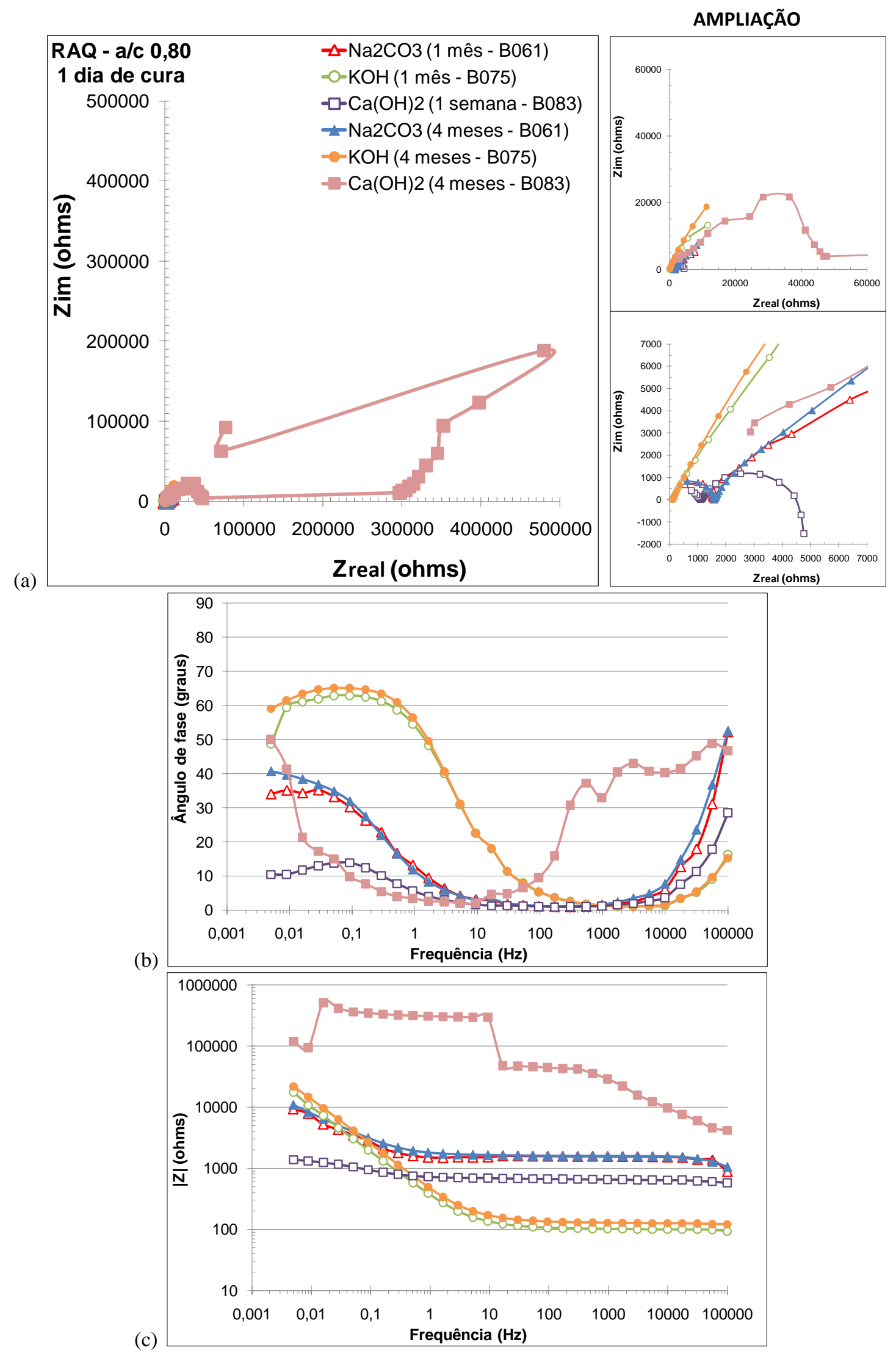

Figura 5.22. Evolução dos espectros de impedância obtidos nos concretos de relação a/c 0,80 e tempo de cura de 1 dia, com uma semana e também com 4 meses depois de finalizado o tratamento de RAQ, com o número da barra a que se referem (Bxxx): (a) Diagrama de Nyquist, (b) e (c) Diagramas de Bode. 


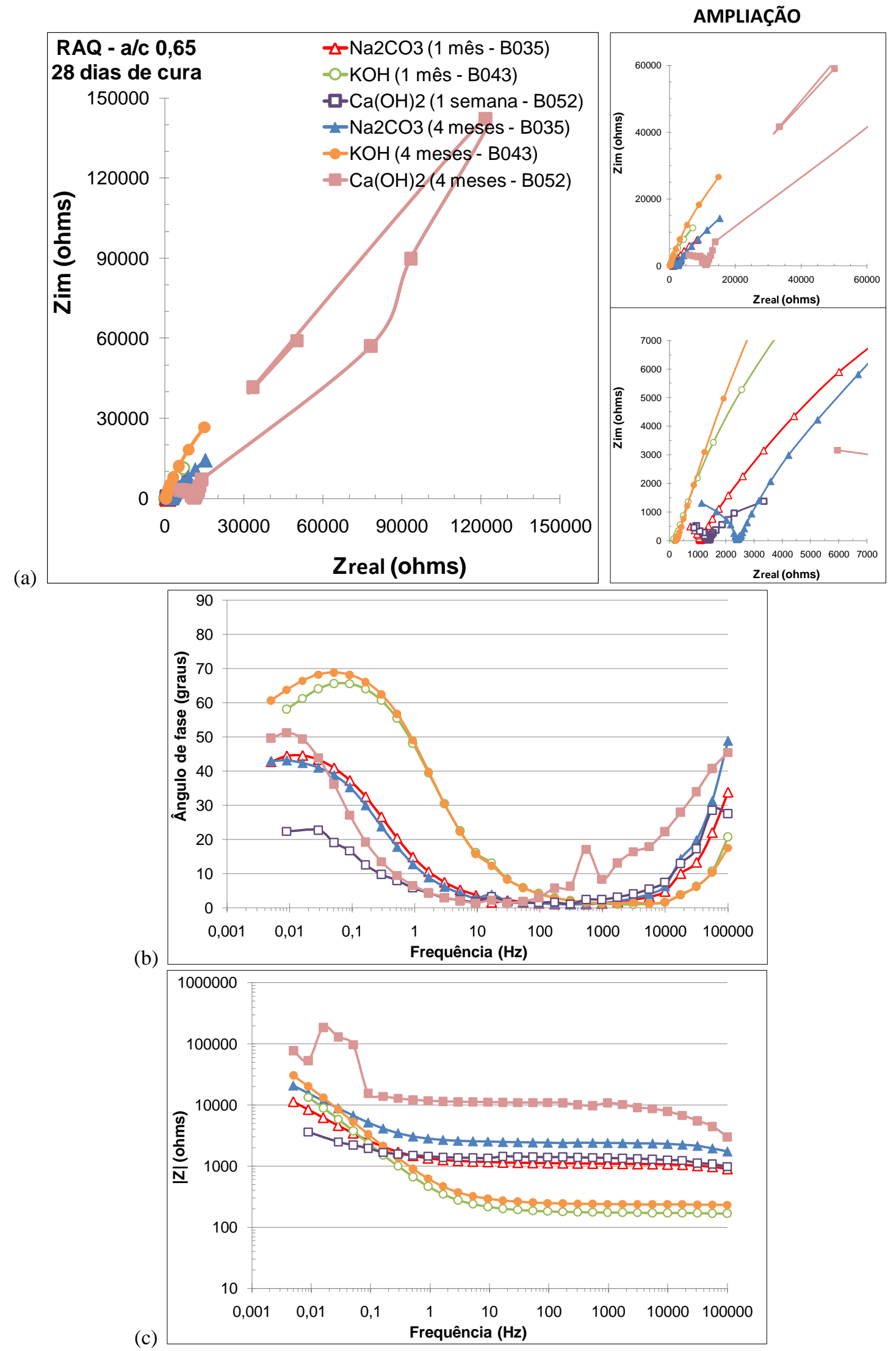

Figura 5.23. Evolução dos espectros de impedância obtidos nos concretos de relação a/c 0,65 e tempo de cura de 28 dias, com uma semana e também com 4 meses depois de finalizado o tratamento de RAQ, com o número da barra a que se referem (Bxxx): (a) Diagrama de Nyquist, (b) e (c) Diagramas de Bode. 


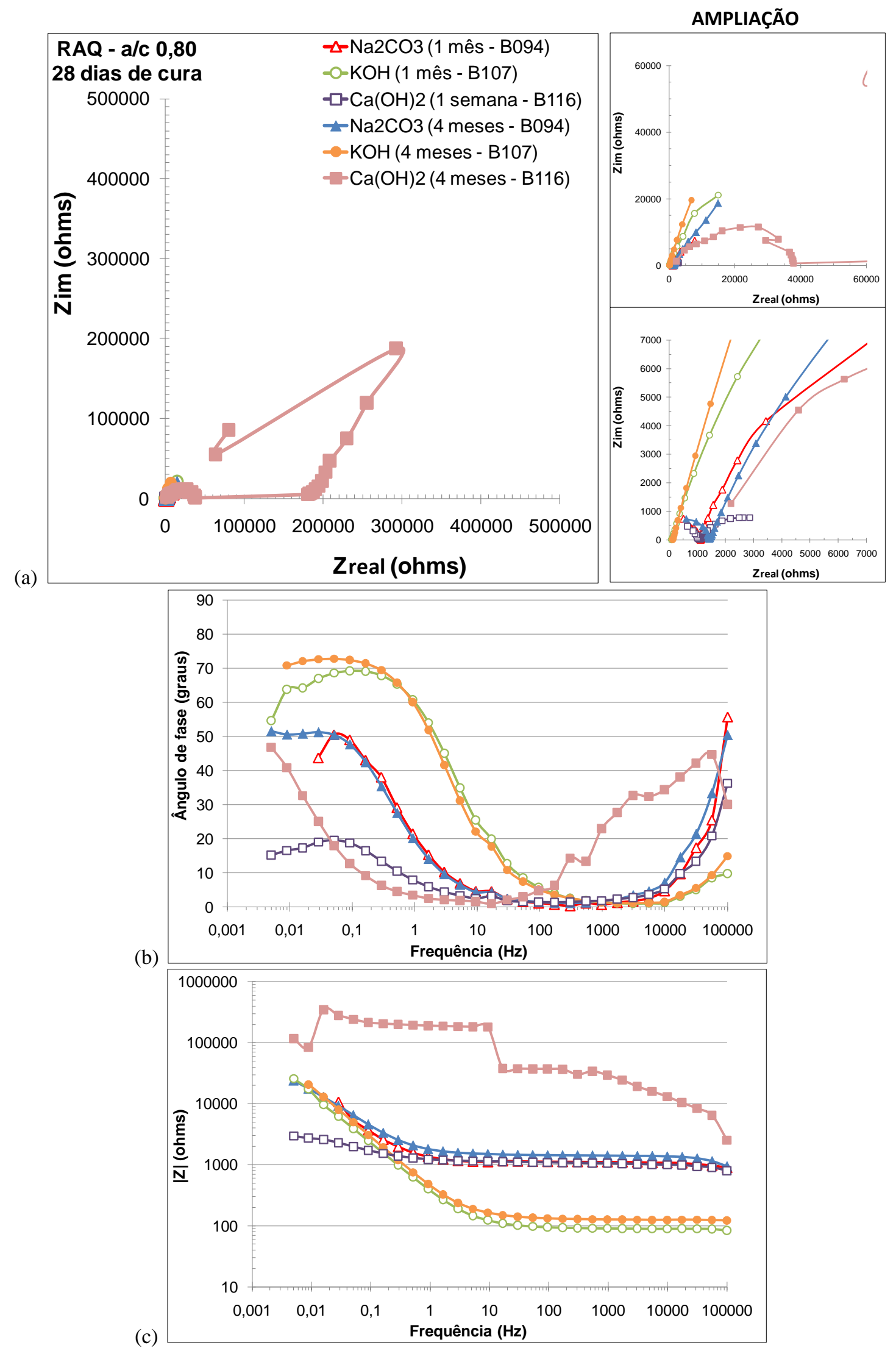

Figura 5.24. Evolução dos espectros de impedância obtidos nos concretos de relação a/c 0,80 e tempo de cura de 28 dias, com uma semana e também com 4 meses depois de finalizado o tratamento de RAQ, com o número da barra a que se referem $(\mathrm{Bxxx})$ : (a) Diagrama de Nyquist, (b) e (c) Diagramas de Bode. 


\subsubsection{EFICÁCIA DAS REALCALINIZAÇÕES NA REPASSIVAÇÃO DAS} ARMADURAS

No item anterior foram abordados os resultados das realcalinizações eletroquímicas e químicas em relação à repassivação das armaduras. No entanto, achouse necessário e coerente realizar uma análise comparativa, entre o estado das armaduras antes da carbonatação (estado passivo de corrosão) e a sua reconstituição após a finalização dos tratamentos de realcalinização, eletroquímica (da Figura 5.28 à Figura 5.31) e química (da Figura 5.34 à Figura 5.37).

Nos diagramas de Nyquist apresentados nesta pesquisa, sempre se observa a formacão de dois arcos capactivos incompletos em regiões distintas de frequiência, região de alta frequiência, maior que $10^{4} \mathrm{~Hz}$, e de baixa frequiência, menor que $10 \mathrm{~Hz}$. Em alguns trabalhos, como Lemoine et al. (1990, citado por Machado, 2004), Gu et al. (1997) e Silva (2006), verificou-se a formação de um semicírculo intermediário na freqüência entre $10^{4} \mathrm{~Hz}$ e $10 \mathrm{~Hz}$ (região de média freqüência). Segundo os autores, este semicírculo está relacionado à formação de novos produtos na superfície da armadura, podendo ser de corrosão, ou precipitados de hidróxido de cálcio $(\mathrm{CH})$ ou de silicato de cálcio hidratado (C-S-H), dependendo da evolução da hidratação do concreto.

De acordo com Silva (2006), para comprovar se o arco intermediário formado é um produto de corrosão ou uma camada de $\mathrm{CH}$ ou C-S-H depositado na superfície da armadura, é necessário avaliar o arco obtido na região de baixa freqüência. Isto porque este semicírculo intermediário pode ser formado tanto em barras passivas como ativas, dependendo se o arco seguinte formado é característico de uma corrosão ativa ou passiva. No entanto, o aparecimento ou não deste arco intermediário está relacionado ao estágio no qual a corrosão se encontra: iniciação ou propagação, conforme ilustra a Figura 5.25.

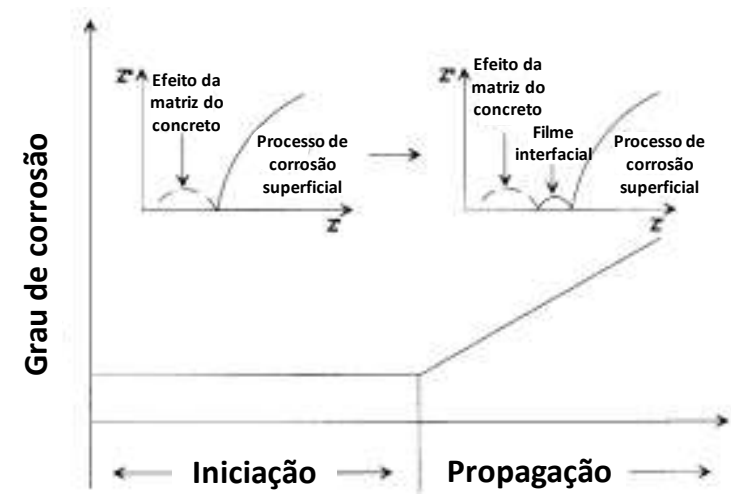

Figura 5.25. Correspondência entre o diagrama de Nyquist e o estágio da corrosão no qual a barra se encontra (adaptada de Gu et al., 1997). 
Porém, os diagramas de Nyquist obtidos neste trabalho não apresentaram a formação deste arco capacitivo na região de média frequiência. Desta maneira, a seguir é realizada separadamente a analise dos parâmetros da EIE somente nas regiões de alta e baixa freqüência dos diagramas de Nyquist e Bode.

As cuvas de impedância que sofreram deslocamentos horizontais no eixo de impedância real nos diagramas de Nyquist: da Figura 5.28 à Figura 5.31 (RAE) e da Figura 5.34 à Figura 5.37 (RAQ), foram sobrepostas por outra curva (nomeada: Curva $\mathrm{Ca}(\mathrm{OH})_{2}$ alterada), cujos pontos deslocados horizontalmente foram excluídos de forma a possibilitar a visualização mais limpa da ascendência das curvas.

\section{a) REALCALINIZACÃO ELETROQUÍMICA (RAE)}

A análise do comportamento através do potencial de corrosão das barras antes e depois do tratamento pode ser observada nos gráficos da Figura 5.26. Nestes gráficos é possível ressaltar os potenciais de corrosão obtidos antes da carbonatação acelerada nos corpos-de-prova secos, e depois de 1 ano de realizado o tratamento eletroquímico, com os corpos-de-prova também secos. Nas duas situações os corpos-deprova ficaram mantidos a uma temperatura de $23 \pm 3^{\circ} \mathrm{C}$ e umidade relativa de $75 \pm 5 \%$.

É possível observar em várias situações, a proximidade dos valores antes da carbonatação e depois de 1 ano de finalizado o tratamento.

Embora nem todas as barras tenham conseguido voltar ao potencial de $5 \%$ de probabilidade de corrosão, pode-se afirmar que a RAE foi eficaz na reconstituição da película de passivação. Em cada solução alcalina utilizada pelo menos uma barra conseguiu ter o potencial de corrosão maior ou igual a $-200 \mathrm{mV}$. Com exceção da solução de hidróxido de potássio no concreto de relação a/c 0,80 com 28 dias de cura, na qual nenhuma das barras conseguiu chegar ao valor de potencial de corrosão de antes da carbonatação, tampouco acima da faixa de $-200 \mathrm{mV}$.

De acordo com Miranda et al. (2003), o grau de corrosão das barras vai influenciar diretamente na eficácia da repassivação através da RAE. Desta maneira, é possível relacionar o grau de corrosão discutido por Miranda et al. (2003), à velocidade de corrosão nas barras devido à carbonatação. Assim, quanto menor o valor da resistência de polarização das barras (Rp), maior será a velocidade de corrosão (icorr), e maiores vão ser as dificuldades das barras para se repassivar. Na Figura 5.27 é possível observar a relação inversa entre o valor de Rp das barras obtido na despassivação das 
armaduras e os potenciais obtidos depois de 12 meses de finalizado o tratamento de RAE.

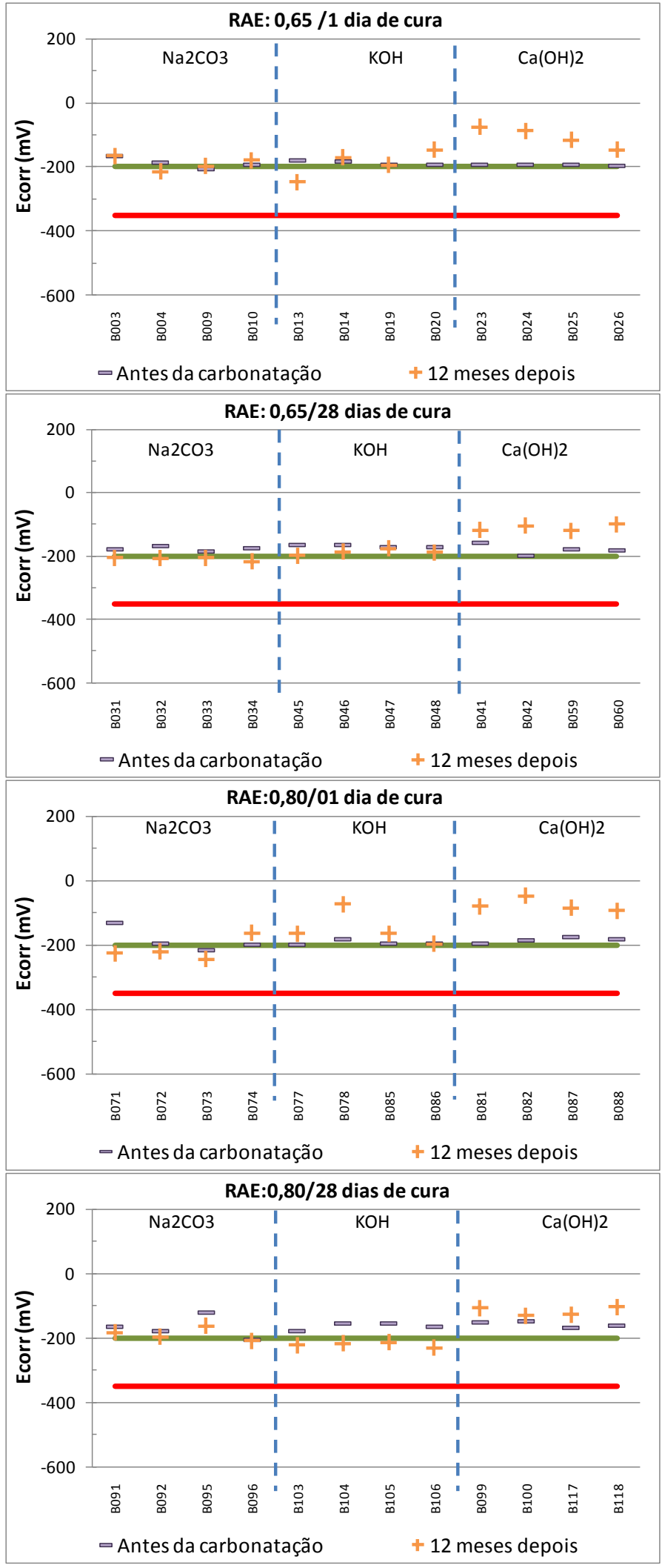

Figura 5.26. Leituras de potencial de corrosão nas barras dos corpos-de-prova antes da realização da carbonatação acelerada e após 12 meses da finalização do tratamento de RAE. 


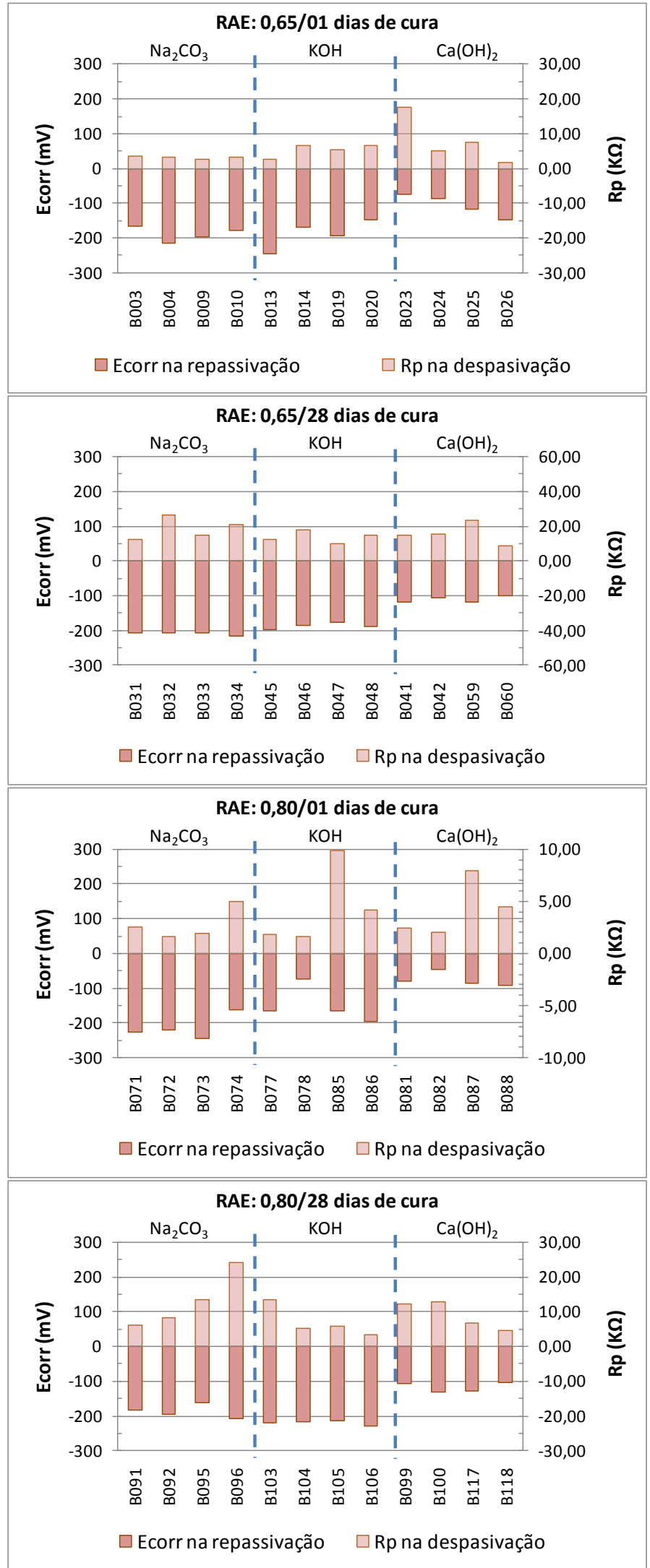

Figura 5.27. Leituras de potencial de corrosão (Ecorr) nas barras dos corpos-de-prova após 12 meses da finalização do tratamento de RAE (período de repassivação), e os valores de resistência de polarização $(\mathrm{Rp})$ estimados pela EIE depois de finalizada a carbonatação (período de despassivação). 


\section{a.1) ANÁLISE DOS PARÂMETROS RELACIONADOS AO CONCRETO - REGIÃO DE ALTA FREQÜENCCIA (MAIOR DE $10^{4} \mathrm{HZ}$ ) NA EIE}

A região de alta freqüência, conforme relatado anteriormente, diz respeito à região de cobrimento do concreto, ou seja, as mudanças ocorridas em relação aos produtos formados no concreto devido à hidratação do cimento ou à combinação dos produtos internos do concreto com os produtos oriundos do ingresso de agentes externos.

Na ampliação da Figura 5.28(a) à Figura 5.31(a) é possível observar que a solução saturada de hidróxido de cálcio utilizada no tratamento proporciona um aumento da resistência ôhmica do concreto (deslocamento para valores maiores de impedância real), quando comparado com os valores obtidos nos corpos-de-prova antes da carbonatação acelerada. Este aumento deve ter sido ocasionado pelos produtos formados com a introdução do hidróxido de cálcio no interior dos mesmos.

Ainda em relação à solução saturada de hidróxido de cálcio utilizada no tratamento, a evolução da resistência ôhmica do concreto pode ser verificada também nos diagramas de Bode (da Figura 5.28(c) à Figura 5.31(c)) através do $|\mathrm{Z}|$ pela freqüência. Observa-se um deslocamento para valores de $|\mathrm{Z}|$ maiores com o aumento da freqüência.

Com exceção do concreto com relação a/c 0,80 e com 1 dia de cura, os demais concretos tratados com as soluções de carbonato de sódio e hidróxido de potássio apresentaram um comportamento bastante semelhante ao encontrado nos concretos antes da carbonatação. O concreto de a/c 0,80 e cura de 1 dia, a solução de hidróxido de potássio proporcionou uma diminuição da resistência ôhmica do concreto (ampliação da Figura 5.29(a) e Figura 5.29(c)). Provavelmente por este concreto ser bastante poroso, a realcalinização com a solução de hidróxido de potássio não favoreceu a formação de compostos que propiciassem a colmatação dos poros, e sim a dissolução dos compostos hidratados presentes. 
$\underline{E I E}$

A região de baixa freqüência caracteriza o estado da armadura, seja o processo de corrosão na sua superfície ou a formação da película de passivação. $O$ comportamento das barras imersas no concreto tratado nos diagramas de Nyquist (da Figura 5.28(a) à Figura 5.31(a)) é claro em relação ao estado passivo no qual as barras se encontram após o tratamento. Onde, a amplitude da reta em relação ao eixo da impedância imaginária é bem menor quando comparado com a reta formada pelos concretos não carbonatados. No entanto, os valores ainda sim continuam bastante altos se compararmos com os valores obtidos na fase de despassivação das armaduras (Figura 5.5(c)), com Zim máximo de 3.000 ohms.

O comportamento passivo das barras também pode ser constatado observando o diagrama de Bode dado por $|\mathrm{Z}|$ em função da freqüência (da Figura 5.28(c) à Figura 5.31(c)), no qual as diferentes curvas obtidas antes e depois do tratamento mostram uma mesma inclinação de $|Z|$. Em relação ao diagrama de Bode dado pelo ângulo de fase em função da freqüência, os ângulos de fase obtidos nas curvas das soluções utilizadas no tratamento foram bem próximos ao ângulo de fase obtido na curva de antes da carbonatação (da Figura 5.28(b) à Figura 5.31(b)), entre 70 e $80^{\circ}$. Apenas a solução saturada de hidróxido de cálcio, e nos concretos de relação a/c 0,65 (Figura 5.38(b) e Figura 5.40(b)), apresentaram um ângulo de fase mais baixo do que os demais, de aproximadamente $60^{\circ}$. No entanto, ainda sim, bem acima dos $25^{\circ}$ apresentado durante a fase de despassivação das armaduras (Figura 5.5(b)). 

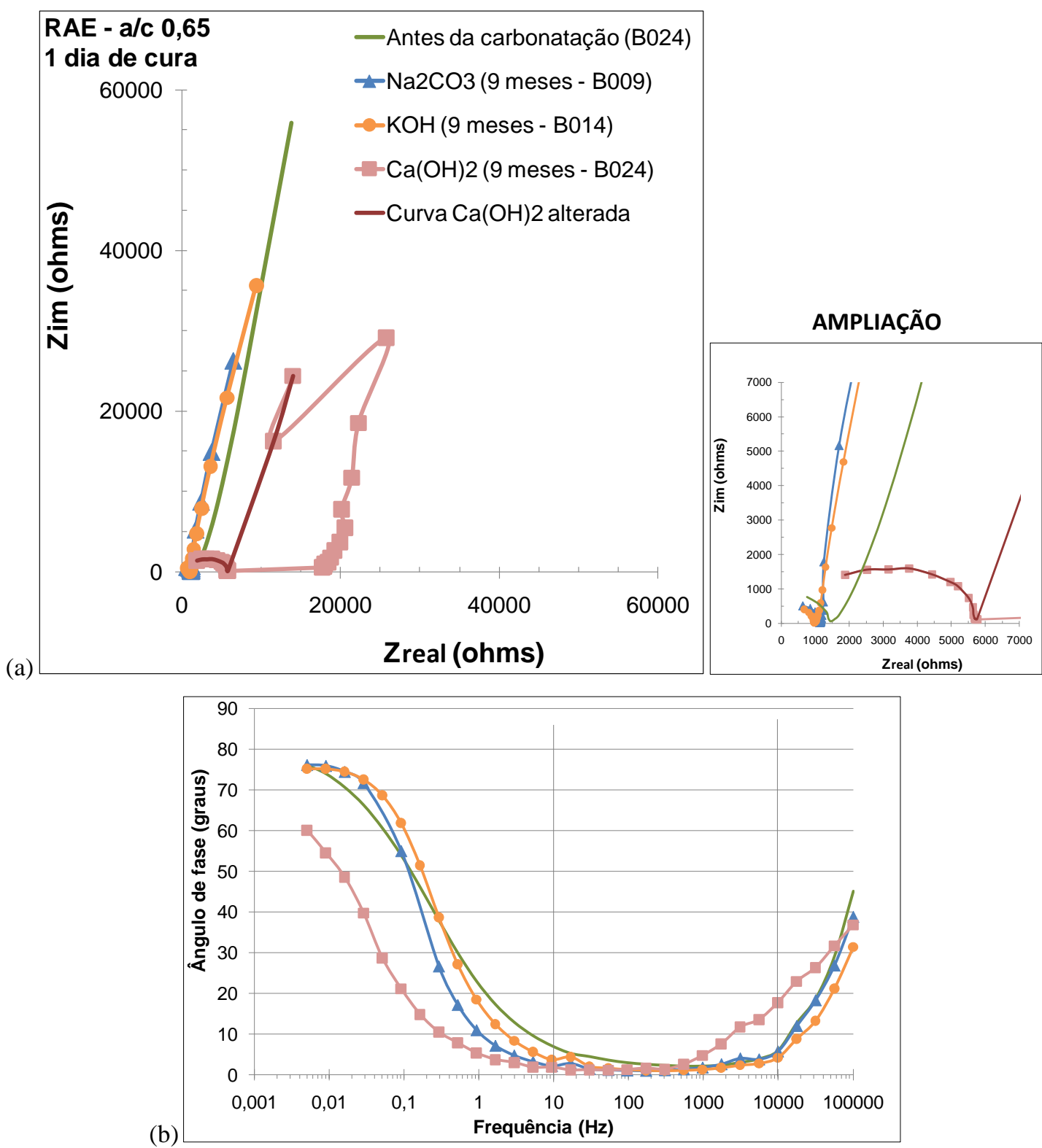

(b)

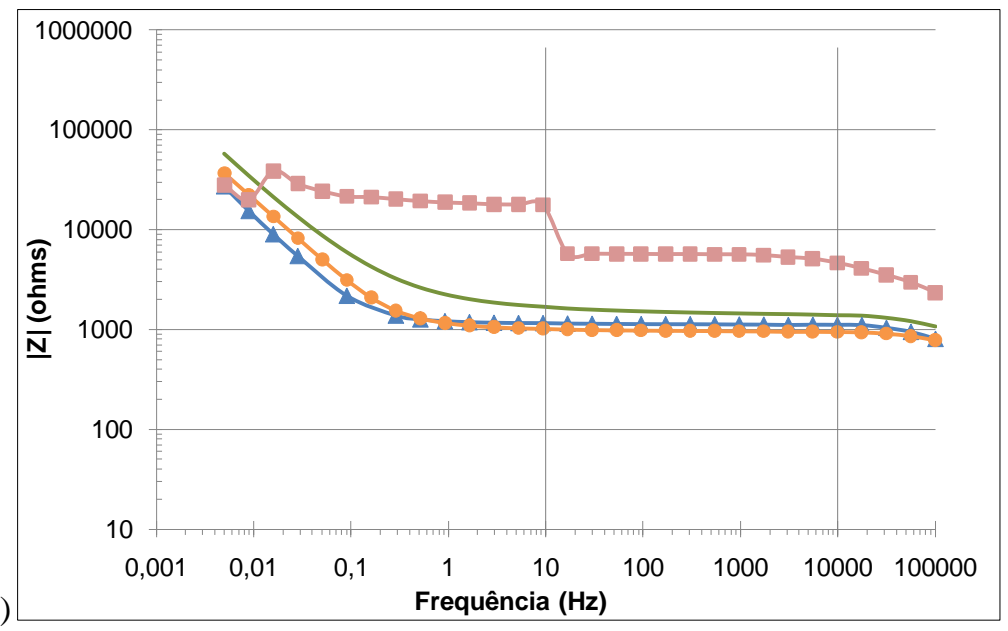

Figura 5.28. Evolução dos espectros de impedância obtidos nos concretos de relação a/c 0,65 e tempo de cura de 1 dia, antes de iniciada a carbonatação, e depois de 9 meses de finalizado o tratamento de RAE, com o número da barra a que se referem $(\mathrm{Bxxx})$ : (a) Diagrama de Nyquist, (b) e (c) Diagramas de Bode. 


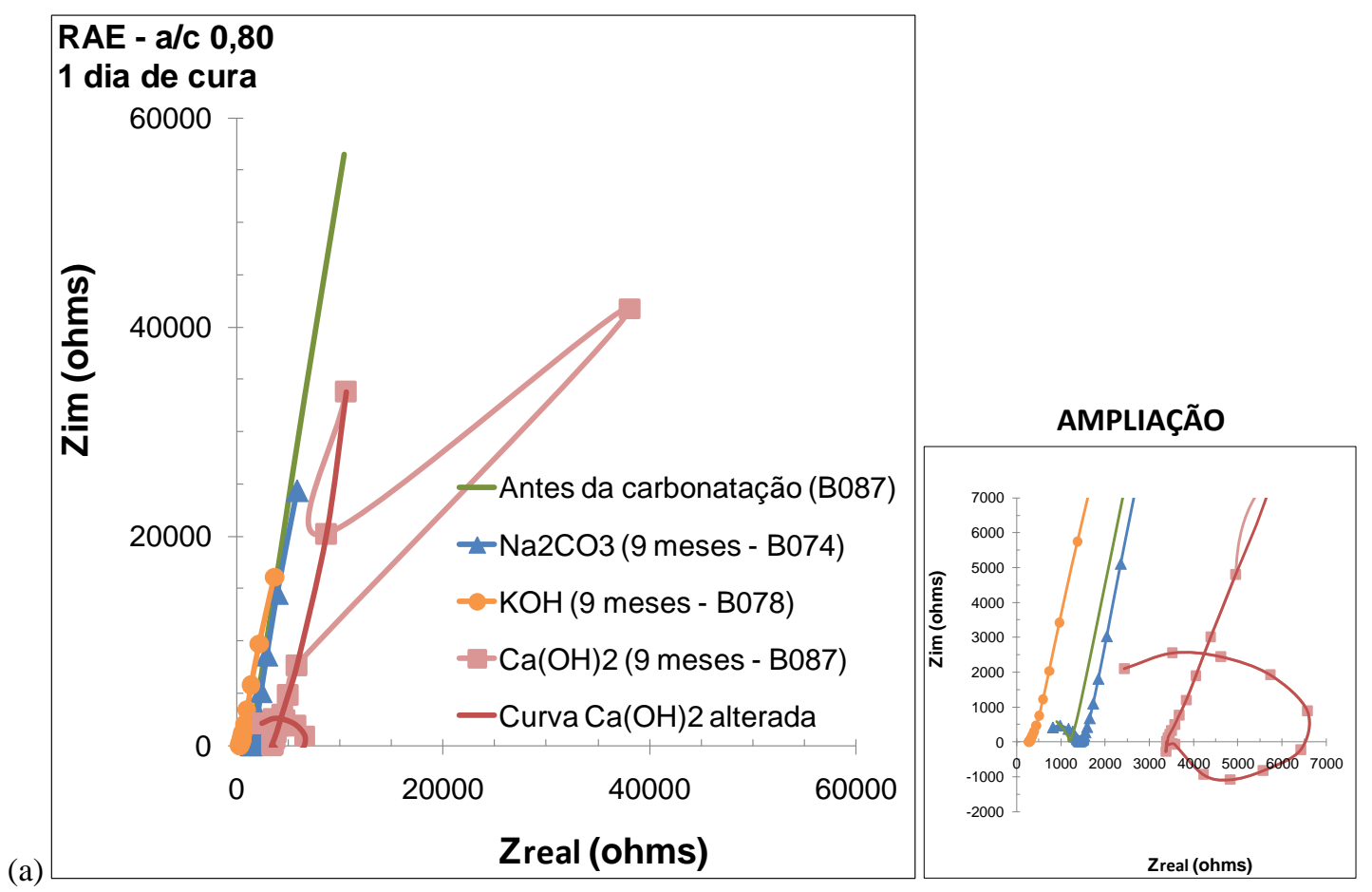

(a)

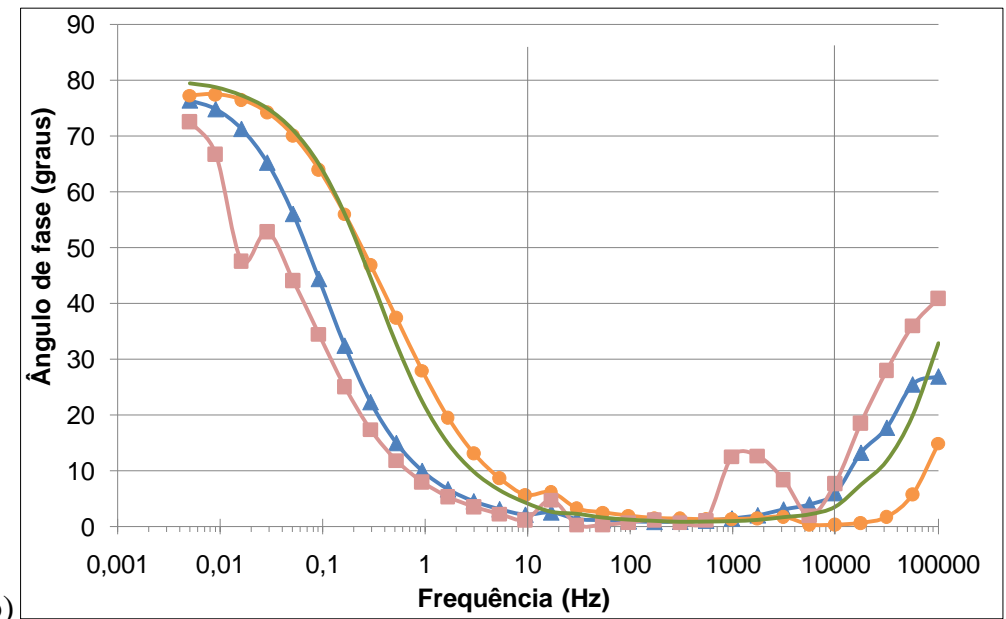

(b)

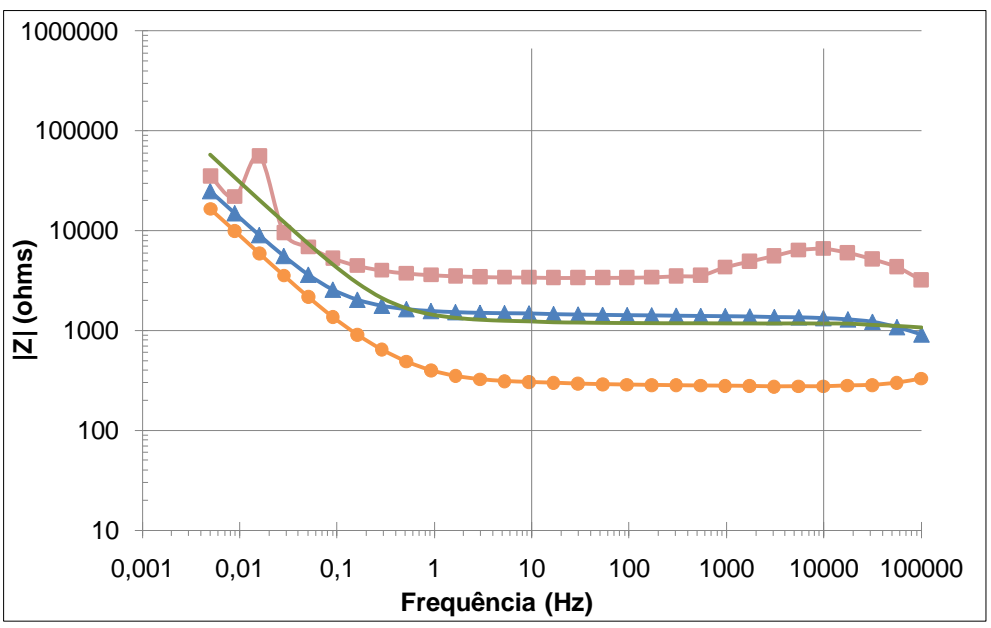

Figura 5.29. Evolução dos espectros de impedância obtidos nos concretos de relação a/c 0,80 e tempo de cura de 1 dia, antes de iniciada a carbonatação, e depois de 9 meses de finalizado o tratamento de RAE, com o número da barra a que se referem $(\mathrm{Bxxx})$ : (a) Diagrama de Nyquist, (b) e (c) Diagramas de Bode 

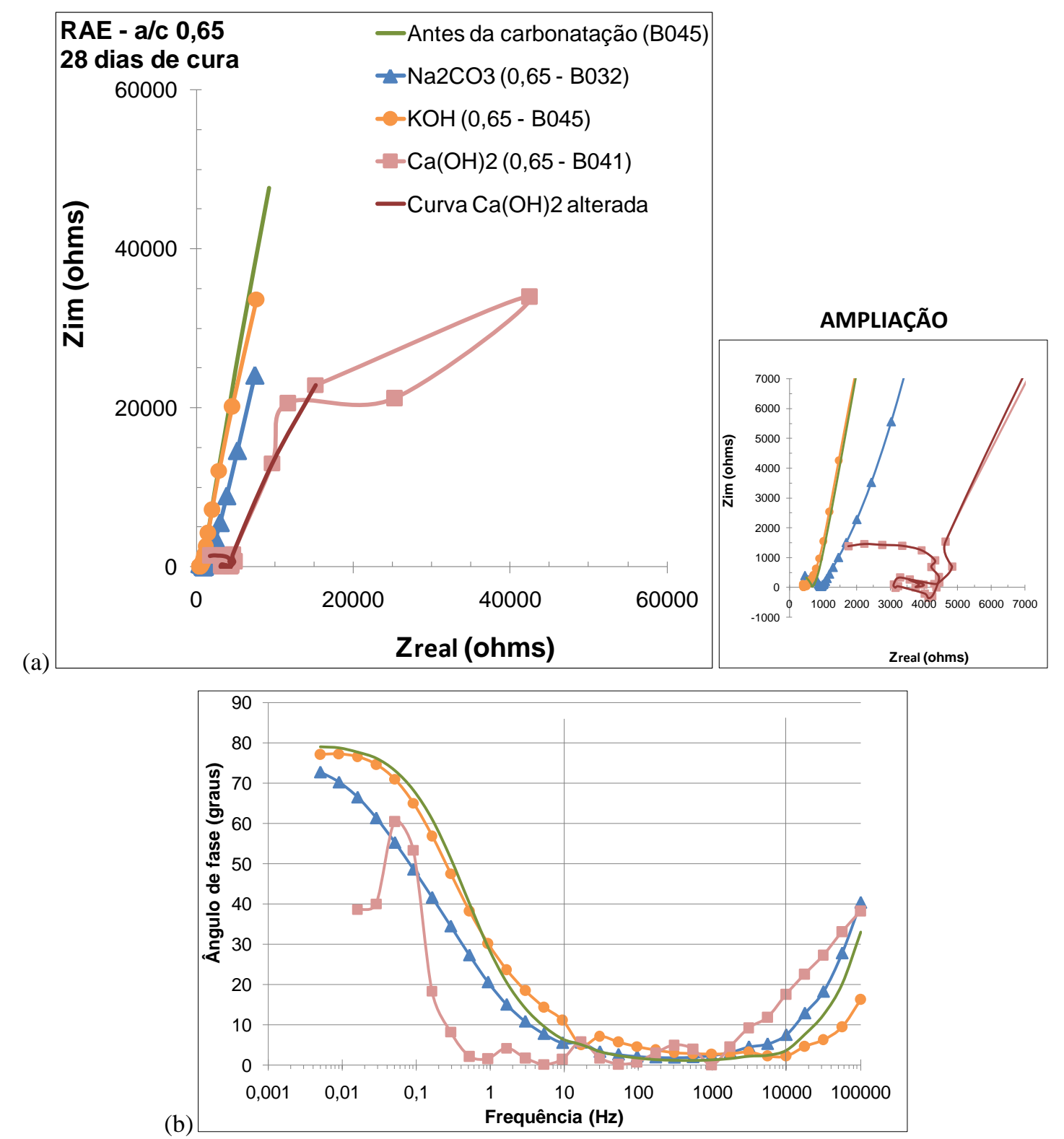

(b)

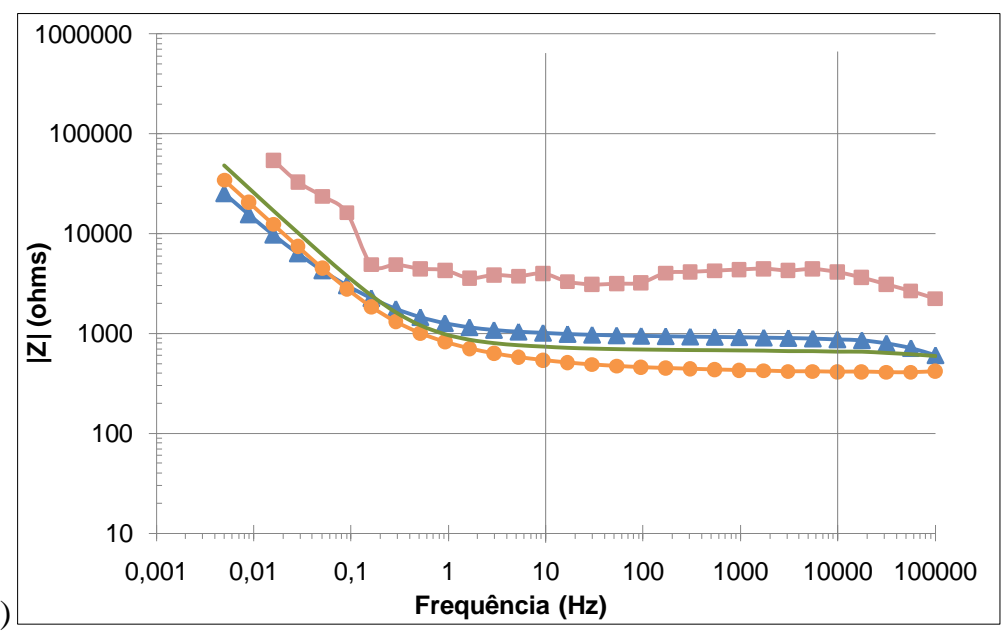

Figura 5.30. Evolução dos espectros de impedância obtidos nos concretos de relação a/c 0,65 e tempo de cura de 28 dias, antes de iniciada a carbonatação, e depois de 9 meses de finalizado o tratamento de RAE, com o número da barra a que se referem $(\mathrm{Bxxx})$ : (a) Diagrama de Nyquist, (b) e (c) Diagramas de Bode. 


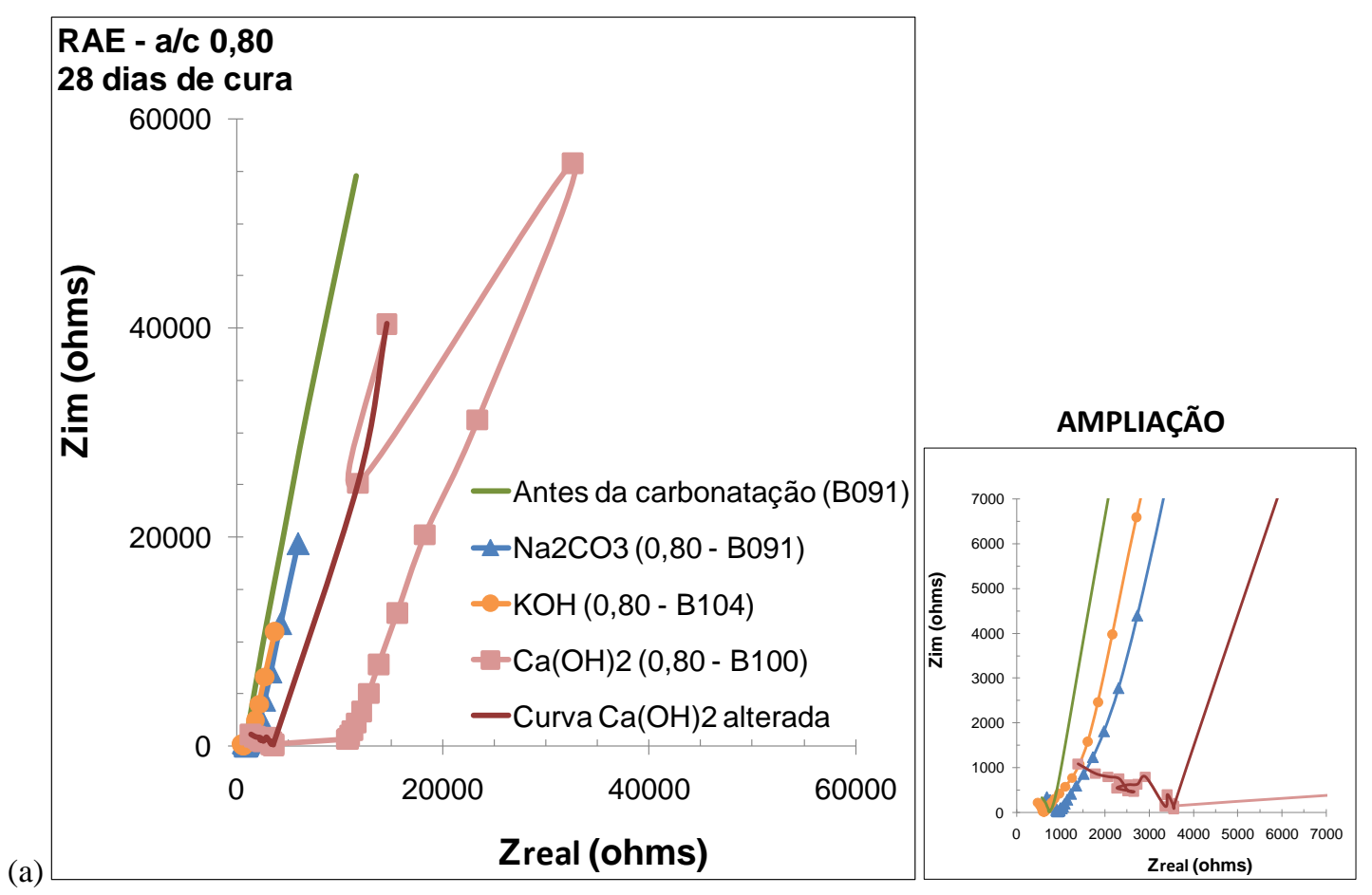

(a)

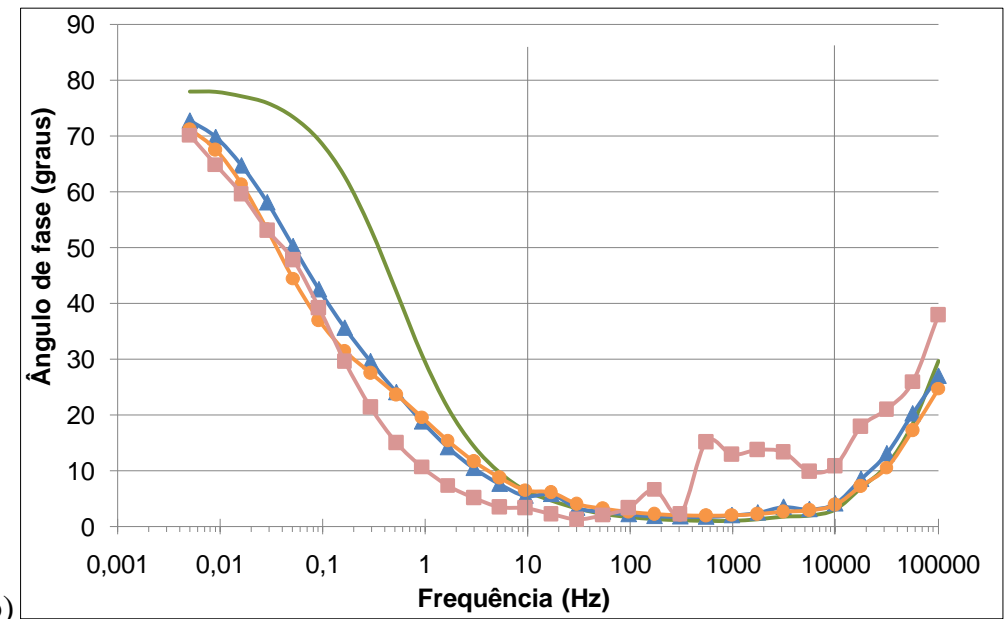

(b)

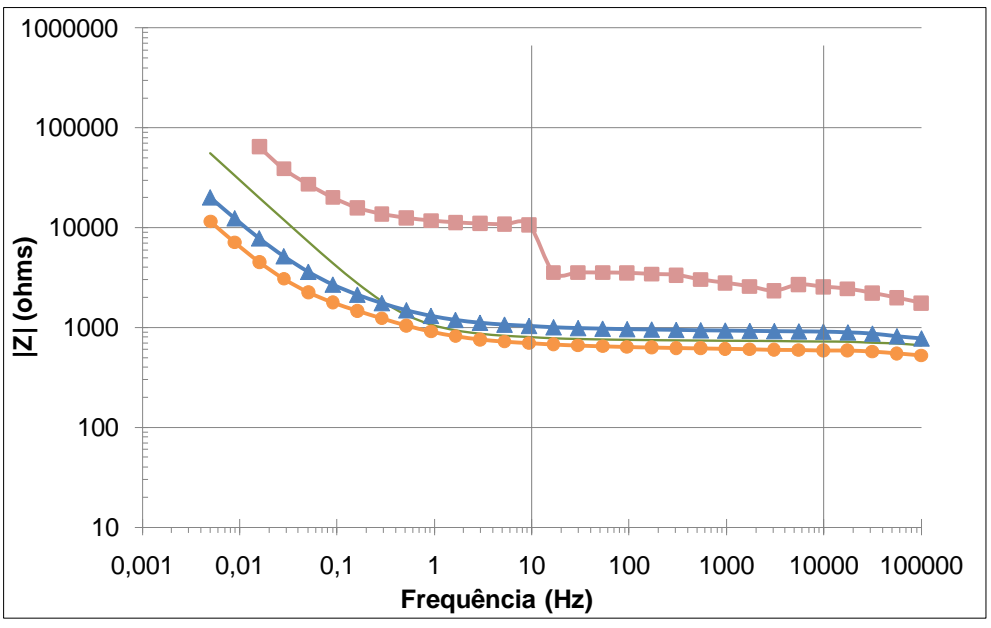

Figura 5.31. Evolução dos espectros de impedância obtidos nos concretos de relação a/c 0,80 e tempo de cura de 28 dias, antes de iniciada a carbonatação, e depois de 9 meses de finalizado o tratamento de RAE, com o número da barra a que se referem $(\mathrm{Bxxx})$ : (a) Diagrama de Nyquist, (b) e (c) Diagramas de Bode. 


\section{b) REALCALINIZACẼO QUÍMICA $(R A Q)$}

Ao contrário do observado na RAE (Figura 5.26), a realcalinização química só apresentou duas barras com potencial de corrosão abaixo da faixa de $-200 \mathrm{mV}$ depois de 6 meses de finalizado o tratamento (Figura 5.32). As duas situações foram com as barras realcalinizadas com a solução de hidróxido de potássio: uma imersa no concreto de relação a/c 0,65 com cura de 01 dia (barra B007), e a outra imersa no concreto de relação a/c 0,80 com cura de 28 dias (B114).

A partir do princípio discutido na RAE, de que quanto maior for o grau de corrosão, ou a velocidade de corrosão, obtido durante a despassivação da armadura, menores vão ser as chances de alcançar a reconstituição da película de passivação.

Assim, as barras B007 e B114, se enquadram justamente neste contexto. Pois, de acordo com o gráfico da Figura 5.33, foram justamente estas barras que tiveram as menores resistências de polarização estimadas a partir do gráfico de Nyquist da EIE, dentro do seu grupo de relação a/c e cura. Ou seja, a velocidade de corrosão destas barras estava entre as maiores do grupo, o que dificulta a repassivação das armaduras. Porém, ressalta-se a importância do tipo de solução alcalina escolhida para garantir a eficácia do tratamento.

Na RAQ foi possível constatar com sucesso, a repassivação das armaduras através dos potenciais de corrosão em todas as soluções alcalinas estudadas. 


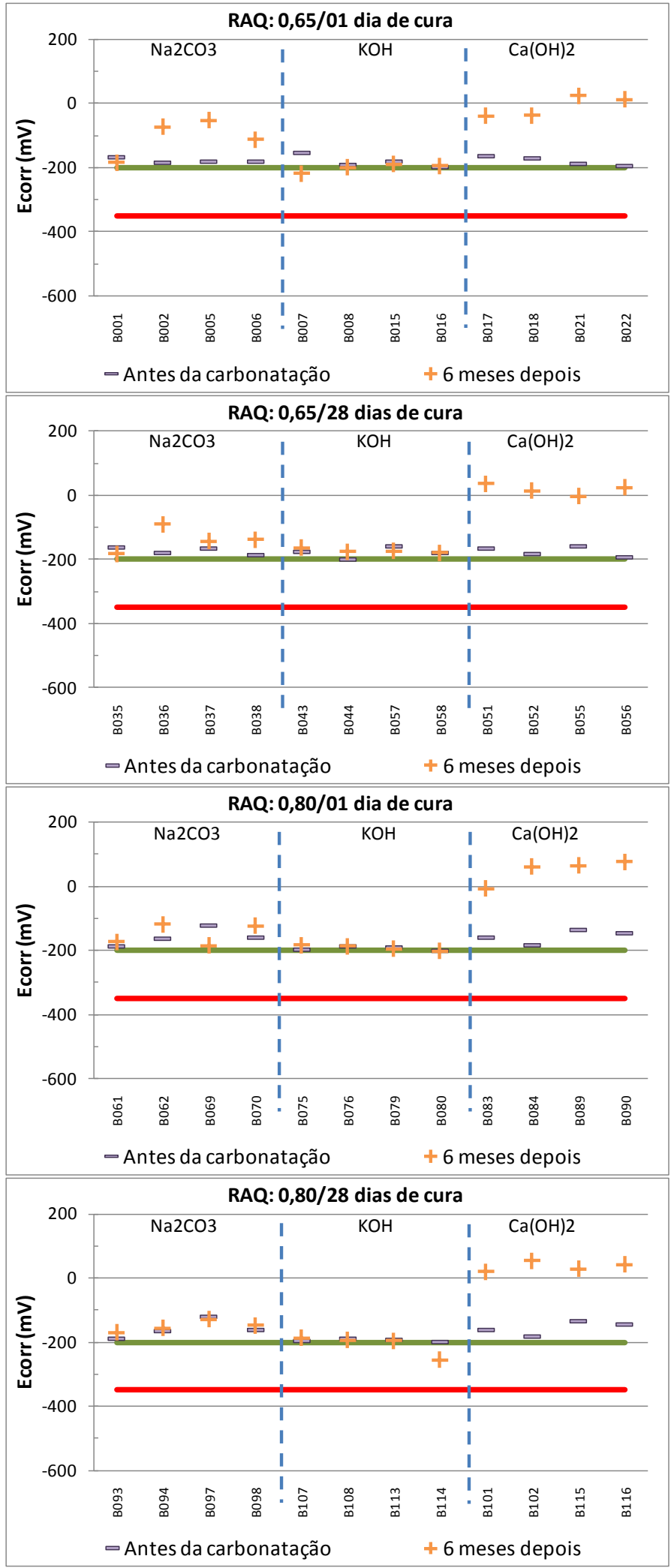

Figura 5.32. Leituras de potencial de corrosão nas barras dos corpos-de-prova antes da realização da carbonatação acelerada e após 6 meses da finalização do tratamento de RAQ. 


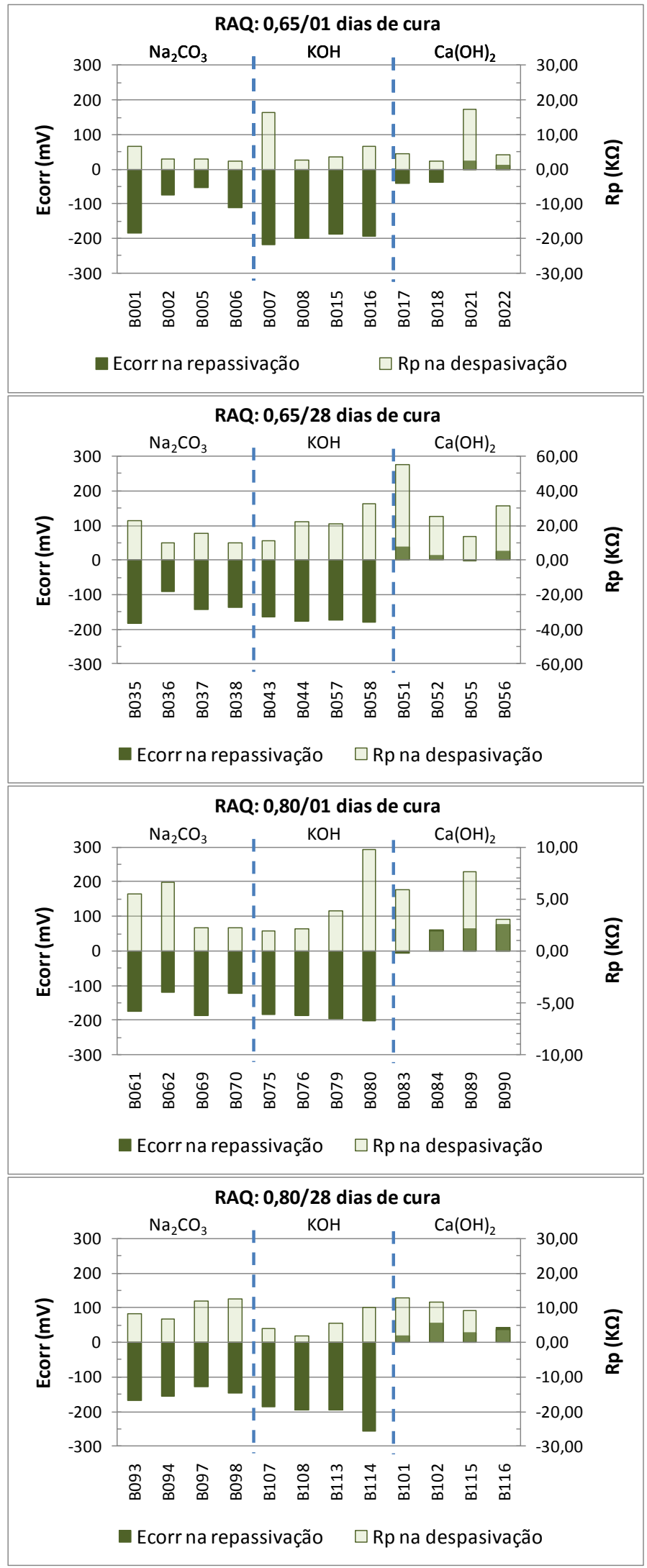

Figura 5.33. Leituras de potencial de corrosão (Ecorr) nas barras dos corpos-de-prova após 6 meses da finalização do tratamento de RAQ (período de repassivação), e os valores de resistência de polarização $(\mathrm{Rp})$ estimados pela EIE depois de finalizada a carbonatação (período de despassivação). 


\section{b.1) ANÁLISE DOS PARÂMETROS RELACIONADOS AO CONCRETO - REGIÃO DE ALTA FREQÜENNCIA (MAIOR DE $10^{4} \mathrm{HZ}$ ) NA EIE}

Na ampliação da Figura 5.34(a) à ampliação da Figura 5.37(a) é possível observar que a solução saturada de hidróxido de cálcio utilizada no tratamento, seguida da solução de carbonato de sódio, foram as que tiveram o maior aumento da resistência ôhmica do concreto (deslocamento para valores maiores de impedância real), quando comparado com os valores obtidos nos corpos-de-prova antes da carbonatação acelerada. O aumento da resistência ôhmica nos concretos realcalinizados com a solução de hidróxido de cálcio foi 10 vezes maior, do que a resistência ôhmica do concreto tratado com carbonato de sódio (em torno de 1.500 ohms), e 15 vezes maior do que a do concreto antes da carbonatação (aproximadamente $1.000 \mathrm{ohms}$ ). O tratamento com a solução de hidróxido de potássio apresentou uma resistência ôhmica (aproximadamente $250 \mathrm{ohms}$ ) bem inferior à do concreto antes do tratamento.

Coerentemente com o apresentado na ampliação da Figura 5.34(a) à ampliação da Figura 5.37(a), os diagramas de Bode dado por $|\mathrm{Z}|$ (da Figura 5.34(c) à Figura 5.37(c)), apresentaram o mesmo comportamento. Somente a solução de carbonato de sódio teve valores de resistência ôhmica próximos aos valores do concreto antes da carbonatação (entre 700 e 2.000 ohms). Na solução de hidróxido de potássio e de cálcio observou-se um deslocamento em relação ao concreto antes da carbonatação. A solução de hidróxido de potássio, conforme esperado, apresentou uma resistência ôhmica de aproximadamente 200 ohms, e a solução de hidróxido de cálcio de 10.000 ohms. 
$\underline{E I E}$

A análise apenas do comportamento da curva de impedância da Figura 5.34(a) à Figura 5.37(a) geraria dúvidas em relação à eficácia da reconstituição da película de passivação para a solução de carbonato de sódio. A solução de carbonato de sódio apresentou uma tendência ao fechamento do arco na região de baixa freqüência dos diagramas de Nyquist, característico de um estado ativo de corrosão. No entanto, ao analisar os diagramas de Bode, pode-se concluir que esta solução propiciou uma queda significativa na cinética da corrosão. Além de apresentar uma alta resistência ôhmica no diagrama de Bode dado por $|Z|$ em função da freqüência (da Figura 5.34(c) à Figura 5.37(c)), mantendo-se bem próxima à do concreto antes da carbonatação. O ângulo de fase obtido (entre $40^{\circ}$ e $50^{\circ}$ ), embora menor do que os obtidos no concreto antes da carbonatação (aproximadamente $80^{\circ}$ ) e da solução de hidróxido de potássio (entre $65^{\circ} \mathrm{e}$ $70^{\circ}$ ), ilustrado da Figura 5.34(b) à Figura 5.37(b), ainda assim é bem superior ao obtido na fase de despassivação das armaduras (Figura 5.5(b)), entre $15^{\circ}$ e $25^{\circ}$, confirmando o processo de passivação da armadura.

A utilização da solução de hidróxido de potássio foi a que apresentou o melhor comportamento na RAQ, com valores de ângulo de fase bem próximos aos de antes da carbonatação, e valores de impedância bastante altos.

Os resultados de impedância com a utilização da solução de hidróxido de cálcio foram superiores aos resultados obtidos antes da carbonatação, já os valores de ângulo de fase apresentaram resultados de inferiores aos valores de antes da carbonatação. Embora, como aconteceu com a solução de carbonato de sódio, o valor de ângulo de fase obtido $\left(50^{\circ}\right)$ tenha sido bem acima do obtido na fase de despassivação. 

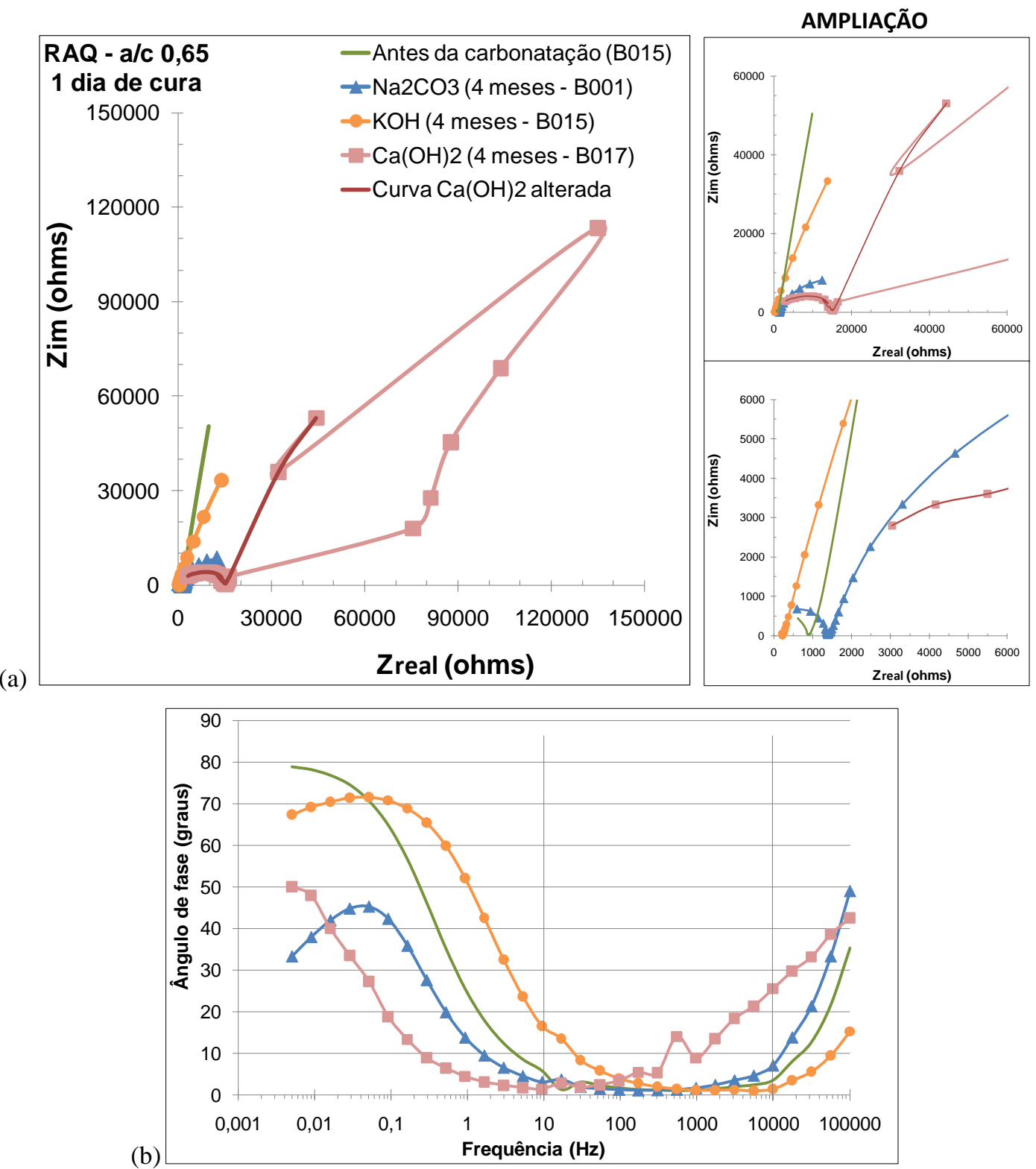

(b)

Frequência $(\mathrm{Hz})$

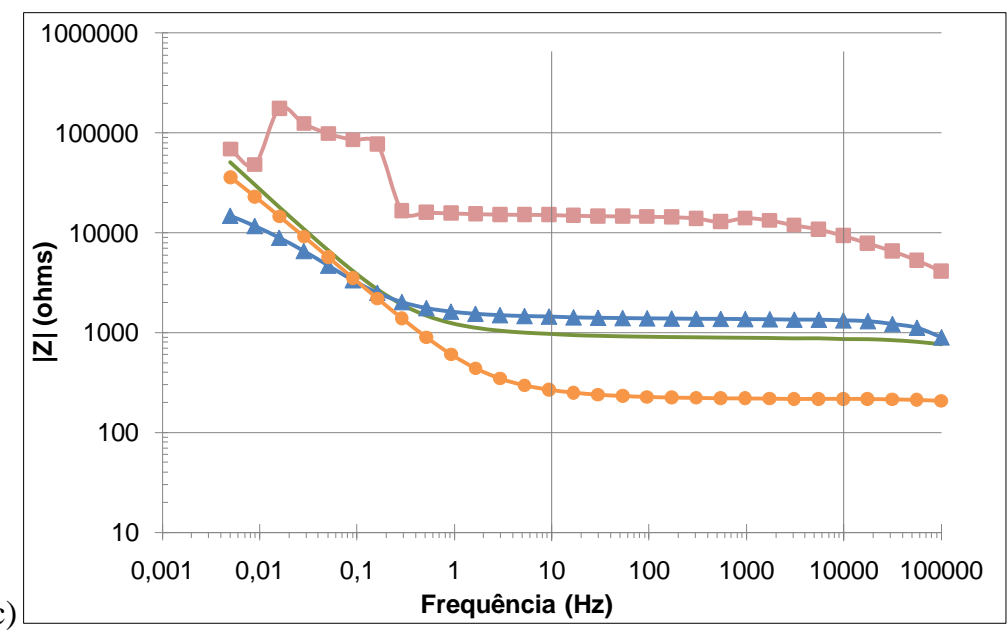

Figura 5.34. Evolução dos espectros de impedância obtidos nos concretos de relação a/c 0,65 e tempo de cura de 1 dia, antes de iniciada a carbonatação, e depois de 4 meses de finalizado o tratamento de RAQ, com o número da barra a que se referem (Bxxx): (a) Diagrama de Nyquist, (b) e (c) Diagramas de Bode. 

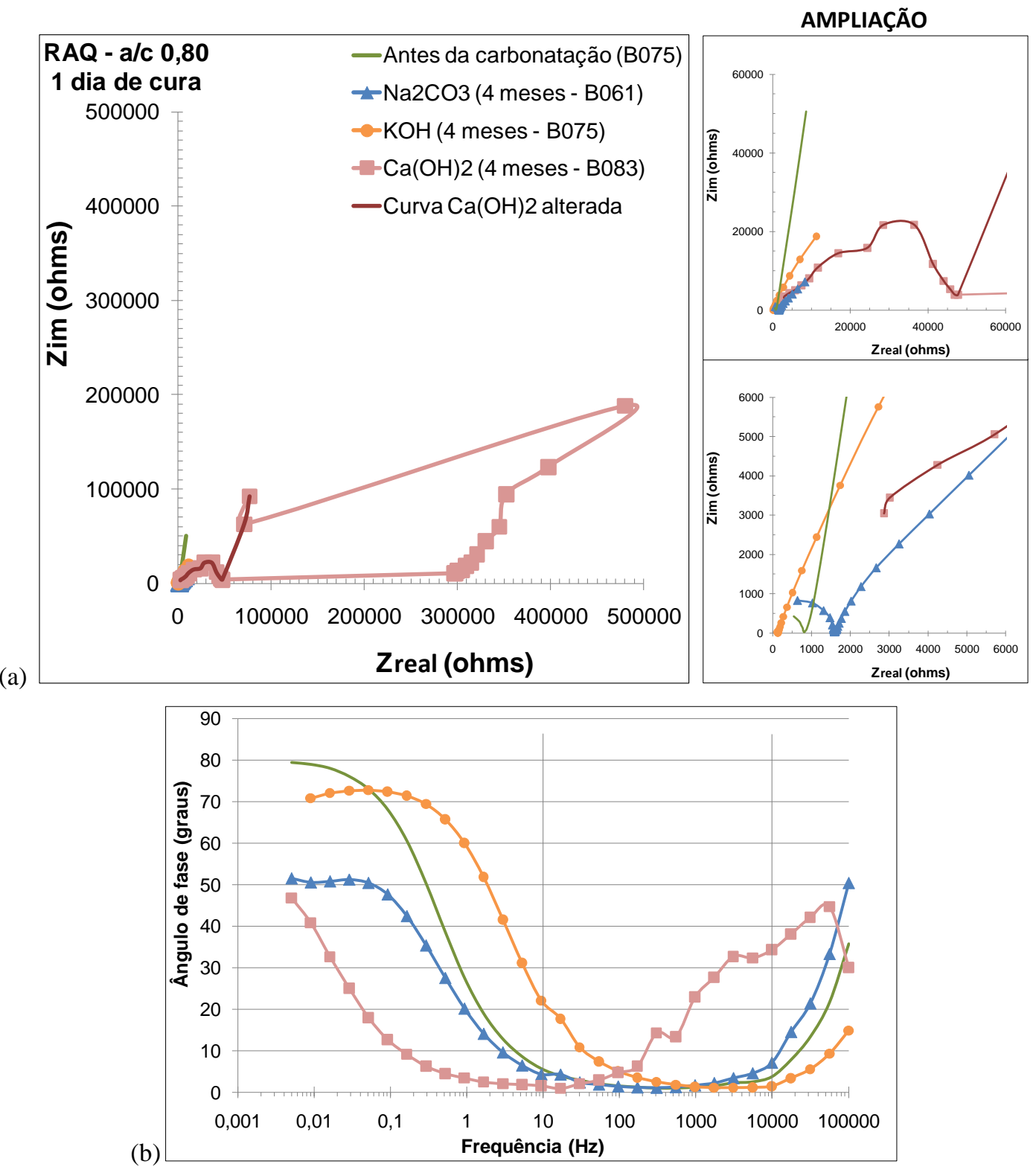

(b)

Frequência $(\mathrm{Hz})$

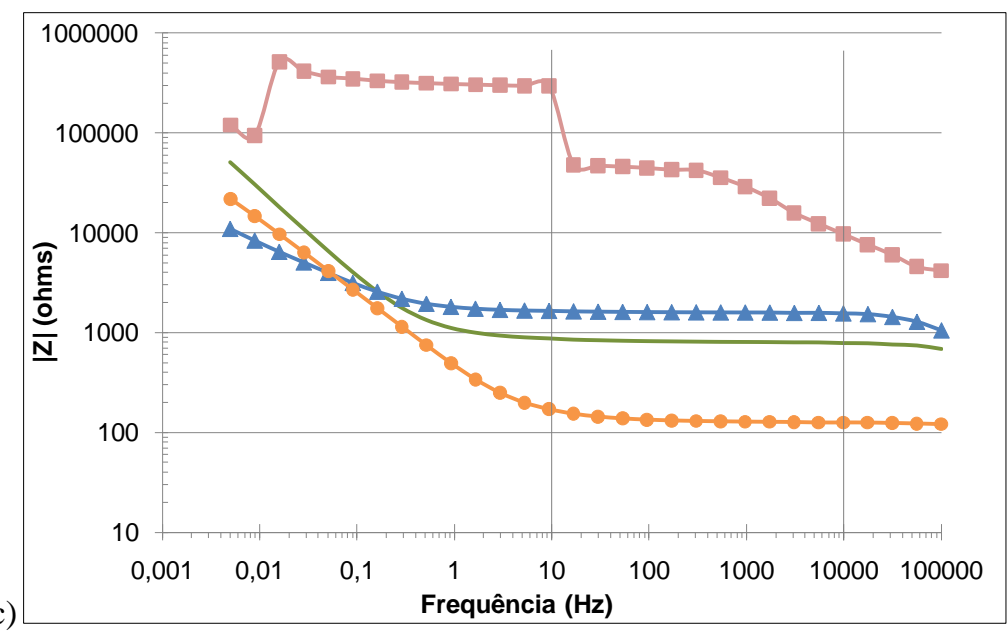

Figura 5.35. Evolução dos espectros de impedância obtidos nos concretos de relação a/c 0,80 e tempo de cura de 1 dia, antes de iniciada a carbonatação, e depois de 4 meses de finalizado o tratamento de RAQ, com o número da barra a que se referem $(\mathrm{Bxxx})$ : (a) Diagrama de Nyquist, (b) e (c) Diagramas de Bode. 

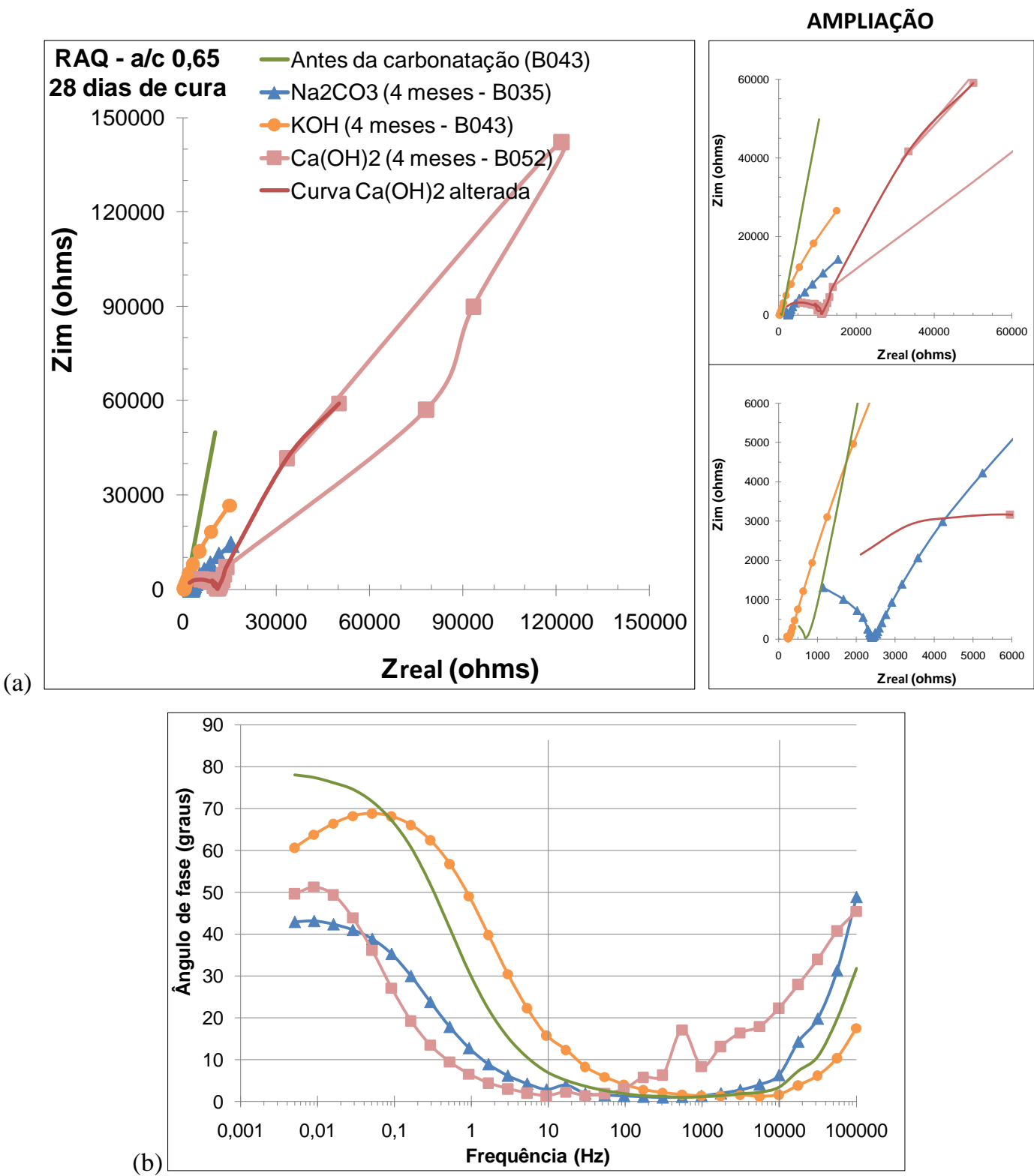

(b)

Frequência $(\mathrm{Hz})$

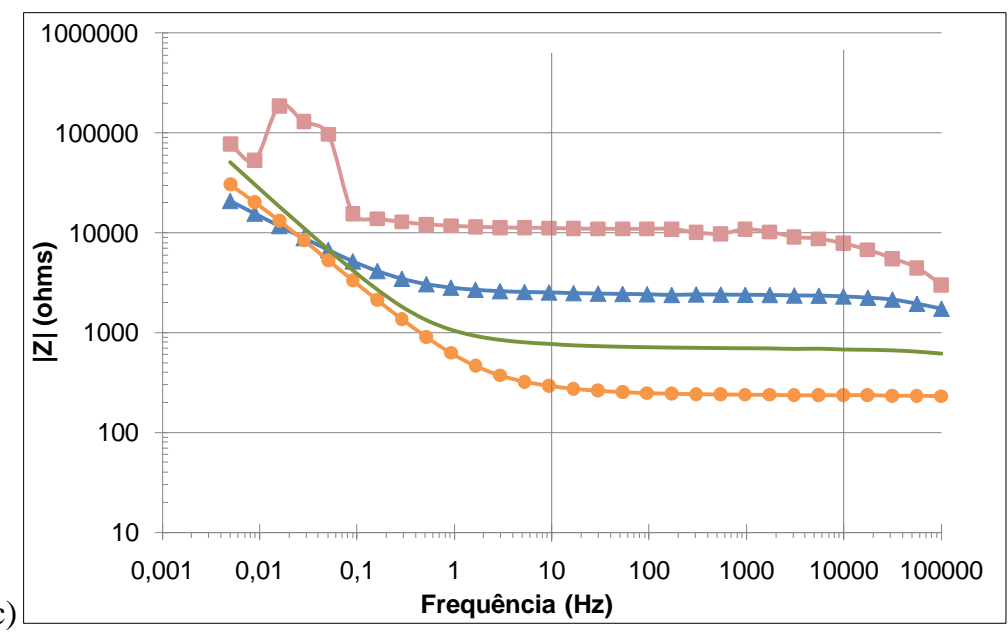

Figura 5.36. Evolução dos espectros de impedância obtidos nos concretos de relação a/c 0,65 e tempo de cura de 28 dias, antes de iniciada a carbonatação, e depois de 4 meses de finalizado o tratamento de RAQ, com o número da barra a que se referem (Bxxx): (a) Diagrama de Nyquist, (b) e (c) Diagramas de Bode. 

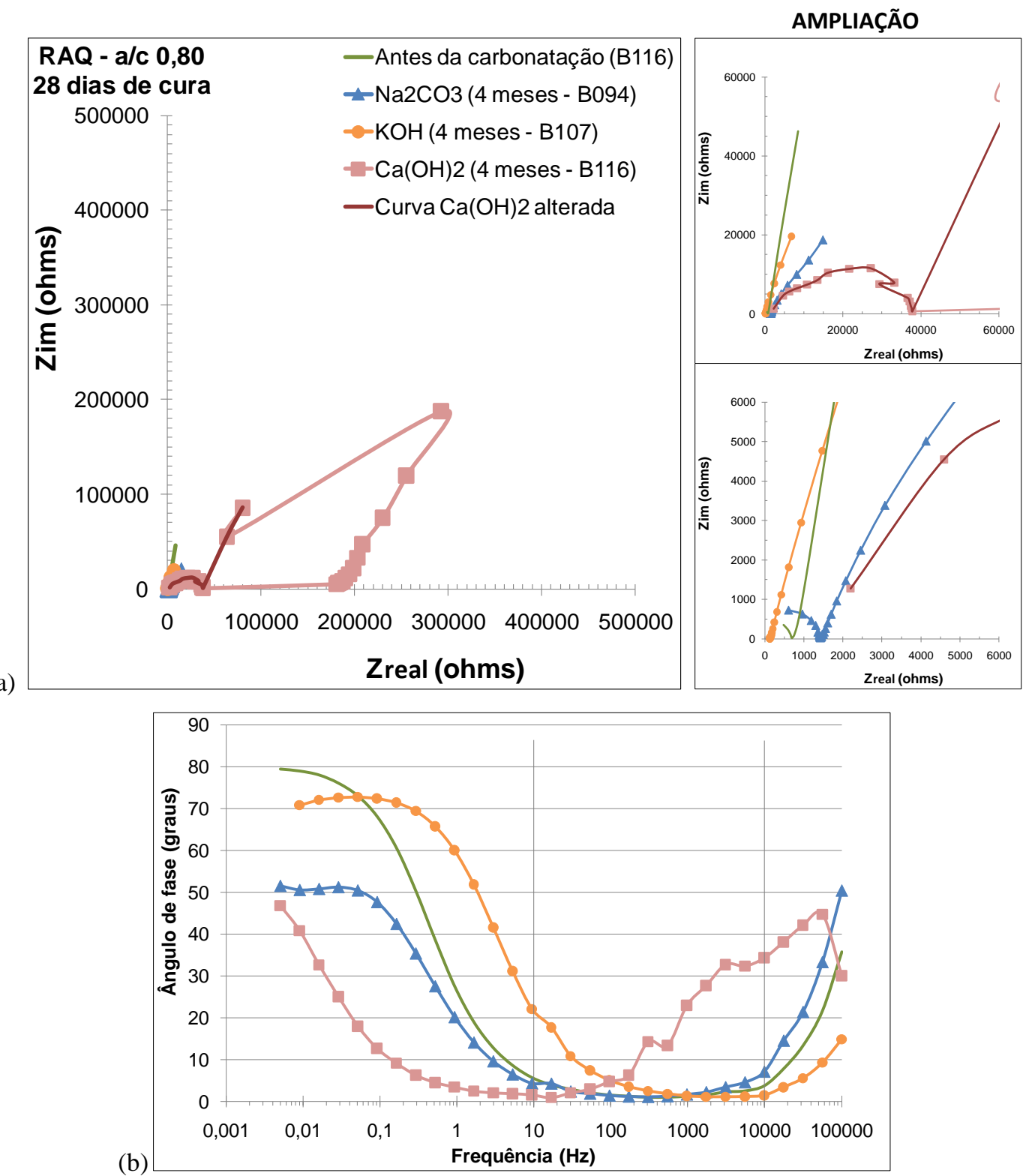

(b)

Frequência $(\mathrm{Hz})$

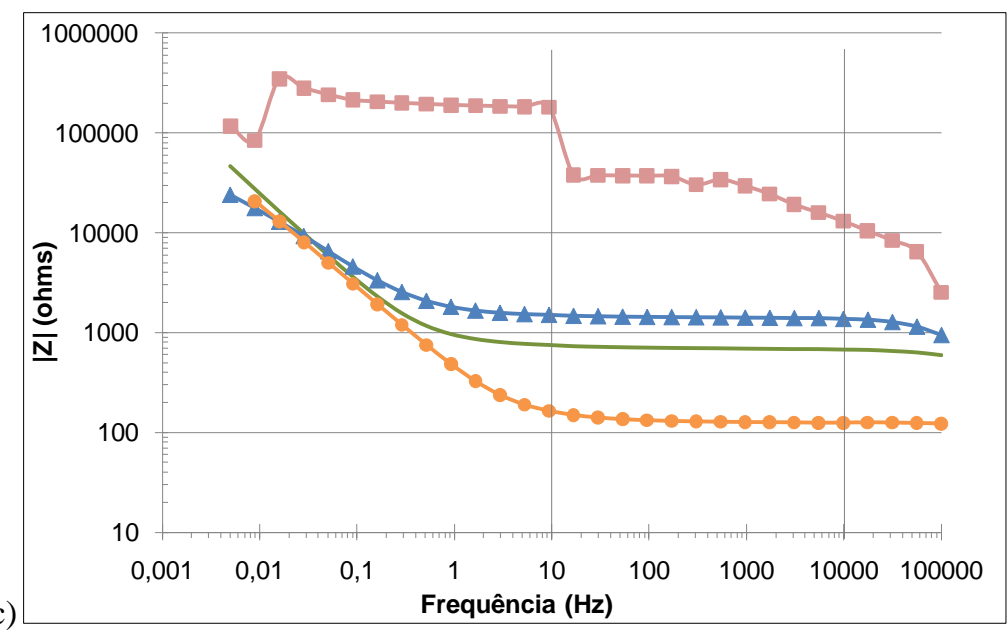

Figura 5.37. Evolução dos espectros de impedância obtidos nos concretos de relação a/c 0,80 e tempo de cura de 28 dias, antes de iniciada a carbonatação, e depois de 4 meses de finalizado o tratamento de RAQ, com o número da barra a que se referem (Bxxx): (a) Diagrama de Nyquist, (b) e (c) Diagramas de Bode. 


\subsection{ENSAIOS FÍSICOS}

Os corpos-de-prova cilíndricos de 50x50 mm definidos para estes ensaios foram moldados e preparados conforme a prescrição da RILEM - TC 116-PCD (RILEM, 1999), intitulada "Permeability of Concrete as a Criterion of its Durability”.

Para realização do ensaio foi necessário aguardar a finalização de todas as etapas de carbonatação acelerada e realcalinização química, de forma a realizar o ensaio com os corpos-de-prova nas mesmas idades (referência não carbonatado, referência carbonatado e os de referência realcalinizados). Para então verificar a ocorrência ou não da colmatação dos poros na matriz realcalinizada.

Durante a etapa de carbonatação acelerada, os corpos-de-prova de referência não carbonatados ficaram armazenados em caixas com a umidade controlada $(75 \pm 5 \%)$ através da utilização de soluções com sais (ASTM E104, 2002). O mesmo procedimento foi realizado para os corpos-de-prova de referência carbonatados durante a etapa de realcalinização dos demais. Estas caixas permaneceram em uma sala com a temperatura controlada de $23 \pm 3^{\circ} \mathrm{C}$ (Figura 5.38).

(a)
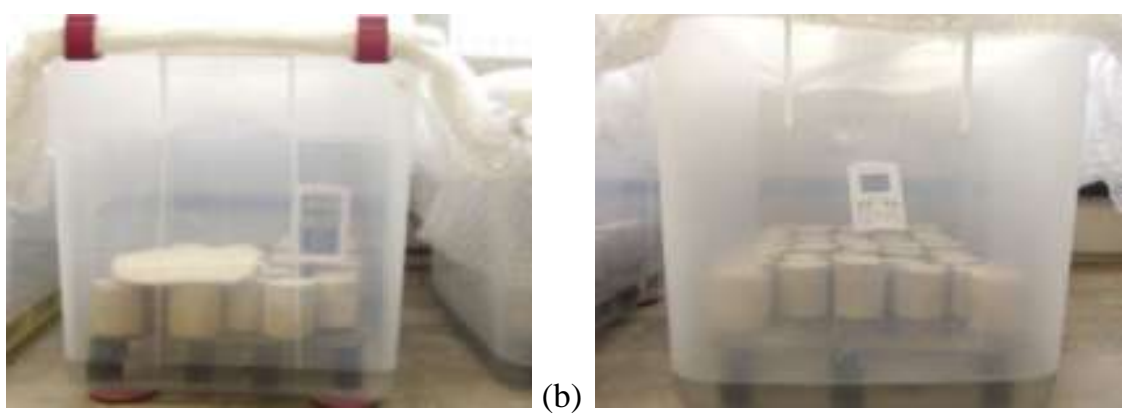

Figura 5.38. Caixas plásticas com solução de NaCl saturado (ASTM E104, 2002) para

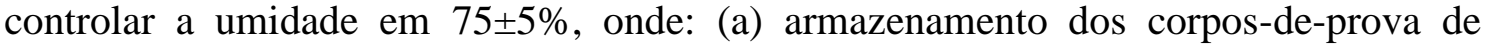
referência não carbonatados, (b) armazenamento dos corpos-de-prova de referência carbonatados.

Para impedir a carbonatação dos corpos-de-prova de referência não carbonatados, no interior da caixa onde estavam armazenados, foram colocados recipientes com hidróxido de bário de forma a absorver o $\mathrm{CO}_{2}$ do seu interior (Figura 5.39). 


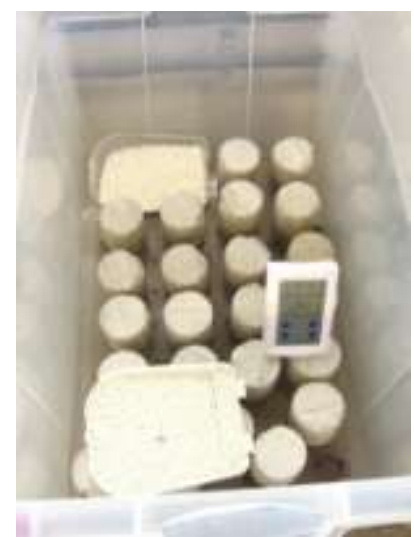

Figura 5.39. Recipiente de hidróxido de bário no interior das caixas plásticas dos corpos-de-prova de referência não carbonatados para evitar a carbonatação das amostras no interior das mesmas.

A carbonatação total dos cilindros de 50x50 mm demorou 21 semanas, e em seguida foram separados os corpos-de-prova de referência carbonatados, sendo os demais corpos-de-prova imediatamente imersos nas soluções alcalinas estudadas $\left(\mathrm{Na}_{2} \mathrm{CO}_{3}, \mathrm{KOH}\right.$ e $\left.\mathrm{Ca}(\mathrm{OH})_{2}\right)$ a fim de realcalinizar todo o seu cobrimento (Figura 5.40).
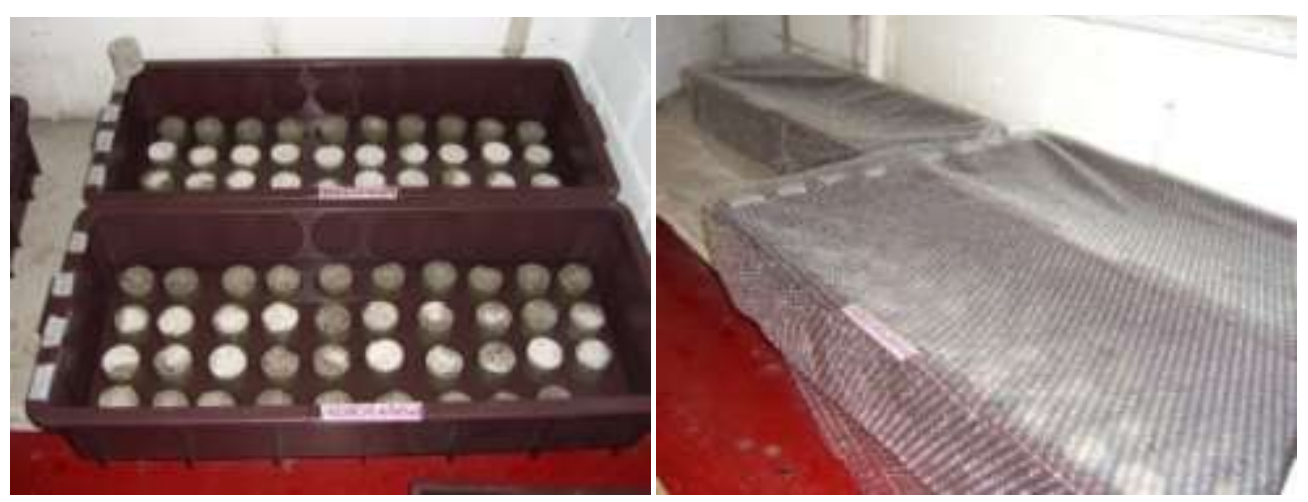

Figura 5.40. Corpos-de-prova imersos nas soluções alcalinas, e cobertos para não perder água para o ambiente.

Depois de três semanas de tratamento foram realizadas as primeiras medidas de profundidade de realcalinização, e pode-se observar que apenas os de relação a/c 0,80 e com cura de 1 dia imerso na solução de $\mathrm{KOH}$ estavam completamente realcalinizados (Figura 5.41), as demais profundidades estão expressas no gráfico da Figura 5.42. 

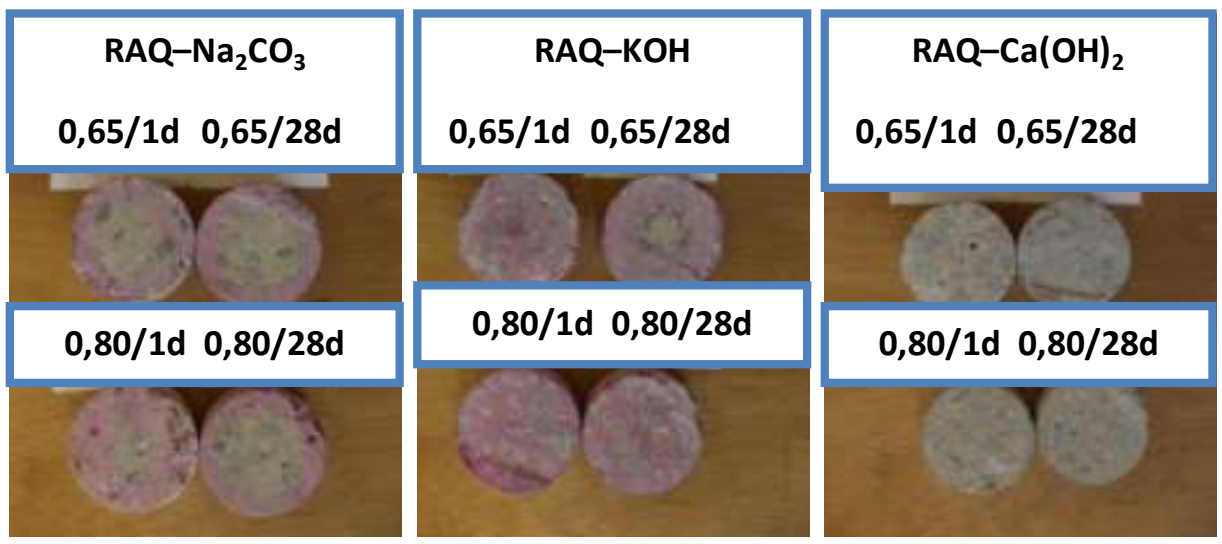

Figura 5.41. Corpos-de-prova serrados para medir a profundidade de realcalinização depois de 3 semanas.

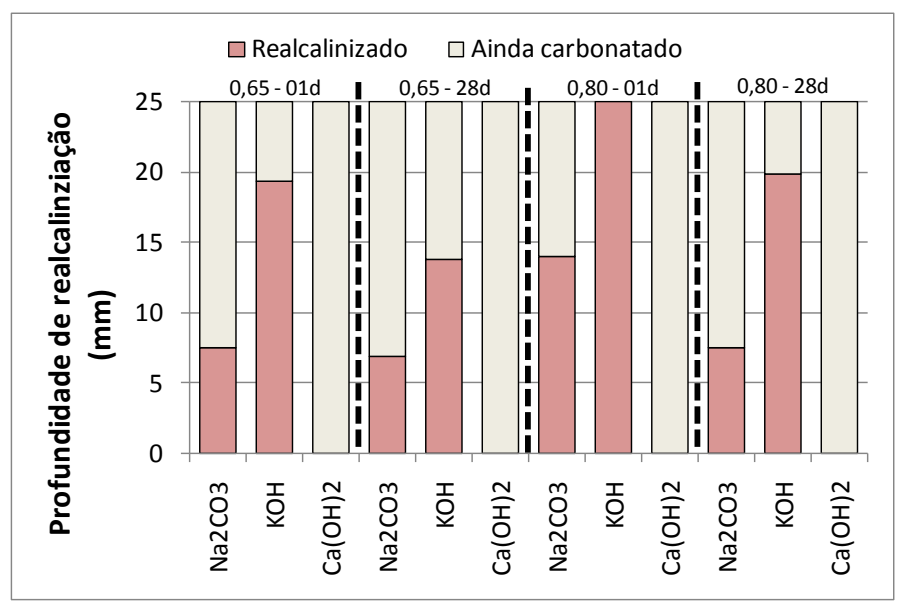

Figura 5.42. Profundidade de realcalinização nos corpos-de-prova estudados em cada uma das três soluções alcalinas definidas depois de 3 semanas de tratamento.

A segunda medição ocorreu depois de 9 semanas de tratamento, e ainda assim alguns corpos-de-prova não estavam realcalinizados totalmente (Figura 5.43 e Figura 5.44).
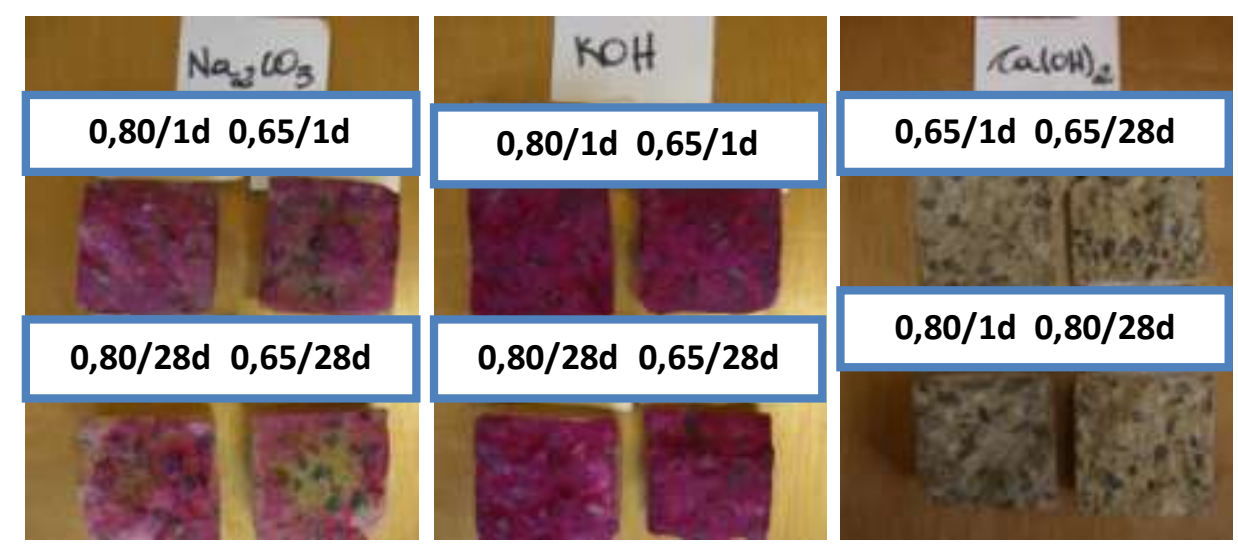

Figura 5.43. Corpos-de-prova realcalinizados com as soluções de $\mathrm{Na}_{2} \mathrm{CO}_{3}, \mathrm{KOH}$ e $\mathrm{Ca}(\mathrm{OH})_{2}$ fraturados e aspergidos com a solução de fenolftaleína. 


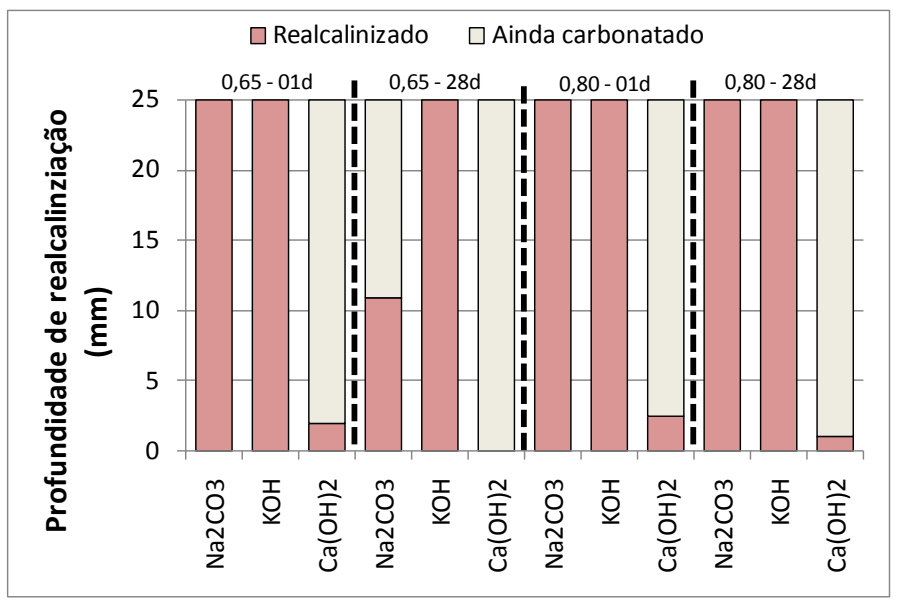

Figura 5.44. Profundidade de realcalinização nos corpos-de-prova estudados em cada uma das três soluções alcalinas definidas depois de 9 semanas de tratamento.

Ao completar 14 semanas de tratamento, foi possível observar a total realcalinização do corpo-de-prova de a/c 0,65 com 28 dias de cura imerso na solução de $\mathrm{Na}_{2} \mathrm{CO}_{3}$. No entanto, os corpos-de-prova imersos na solução de $\mathrm{Ca}(\mathrm{OH})_{2}$ ainda não tinham alcançado sequer a margem de $5 \mathrm{~mm}$ de profundidade de realcalinização. Mesmo apresentando este comportamento, os ensaios de absorção de água por capilaridade e por imersão também foram realizados nestes corpos-de-prova.

Durante todo o período da realcalinização, todas as soluções tinham o seu valor de $\mathrm{pH}$ monitorado semanalmente, permitindo constatar a queda do valor do $\mathrm{pH}$, devido a entrada dos íons alcalinos no interior dos corpos-de-prova, e então realizar a troca da solução quando a queda do seu valor de $\mathrm{pH}$ passasse em 1 ponto. Durante o processo de realcalinização, mais uma vez fica clara a eficiência da solução de $\mathrm{KOH}$ em relação à velocidade de realcalinização do concreto carbonatado.

Por outro lado, a realcalinização química através da solução de hidróxido de cálcio mostrou-se ineficiente na realcalinização do concreto carbonatado. Uma vez que passado 14 semanas ainda não havia conseguido atingir uma profundidade de realcalinização satisfatória para a sua inclusão nos ensaios de absorção por capilaridade e por imersão.

5.2.1. Ensaio de Absorção E Ascensão CAPIlar da Água POR CAPILARIDADE

A realização deste ensaio tem o objetivo de verificar se a realcalinização com as soluções de carbonato de sódio e de hidróxido de potássio e cálcio favorecem a durabilidade do concreto. Com este ensaio será verificado se a absorção e a ascensão 
capilar de corpos-de-prova realcalinizados sofrem redução, quando comparados os de referência não carbonatados e os carbonatados, além de verificar se há alguma diferença em relação à solução alcalina utilizada durante a realcalinização.

Ao final dos processos de realcalinização os corpos-de-prova foram secos em estufa de $40^{\circ} \mathrm{C}$ até a obtenção da sua constância de massa. Logo após a obtenção da constância de massa, os corpos-de-prova tiveram as suas laterais seladas com silicone (Figura 5.45).

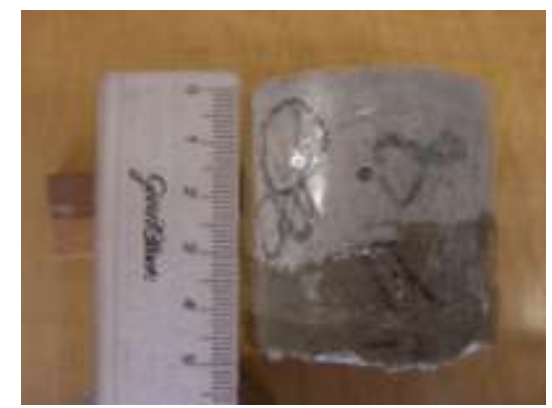

Figura 5.45. Corpo-de-prova serrado e com a sua lateral selada com silicone.

Durante o ensaio, os corpos-de-prova cilíndricos tiveram a face serrada (por estar livre de desmoldante) imersa em um recipiente com uma película de água de $3 \mathrm{~mm}$ durante 24 horas (Figura 5.46).
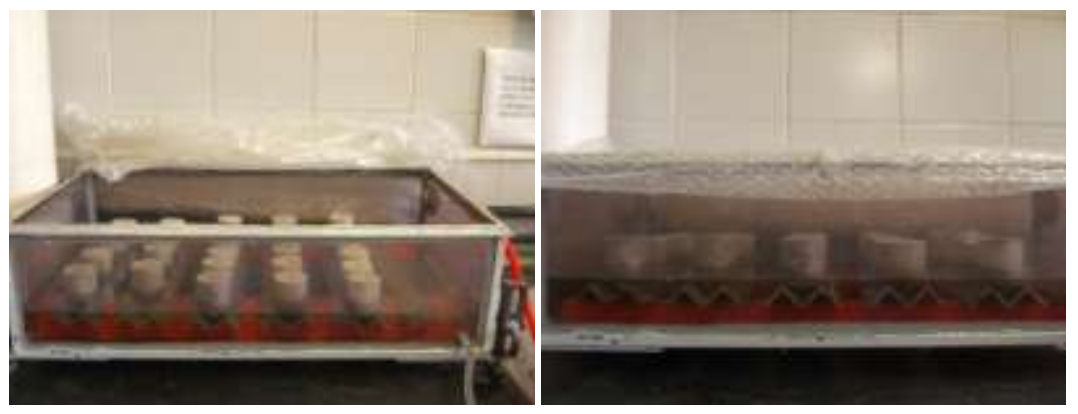

Figura 5.46. Corpos-de-prova imersos em película de água de $3 \mathrm{~mm}$.

Durante a imersão foram realizadas medições de aumento de massa nos intervalos de 10 minutos, 1, 4 e 24 horas. Ao final das 24 horas de ensaio, os corpos-deprova imersos na película de $3 \mathrm{~mm}$ de água foram rompidos axialmente e verificada a altura da absorção capilar.

Nos corpos-de-prova com cura de apenas 1 dia a ascensão capilar atingiu o topo dos mesmos, impossibilitando a comparação entre as diferentes condições estabelecidas para o ensaio. Alguns corpos-de-prova com cura de 28 dias também apresentaram ascensão capilar até o topo, no entanto este efeito só foi observado em alguns dos realcalinizados. 
Na Figura 5.47 é possível observar os corpos-de-prova de relações a/c 0,65 e 0,80 (ambos com 28 dias de cura) rompidos axialmente, assim como a marcação da ascensão capilar destacada.

(a)

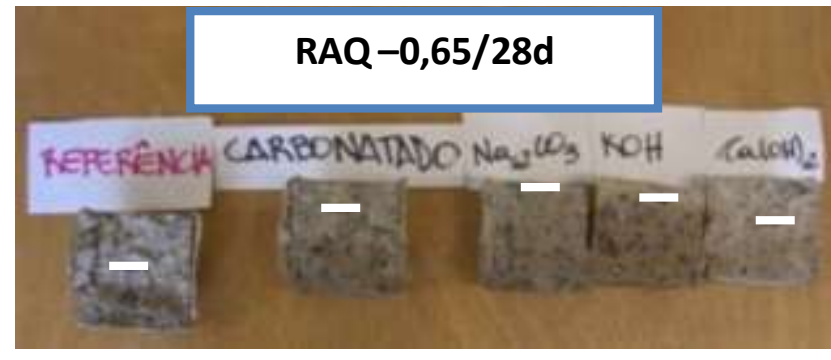

(b)

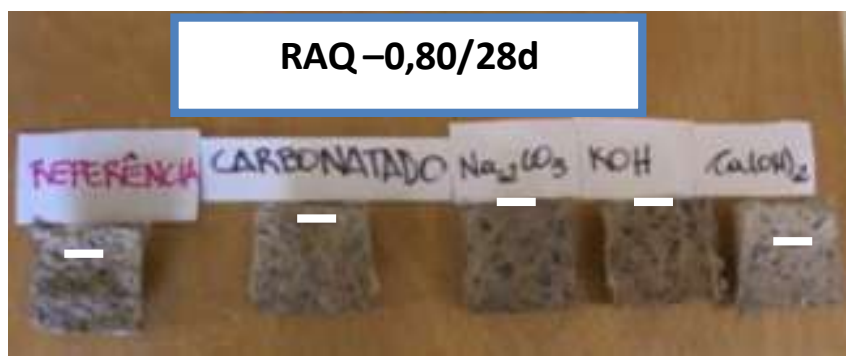

Figura 5.47. Ascensão capilar dos corpos-de-prova de referência não carbonatados, referência carbonatados e de referência realcalinizados ionicamente pelas soluções de carbonato de sódio $\left(\mathrm{Na}_{2} \mathrm{CO}_{3}\right)$, hidróxido de potássio $(\mathrm{KOH})$ e cálcio $\left(\mathrm{Ca}(\mathrm{OH})_{2}\right)$. (a) Corpos-de-prova de relação a/c 0,65 com 28 dias de cura e (b) corpos-de-prova de relação a/c 0,80 com 28 dias de cura.

Com o gráfico (Figura 5.48) referente à ascensão capilar da Figura 5.47 é possível observar com maior clareza a ascensão capilar em cada uma das situações estudas.

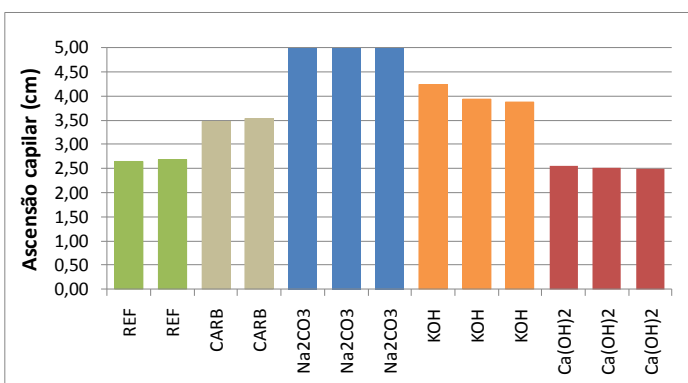

(a)

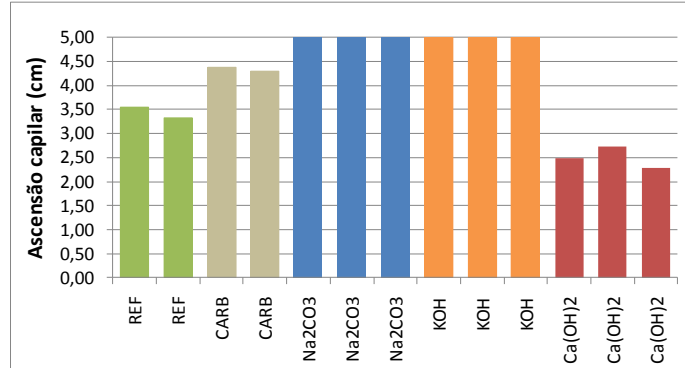

(b)

Corpos-de-prova a/c 0,80 - 28 dias de cura

Figura 5.48. Gráfico da ascensão capilar dos corpos-de-prova de referência não carbonatados, referência carbonatados e de referência realcalinizados ionicamente pelas soluções de carbonato de sódio $\left(\mathrm{Na}_{2} \mathrm{CO}_{3}\right)$, hidróxido de potássio $(\mathrm{KOH})$ e cálcio $\left(\mathrm{Ca}(\mathrm{OH})_{2}\right)$. (a) Corpos-de-prova de relação a/c 0,65 com 28 dias de cura e (b) corposde-prova de relação a/c 0,80 com 28 dias de cura.

Nos gráficos da Figura 5.48 é possível observar o aumento da ascensão capilar da água nos concretos carbonatados e realcalinizados com carbonato de sódio e hidróxido de potássio. A solução de hidróxido de cálcio, mesmo não proporcionando a 
realcalinização do concreto, provocou uma diminuição da ascensão capilar quando comparado com o concreto carbonatado, e no caso da relação a/c 0,80 , apresentou valores inferiores ao do concreto de referência.

Em relação às soluções de realcalinização de carbonato de sódio e hidróxido de potássio, apenas na relação a/c 0,65 (Figura 5.48.(a)) foi possível observar que a solução de carbonato de sódio provocou uma maior ascensão capilar da água.

Através da norma da RILEM TC 116-PCD (RILEM, 1999) foi possível calcular a absorção capilar de cada um dos corpos-de-prova (Figura 5.49).

(a)
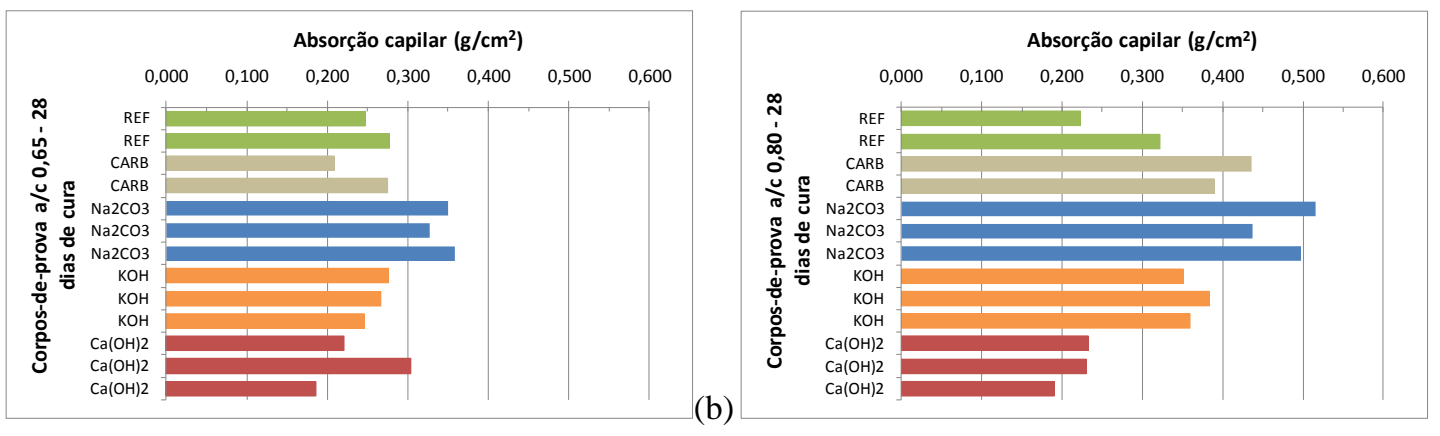

Figura 5.49. Absorção capilar dos corpos-de-prova de referência não carbonatados (REF), dos carbonatados (CARB) e dos realcalinizados nas soluções de carbonato de sódio $\left(\mathrm{Na}_{2} \mathrm{CO}_{3}\right)$, hidróxido de potássio $(\mathrm{KOH})$ e cálcio $\left(\mathrm{Ca}(\mathrm{OH})_{2}\right)$. (a) Corpos-de-prova de relação a/c 0,65 com 28 dias de cura e (b) corpos-de-prova de relação a/c 0,80 com 28 dias de cura.

Com o cálculo da absorção capilar, ou seja, do total de água absorvido quando imerso na película de água de 3mm, é possível observar que os corpos-de-prova realcalinizados com carbonato de sódio apresentaram também uma absorção de água maior do que os realcalinizados com hidróxido de potássio. Os realcalinizados com hidróxido de potássio apresentaram um comportamento bastante semelhante aos de referência e aos carbonatados, variando entre 0,247 e 0,276 g/ $\mathrm{cm}^{2}$ para os de a/c 0,65 e entre 0,350 e $0,384 \mathrm{~g} / \mathrm{cm}^{2}$ para os de a/c 0,80 .

$\mathrm{Na}$ relação a/c 0,65 todos os corpos-de-prova apresentação maior ascensão capilar do que os corpos-de-prova de referência. No entanto, quando analisamos a absorção capilar os corpos-de-prova carbonatados e os realcalinizados com a solução de hidróxido de potássio apresentaram um comportamento bem parecido com os de referência. Somente os corpos-de-prova realcalinizados com carbonato de sódio absorveram mais água do que o de referência, e os realcalinizados com o hidróxido de cálcio apresentaram uma absorção capilar um pouco menor.

Já na relação a/c 0,80 por ser um concreto mais poroso, os resultados obtidos foram mais díspares. Evidenciando a colmatação dos poros devido à 
carbonatação. Somente os corpos-de-prova realcalinizados com a solução de hidróxido de cálcio mostraram uma regressão desta colmatação, obtendo de absorção bem parecida com o do concreto de referência.

Os estudos realizados por Al-Kadhimi et al. (1996), apud Mietz (1998), Banfill (1996) e Yeih e Chang (2005), constataram uma diminuição do total de água absorvida e da absorção capilar após a realcalinização eletroquímica dos concretos carbonatados. A diferença de resultados entre esta pesquisa e a de Al-Kadhimi et al. (1996), apud Mietz (1998), e Banfill (1996) pode ser devido a natureza da realcalinização, e a possível geração de elementos químicos diferentes devido a aplicação de corrente elétrica no interior do concreto.

\subsubsection{ENSAIO DE ABSORÇÃo de ÁGUA POR IMERSÃo E FERVURA}

Assim como para o ensaio de absorção de água por capilaridade, este ensaio teve a finalidade de observar as mudanças ocorridas no interior dos concretos realcalinizados em relação aos concretos de referência não carbonatados e os carbonatados, além de constatar se há alguma diferença quando utilizada uma solução alcalina diferente. Ao final dos processos de carbonatação e realcalinização dos corposde-prova foi dado início ao ensaio de absorção de água por imersão de acordo com a norma da NBR 9778 (ABNT, 2005).

Todo o processo de imersão e fervura foi realizado em um recipiente próprio para cura térmica, no qual os corpos-de-prova ficam em banho-maria e a temperatura da água é controlada por um termostato (Figura 5.50).

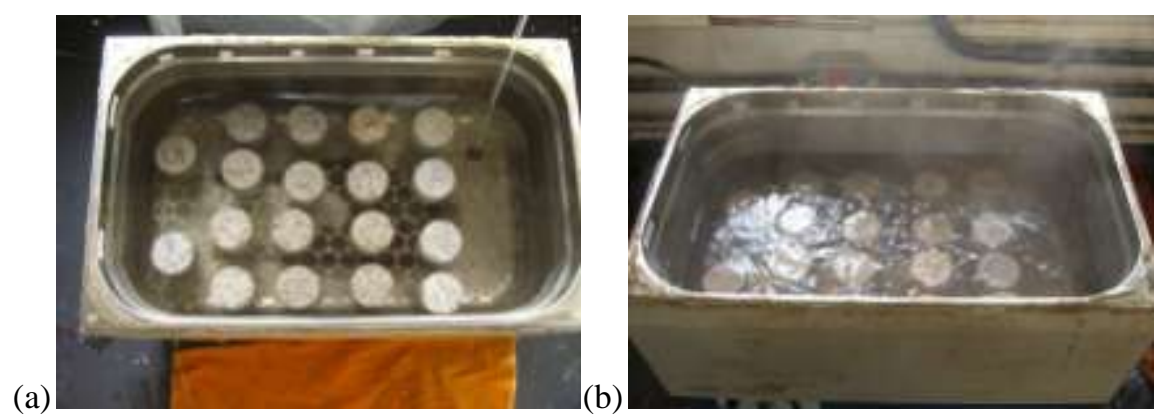

Figura 5.50. Recipiente utilizado para a (a) imersão e (b) fervura dos corpos-de-prova.

A pesagem hidrostática foi realizada através de um sistema onde incluía uma balança normal de resolução de pelo menos $0,05 \%$ da massa a ser determinada, sobre a qual estava uma barra de ferro, e sob a mesma uma cesta metálica imersa em recipiente com água (Figura 5.51). Antes da colocação dos corpos-de-prova na cesta 
metálica era realizada a tara na balança a fim de descontar o peso das barras de ferro e da cesta metálica, possibilitando desta maneira a obtenção da massa imersa em água, e assim obter o índice de vazios.

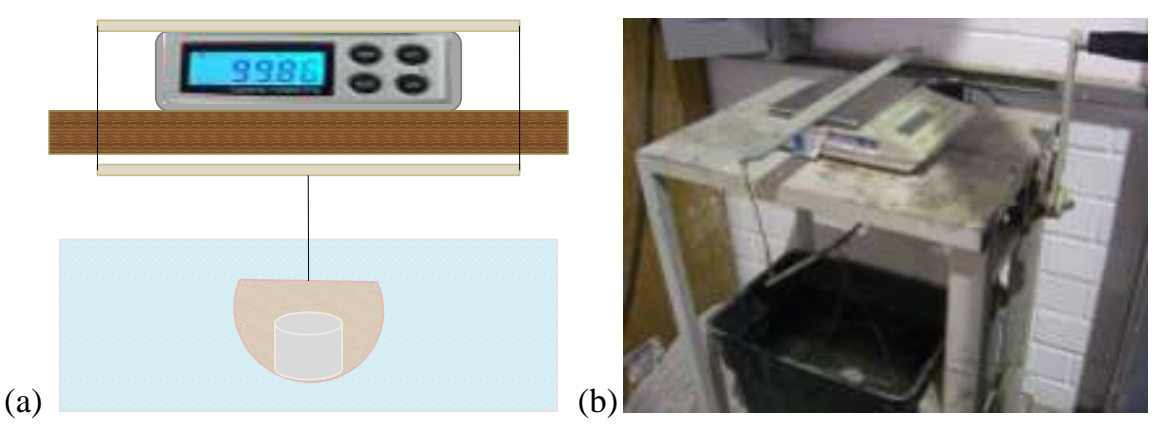

Figura 5.51. (a) Esquema realizado para medir a massa dos corpos-de-prova imersos em água. (b) Fotografia da "balança hidrostática" utilizada no ensaio.

Com as medidas realizadas foi possível calcular, de acordo com a NBR 9778 (ABNT, 2005), a quantidade de água absorvida e o índice de vazios dos corpos-de-prova de relação a/c 0,65 e 0,80 com 28 dias de cura. Os corpos-de-prova com cura de 1 dia, assim como para o ensaio de absorção capilar, foram descartados. Desta maneira, só serão apresentados os resultados referentes aos corpos-de-prova com 28 dias de cura. A Figura 5.52 ilustra os valores de absorção de água obtidos no ensaio de imersão e fervura. No gráfico (a) estão representados os corpos-de-prova de a/c 0,65 e no (b) os de a/c 0,80 .

(a)
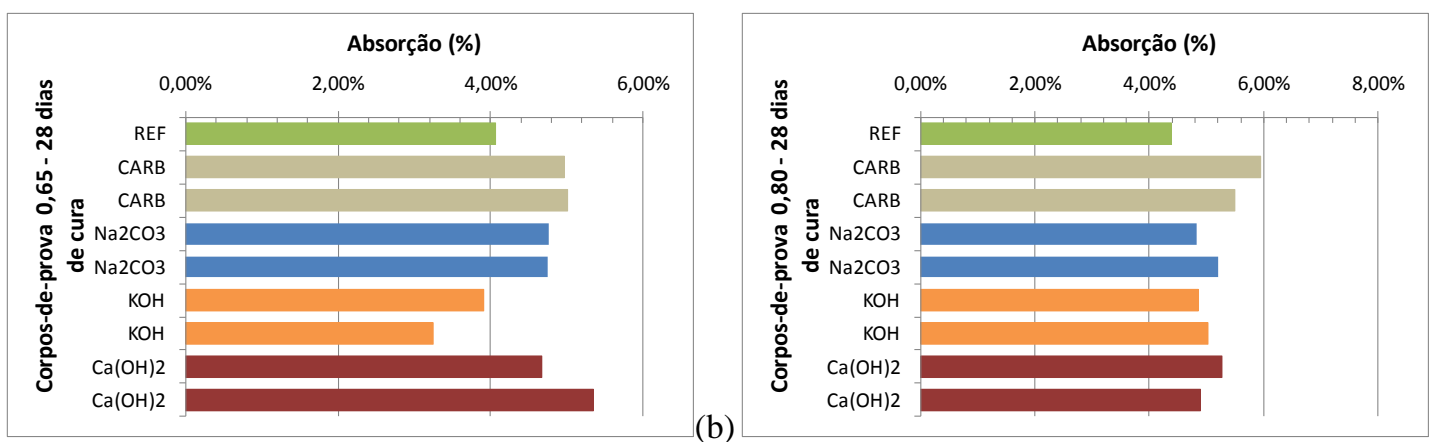

Figura 5.52. Absorção por imersão e fervura dos corpos-de-prova de referência não carbonatados (REF), dos carbonatados (CARB) e dos realcalinizados nas soluções de carbonato de sódio $\left(\mathrm{Na}_{2} \mathrm{CO}_{3}\right)$, hidróxido de potássio $(\mathrm{KOH})$ e cálcio $\left(\mathrm{Ca}(\mathrm{OH})_{2}\right)$. (a) Corpos-de-prova de relação a/c 0,65 com 28 dias de cura e (b) corpos-de-prova de relação a/c 0,80 com 28 dias de cura.

Nos corpos-de-prova de relação a/c 0,80 , o comportamento dos realcalinizados foi bastante semelhante entre si e entre os de referência não carbonatados, mostrando um decréscimo da absorção de água quando comparado com os carbonatados. No entanto, quando comparamos o gráfico dos de relação a/c 0,65 , somente os realcalinizados com a solução de hidróxido de potássio é que tiveram a 
mesma absorção dos de referência. Enquanto os realcalinizados com a solução de carbonato de sódio e com o hidróxido de cálcio apresentaram uma maior absorção de água.

Com a pesagem dos corpos-de-prova na balança hidrostática foi possível calcular o índice de vazios em cada uma das situações estudadas (Figura 5.53). Neste momento é que foi possível observar para os corpos-de-prova de relação a/c 0,65 a diminuição do índice de vazios quando realcalinizados com a solução de hidróxido de potássio. Nos corpos-de-prova de relação a/c 0,80 foi possível observar a diminuição do índice de vazios apenas em relação aos corpos-de-prova carbonatados.

(a)

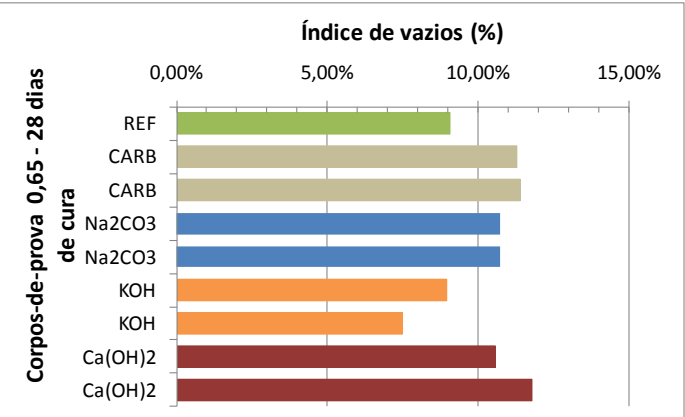

(b)

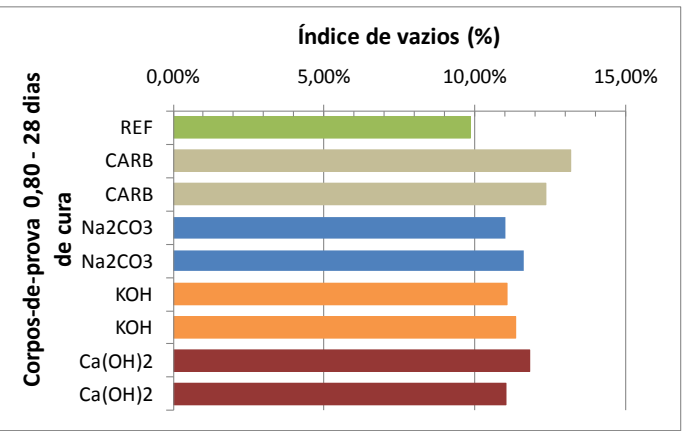

Figura 5.53. Índice de vazios obtidos através do ensaio de absorção por imersão e fervura dos corpos-de-prova de referência não carbonatados (REF), dos carbonatados (CARB) e dos realcalinizados nas soluções de carbonato de sódio $\left(\mathrm{Na}_{2} \mathrm{CO}_{3}\right)$, hidróxido de potássio $(\mathrm{KOH})$ e cálcio $\left(\mathrm{Ca}(\mathrm{OH})_{2}\right)$. (a) Corpos-de-prova de relação a/c 0,65 com 28 dias de cura e (b) corpos-de-prova de relação a/c 0,80 com 28 dias de cura.

Os resultados de índice de vazios (Figura 5.53) não corresponderam com o relatado no levantamento bibliográfico. Pois, é consenso que a carbonatação provoca a colmatação dos poros do concreto em razão da conversão do hidróxido de cálcio em carbonato de cálcio, sendo os cristais deste último maiores. Não foi possível realizar a repetição deste ensaio, uma vez que os corpos-de-prova sobressalentes para este ensaio foram utilizados durante a verificação das profundidades de carbonatação e de realcalinização química.

\subsubsection{DURABILIDADE DA REALCALINIZAÇÃO QUÍMICA}

A durabilidade da técnica de RAQ foi realizada através da comparação da velocidade da carbonatação dos corpos-de-prova de referência não carbonatados (mantidos em caixas com umidade e temperatura controlada, além de ausência de gás carbônico), com a da recarbonatação dos corpos-de-prova realcalinizados nas diferentes soluções alcalinas. A primeira medida da frente de carbonatação dos corpos-de-prova 
foi realizada após 2 semanas dos mesmos no interior da câmara de carbonatação acelerada, com umidade relativa e temperatura controlada $\left(75 \pm 5 \%\right.$ de U.R. e $\left.23 \pm 3^{\circ} \mathrm{C}\right)$ e teor de gás carbônico de $10 \%$.

No momento da medição da profundidade de carbonatação dos corpos-deprova de referência não carbonatados e da recarbonatação dos corpos-de-prova realcalinizados, também foi averiguado se os corpos-de-prova que permaneceram nas caixas haviam sofrido alguma carbonatação no seu interior. Conforme é possível observar na Figura 5.54, corpos-de-prova de referência não carbonatados (posição 2) não haviam sofrido qualquer carbonatação (Figura 5.54 (b) e (d)), ou sofreram uma carbonatação mínima (Figura 5.54 (a) e (b)) de $1 \mathrm{~mm}$ para o concreto de a/c 0,65 e cura de 1 dia, e de $2 \mathrm{~mm}$ o de a/c 0,80 e cura de 1 dia.

Na Figura 5.54, os corpos-de-prova estão organizados da seguinte maneira: na posição 1 estão os corpos-de-prova realcalinizados através das soluções de carbonato de sódio; na posição 2 estão os corpos-de-prova de referência não carbonatados antes da carbonatação; na posição 3 estão os corpos-de-prova realcalinizados através das soluções de hidróxido de potássio; e na posição 4 estão os corpos-de-prova de referência que foram carbonatados.
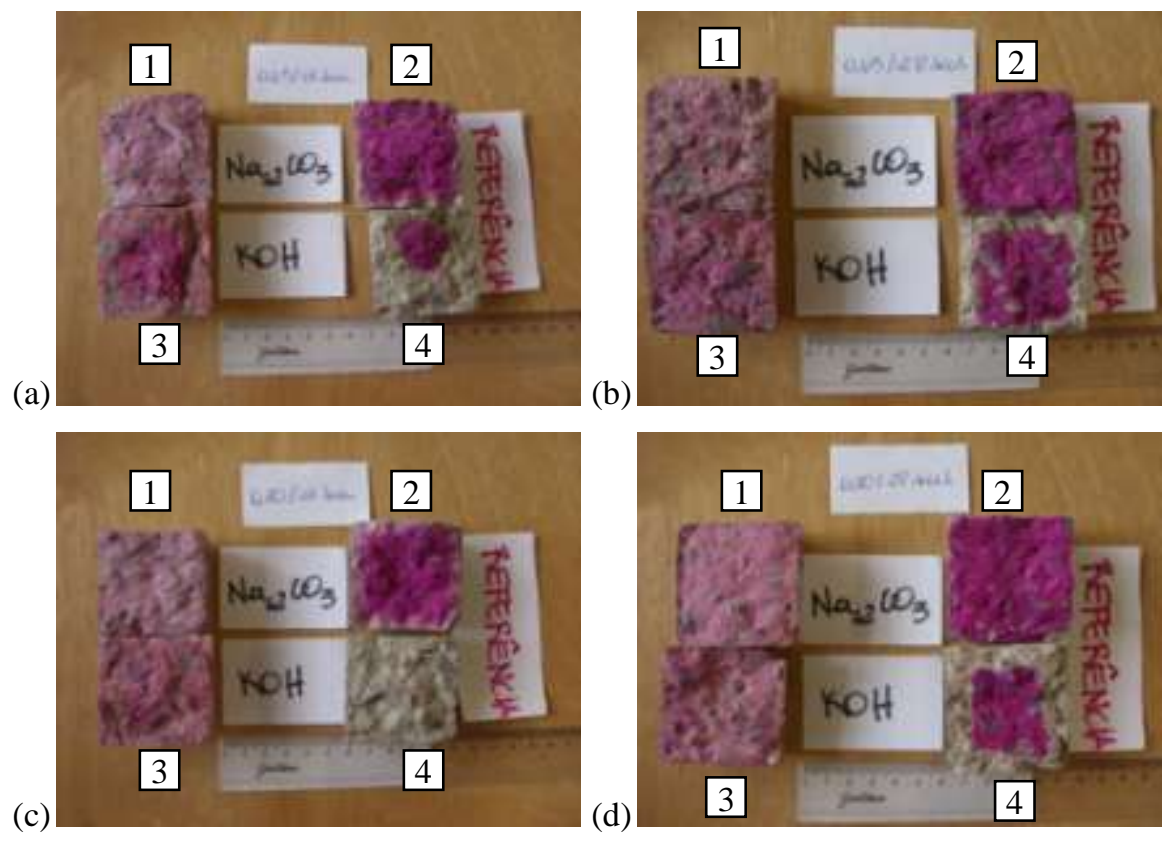

Figura 5.54. Corpos-de-prova depois de duas semanas na câmara de carbonatação: (a) relação a/c 0,65 com 1 dia de cura, (b) relação a/c 0,65 com 28 dias de cura, (c) relação a/c 0,80 com 1 dia de cura, e (d) relação a/c 0,80 com 28 dias de cura.

No entanto, conforme é possível observar na Figura 5.55, com duas semanas de carbonatação acelerada já foi possível constatar a diferença da velocidade de 
carbonatação entre os corpos-de-prova não carbonatados e os realcalinizados. Os corpos-de-prova de relação a/c 0,80 e cura de 1 dia não carbonatados já apresentavam o concreto totalmente carbonatado, o corpos-de-prova de a/c 0,65 e cura de 1 dia faltava menos de $3 \mathrm{~mm}$ para sua total carbonatação, seguido do concreto de a/c ,80 e 0,65 com 28 dias de cura. Já os corpos-de-prova realcalinizados não apresentavam qualquer indício da frente de recarbonatação, qualquer que fosse a relação a/c ou tempo de cura.

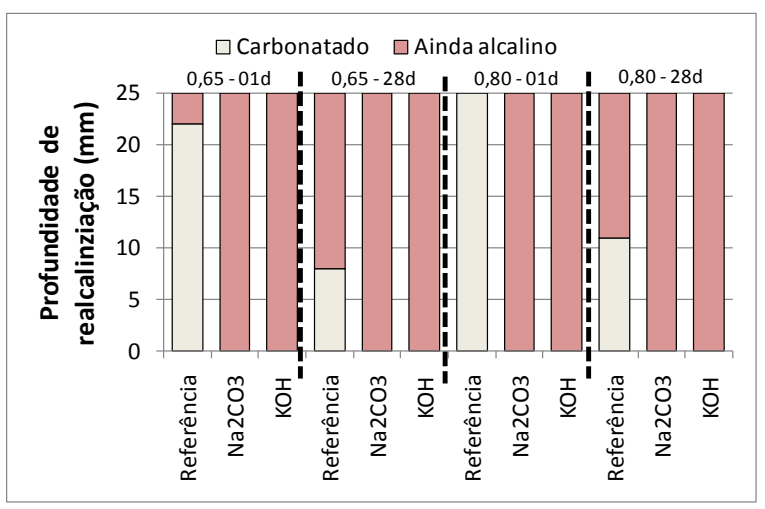

Figura 5.55. Profundidade de carbonatação dos corpos-de-prova de referência, realcalinizados com carbonato de sódio e hidróxido de potássio, depois de duas semanas.

O segundo conjunto de corpos-de-prova foi fraturado com a idade de 45 dias. E ainda assim os corpos-de-prova realcalinizados não apresentavam qualquer indício da frente de recarbonatação, enquanto os corpos-de-prova não carbonatados anteriormente encontravam-se totalmente carbonatados, com exceção dos corpos-deprova de relação a/c 0,65 e cura de 28 dias, o qual ainda apresentava 2,5mm para a sua total carbonatação.

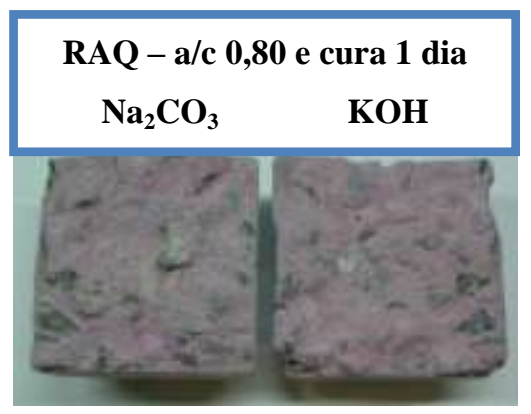

Figura 5.56. Profundidade de recarbonatação dos corpos-de-prova realcalinizados quimicamente com carbonato de sódio e hidróxido de potássio, depois de 45 dias no interior da câmara de carbonatação.

As medições da carbonatação seriam continuadas até a verificação frente de carbonatação nos corpos-de-prova realcalinizados. No entanto, em razão de problemas técnicos inerentes ao desenvolvimento deste trabalho, a câmara de carbonatação não pode ser utilizada até a finalização deste trabalho. 


\section{CONCLUSÕES}

\subsection{CONSIDERaÇõeS}

As conclusões são baseadas e fundamentadas no presente trabalho, visando esclarecer lacunas em relação à viabilização da nova técnica de realcalinização, a química (RAQ). Este estudo também realizou comparações entre a nova técnica e a atual técnica de realcalinização já existente no mercado, a eletroquímica (RAE).

\subsubsection{CONDIÇÕES DA ARMAdURA Ao FinAlizar o TratAMENTO}

A reconstituição da película de passivação no concreto é uma etapa lenta e importante. Como foi discutido em diversos momentos, nem sempre os responsáveis pela realização da recuperação da estrutura realizam qualquer tipo de monitoramento a fim de constatar se este problema foi sanado.

Já há algum tempo vem-se alertando para os cuidados que se devem ter com a técnica de realcalinização eletroquímica. Pois, nem sempre a técnica de realcalinização eletroquímica é eficiente na repassivação da armadura. Nos casos onde a carbonatação já atingiu a armadura, e a mesma encontra-se em alto grau de corrosão, a RAE pode não ter a eficácia desejada ou esperada.

Nesta pesquisa, os resultados obtidos indicam que na situação onde a corrosão ainda se encontra na fase de iniciação, a RAE e RAQ responderam eficazmente à repassivação das armaduras. Este bom resultado foi válido tanto para a solução alcalina de carbonato de sódio, comumente utilizada no mercado, como também para soluções ainda não usuais, como os hidróxidos de potássio e cálcio.

Em alguns casos, o potencial de corrosão das barras não ficou na faixa de classificação desprezível, ou seja, com potencial de corrosão superior à -200 mV. Porém, em todas as situações, pelo menos uma das quatro barras estudadas conseguiu atingir esta faixa. É provável que a dificuldade em obter potenciais de baixa probabilidade de corrosão para todas as barras tenha ocorrido mais em razão de algum fator intrínseco da barra do que em razão da ineficácia das realcalinizações estudadas. Porém, é importante ressaltar, que, de acordo com a bibliografia estudada, o estágio de propagação no qual a corrosão se encontra vai ser determinante para o sucesso ou 
insucesso da realcalinização. Assim como na RAE, é provável que a RAQ não proporcione a repassivação da armadura no caso da mesma se encontrar em um estágio avançado de corrosão.

Porém, é evidente que a repassivação da armadura está inevitavelmente ligada ao tipo de solução alcalina utilizada no tratamento.

$\underline{\text { Solução alcalina de carbonato de sódio (concentração de 1M) }}$

Esta solução apresentou resultados satisfatórios, embora tenha provocado o esfarelamento da camada de cobrimento do concreto logo no início da realcalinização química. É possível que este esfarelamento possa ser evitado utilizando uma concentração de carbonato de sódio inferior a 1M. A velocidade de realcalinização do concreto carbonatado com a utilização desta solução, em comparação com a solução de hidróxido de potássio, foi um pouco mais lenta (63 dias, contra os 47 com a solução de $\mathrm{KOH})$. No entanto, a sua capacidade de elevar os potenciais de corrosão à probabilidade de $5 \%$ foi levemente mais eficaz do que a de $\mathrm{KOH}$, principalmente na RAQ.

Em relação ao ensaio de espectroscopia de impedância eletroquímica (EIE), a solução alcalina de carbonato de sódio apresentou um bom desempenho. Ao analisar os resultados de impedância na região de baixa frequiência, constatou-se que os resultados de resistência ôhmica do $|Z|$ e do ângulo de fase foram um pouco mais baixo do que os valores obtidos antes da despassivação, mas somente para a RAQ, pois, na RAE os valores ficaram bem próximos ao de antes da carbonatação.

$\underline{\text { Solução alcalina de hidróxido de potássio (concentração de 2,5M) }}$

A solução de hidróxido de potássio, de acordo com o levantamento bibliográfico realizado, é considerada a solução alcalina mais propícia para utilizar na realcalinização química. No entanto, os potencias de probabilidade de corrosão alcançados com a RAQ foram inferiores ao obtidos com a solução de $\mathrm{Na}_{2} \mathrm{CO}_{3}$. $\mathrm{Na}$ RAE, os potenciais de corrosão obtidos foram bem semelhantes ao da solução de carbonato de sódio.

Nos ensaios de EIE, esta solução foi a que apresentou resultados de impedância, de $|Z|$ e de ângulo de fase mais próximos aos da barra antes da despassivação, principalmente na RAQ. Na RAE o comportamento das soluções de $\mathrm{KOH}$ e de carbonato de sódio foi bem parecido. 
$\underline{\text { Solução alcalina de hidróxido de cálcio (concentração saturada) }}$

A solução saturada de hidróxido de cálcio é uma alternativa inédita para utilizar na realcalinização, seja eletroquímica ou química. Os resultados obtidos na repassivação da armadura foram bastante satisfatórios. No entanto, quando se constata que esta solução não apresentou a capacidade de promover o aumento do $\mathrm{pH}$ do cobrimento, utilizando a fenolftaleína como indicador colorimétricos de $\mathrm{pH}$, o emprego desta solução deve ser cuidadosa. Apesar de ser contraditório, o fato de não ter ocorrido a realcalinização da camada de cobrimento e mesmo assim ter ocorrido a repassivação da armadura, é explicado pela analise do $\mathrm{pH}$ na região ao redor da barra através da fenolftaleína. De acordo com os resultados de profundidade de realcalinização, foi possível observar que a região ao redor da barra foi realcalinizada, e que, provavelmente, esta condição foi suficiente para repassivar as barras.

Portanto, foi justamente esta solução alcalina, a que conseguiu aumentar os valores de potencial de corrosão a níveis superiores aos obtidos antes da carbonatação, durante a fase de passivação da armadura. Dentre as análises realizadas neste trabalho, não foram obtidas explicações plausíveis para explicar este bom desempenho do hidróxido de cálcio como solução alcalina na repassivação das armaduras, tanto na RAE quanto na RAQ. Portanto, ressalta-se a necessidade de estudos mais específicos para uma melhor avaliação desta solução alcalina.

Nos ensaios de EIE, os resultados obtidos também foram bastante significativos. Na RAE, os resultados de impedância e de $|Z|$ obtidos foram bem semelhantes aos obtidos com as outras soluções alcalinas estudadas. Apenas os resultados de ângulo de fase deixaram um pouco a desejar, pois na relação a/c 0,65 o ângulo máximo obtido foi de $50^{\circ}$, enquanto na relação a/c 0,80 e nas outras soluções alcalinas chegaram a $70^{\circ}$ e $80^{\circ}$. Na RAQ, os resultados de impedância e $|Z|$ foram melhores do que os obtidos com as outras soluções, apenas os resultados de ângulo de fase se mostraram um pouco aquém dos resultados de antes da carbonatação e da solução de $\mathrm{KOH}$, entretanto, sempre bem próximo aos valores obtidos com a solução de carbonato de sódio.

\subsubsection{CONDIÇÕES DO CONCRETO AO FinALIZAR O TRATAMENTO}

A avaliação das condições do concreto com a finalização do tratamento foi bastante útil e elucidativa ao analisar os resultados obtidos com as diferentes soluções empregadas. Em todos os corpos-de-prova testados, a resistência ôhmica do concreto 
após a carbonatação foi maior do que no concreto de referência. Este comportamento confirma o que é relatado na bibliografia, onde a carbonatação, do ponto de vista apenas do concreto, proporciona o fechamento dos poros do concreto.

Estes resultados sobre a condição do concreto também deveriam ser apoiados pelos resultados de absorção por capilaridade e imersão por fervura, no entanto, os resultados obtidos neste trabalho não foram congruentes com os relatos da bibliografia levantada. Assim como não foram congruentes com o comportamento analisado com base nos demais ensaios realizados neste estudo. Portanto, a análise da condição do concreto após o tratamento foi baseada apenas nos resultados de resistência ôhmica, pois, os mesmos foram bastante congruentes com o relatado na bibliografia.

\section{$\underline{\text { Solução alcalina de carbonato de sódio (concentração de 1M) }}$}

Tanto no tratamento realizado com a RAE quanto na RAQ, esta solução alcalina proporcionou melhorias na qualidade do concreto tratado quando comparado ao concreto de referência. No entanto, não superou a melhoria do concreto após a carbonatação, ressaltando que esta análise é do ponto de vista da condição do concreto. Estas afirmações são apoiadas pelos ensaios de EIE, os quais mostraram uma resistência ôhmica do concreto tratado, seja com RAE ou com RAQ, maior do que no concreto de referência e menor do que no concreto carbonatado. Ou seja, o ingresso deste tipo de solução associada à aplicação de corrente, proporcionou o fechamento dos poros do concreto e o aumento da sua resistência ôhmica quando comparado ao concreto de referência. Em relação ao concreto carbonatado, apenas a solução alcalina de hidróxido de cálcio apresentou maior resistência ôhmica após a RAQ, nas demais soluções empregadas, nenhuma apresentou maiores resultados do que no concreto carbonatado após a RAQ.

Este comportamento sugere que o concreto carbonatado quando submetido à RAQ e a RAE utilizando as soluções alcalinas de carbonato de sódio e hidróxido de potássio, possivelmente, apresenta alterações nos seus compostos hidratados que por sua vez alteram a matriz porosa do concreto. Em estudos futuros, recomenda-se que ensaios mais específicos sejam abordados, principalmente a porosimetria por intrusão de mercúrio, para uma análise mais aprofundada na porosidade do concreto. Conforme descrito anteriormente, os resultados de absorção por capilaridade e imersão por fervura obtidos neste trabalho não permitiram uma análise congruente da condição do concreto após o tratamento com a RAE e com a RAQ. 
Solução alcalina de hidróxido de potássio (concentração de 2,5M)

Nos ensaios de EIE, a utilização da solução de hidróxido de potássio na RAE e na RAQ apresentou uma resistência ôhmica do concreto menor do que no concreto de referência. Ou seja, este ensaio mostrou que provavelmente os compostos formados em razão da RAQ e da RAE com esta solução ocupam um espaço menor do que os compostos formados originalmente durante a hidratação do cimento Porém, com o arranjo experimental utilizado neste trabalho, não é possível afirmar se este efeito ocorre somente em razão da aplicação da solução alcalina no concreto carbonatado, ou se ocorreria também no caso da aplicação no concreto não carbonatado.

Conforme descrito anteriormente, os resultados obtidos com o ensaio de absorção por capilaridade não corroboram com os resultados obtidos na EIE. Pois, apesar de apresentar uma absorção capilar maior do que no concreto de referência (antes da carbonatação), a ascensão capilar também foi maior, assim como ocorreu na solução de carbonato de sódio.

\section{$\underline{\text { Solução alcalina de hidróxido de cálcio (concentração saturada) }}$}

Tanto na RAE quanto na RAQ, a utilização desta solução, associada à aplicação de corrente, proporcionou um incremento na resistência ôhmica quando comparado ao concreto de referência e ao concreto carbonatado, conforme se observa nos resultados de EIE através dos diagramas de Nyquist e Bode. No entanto, o concreto carbonatado submetido à RAQ ou à RAE não apresentou profundidade de realcalinização significativa quando medida através da aspersão de fenolftaleína. Portanto, é provável que a utilização da solução alcalina de hidróxido de cálcio não tenha alterado o $\mathrm{pH}$, conforme apresentado nos resultados de profundidade de realcalinização através da fenolftaleína, e sim tenha contribuído para uma maior colmatação dos poros com a sua carbonatação. Provavelmente, isto, explica a razão do aumento da resistência ôhmica quando comparado ao concreto carbonatado.

Porém, ressalta-se que a utilização do hidróxido de cálcio possibilitou a realcalinização da região ao redor da barra.

Conforme descrito anteriormente, os resultados dos ensaios de absorção por capilaridade e de ascensão capilar não corroboraram para análise da condição do concreto, pois os resultados obtidos mostram que a taxa de absorção de água não sofrem qualquer incremento em relação ao concreto antes da carbonatação (referência), o que é incongruente com o levantamento bibliográfico do fenômeno. 


\subsubsection{DURABILIDADE DA REALCALINIZAÇÃO QUÍMICA}

Os ensaios de carbonatação dos corpos-de-prova não carbonatados (referência) e a recarbonatação dos realcalinizados quimicamente com as soluções de carbonato de sódio e hidróxido de potássio, proporcionaram resultados significativos para a avaliação da RAQ. A recarbonatação não foi realizada nos corpos-de-prova submetidos a RAQ utilizando a solução de hidróxido de cálcio em razão deste ensaio ter sido realizado apenas nos corpos-de-prova sem armadura. E, conforme descrito nos resultados de realcalinização utilizando esta solução, nos corpos-de-prova sem armadura não se observou nenhuma profundidade de realcalinização por meio da aplicação da fenolftaleína. Ou seja, os corpos-de-prova sem armadura se apresentavam completamente carbonatados mesmo após a utilização da RAQ com solução de hidróxido de cálcio. A realcalinização do concreto utilizando a solução alcalina de hidróxido de cálcio, tanto na RAQ quanto na RAE, foi observada apenas nos corpos-deprova com barras e, especificamente, na região ao redor da barra. Isto indica, que, possivelmente, ocorra uma maior fixação do hidróxido de cálcio nesta região em razão de sua interação com barra, seja esta interação induzida pela aplicação de corrente na RAE ou pela absorção da solução alcalina na RAQ.

Os corpos-de-prova de referência já mostravam um grande avanço na profundidade de carbonatação depois de 15 dias na câmara de carbonatação acelerada. Já os corpos-de-prova realcalinizados não apresentavam qualquer vestígio de recarbonatação. Aos 45 dias de ensaio acelerado de carbonatação, a frente de carbonatação já havia atingido quase que a totalidade de todo o concreto dos corpos-deprova de referência não carbonatados. Enquanto os corpos-de-prova realcalinizados com as soluções de carbonato de sódio e hidróxido de potássio se mantinham intactos.

Os produtos formados após a finalização do tratamento, conforme discutido anteriormente, têm a capacidade de promover o refino dos poros no interior do concreto. Portanto, o bom desempenho dos concretos realcalinizados pode ser atribuído a maior dificuldade de penetração do $\mathrm{CO}_{2}$ e de difusão do gás no interior do concreto após o tratamento com a RAQ. 


\subsubsection{CONSIDERAÇÕES FINAIS}

Muitas vezes é possível resolver o problema da carbonatação do concreto armado ainda em uma fase precoce, o que reduziria os custos de intervenção e garantiria a eficácia da técnica, prolongando a vida útil das estruturas.

Desta forma, sugere-se que a realcalinização eletroquímica, assim como a química, seja mais utilizada em caráter preventivo quando a carbonatação se encontra apenas no cobrimento, sem atingir a armadura.

As técnicas de realcalinização possuem a vantagem de não necessitar a remoção do concreto carbonatado. No qual, geralmente, apenas a camada de concreto destacada, mal aderida, com defeitos de concretagem ou degradada é que necessita ser retirada e reparada antes do início do tratamento.

Porém, com base nos resultados obtidos, a eficácia da técnica em relação à repassivação das armaduras pode ser comprometida em estágios avançados de corrosão, ou seja, em uma situação de propagação, e não iniciação, da corrosão.

A solução de hidróxido de cálcio, apesar dos ótimos resultados obtidos em relação à repassivação das armaduras com os tratamentos de RAE e RAQ, não propicia a realcalinização do cobrimento do concreto, devendo então ser melhor estudada e, até que sua eficácia seja melhor entendida, sua aplicação deve ser vista com ressalvas.

A solução de carbonato de sódio conseguiu proporcionar bons resultados de potencial de corrosão quando utilizada na RAE e na RAQ. No ensaio de EIE, a RAE com a solução de carbonato de sódio conseguiu aumentar a resistência ôhmica do concreto (faixa de alta freqüência dos diagramas de Bode) quando comparado com os resultados de referência (concreto antes da carbonatação). Na região de baixa frequiência dos diagramas de Bode, a solução alcalina de carbonato de sódio proporcionou um acréscimo da resistência elétrica da armadura, característica de uma barra em estado de passivação. Na RAQ, o ensaio de EIE mostrou que a solução alcalina de carbonato de sódio não se mostrou tão eficiente quanto na RAE. Os diagramas de Bode da RAQ mostraram uma armadura com resistência ôhmica e ângulo de fase com valores muito abaixo dos obtidos com a armadura passivada do concreto de referência (antes da carbonatação).

A solução de hidróxido de potássio utilizada no tratamento de RAE e RAQ, assim como a solução de carbonato de sódio, se mostrou eficiente em relação à condição de repassivação da armadura, através do ensaio de medida de potencial de 
corrosão. Os resultados de EIE, com os tratamentos de RAE e RAQ, mostraram um concreto (região de baixa freqüência) com resistência ôhmica e valores de ângulo de fase menor do que no concreto de referência (antes da carbonatação), provavelmente decorrente dos novos produtos formados com a realcalinização. Os resultados de EIE obtidos na região de alta freqüência mostram que as barras submetidas aos tratamentos de RAE e RAQ apresentaram uma resistência elétrica bem acentuada e com valores próximos aos obtidos antes da carbonatação.

A técnica de realcalinização química vem se mostrando a cada estudo uma possibilidade real de técnica de reparo. $\mathrm{O}$ avanço no seu conhecimento proporcionará benefícios significativos na diminuição dos custos atualmente praticados nos reparos tradicionais em estruturas de concreto com corrosão da armadura por carbonatação, além da diminuição de entulhos, poeiras e barulhos gerados.

\subsection{Sugestão Para Trabalhos Futuros}

- Avaliação da eficiência das realcalinizações eletroquímica e química em função do grau de corrosão das armaduras.

- Verificação da eficiência da repassivação em função de diferentes tipos de soluções alcalinas quando submetido o concreto a um novo ciclo de carbonatação.

- Comparação da influência da reação álcali-agregado em concretos de referência, carbonatados e realcalinizados

- Estudo da influência da RAA em concretos realcalinizados com diferentes soluções alcalinas.

- Estudo da microestrutura do concreto realcalinizado.

- Analisar o efeito da solução alcalina de $\mathrm{KOH}$ em concretos não carbonatados e compará-lo com os efeitos depois do concreto realcalinizado com esta solução alcalina.

- Ensaios de ultrassom em concretos realcalinizados quimicamente.

- Avaliação dos compostos formados no cobrimento e ao redor da armadura após a realização da realcalinização com solução saturada de $\mathrm{Ca}(\mathrm{OH})_{2}$. 


\section{REFERÊNCIA BIBLIOGRÁFICA}

ABNT - ASSOCIAÇÃO BRASILEIRA DE NORMAS TÉCNICAS. NBR5739. Concreto - Ensaio de compressão de corpos-de-prova cilíndricos. Método de Ensaio. Rio de Janeiro, 2007. Janeiro, 2003.

NBR 6118. Projeto de estruturas de concreto - Procedimento. Rio de NBR7211. Agregado para concreto. Especificação. Rio de Janeiro, 1983.

NBR7215. Cimento Portland - Determinação da resistência à compressão. Método de Ensaio. Rio de Janeiro, 1996.

NBR9778. Argamassa e concreto endurecidos - Determinação da absorção de água, índice vazios e massa específica. Método de Ensaio. Rio de Janeiro, 2005.

NBR9779. Argamassa e concreto endurecidos - Determinação da absorção de água por capilaridade. Método de Ensaio. Rio de Janeiro, 1995. 1991.

NBR11578. Cimento Portland composto. Especificação. Rio de Janeiro,

ABREU, A.G. Estudo da corrosão da armadura induzida por carbonatação em concretos com cinza volante. 2004. 169p. Tese (Doutorado) - Programa de PósGraduação em Engenharia Civil, Universidade Federal do Rio Grande do Sul, Porto Alegre.

ACI - AMERICAN CONCRETE INSTITUTE. Protection of metals in concrete against corrosion. Reported by ACI Committee 222. 2001. 41p.

. Proposed revision of: Guide to durable concrete. Reported by ACI Committee 301. 1991. 43p.

ANDRADE, C. Manual para diagnóstico da obras deterioradas por corrosão de armaduras. Tradução e adaptação de Antônio Carmona e Paulo Helene. $1^{a}$ edição. São Paulo: Ed. PINI, 1992. 104p.

ANDRADE, C.; ALONSO, C.; SARRÍA, J.; RÍO, O. Técnicas de reparación de estructuras dañadas por corrosión de armaduras. In: CONPAT 97 - IV Congresso Iberoamericano de Patologias das Construções e VI Congresso de Controle de Qualidade. Porto Alegre, Brasil, 1997. Anais, vol. 1, p. 47-54.

ANDRADE, C.; CASTELlOTE, M.; SARRIA, J.; ALONSO, C. Evolution of pore solution chemistry, electro-osmosis and rebar corrosion rate induced by realkalisation. Materials and Structures, vol. 32, July, 1999, p. 427-436. 
ANDRADE, C.; MERINO, P.; NÓVOA, X.R.; PÉREZ, M.C.; SOLER, L. Passivation of reinforcing steel in concrete. Materials Science Forum, vol. 192-194, 1995, p. 891898.

AOKI, I.V. Disciplina: PQI5760 - Corrosão e Processos de Proteção em Materiais Metálicos (Apostila de aula). $3^{\circ}$ Quadrimestre de 2008. Universidade de São Paulo USP. São Paulo, Brasil.

ARAUJO, F.W.C. Contribuição à viabilização da técnica de realcalinização do concreto carbonatado através da absorção/difusão de soluções alcalinas. 2004. 157p. Dissertação (Mestrado) - Curso de Mestrado em Engenharia Civil, Universidade Federal de Goiás, Goiânia.

ARAUJO, F.W.C.; FIGUEIREDO, E.J.P. Realkalisation of the carbonated concrete. In: IV International ACI/CANMET - Conference on Quality of Concrete Structures and Recent Advances in Concrete Materials andTesting. Olinda, Brazil, 2005. Proceedings, p.19-32.

ARAUJO, F.W.C.; FIGUEIREDO, E.J.P.; AGUIAR Jr., H.O.; CARVALHO, M.A.S. Contribuição para a viabilização da técnica de realcalinização do concreto carbonatado: efeito na aderência de argamassas industrializadas. In: VIII Congresso Latinoamericano de Patologia de la Construcción - X Congresso de Control de Calidad en la Construcción - CONPAT, Asunción, Paraguay, 2005. CD-ROM.

ARAUJO, F.W.C.; FIGUEIREDO, E.P.; HELENE, P. Contribuição para a viabilização da técnica de realcalinização do concreto carbonatado: repassivação da armadura. In. 49 $9^{\circ}$ CONGRESSO BRASILEIRO DO CONCRETO - CBC2007. Bento Gonçalves, Brasil, 2007a. CD-ROM.

ARAUJO, F.W.C.; HELENE, P. Realcalinização eletroquímica: técnica preventiva ou de reabilitação? Revista Concreto e Construção, Ed. IBRACON, n. 50, Abr. Mai. Jun. São Paulo, Brasil, 2008.

ARAUJO, F.W.C.; PAZINI FIGUEIREDO, E.; SÁ, R.R.; HELENE, P. Efeitos da aderência de argamassas industrializadas, tintas e vernizes em substratos realcalinizados. In. Congresso Construção 2007 - 3. ${ }^{\circ}$ Congresso Nacional, 17 a 19 de Dezembro, Coimbra, Portugal, Universidade de Coimbra, 2007c. CD-ROM.

ARAUJO, F.W.C.; PAZINI FIGUEIREDO, E.; SÁ, R.R.; HELENE, P. Efeitos da aderência de argamassas industrializadas, tintas e vernizes em substratos realcalinizados. Revista Internacional Construlink, edição n. 18, vol. 7. Lisboa, Portugal, 2009.

ARAUJO, F.W.C.; PAZINI FIGUEIREDO, E.; SÁ, R.R.; HELENE, P. Realcalinização do concreto carbonatado: reconstituição da película de passivação. In. IX Congresso Latinoamericano de Patologia de la Construcción - XI Congresso de Control de Calidad en la Construcción - CONPAT, Quito, Equador, 2007b. CD-ROM.

ASTM - AMERICAN SOCIETY FOR TESTING AND MATERIALS. Standard test method for half-cell potential of uncoated reinforcing steel in concrete - C876. In: Annual Book of ASTM Standards. 1991. Philadelphia. 
Standard recommended practice for maintaining constant relative humidity by means of aqueous solutions - E104. In: Annual Book of ASTM Standards. 2002. Philadelphia.

Standard practice for preparing, cleaning, and evaluating corrosion test specimens - G1. In: Annual Book of ASTM Standards. 2003. Philadelphia.

BANFILL, P. F. G. Features of the mechanism of re-alkalisation and desalinization treatments for reinforced concrete. In: International Conference on Corrosion and Corrosion Protection of Steel in Concrete. University of Sheffield, 1994. Anais, p. 1489-1498.

Re-alkalisation of reinforced concrete: present problems and future possibilities. Concrete Repair, Rehabilitation and Protection. Ed. E \& FN Spon, 1996, p. 473-482.

Re-alkalisation of carbonated concrete: effect on concrete properties. Construction and Building Materials, Elsevier, n 11, 1997, p. 255 - 258.

BASSET, J.; DENNEY, R.C. Análise inorgânica quantitativa VOGEL. $4^{a}$ edição. Rio de Janeiro: Ed. Guanabara, Tradução Aida Espinola. 1981. 690 p.

CASCUDO, O. Contribuição·ao estudo e emprego de técnicas eletroquímicas no controle da corrosão de armaduras em concreto armado. 1991. 230p. Dissertação (Mestrado) - CPGECC, Escola Politécnica de São Paulo - USP, São Paulo.

CASTEllote, M., LlORENTE, I., ANDRADE, C. Electroomótico inducido por realcalinización em función de la concentración de $\mathrm{Na}_{2} \mathrm{CO}_{3}$ em el anolito. In. VII Congresso Latinoamericano de Patologia de la Construcción - IX Congresso de Control de Calidad en la Construcción - CONPAT, Mérida, México, 2003. CD-ROM.

CASTELLOTE, M.; LLORENTE, I.; ANDRADE, C.; TURRILLAS, X.; ALONSO, C.; CAMPO, J. In-situ monitoring the realkalisation process by neutron diffraction: Electroosmotic flux and portlandite formation. Cement and Concrete Research, vol. 36, 2006a, p. $791-800$.

CASTELLOTE, M.; LLORENTE, I.; ANDRADE, C.; TURRILLAS, X.; ALONSO, C.; CAMPO, J. Neutron diffraction as a tool to monitor the establishment of the electroosmotic flux during realkalisation of carbonated concrete. Physica B, vol. 385-386, 2006b, p. 526-528.

CASTRO, A. Influência das adições minerais na durabilidade do concreto sujeito à carbonatação. 2003. 215p. Dissertação (Mestrado) - Curso de Mestrado em Engenharia Civil, Universidade Federal de Goiás, Goiânia.

CEB - COMITE EURO-INTERNACIONAL du BETON. Durability of concrete structures. State of the art report. Bulletin D’Information $n^{\circ} .152,1984$.

CEN - EUROPEAN COMMITTEE FOR STANDARDIZATION. Electrochemical realkalisation and chloride extraction treatments for reinforced concrete - Part 1: Re-alkalisation. EN 14038-1 - Part 1. 2005.8-1 - Part 1. 2005. 
CHANG, C.F.; CHEN, J.W. The experimental investigation of concrete carbonation depth. Cement and Concrete Research, vol. 36, p. 1760- 1767, 2006.

DELAHAY, P. The precursor of the International Society of Electrochemistry. Electrochemica Acta, vol. 45, 2000, p. xxv-xxiv.

DIEZ-PEREZ, I.; SANZ, F.; GOROSTIZA, P. In situ studies of metal passive films. Current Opinion in Solid State and Materials Science, vol. 10, 2006, p 144-152.

EGGERS, M.; OLIVEIRA, P.S.F. Novas técnicas eletroquímicas de recuperação de estruturas de concreto: realcalinização e dessalinização (extração de cloretos). In: IV Congresso Iberoamericano de Patologia das Construções. Porto Alegre, Brasil, 1997. Anais, p. 215-222.

FERREIRA, M.G.S.; SIMÕES, A.M.P. Passivation and localized corrosion. In. Electrochemical and Optical Techniques for the Study and Monitoring of Metallic Corrosion. Kluwer Academic Publishers. Netherlands, 1991, p.485-520.

FIGUEIREDO, E.J.P. Avaliação do desempenho de revestimentos para proteção da armadura contra a corrosão através de técnicas eletroquímicas: contribuição ao estudo de reparo de estruturas de concreto armado. 1994. 423p. Tese (Doutorado) CPGECC, Escola Politécnica de São Paulo - USP, São Paulo.

As técnicas eletroquímicas e o estudo da durabilidade do concreto armado. In: Seminário Internacional dos Avanços na Tecnologia do Concreto. Goiânia, 1999. Anais, p. 44-57.

FIGUEIREDO, E.J.P.; ANDRADE, C.; HELENE, P.R.L. Fatores determinantes da iniciação e propagação da corrosão da armadura de concreto. São Paulo, Departamento de Engenharia de Construção Civil - PCC, Escola Politécnica da Universidade de São Paulo - EPUSP, 1993. (Boletim técnico da Escola Politécnica da USP. Departamento de Engenharia de Construção Civil, BT/PCC121).

FIGUEIREDO, E.J.P.; ARAUJO, F.W.C.; TEIXEIRA, F.A. Realcalinização do concreto carbonatado através da penetração de solução alcalina. In. XXXI Jornadas Sud-Americanas de Ingeniería Estructural. Mendonza, Argentina, 2004. CD-ROM.

FLIS, J.; ZAKROCZYMSKI, T. Impedance Study of Reinforcing Steel in Simulated Pore Solution with Tannin. Journal Electrochemical Society, vol. 143, August, 1996, p. 2458-2464.

FOSROC. Compatibility of coatings applied over realkalised and desalinated concrete. Fosroc International Limited, sd. 12p.

GALVÃO, S.P.; CASCUDO, O. Avaliação do desempenho de argamassas estruturais de reparo com relação à propriedade de aderência em substratos de concreto saturado superfície seca. In. $47^{\circ}$ Congresso Brasileiro do Concreto - CBC2005. Olinda, Brazil, 2007. CD-ROM.

GERVAIS, C.; GARRABRANTS, A.C.; SANCHEZ, F.; BARNA, R.; MOSZKOWICZ, P.; KOSSON, D.S. The effects of carbonation and drying during 
intermittent leaching on the release of inorganic constituents from a cement-based matrix. Cement and Concrete Research, vol. 34, 2004, p. 119-131.

GONÇALVES, A.; ANDRADE, C.; CASTELlOTE, M. Procedimentos de reparo e proteção de armaduras. In: Manual de reparo, prteção e reforço de estruturas de concreto. Red Rahabilitar e Degussa. 2005, Cap. 7, p. 331-366.

GONÇALVES, A.; ANDRADE, C.; CASTELlOTE, M. Procedimientos de reparación de armaduras. In: Manual de rehabilitación de estructuras de hormigón: reparación, refuerzo y protección. CYTED - XV-F. 2003, Cap. 7, p. 338-376.

GONEN, T.; YAZICIOGLU, S. The influence of compaction pores on sorptivity and carbonation of concrete. Construction and Building Materials, vol 21, 2007b, p. $1040-1045$.

GONEN, T.; YAZICIOGLU, S. The influence of mineral admixtures on the short and long-term performance of concrete. Building and Environment, vol. 42, 2007a, p. 3080-3085.

GONZALEZ, J.A.; COBO, A.; GONZALEZ, M.N.; OTERO, E. On the effectiveness of realkalisation as a rehabilitation method for corroded reinforced concrete structures. Materials and Corrosion, vol. 51, 2000, p. 97-103.

GU, P.; BEAUDOIN, J.J.; ZHANG, M.H.; MALHOTRA, V.M. Performance of steel reinforcement in Portland cement and high-volume fly ash concretes exposed to chloride solution. ACI Materials Journal, nº. 96, September-October, 1999, p. 551559.

GU, P.; ELLIOTT, S.; HRISTOVA, R.; BEAUDOIN, J.J.; BROUSSEAU, R.; BALDOCK, B. A study of corrosion inhibitor performance in chloride contaminated concrete by electrochemical impedance spectroscopy. ACI Materials Journal, $\mathrm{n}^{\circ}$. 94, September-October, 1997, p. 385-395.

HABOUBI, L. Extending the boundaries of concrete repair: an electrochemical approach to cost effective durability. Fosroc Internacional (ME), October, 2000.

HELENE, P.R.L. Corrosão em armaduras de concreto armado. $1^{a}$ edição. São Paulo: Ed. PINI, 1986. 46p.

Contribuição ao estudo da corrosão em armaduras de concreto armado. 1993, 231p. Tese (Livre-Docência) - Departamento de Engenharia de Construção Civil, Escola Politécnica de São Paulo - USP, São Paulo.

Vida útil das estruturas. Téchne, $n^{\circ} .17$, julho/agosto, 1995, p. 28-31.

Rehabilitación y mantenimiento de estructuras de concreto. In. Rehabilitación y mantenimiento de estructuras de concreto. $1^{a}$ edição, São Paulo, Brasil. 2007. Introducción, p. 17-32

HELENE, P.; TERZIAN, P. Manual de dosagem e controle do concreto. São Paulo, Ed. Pini, 1995. 349p. 
ISAIA, G.C.; GASTALDINI, A.L.G. Critical analysis on HPC with very high contents of mineral additions (Part I). IBRACON Materials Journal, vol. 2, September, 2006, p. 09-19.

ISLAM, M.; DAILY, S.F. Use of electrochemical techniques to assess performance of corrosion protection systems for reinforced concrete structures-A review. Journal of ASTM International, February, vol. 3, nº. 2, 2006, p. 1-12.

JIANG, L.; LINB, B.; CAI, Y. A model for predicting carbonation of high-volume fly ash concrete. Cement and Concrete Research, vol. 30, 2000, p. 699-702.

JOHANNESSON, B.; UTGANANNT, P. Microstructural changes caused by carbonatiion of cement mortar. Cement Concrete Research, vol. 31, 2001, p. 925-931.

KAZMIERCZAK, C.S., Contribuição para análise de eficiência de películas aplicadas sobre estruturas de concreto armado com o objetivo de proteção contra a carbonatação. 1995. 168p. Tese (Doutorado) - CPGECC, Escola Politécnica de São Paulo - USP, São Paulo.

KENNEDY, D.; MILLER, J.B.; NUSTAD, G.E. Review of chloride extraction and re-alkalisation of reinforced concrete. NTC, Paper n. 53, 1995. 17p.

KIRCHHEIM, A.P. Concreto de cimento portland branco estrutural: avaliação da carbonatação e absorção capilar. 2003. 169p. Dissertação (Mestrado) - Programa de Pós-Graduação em Engenharia Civil, Universidade Federal do Rio Grande do Sul, Porto Alegre.

KULAKOWSKI, M.P. Contribuição ao estudo da carbonatação em concretos e argamassas compostos com adição de sílica ativa. 2002. 180 p. Tese (Doutorado) Programa de Pós-Graduação em Engenharia de Minas, Metarlugia e de Materiais, Universidade Federal do Rio Grande do Sul, Porto Alegre.

LARA, P.L.O. Análise da relação entre propriedades de transporte de água e os mecanismos de corrosão das armaduras. 2003. 108p. Dissertação (Mestrado) - Curso de Mestrado em Estruturas e Construção Civil, Universidade de Brasília, Brasília.

LO, Y.; LEE; H.M. Curing efects on carbonation of concrete using a phenolphthalein indicator and Fourier-transform infrared spectroscopy. Building and Environment, vol. 37, 2002, p. $507-514$.

MACHADO, M.A.G.T.C. Inibidores de corrosão em concreto armado contra o ataque de agentes da chuva ácida. 2004. 161p. Tese (Doutorado). Universidade Federal de São Carlos, São Carlos, 2004.

MANDENO, W. Electrochemistry to the rescue: NZ War Memorial Refurbishment. Corrosion \& Materials, vol 24. no . 4, August, 1999, p. 6-7.

MATSUMOTO, K.I.; UEDA, T.; ASHIDA, M.; MIYAGAMA, T. Study on realkalization with electrolyte containing lithium ion. International Journal of Modern Physics B, vol. 17, 2003, p. 1446-1451. 
MATTILA, J.S.; PENTTI, M.J. The performance of different realkalisation methods. Concrete Repair, Rehabilitation and Protection. Ed. E \& FN Spon, 1996, p. 483-491.

McGOVERN, M.S. Chloride ion removal and realkalization stop corrosion by restoring a passive environment in reinforced concrete. Current technologies curb rebar corrosion. 1996.

MEDEIROS, M.H.F. Contribuição ao estudo da durabilidade de concretos com proteção superficial frente à ação de íons cloretos. 2008. 140p. Tese (Doutorado) CPGECC, Escola Politécnica de São Paulo - USP, São Paulo.

MEDEIROS, M.H.F. Estruturas de concreto com corrosão de armaduras por carbonatação: comparação de argamassas de reparo quanto à proteção do aço. 2002. 146p. Dissertação (Mestrado) - CPGECC, Escola Politécnica de São Paulo - USP, São Paulo.

MEHTA, P.K; MONTEIRO, P.J.M. Concreto: estrutura, propriedades e materiais. $3^{\mathrm{a}}$ edição. São Paulo, Ed. IBRACON, 2008. 674p.

MIETZ, J. Electrochemical rehabilitation methods for reinforced concrete structures. European Federation of Corrosion Publications, $n^{\circ} .24 .1^{\text {st }}$ edition. England: Ed. IOM communications Ltd, 1998. 57p.

MIETZ, J.; ISECKE, B. Rahabilitation of corrosion induced damage of reinforced concrete structures by electrochemical protection methods. In. Progress in the understanding and prevention of corrosion. Editor J. M. Costa e A. D. Mercer. Published by Institute of Materials - European Federation of Corrosion, vol. 1, 1993, p. 611-618.

Monitoring of concrete structures with respect to rebar corrosion. Construction and Building Materials, vol. 10, $\mathrm{n}^{\circ} .5,1996$, p. 361-313.

MILLER, J.B. Structural aspect of high powered electro-chemical treatment of reinforced concrete. In: International Conference on Corrosion and Corrosion Protection of Steel in Concrete. University of Sheffield, 1994. Anais, p. 1499-1514.

The perception of the ASR problem with particular reference to electrochemical treatments of reinforced concrete. In: EUROCORR 97 - Corrosion of reinforcement in concrete - monitoring, prevention and rehabilitation. Trondheim, Norway, 1998. Anais, p. 141-149.

MIRANDA, J.M.; GONZÁLES, J.A.; OTERO, E.; COBO, A. Consideraciones sobre la repassivación-rehabilitación de las estructuras corroidas de concreto armado. In. VII Congresso Latinoamericano de Patologia de la Construcción - IX Congresso de Control de Calidad en la Construcción - CONPAT, Mérida, México, 2003. CD-ROM.

MIRANDA, J.M.; GONZÁLEZ, J.A.; COBO, A.; OTERO, E. Several questions about electrochemical rehabilitation methods for reinforced concrete structures. Corrosion Science, vol. 48, no . 8, 2006, p. 2172-2188.

MONTEIRO, E.C.B. Avaliação do método de extração eletroquímica de cloretos para reabilitação de estruturas de concreto com problemas de corrosão das 
armaduras. 2002. 211p. Tese (Doutorado) - CPGECC, Escola Politécnica de São Paulo - USP, São Paulo.

MORENO, M.; MORRIS, W.; ALVAREZ, M.G.; DUFFO, G.S. Corrosion of reinforcing steel in simulated concrete pore solutions. Effect of carbonation and chloride content. Corrosion Science, vol. 46, 2004, p. 2681-2699.

NCT - NORWEGIAN CONCRETE TECHNOLOGIES. NORCURE ${ }^{\text {TM }}$ Desalination and realkalisation: mechanisms and advantages. NCT, 1996.

ODDEN, L. The repassivating effect of electro - chemical realkalisation end chloride extraction. In: International Conference on Corrosion and Corrosion Protection of Steel in Concrete. University of Sheffield, 1994. Anais, p. 1473-1488.

PAGE, C.L.; YU, S.W. Potential effects of electrochemical desalination of concrete on alkali-silica reaction. Magazine of Concrete Research, v. 47. $n^{\circ}$. 170, march, 1995, p. 23-32.

PAPADAKIS, V.G. Effect of supplementary cementing materials on concrete resistance against carbonation and chloride ingress. Cement and Concrete Research, vol. 30, 2000, p. 291-299.

PAULETTI, C. Análise comparativa de procedimentos para ensaios acelerados de carbonatação. 2004. 162p. Dissertação (Mestrado) - Programa de Pós-Graduação em Engenharia Civil, Universidade Federal do Rio Grande do Sul, Porto Alegre.

PAULETTI, C.; DAL MOLIN, D.C.C.; KAZMIERCZAK, C.S. Análise comparativa de diferentes percentuais de $\mathrm{CO}_{2}$ em ensaios acelerados de carbonatação. Revista IBRACON de Materiais-RIMAT, vol. 3, nº. 1, March, p. 63-72, 2007.

PAZINI, E.; CASTRO, P.; HELENE, P. Sistemas de reparación para estructuras dañadas por corrosión. In. Corrosión en estructuras de concreto armado: teoría, inspección, diagnóstico, vida útil y reparaciones. $1^{a}$ edición. México: Ed. Instituto Mexicano Del Cemento u Del Concreto, A.C, 1998. Capitulo 9, p. 93-116.

PEREIRA, M.F. Mudança estratégica em uma organização hospitalar: um estudo de caso dos últimos 20 anos. 1996. Dissertação (Mestrado) - Programa de Pós-Graduação em Engenharia de Produção, Universidade Federal de Santa Catarina, Florianópolis (site: http://www.eps.ufsc.br/disserta96/mauricio/index).

POURSAEE, A.; HANSSON, C.M. Reinforcing steel passivation in mortar and pore solution. Cement and Concrete Research, vol. 37, 2007, p. 1127-1133.

RHA, C.Y.; KIM, W.S.; KIM, J.W.; PARK, H.H. Relationship between microstructure and electrochemical characteristics in steel corrosion. Applied Surface Science, vol. 169-170, p. 587-592, 2001.

RILEM. Measurement of hardened concrete carbonation depth. RILEM CPC-18 Recommendation. Materials and Structures Journal, vol. 21, p. 453-455, 1988.

Permeability of concrete as a criterion of its durability: Part C. Determination of the capillary absorption of water of hardened concrete. RILEM 
TC 116-PCD Final Report - Part C. Materials and Structures Journal, vol. 32, p. 176$178,1999$.

Electrochemical techniques for measuring metallic corrosion. RILEM TC 154-EMC Recommendation. Materials and Structures Journal, vol. 37, p. 623-643, 2004.

ROY, S.K.; POHB, K.B.; NORTHWOODC, D.O. Durability of concrete-accelerated carbonation and weathering studies. Building and Environment, vol. 23, 1999, p. 486595

SÁ, R.R. Influência da realcalinização por meio da absorção/difusão de soluções alcalinas na resistência à compressão do concreto, na aderência de tintas e vernizes e na repassivação da armadura. 2006. 154p. Dissertação (Mestrado) - Curso de Mestrado em Engenharia Civil, Universidade Federal de Goiás, Goiânia.

SAETTA A.V.; VITALIANI, R.V. Investigation and numerical modeling of carbonation process in reinforced concrete structures. Part I: Theorical formulation. Cement and Concrete Research, v. 34, n. 4, Apr 2004, p. 571-579.

SANJUÁN, M.A.; OLMO, C. Carbonation resistance of one industrial mortar used as a concrete coating. Building and Environment, vol. 36, 2001, p. 949-953.

SILVA, F.G. Estudo de concretos de alto desempenho frente à ação de cloretos. 2006. 220p. Tese (Doutorado). Interunidades em Ciência e Engenharia dos Materiais da Universidade de São Paulo - USP, São Paulo.

SILVA, V.C. Realcalinização e dessalinização do betão deteriorado: tratamento em vez de cirurgia. Associação Técnica da Indústria do Cimento - ATI, nº 19, novembro, 1996, p. 23-27.

SITTER, W.R. Costs for Service Life Optimization. The "law of fives". In: CEBRILEM Durability of concrete structures. Proceedings of the International Workshop held in Copenhagem on 18-20 May 1983. (workshop reported by Steen Rostam)

SONG, G. Equivalent circuit model for AC electrochemical impedance spectroscopy of concrete. Cement and Concrete Research, vol. 30, 2000, p. 1723-1730.

SONG, H.W.; KWON, S.J. Permeability characteristics of carbonated concrete considering capillary pore structure. Cement and Concrete Research, vol 37, 2007, p. 909-915.

SULLIVAN-GREEN, L.; HIME, W.; DOWDING, C. Accelerated protocol for measurement of carbonation through a crack surface. Cement and Concrete Research, vol. 37, 2007, p. 916-923.

TAYLOR, H.F.W. Cement chemistry. Ed. London: Thomas Telford. 1997. 459p.

TEIXEIRA, F.A. Realcalinização do concreto carbonatado empregando solução rica em álcalis. 2002. 150p. Dissertação (Mestrado) - Curso de Mestrado em Engenharia Civil, Universidade Federal de Goiás, Goiânia. 
THIERY, M.; VILLAIN, G.; Dangla, P.; PLATRET, G. Investigation of the carbonation front shape on cementitious materials: Effects of the chemical kinetics. Cement and Concrete Research, vol. 37, 2007, p. 1047-1058.

TONG, Y.Y.; BOUTEILLER, V.; MARIE-VICTOIRE, E.; JOIRET, S. Durability evaluation of a realkalisation treatment using impressed current. In. 11 International Conference on Durability of Building Materials and Components - DBMC, Istanbul, Turkey, 2008. CD-ROM.

VAGHETTI, M.A.O. Carbonatação e ph dos concretos com adições minerais em relação à corrosão das armaduras. In. $48^{\circ}$ Congresso Brasileiro do Concreto, Rio de Janeiro, Brasil, 2006. CD-ROM.

VAN GERVEN, T.; BAELEN, D. V.; DUTRÉ, V.; VANDECASTEELE, C. Influence of carbonation and carbonation methods on leaching of metals from mortars. Cement and Concrete Research, vol. 34, 2004, p. 149-156.

VELIVASAKIS, E.E.; HENRIKSEN, S.K.; WHITMORE, D. Chloride extraction and realkalisation of reinforced concrete stop steel corrosion. Journal of Perfomance of Constructed Facilities, May, 1998, p. 77-84.

VILLAIN, G.; THIERY, M.; PLATRET, G. Measurement methods of carbonation profiles in concrete: Thermogravimetry, chemical analysis and gammadensimetry. Cement and Concrete Research, vol. 37, 2007, p. 1182-1192.

WHITMORE, D.; ABBOTT, S.; VELIVASAKIS, E. Battling concrete corrosion. Civil Engineering, vol. 69, 1999, p. 46-49.

WOLYNEC, S. Técnicas eletroquímicas em corrosão. Editora da Universidade de São Paulo-EDUSP. 2003. 166p.

YEIH, W.; CHANG, J.J. A study on the efficiency of electrochemical realkalisation of carbonated concrete. Construction and Building Materials, vol. 19, 2005, p. 516-524. 


\section{APÊNDICE A - Resultados de EIE}

Neste apêndice constam os resultados de Espectroscopia de Impedância Eletroquímica (EIE) de todas as barras ensaiadas nesta pesquisa.

\section{RESUltados DE EIE: CORPOS-DE-PROVA ANTES DA CARBONATAÇÃO, CARBONATADOS E REALCALINIZADOS PELA RAE}

\section{$\underline{\text { RELAÇÃO A/C 0,65 COM CURA DE } 1 \text { DIA }}$}

RAE: com solução alcalina de carbonato de sódio a $1 \mathrm{M}\left(\mathrm{Na}_{2} \mathrm{CO}_{3}\right)$
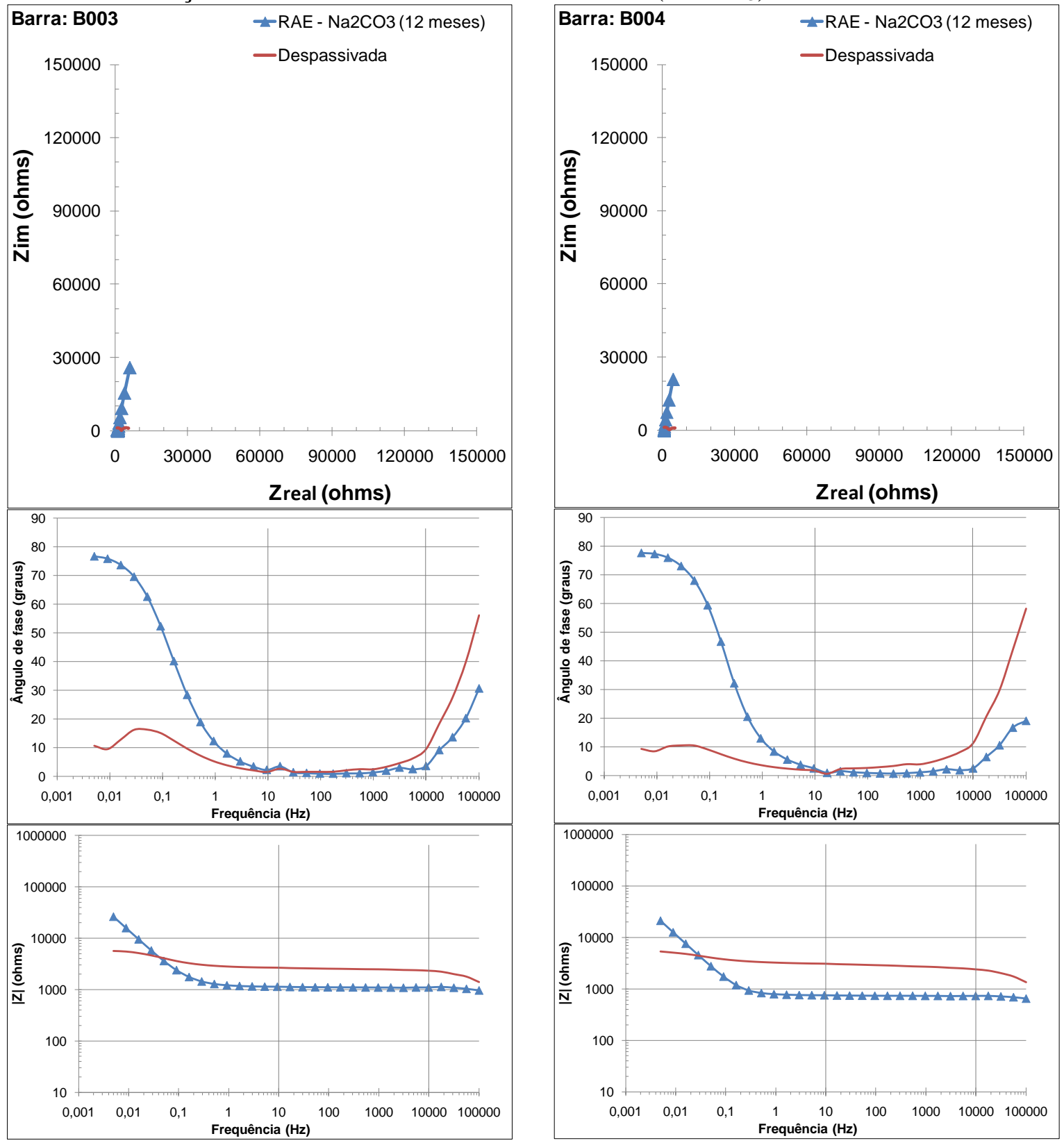


\section{$\underline{\text { RELAÇÃO A/C 0,65 COM CURA DE } 1 \text { DIA }}$}

RAE: com solução alcalina de carbonato de sódio a $1 \mathrm{M}\left(\mathrm{Na}_{2} \mathrm{CO}_{3}\right)$
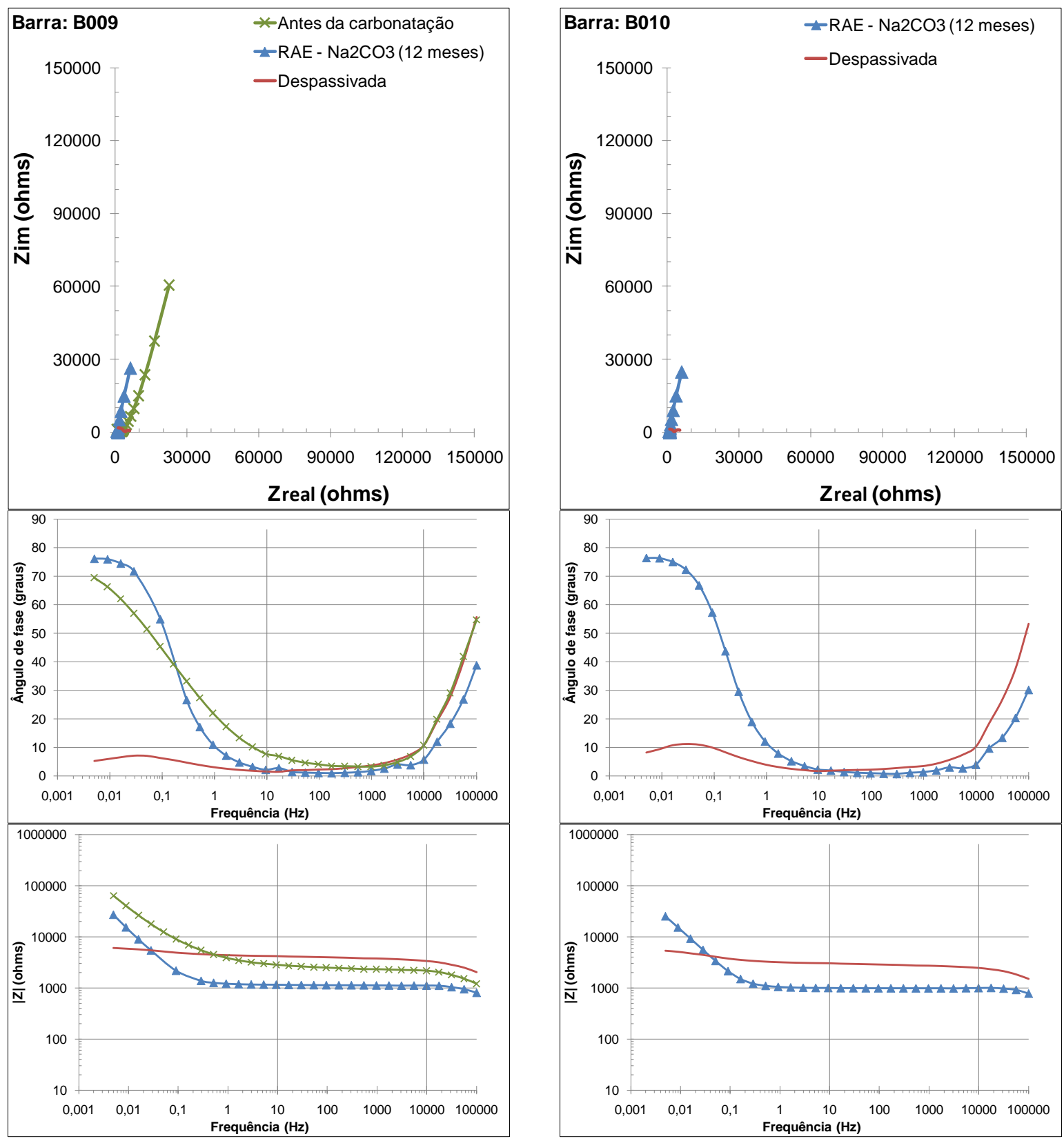


\section{$\underline{\text { RELAČ̃̃O A/C 0,65 COM CURA DE } 1 \text { DIA }}$}

RAE: com solução alcalina de hidróxido de potássio a 2M (KOH)
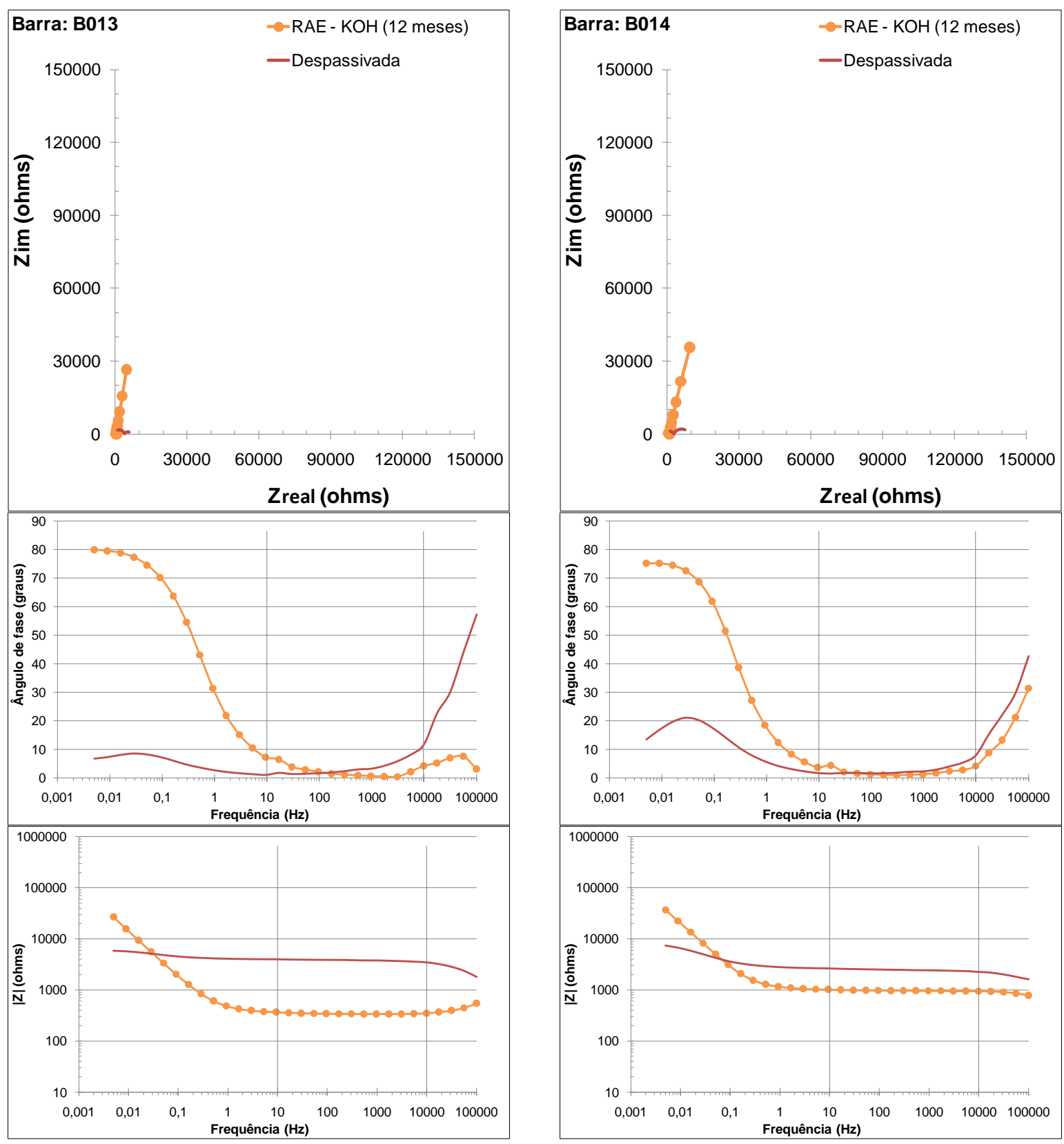


\section{$\underline{\text { RELAČ̃̃O A/C 0,65 COM CURA DE } 1 \text { DIA }}$}

RAE: com solução alcalina de hidróxido de potássio a 2M (KOH)
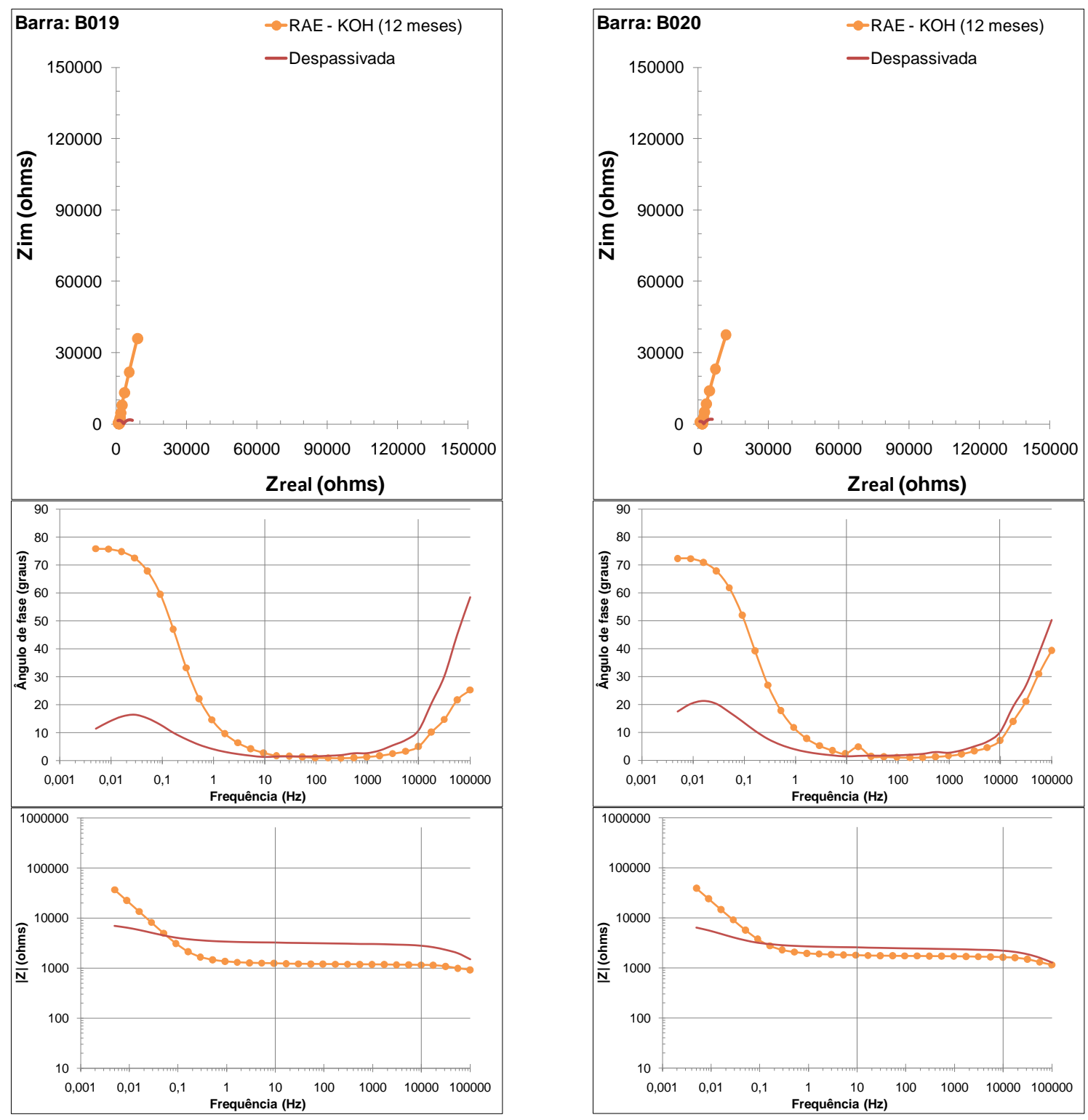
$\underline{\text { RELAÇÃO A/C 0,65 COM CURA DE } 1 \text { DIA }}$

RAE: com solução alcalina de hidróxido de cálcio saturado $\left(\mathrm{Ca}(\mathrm{OH})_{2}\right)$
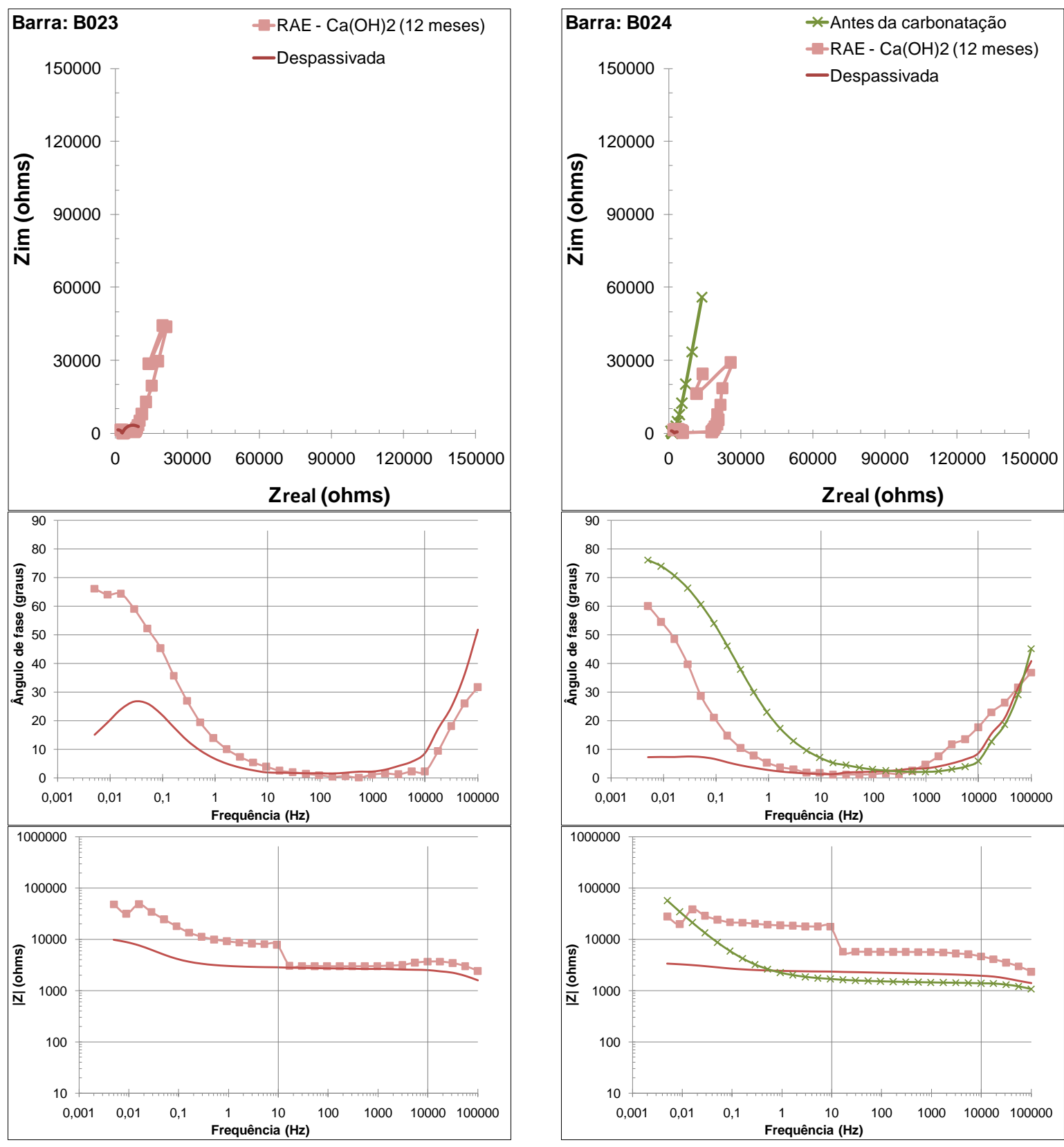
$\underline{\text { RELAÇÃO A/C 0,65 COM CURA DE } 1 \text { DIA }}$

RAE: com solução alcalina de hidróxido de cálcio saturado $\left(\mathrm{Ca}(\mathrm{OH})_{2}\right)$
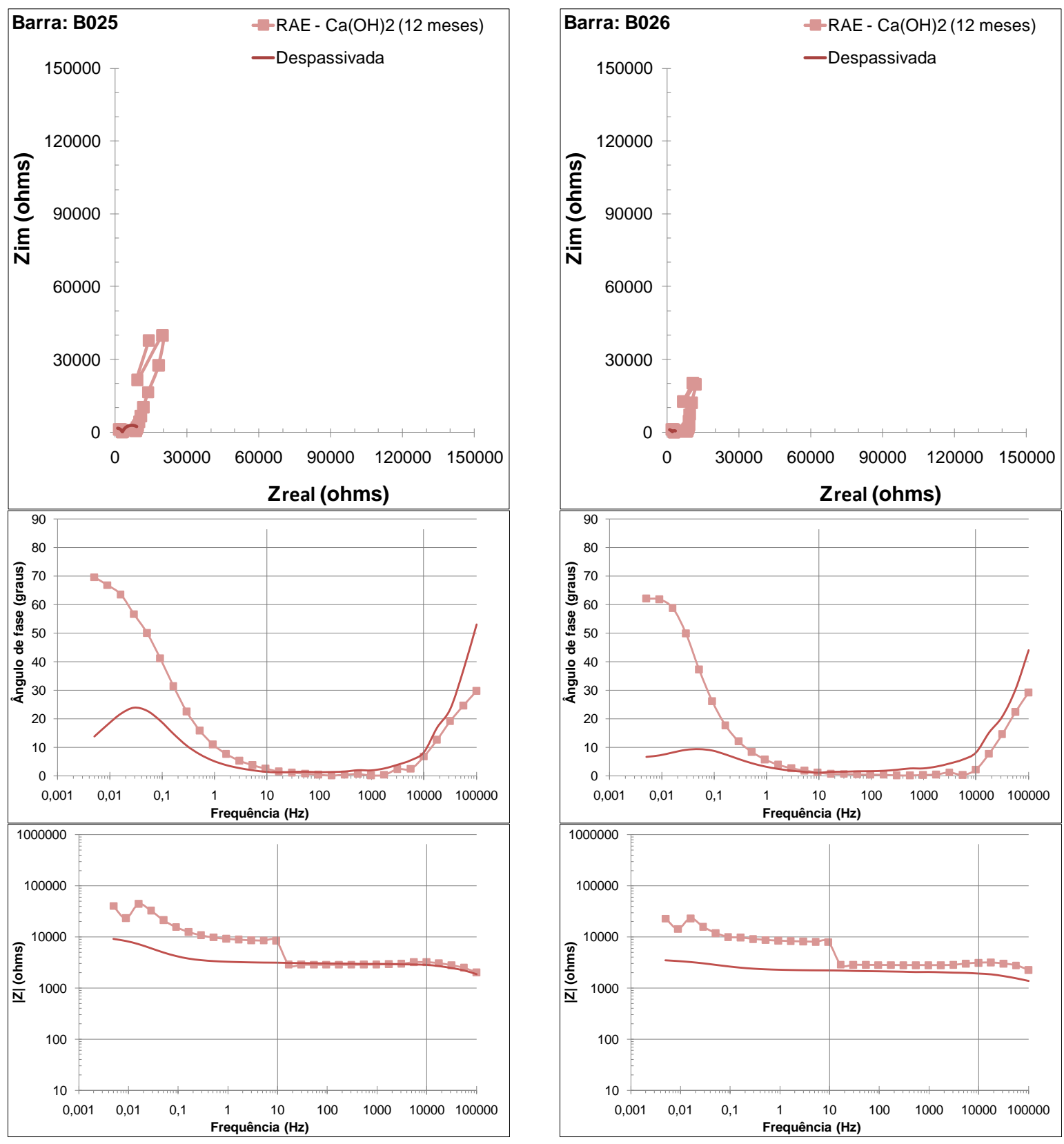


\section{$\underline{\text { RELAÇÃO A/C 0,65 COM CURA DE } 28 \text { DIAS }}$}

RAE: com solução alcalina de carbonato de sódio a $1 \mathrm{M}\left(\mathrm{Na}_{2} \mathrm{CO}_{3}\right)$
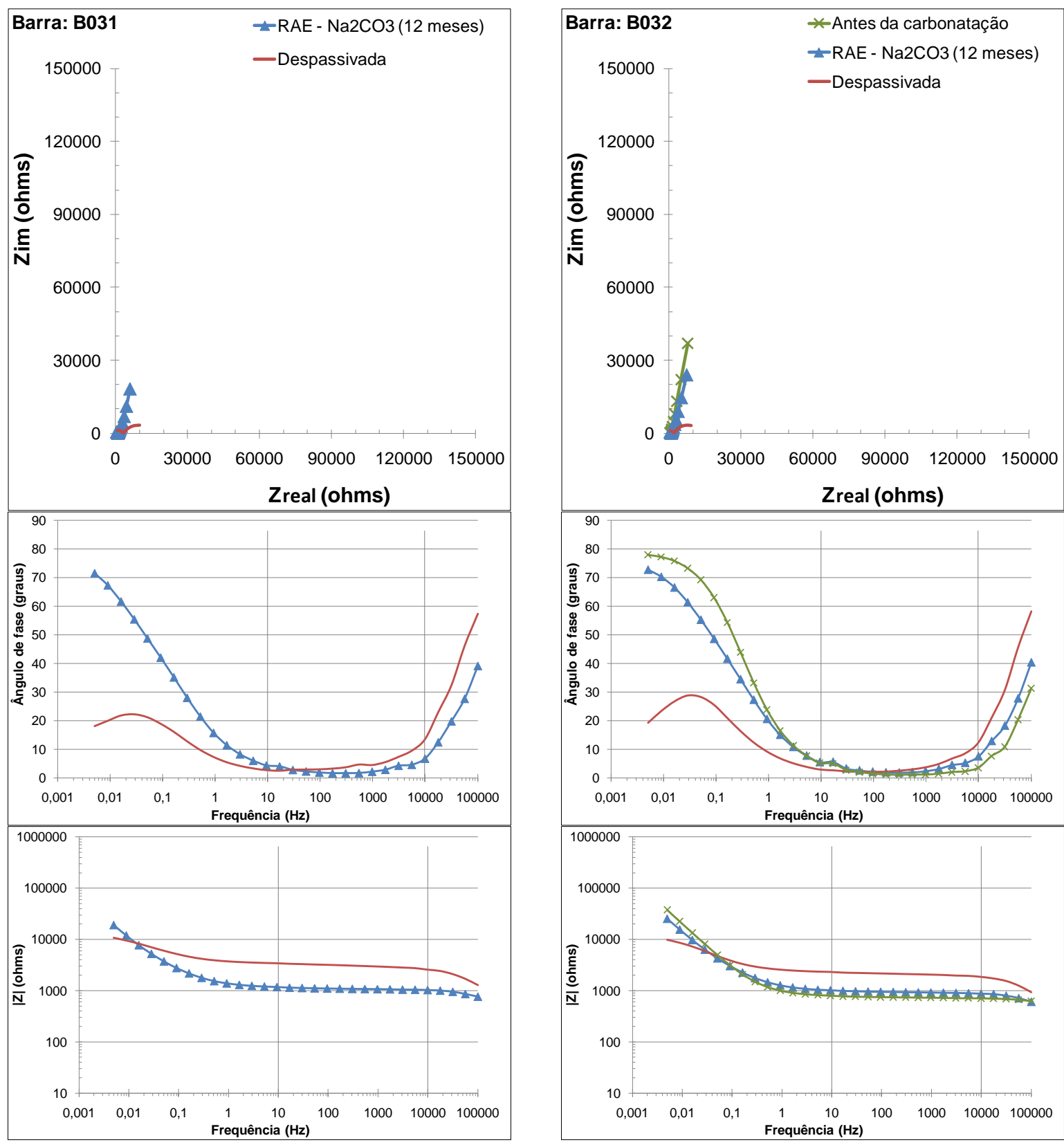
$\underline{\text { RELAČ̃̃O A/C 0,65 COM CURA DE } 28 \text { DIAS }}$

RAE: com solução alcalina de carbonato de sódio a $1 \mathrm{M}\left(\mathrm{Na}_{2} \mathrm{CO}_{3}\right)$
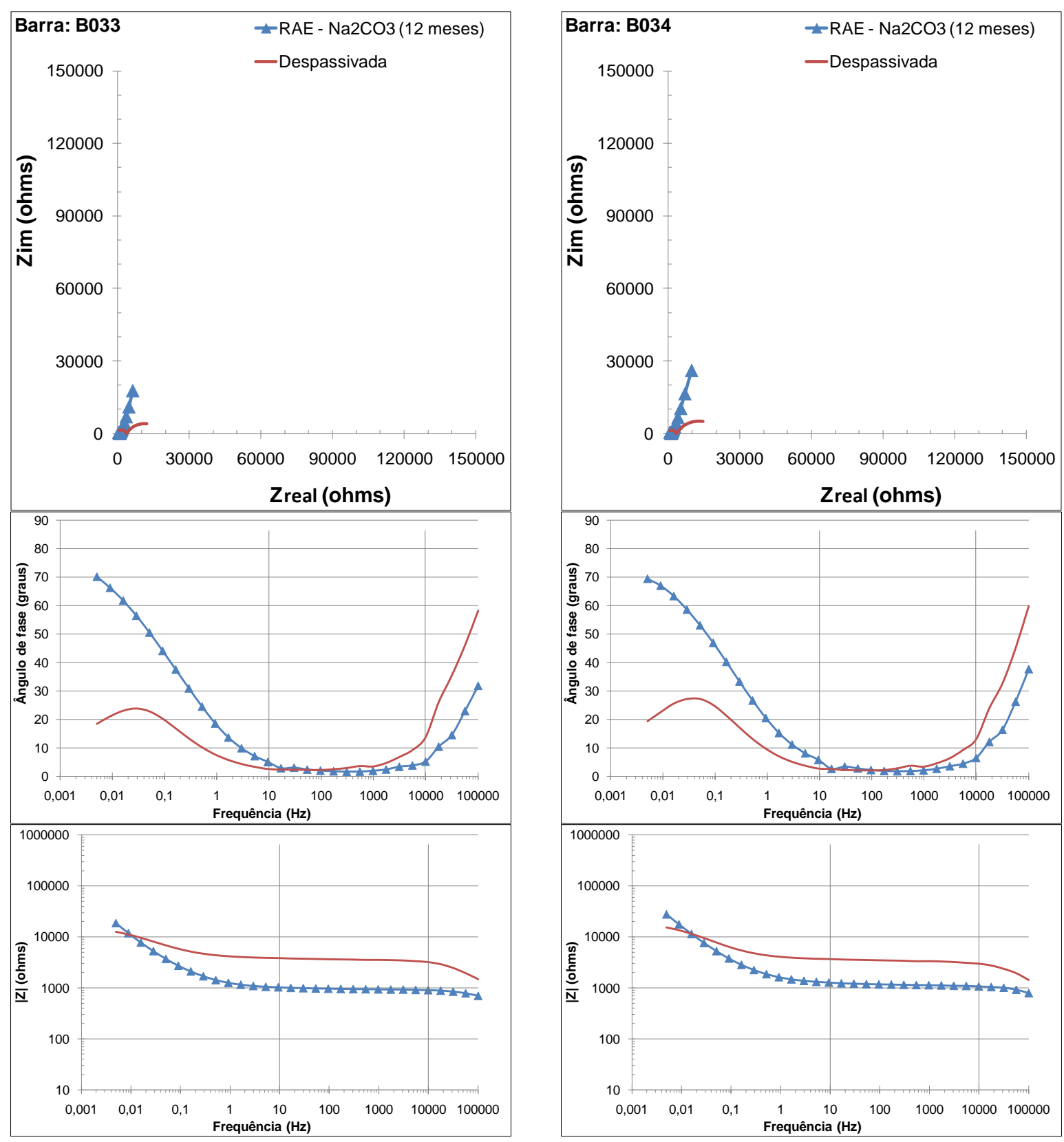


\section{$\underline{\text { RELAÇÃO A/C 0,65 COM CURA DE } 28 \text { DIAS }}$}

RAE: com solução alcalina de hidróxido de potássio a 2M (KOH)
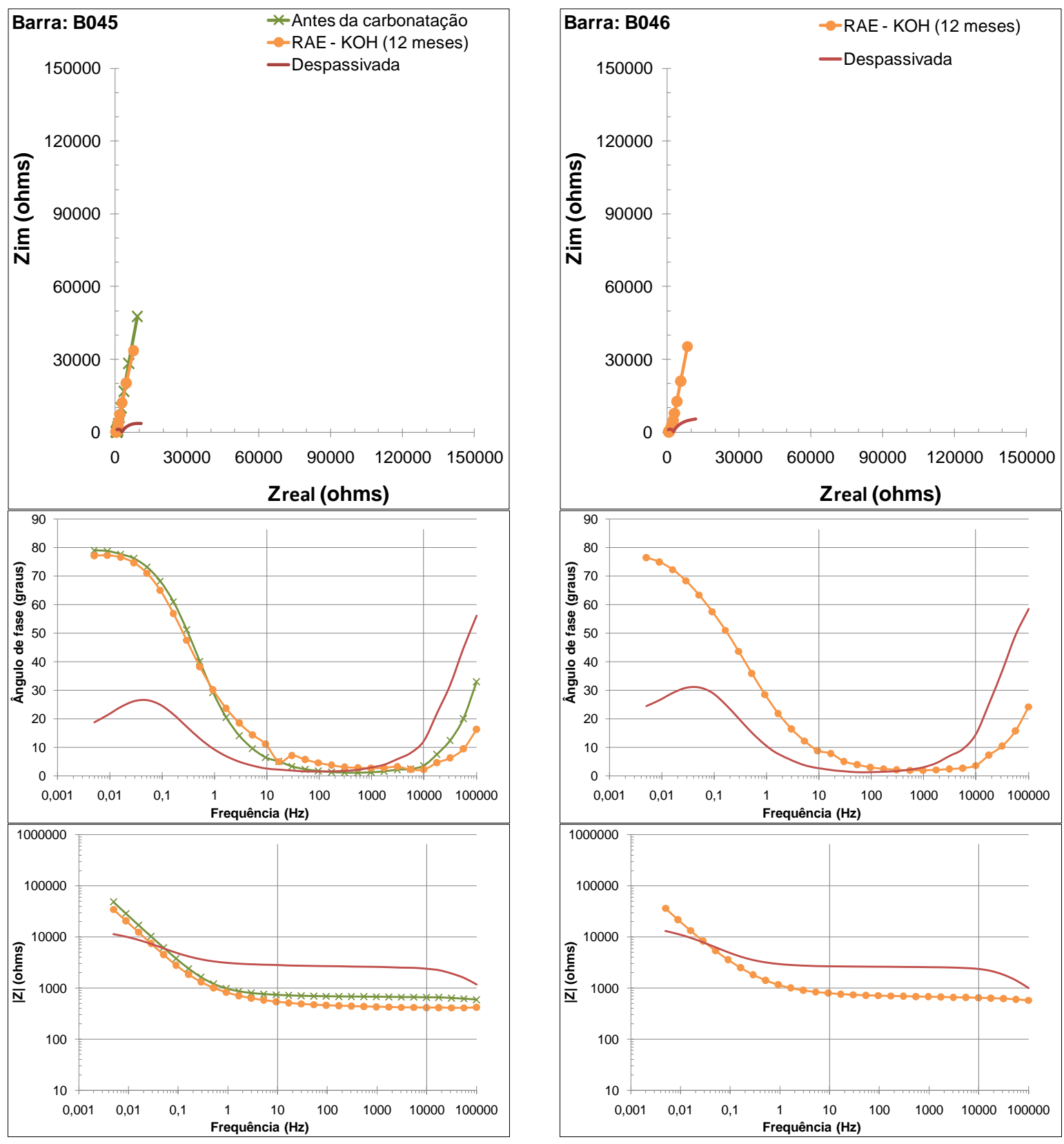


\section{$\underline{\text { RELAÇÃO A/C 0,65 COM CURA DE } 28 \text { DIAS }}$}

RAE: com solução alcalina de hidróxido de potássio a 2M (KOH)
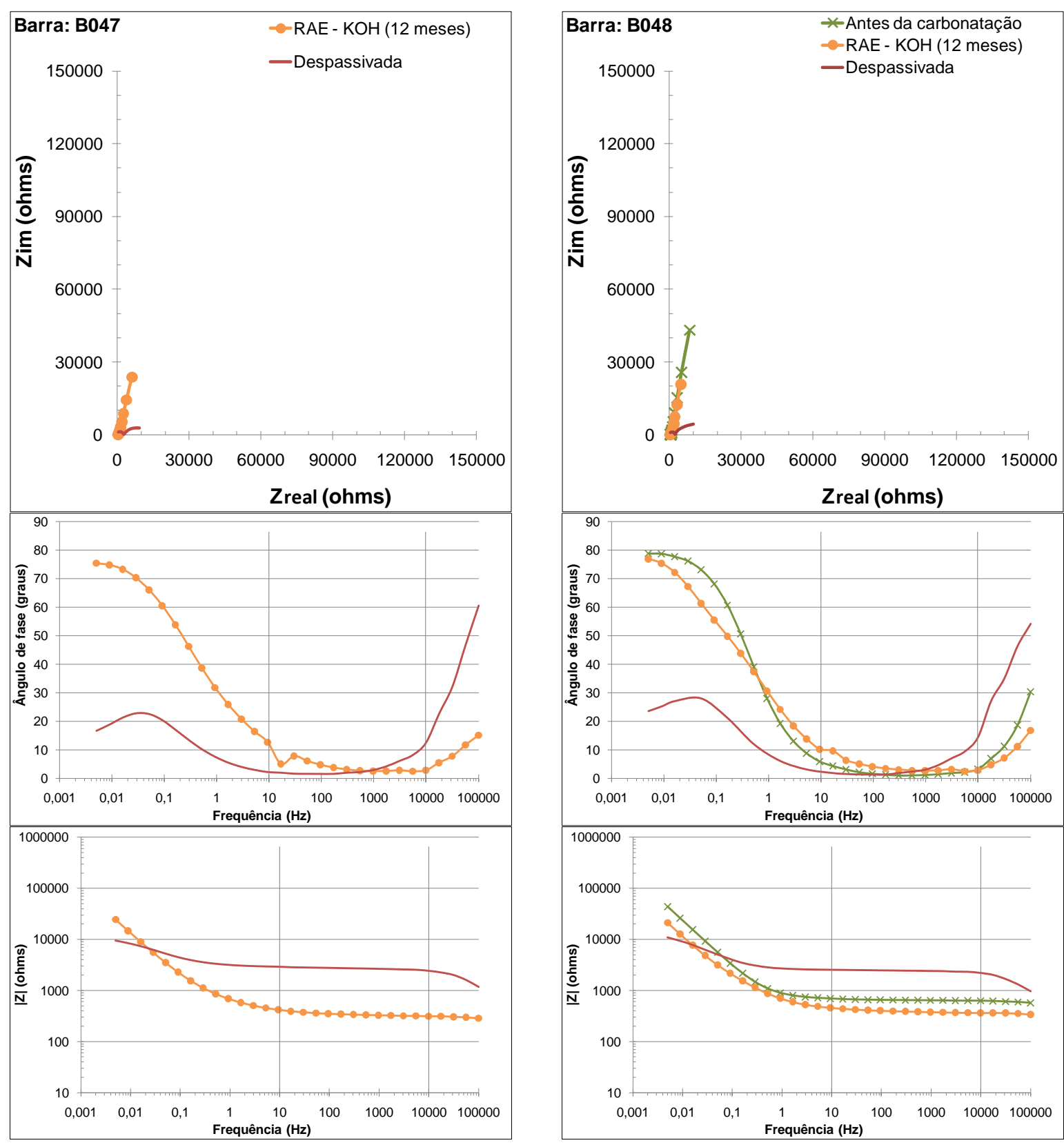
$\underline{\text { RELAÇÃO A/C 0,65 COM CURA DE } 28 \text { DIAS }}$

RAE: com solução alcalina de hidróxido de cálcio saturado $\left(\mathrm{Ca}(\mathrm{OH})_{2}\right)$
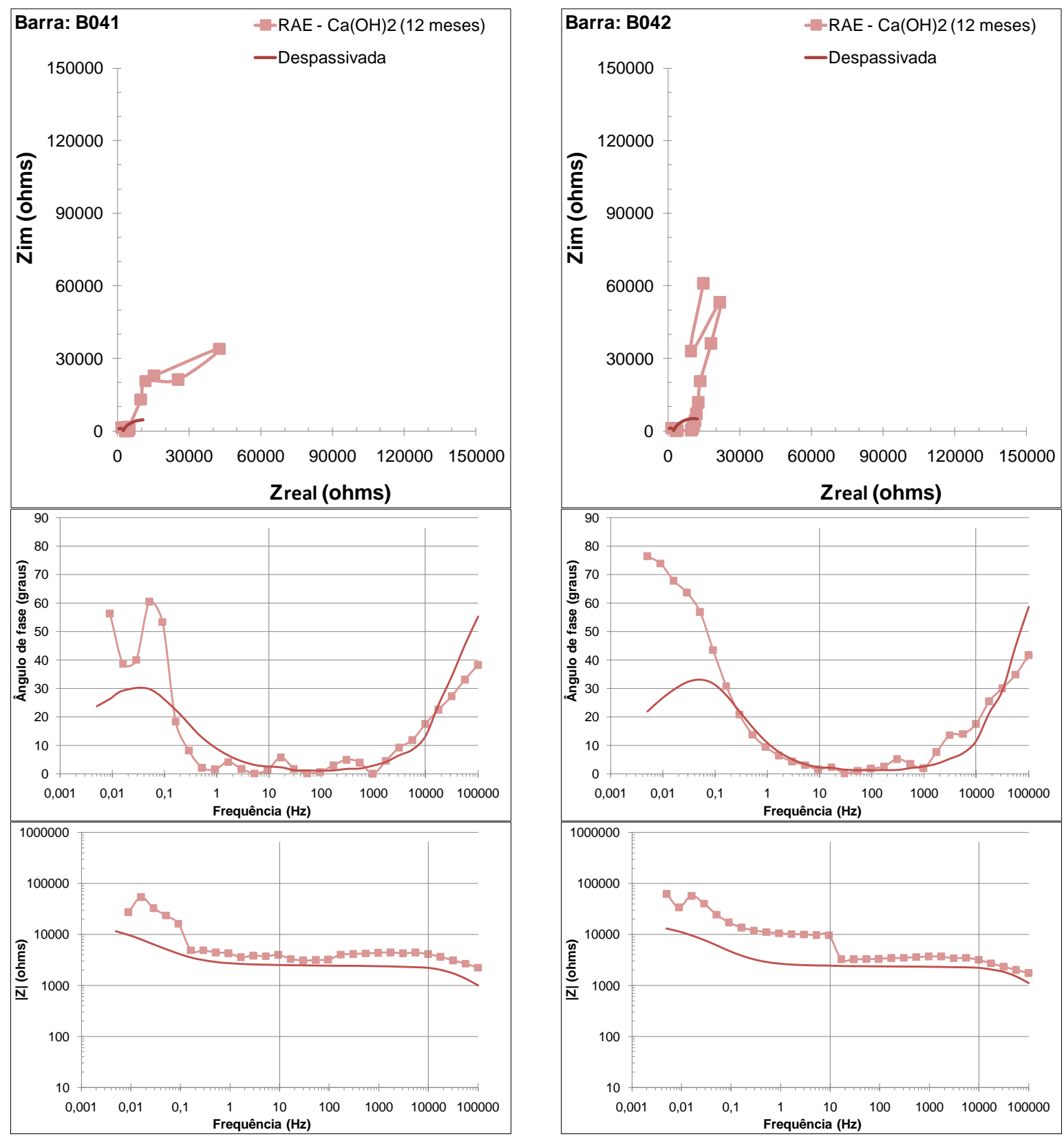
$\underline{\text { RELAÇÃO A/C 0,65 COM CURA DE } 28 \text { DIAS }}$

RAE: com solução alcalina de hidróxido de cálcio saturado $\left(\mathrm{Ca}(\mathrm{OH})_{2}\right)$
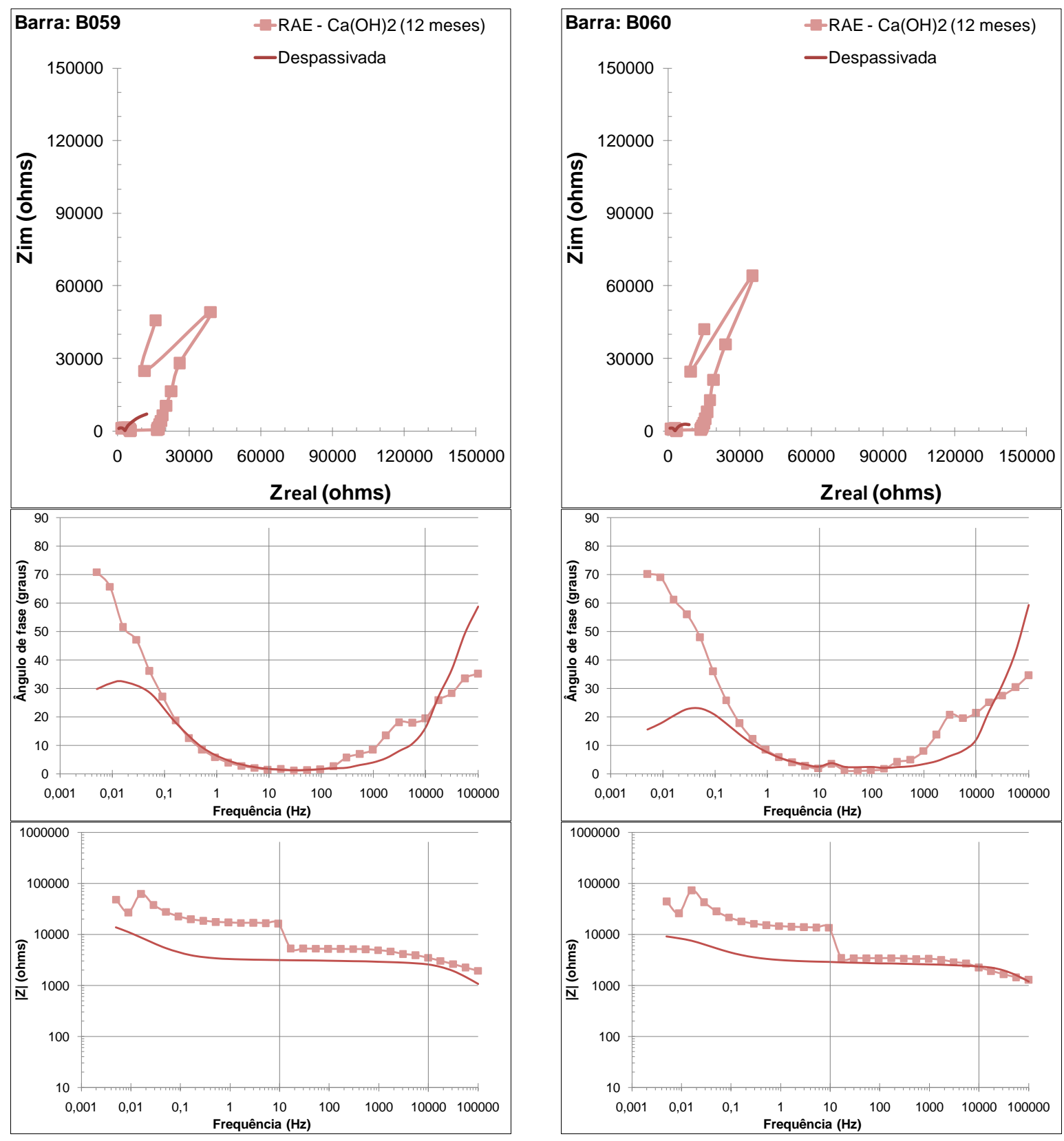
$\underline{\text { RELAÇÃO A/C 0,80 COM CURA DE } 1 \text { DIA }}$

RAE: com solução alcalina de carbonato de sódio a $1 \mathrm{M}\left(\mathrm{Na}_{2} \mathrm{CO}_{3}\right)$
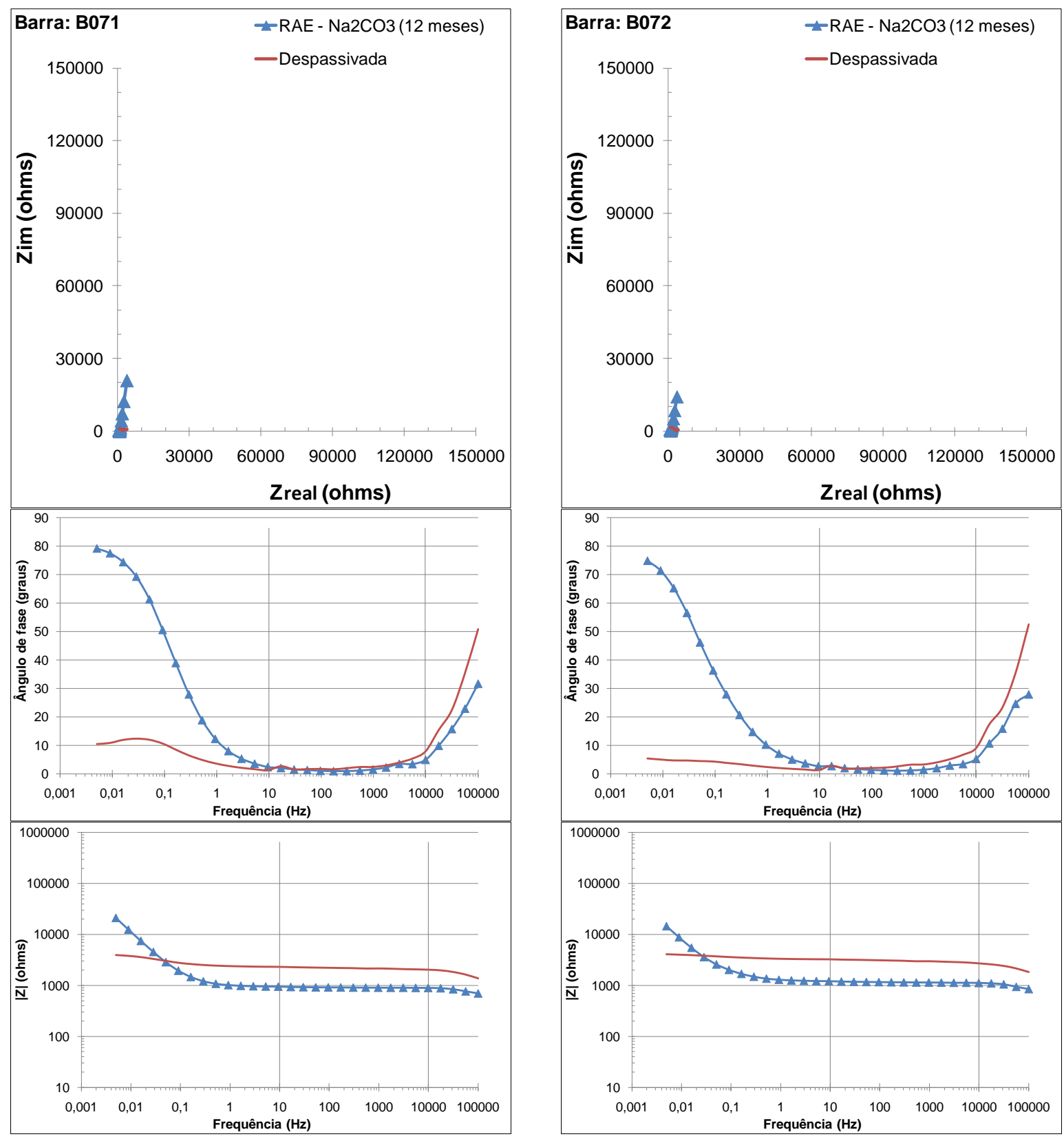
$\underline{\text { RELAÇÃO A/C 0,80 COM CURA DE } 1 \text { DIA }}$

RAE: com solução alcalina de carbonato de sódio a $1 \mathrm{M}\left(\mathrm{Na}_{2} \mathrm{CO}_{3}\right)$
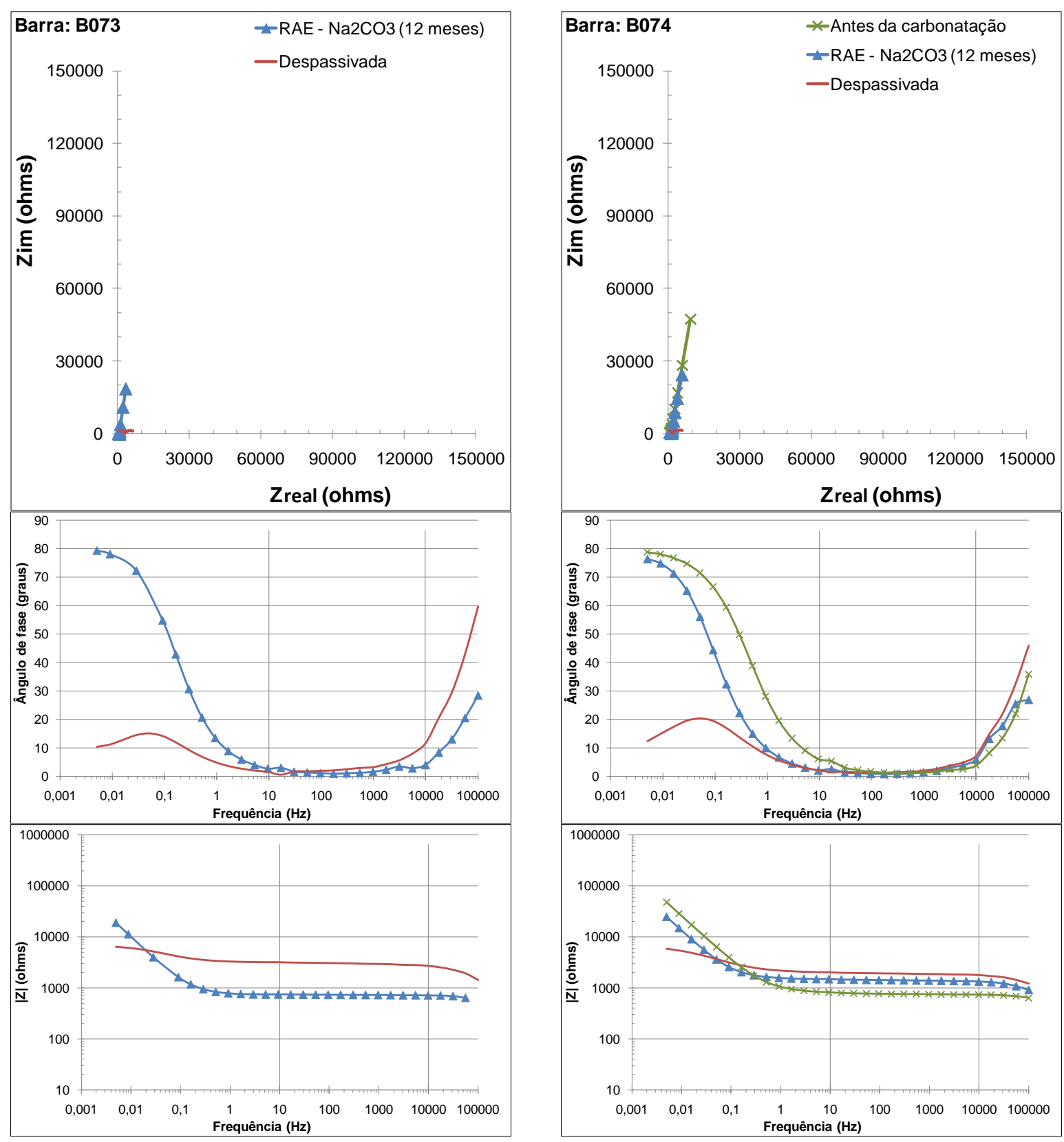
$\underline{\text { RELAÇÃO A/C 0,80 COM CURA DE } 1 \text { DIA }}$

RAE: com solução alcalina de hidróxido de potássio a 2M (KOH)
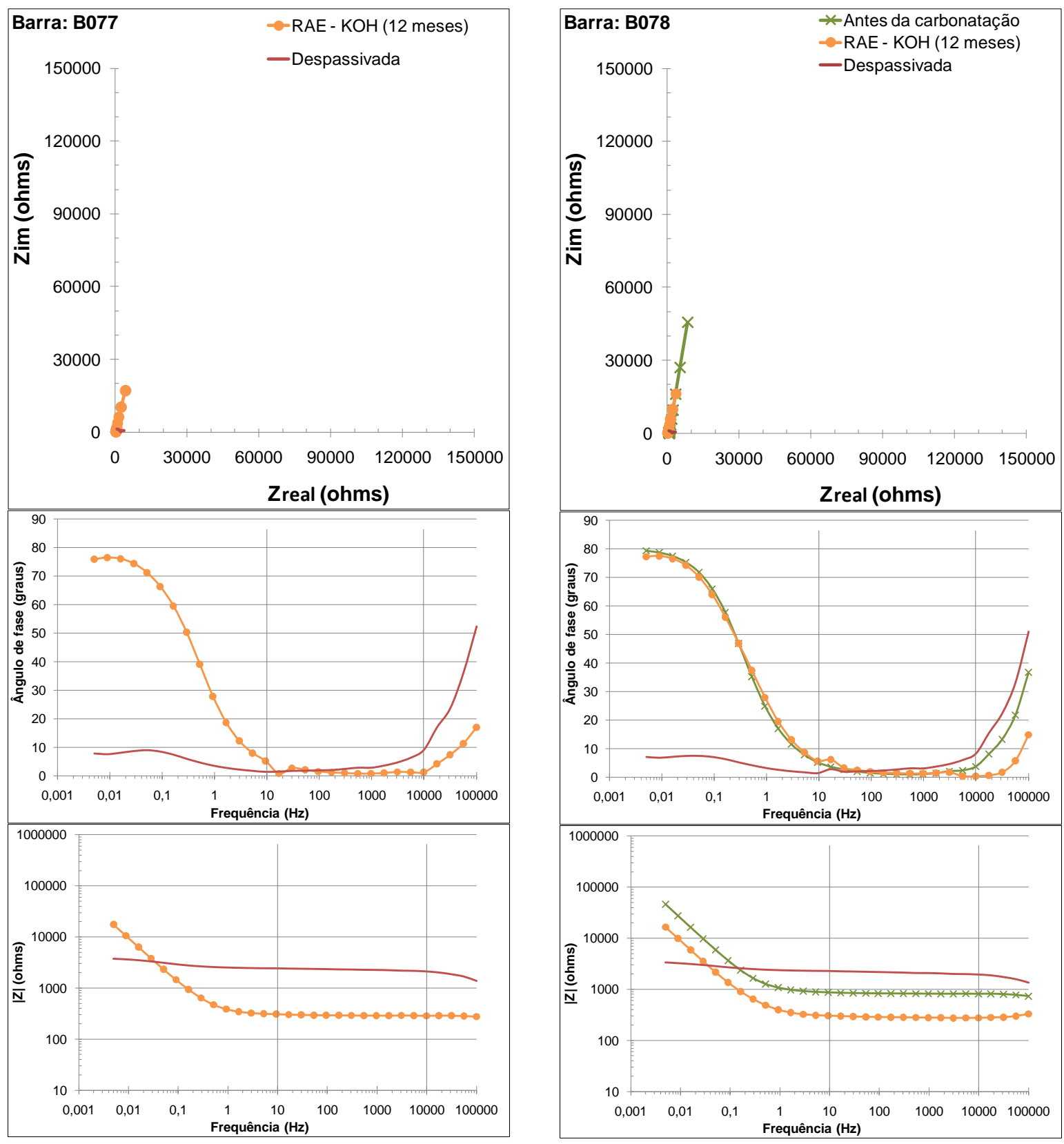
$\underline{\text { RELAÇÃO A/C 0,80 COM CURA DE } 1 \text { DIA }}$

RAE: com solução alcalina de hidróxido de potássio a 2M (KOH)
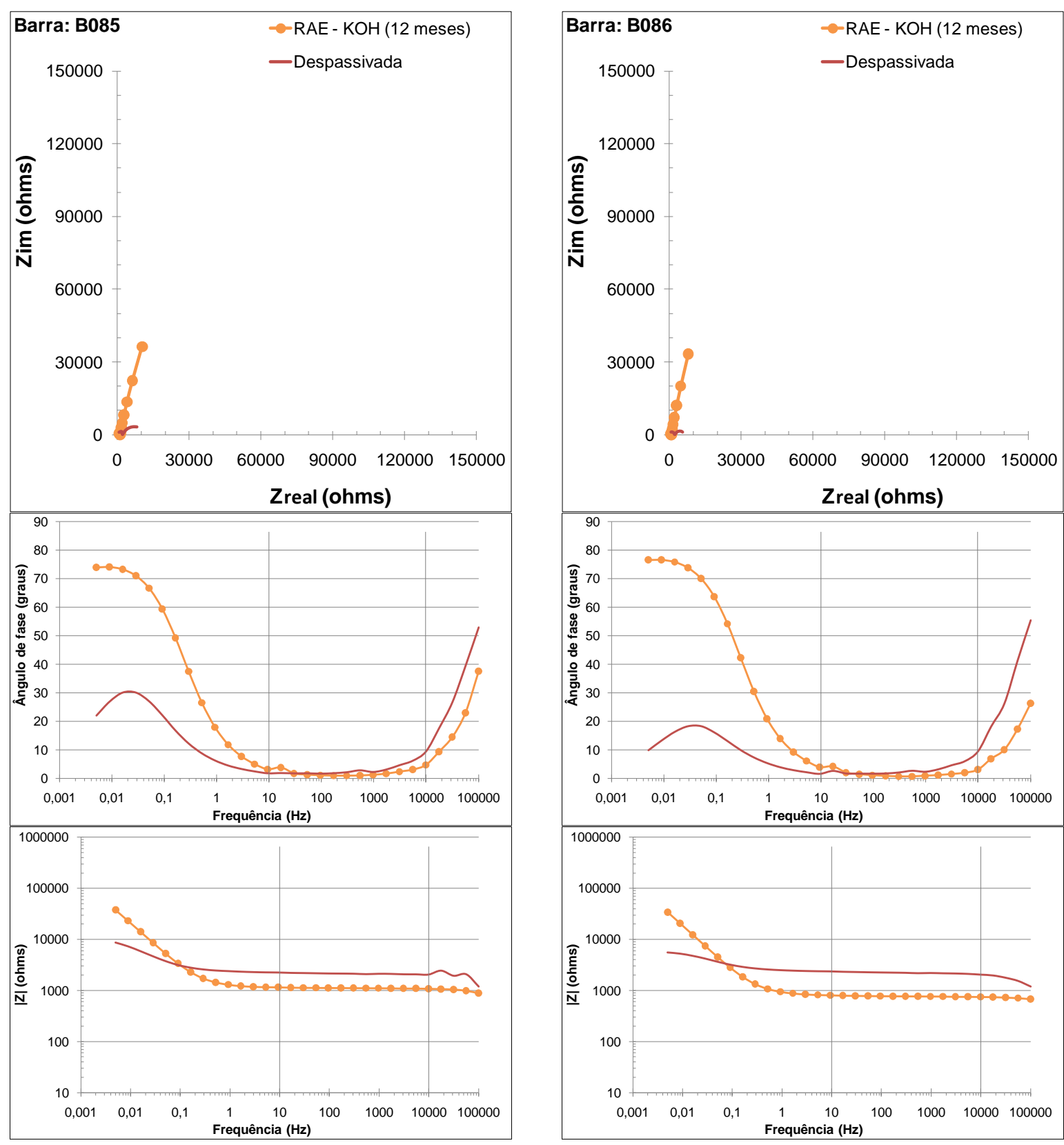
$\underline{\text { RELAÇÃO A/C 0,80 COM CURA DE } 1 \text { DIA }}$

RAE: com solução alcalina de hidróxido de cálcio saturado $\left(\mathrm{Ca}(\mathrm{OH})_{2}\right)$
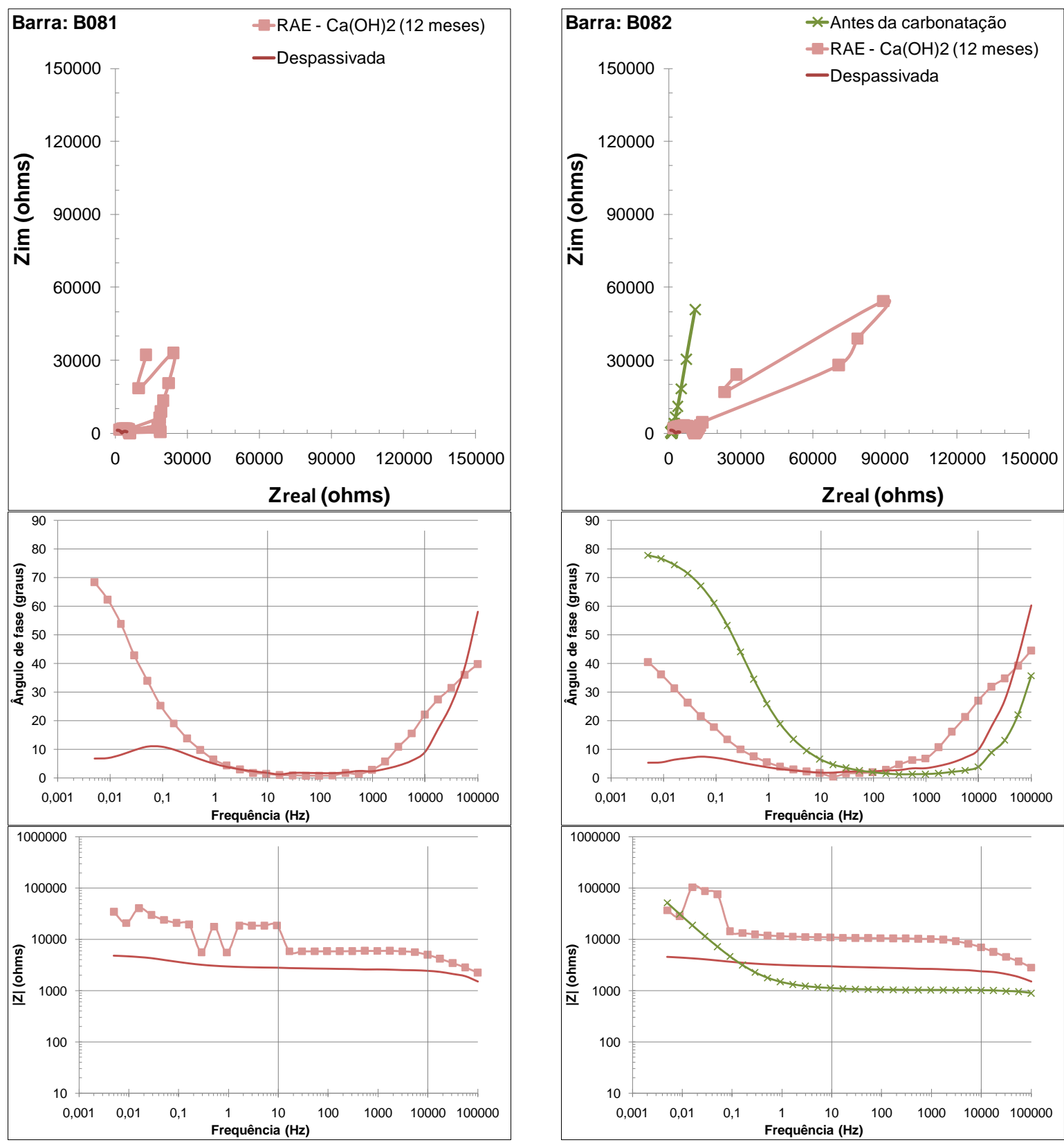
$\underline{\text { RELAÇÃO A/C 0,80 COM CURA DE } 1 \text { DIA }}$

RAE: com solução alcalina de hidróxido de cálcio saturado $\left(\mathrm{Ca}(\mathrm{OH})_{2}\right)$
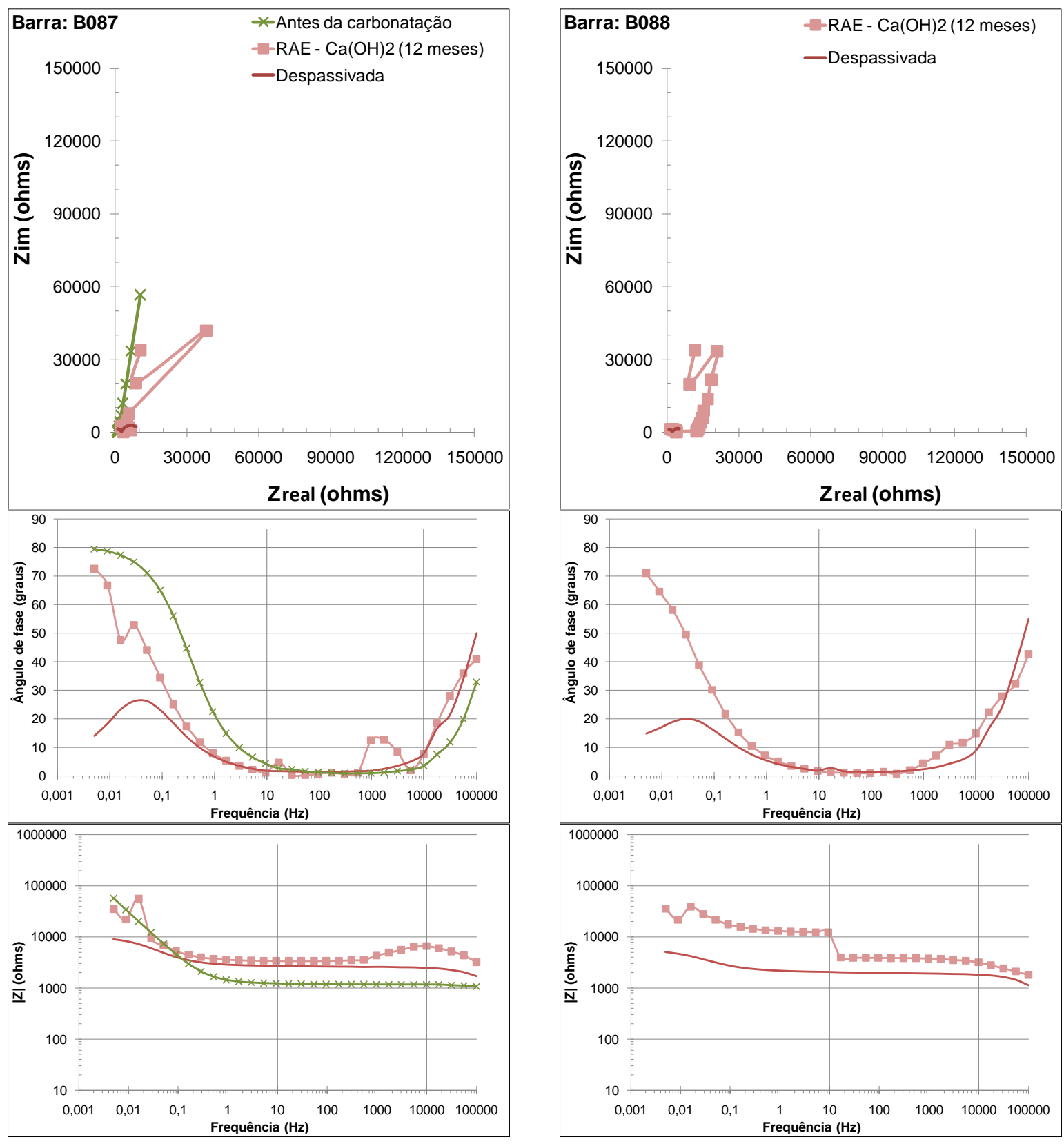


\section{$\underline{\text { RELAÇÃO A/C 0,80 COM CURA DE } 28 \text { DIAS }}$}

RAE: com solução alcalina de carbonato de sódio a $1 \mathrm{M}\left(\mathrm{Na}_{2} \mathrm{CO}_{3}\right)$
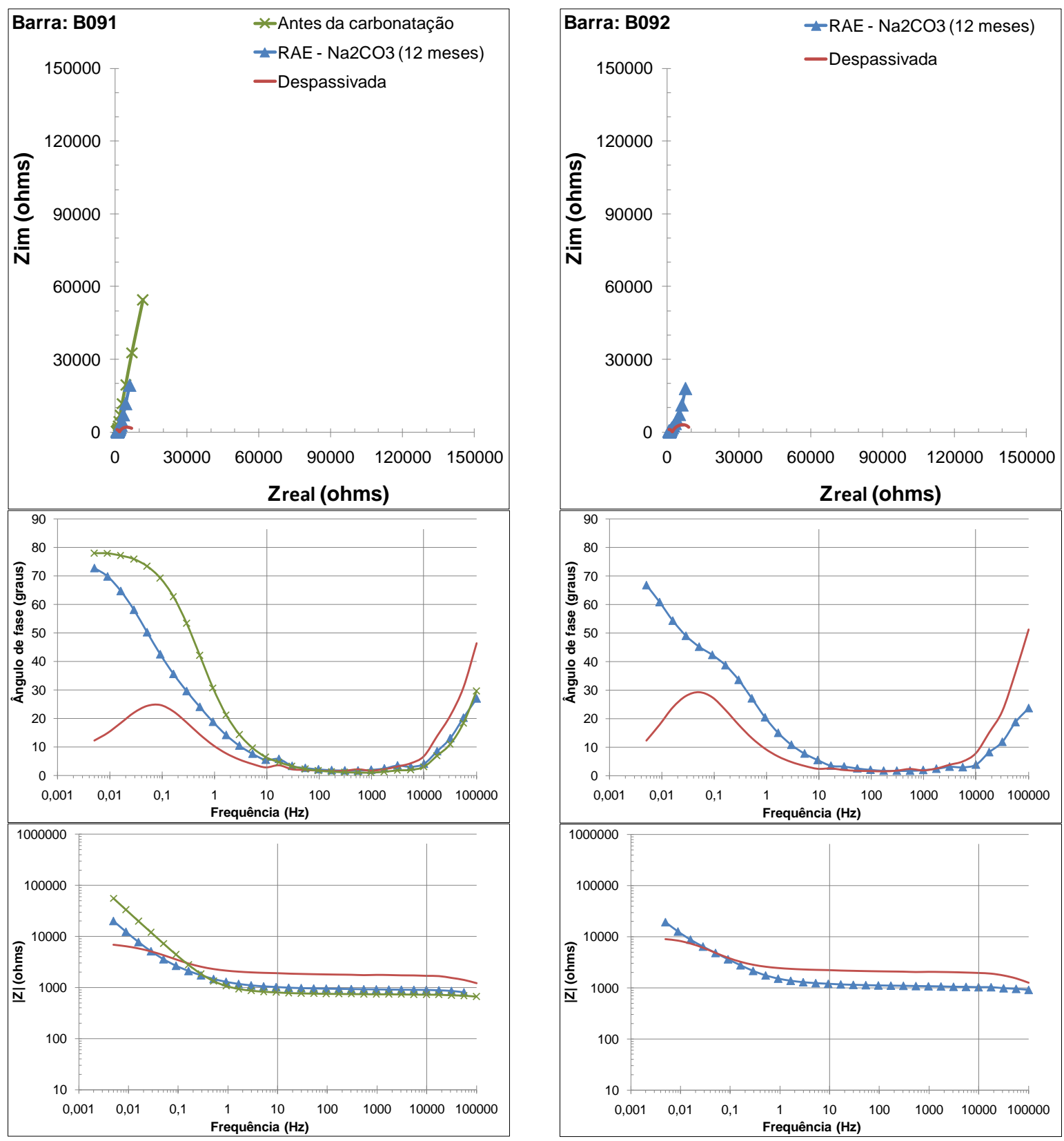


\section{$\underline{\text { RELAÇÃO A/C 0,80 COM CURA DE } 28 \text { DIAS }}$}

RAE: com solução alcalina de carbonato de sódio a $1 \mathrm{M}\left(\mathrm{Na}_{2} \mathrm{CO}_{3}\right)$
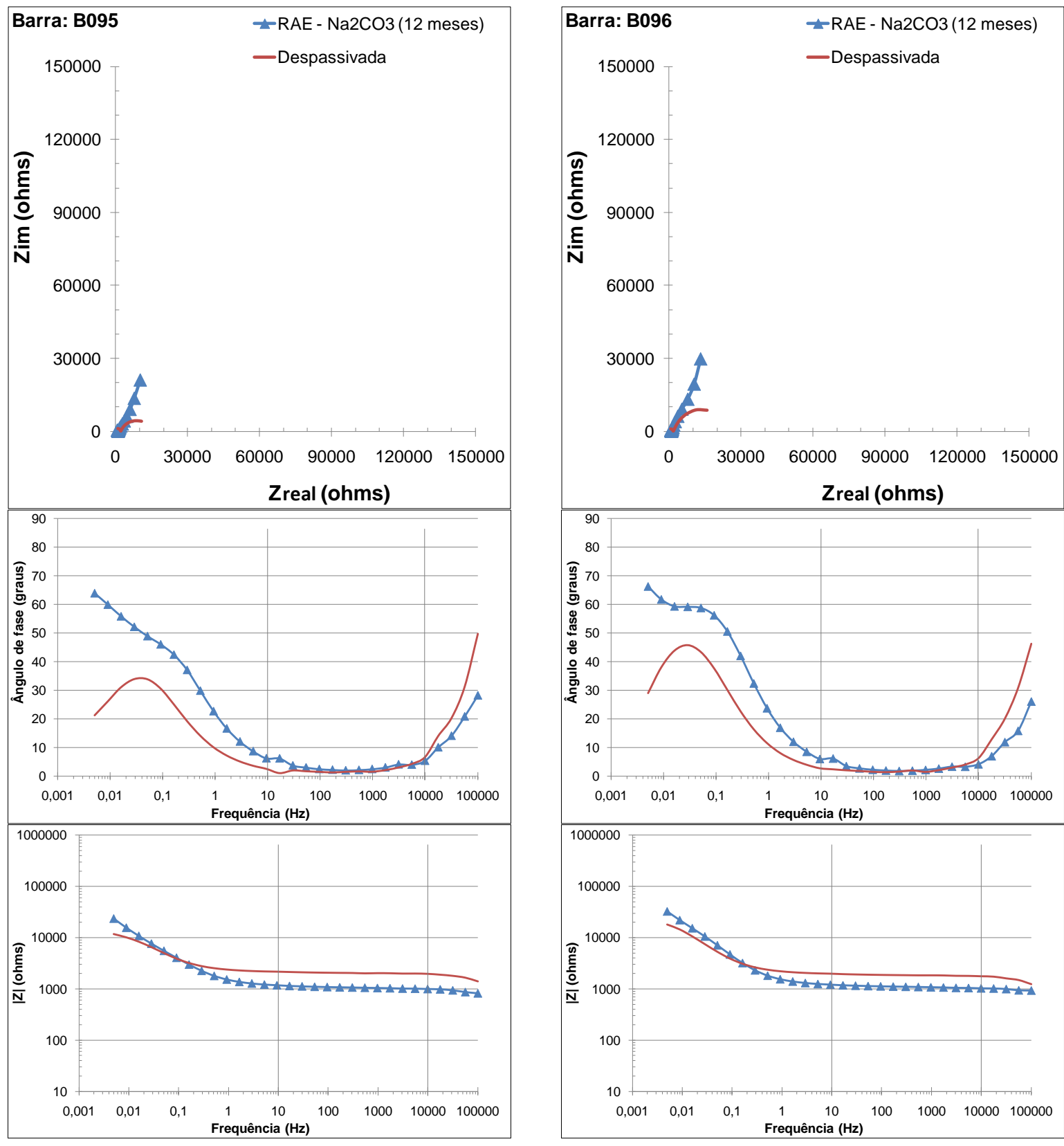


\section{$\underline{\text { RELAÇÃO A/C 0,80 COM CURA DE } 28 \text { DIAS }}$}

RAE: com solução alcalina de hidróxido de potássio a 2M (KOH)
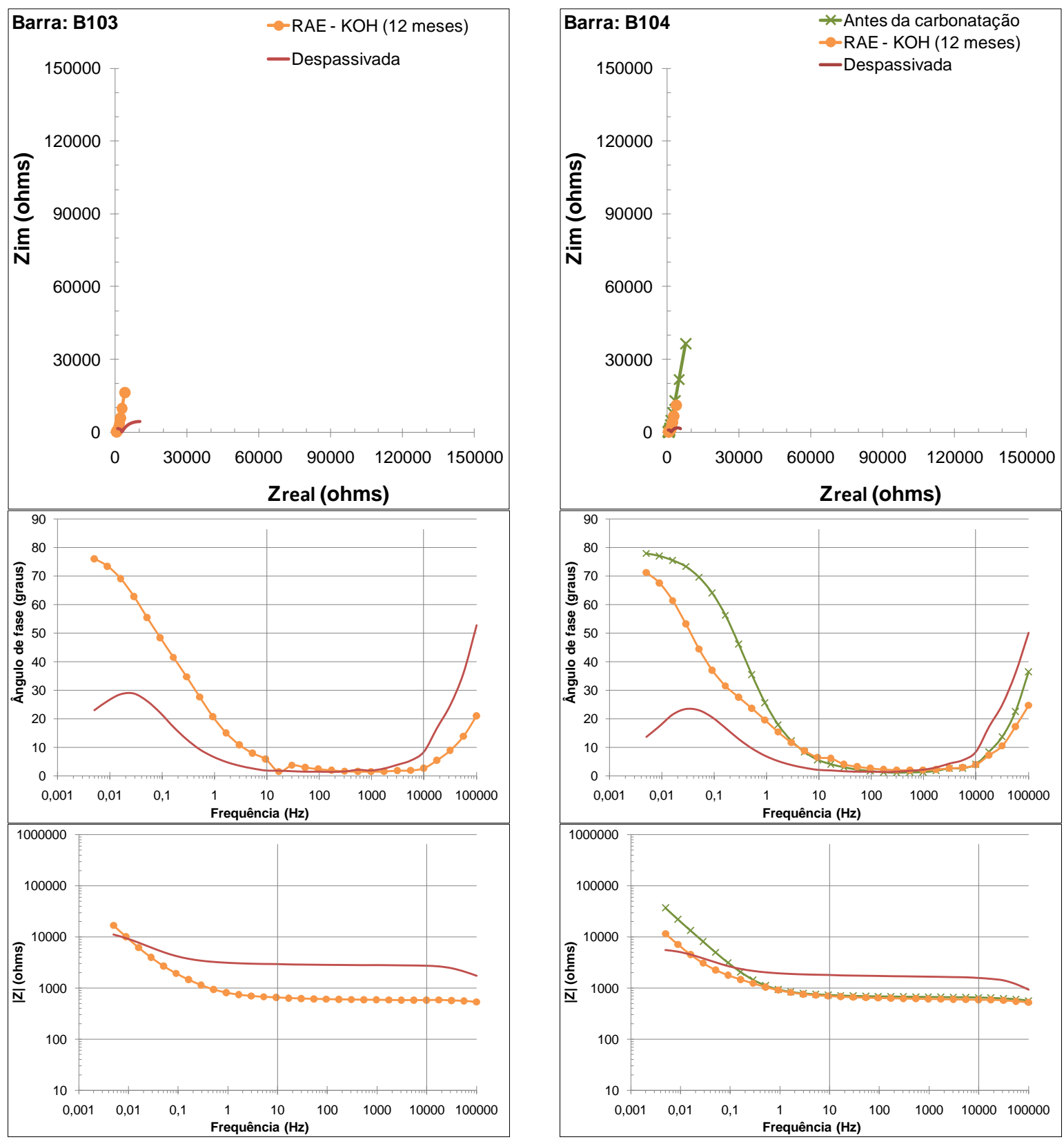


\section{$\underline{\text { RELAÇÃO A/C 0,80 COM CURA DE } 28 \text { DIAS }}$}

RAE: com solução alcalina de hidróxido de potássio a 2M (KOH)
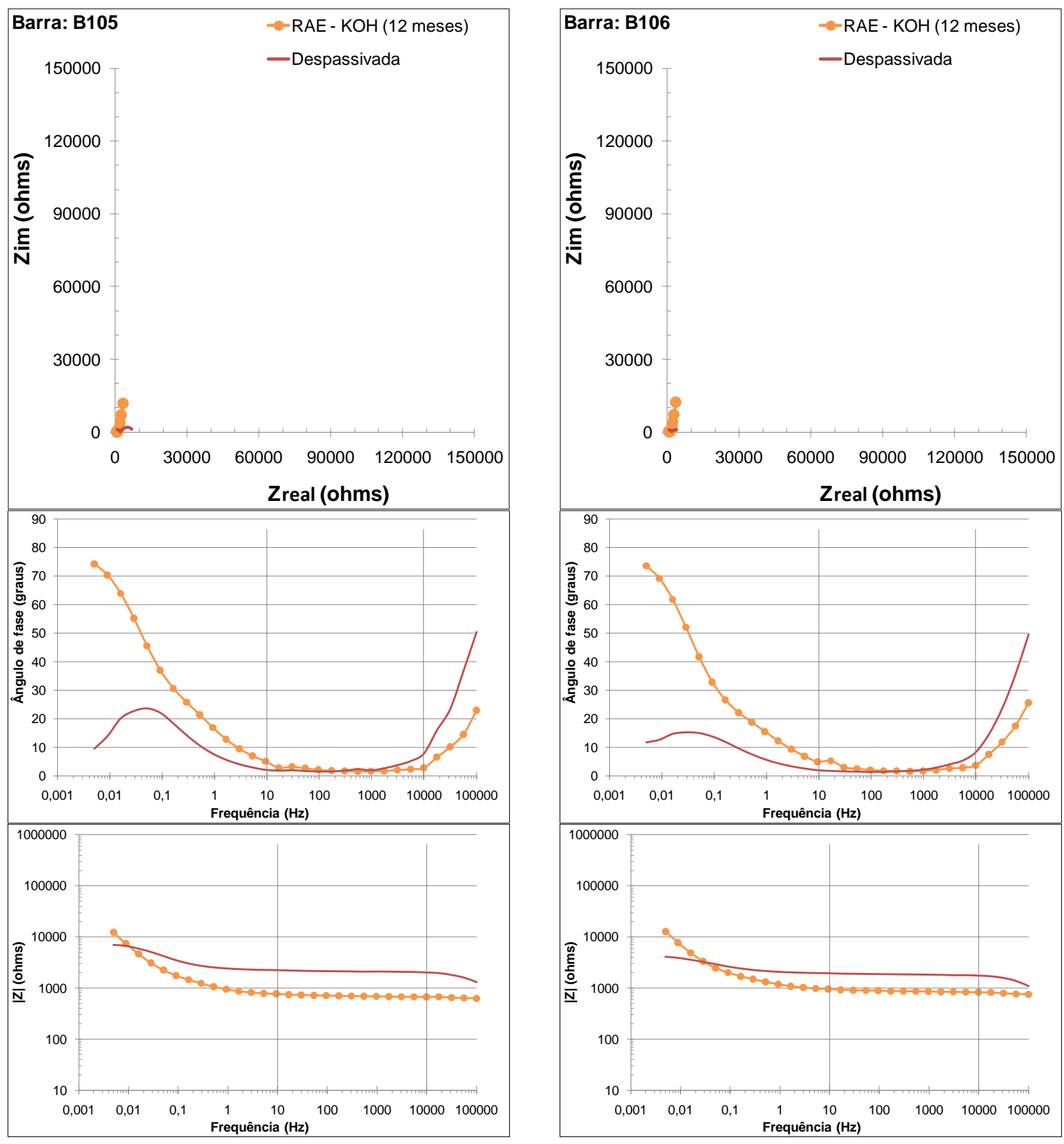


\section{$\underline{\text { RELAÇÃO A/C 0,80 COM CURA DE } 28 \text { DIAS }}$}

RAE: com solução alcalina de hidróxido de cálcio saturado $\left(\mathrm{Ca}(\mathrm{OH})_{2}\right)$
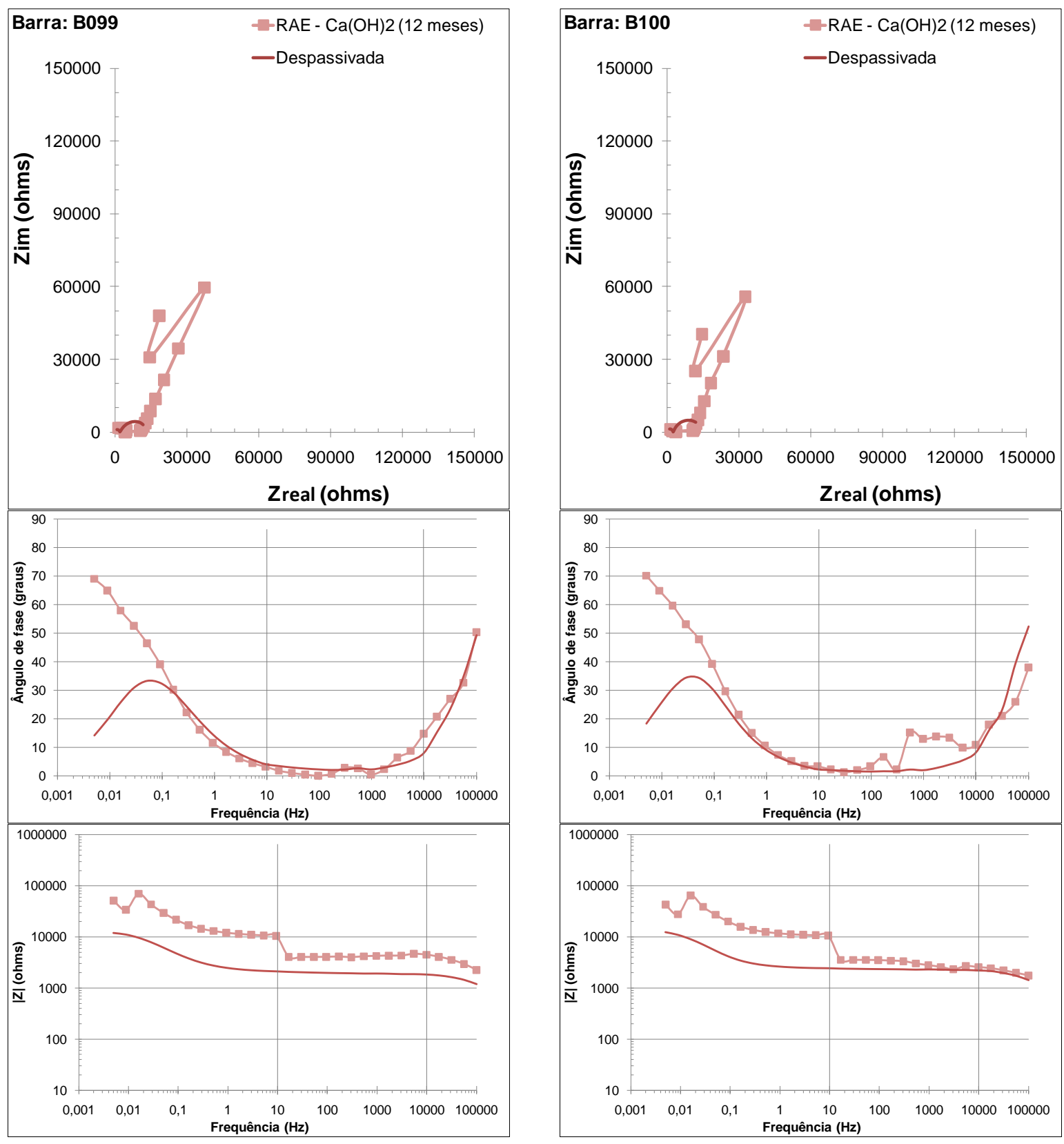


\section{$\underline{\text { RELAÇÃO A/C 0,80 COM CURA DE } 28 \text { DIAS }}$}

RAE: com solução alcalina de hidróxido de cálcio saturado $\left(\mathrm{Ca}(\mathrm{OH})_{2}\right)$
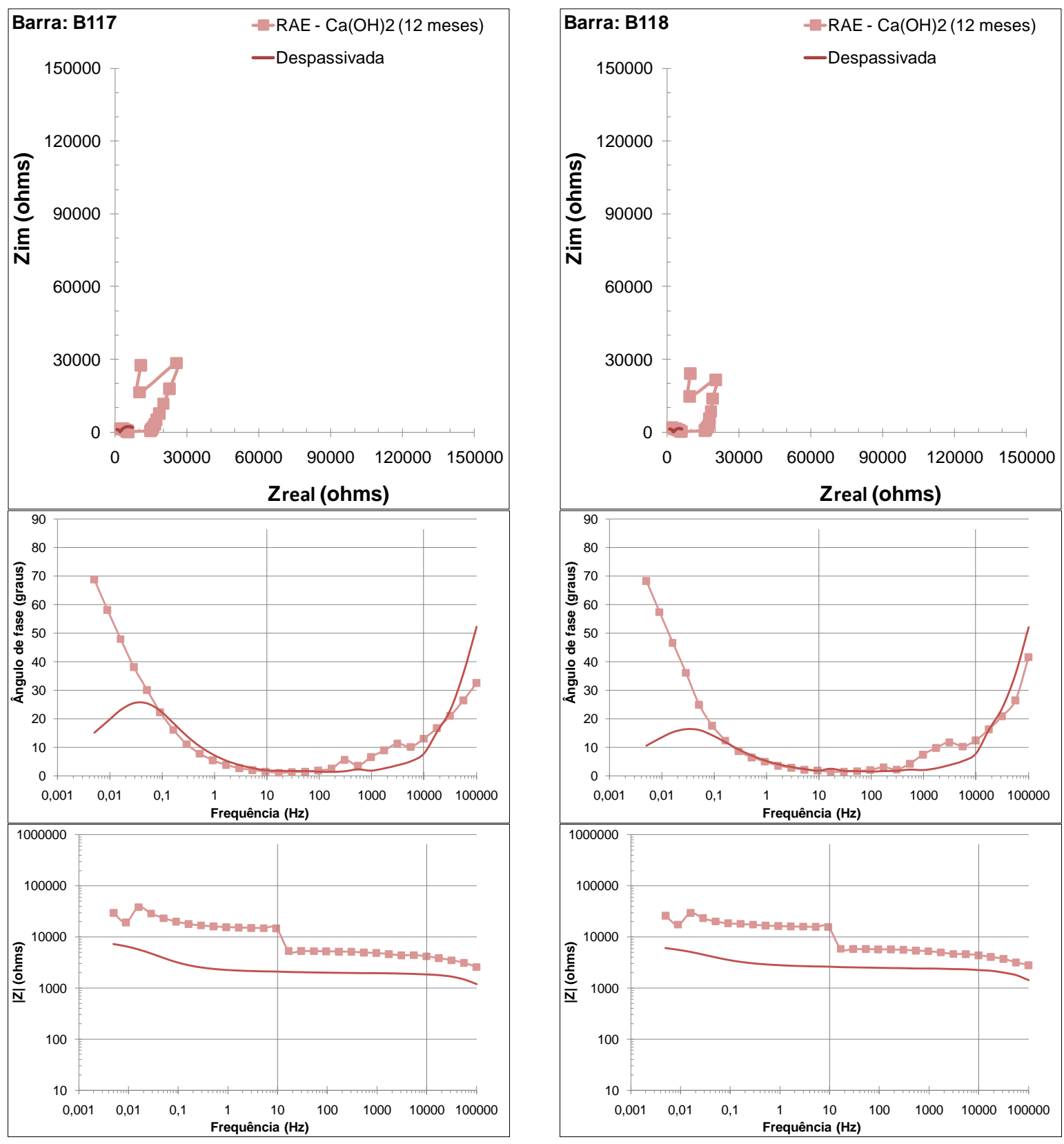


\section{RESUltados DE EIE: CORPOS-DE-PROVA ANTES DA CARBONATAÇÃO, CARBONATADOS E REALCALINIZADOS PELA RAQ}

\section{$\underline{\text { RELAÇÃO A/C 0,65 COM CURA DE } 1 \text { DIA }}$}

RAQ: com solução alcalina de carbonato de sódio a $1 \mathrm{M}\left(\mathrm{Na}_{2} \mathrm{CO}_{3}\right)$
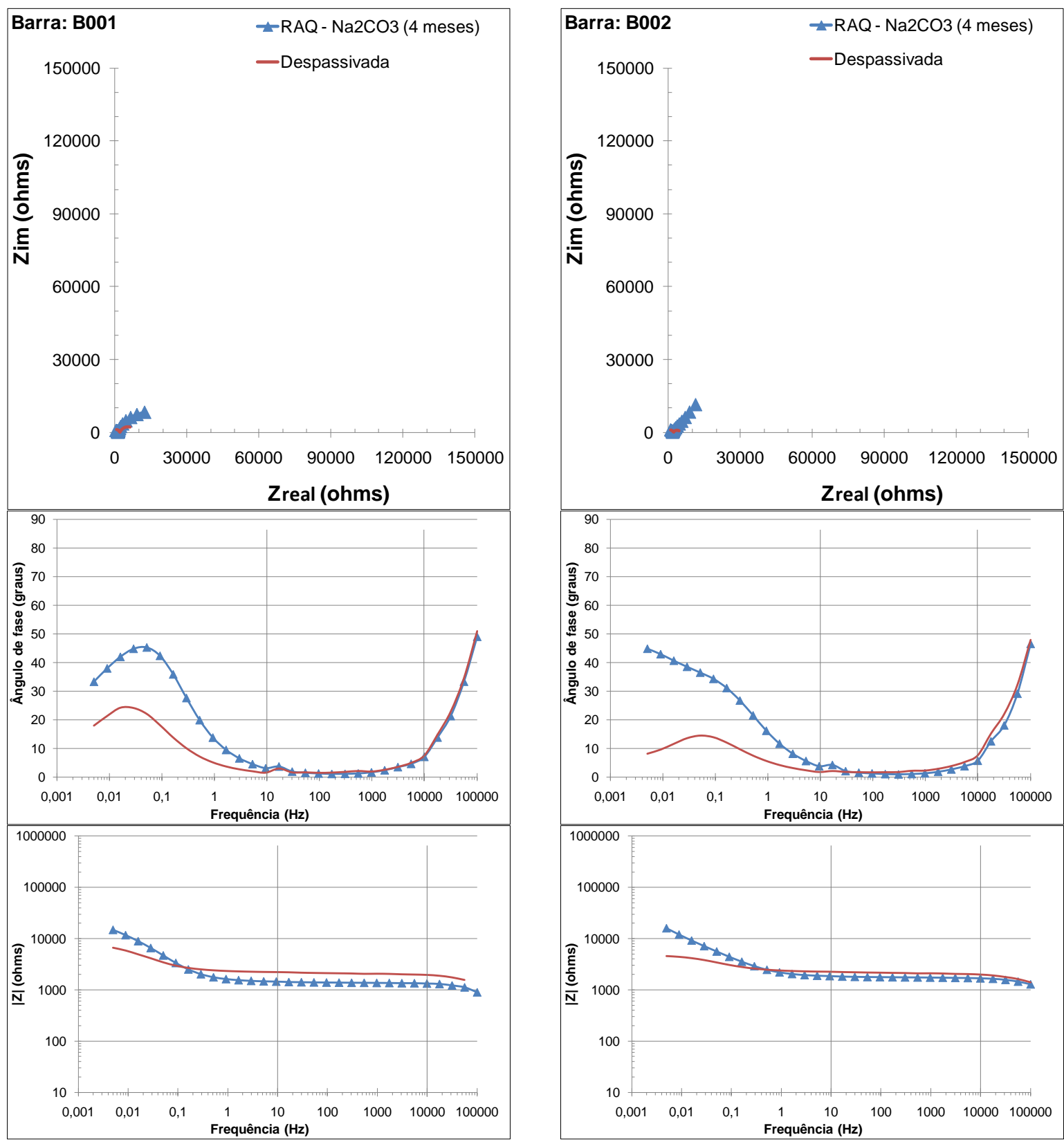
$\underline{\text { RELAÇÃO A/C 0,65 COM CURA DE } 1 \text { DIA }}$

RAQ: com solução alcalina de carbonato de sódio a $1 \mathrm{M}\left(\mathrm{Na}_{2} \mathrm{CO}_{3}\right)$
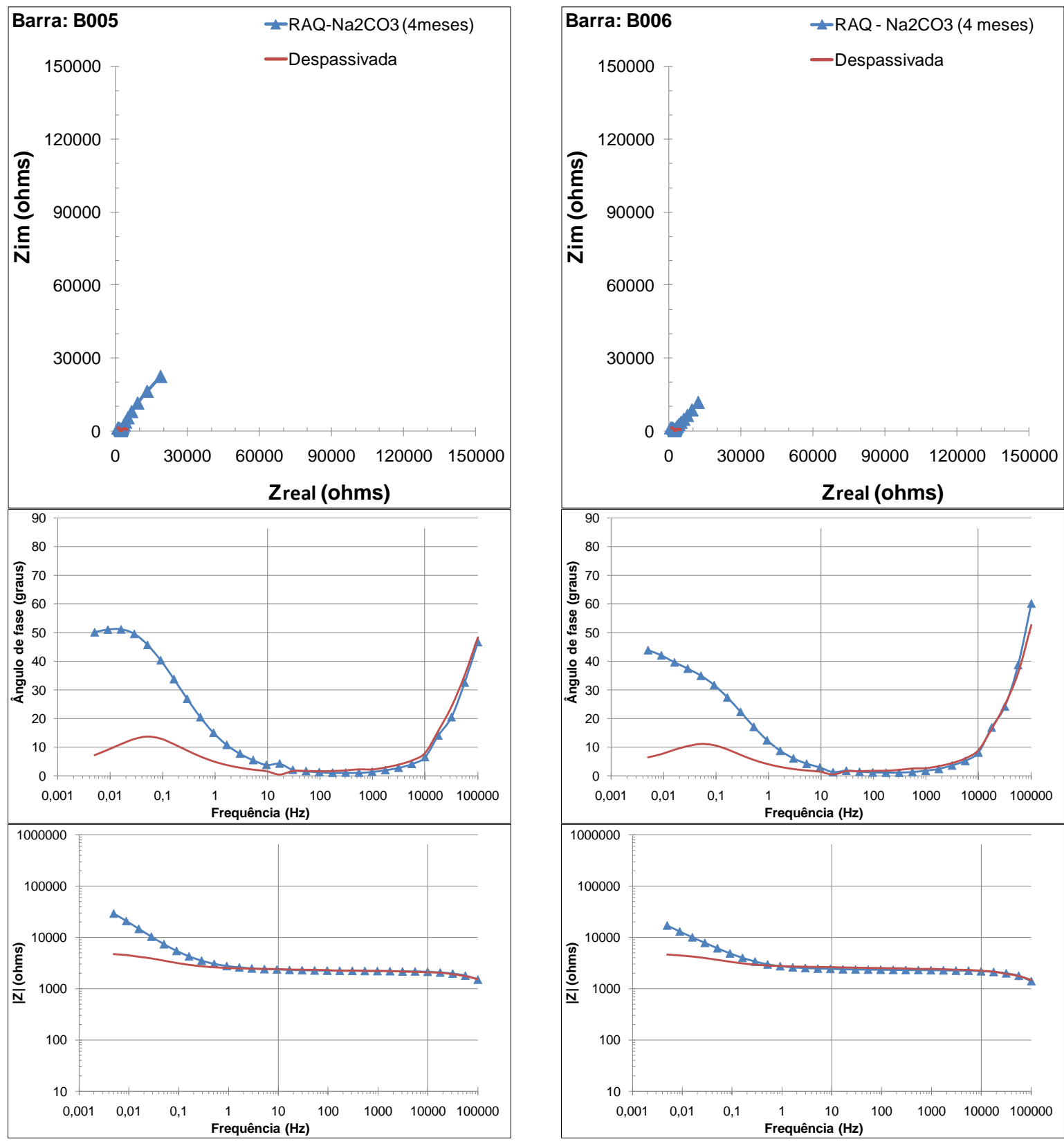
$\underline{\text { RELAÇÃO A/C 0,65 COM CURA DE } 1 \text { DIA }}$

RAQ: com solução alcalina de hidróxido de potássio a 2M (KOH)
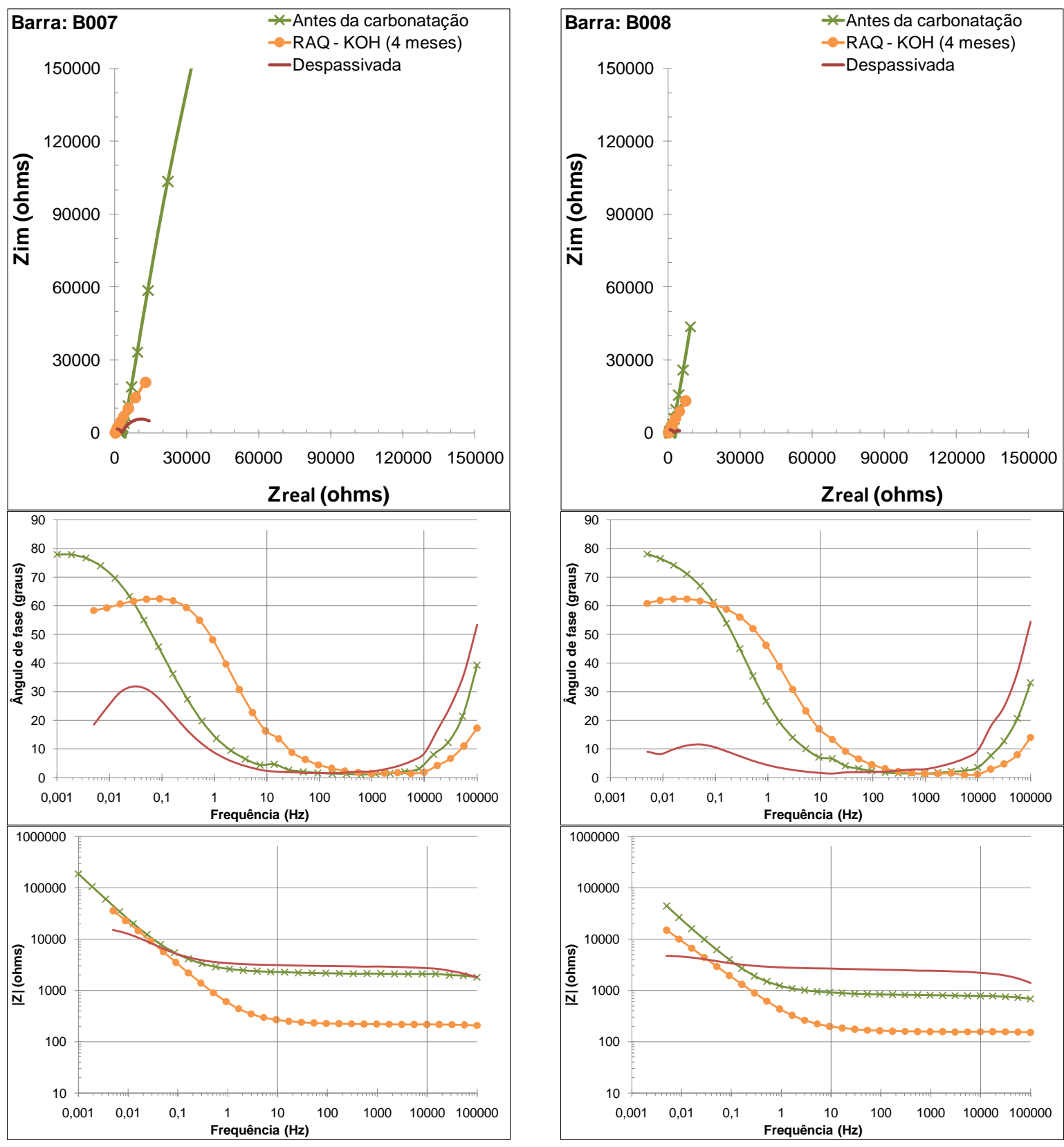
$\underline{\text { RELAÇÃO A/C 0,65 COM CURA DE } 1 \text { DIA }}$

RAQ: com solução alcalina de hidróxido de potássio a 2M (KOH)
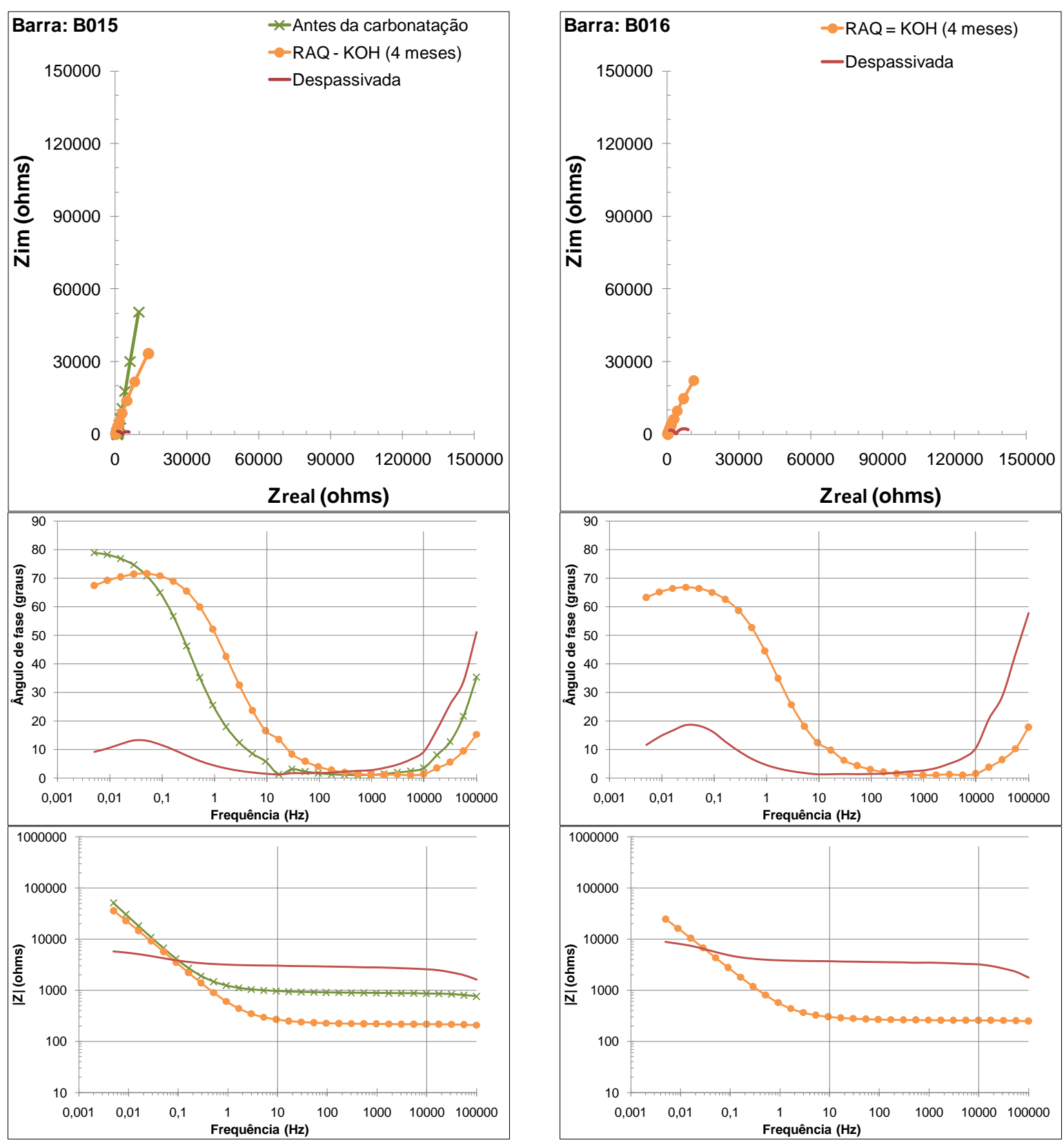


\section{$\underline{\text { RELAÇ̃̃O A/C 0,65 COM CURA DE } 1 \text { DIA }}$}

RAQ: com solução alcalina de hidróxido de cálcio saturado $\left(\mathrm{Ca}(\mathrm{OH})_{2}\right)$
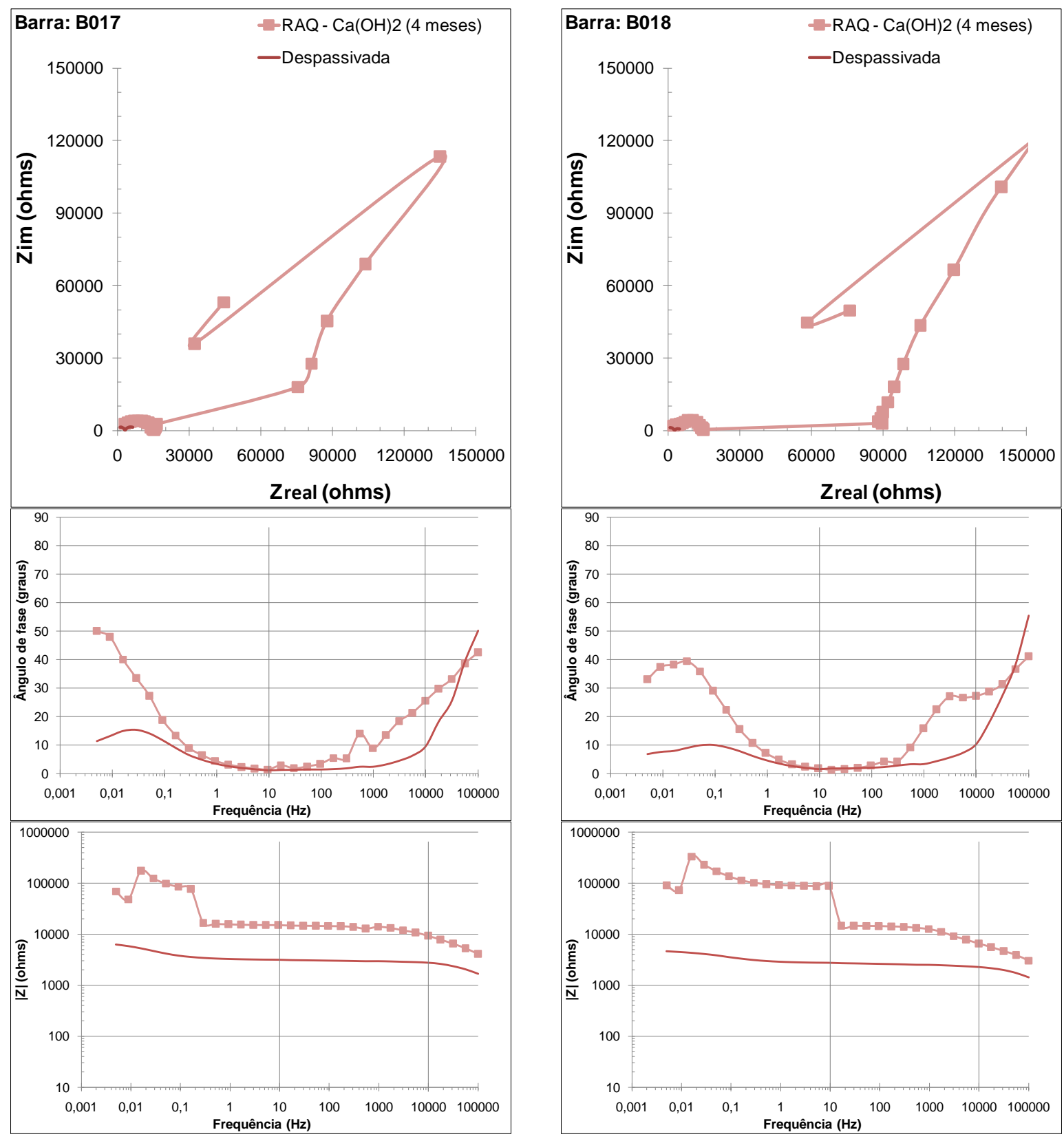
$\underline{\text { RELAÇÃO A/C 0,65 COM CURA DE } 1 \text { DIA }}$

RAQ: com solução alcalina de hidróxido de cálcio saturado $\left(\mathrm{Ca}(\mathrm{OH})_{2}\right)$
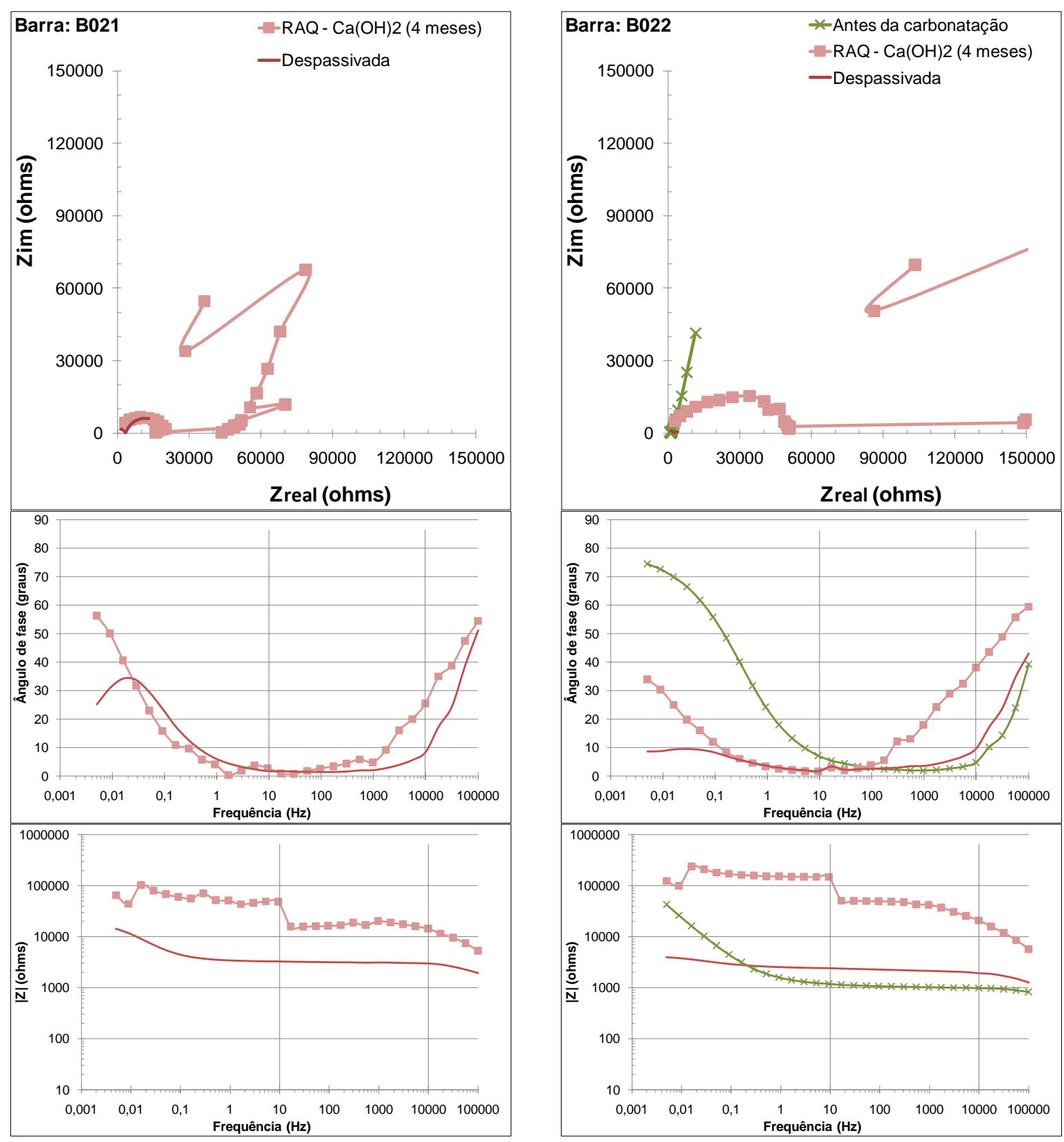


\section{$\underline{\text { RELAÇÃO A/C 0,65 COM CURA DE } 28 \text { DIAS }}$}

RAQ: com solução alcalina de carbonato de sódio a $1 \mathrm{M}\left(\mathrm{Na}_{2} \mathrm{CO}_{3}\right)$
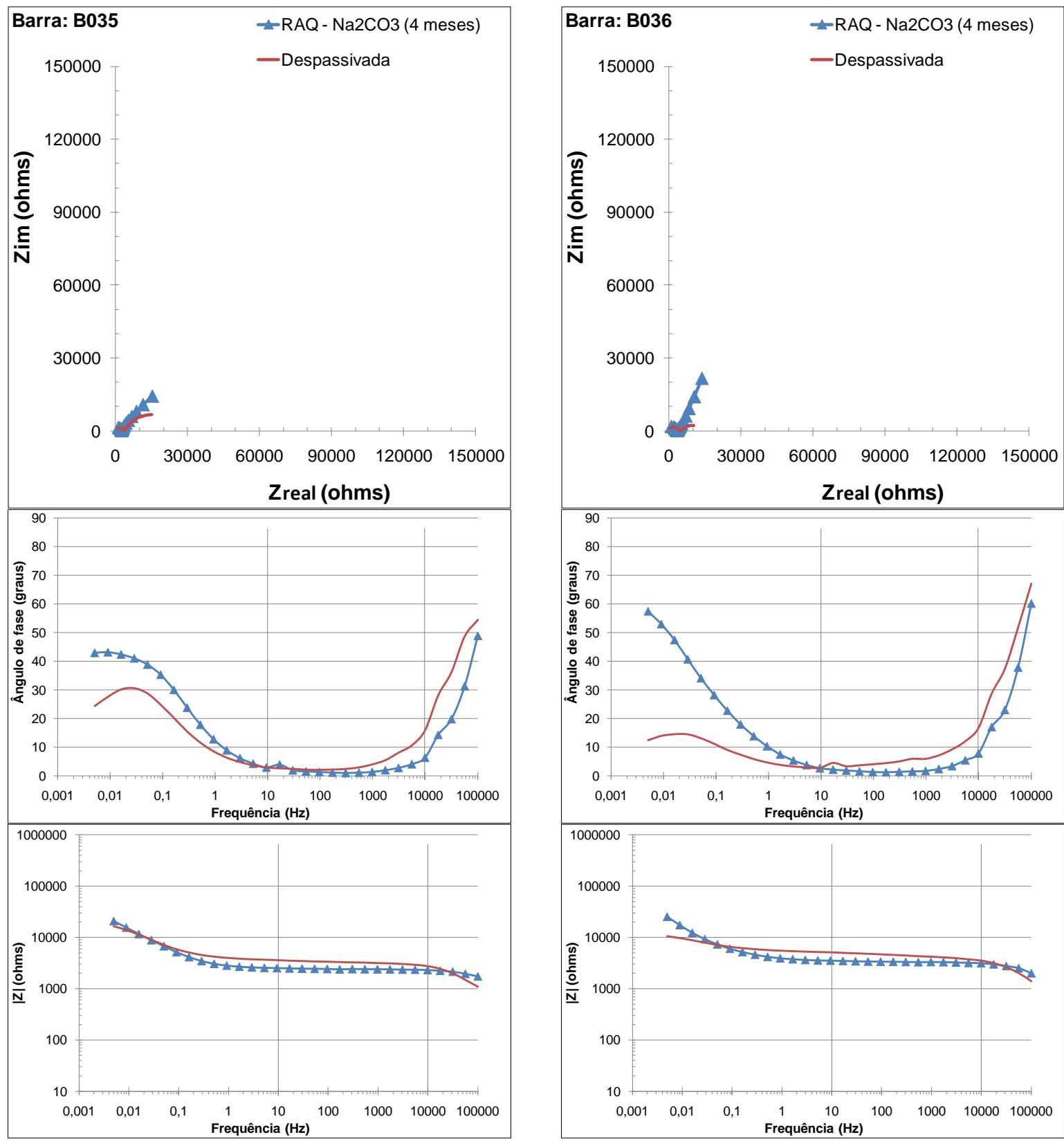


\section{$\underline{\text { RELAÇÃO A/C 0,65 COM CURA DE } 28 \text { DIAS }}$}

RAQ: com solução alcalina de carbonato de sódio a $1 \mathrm{M}\left(\mathrm{Na}_{2} \mathrm{CO}_{3}\right)$
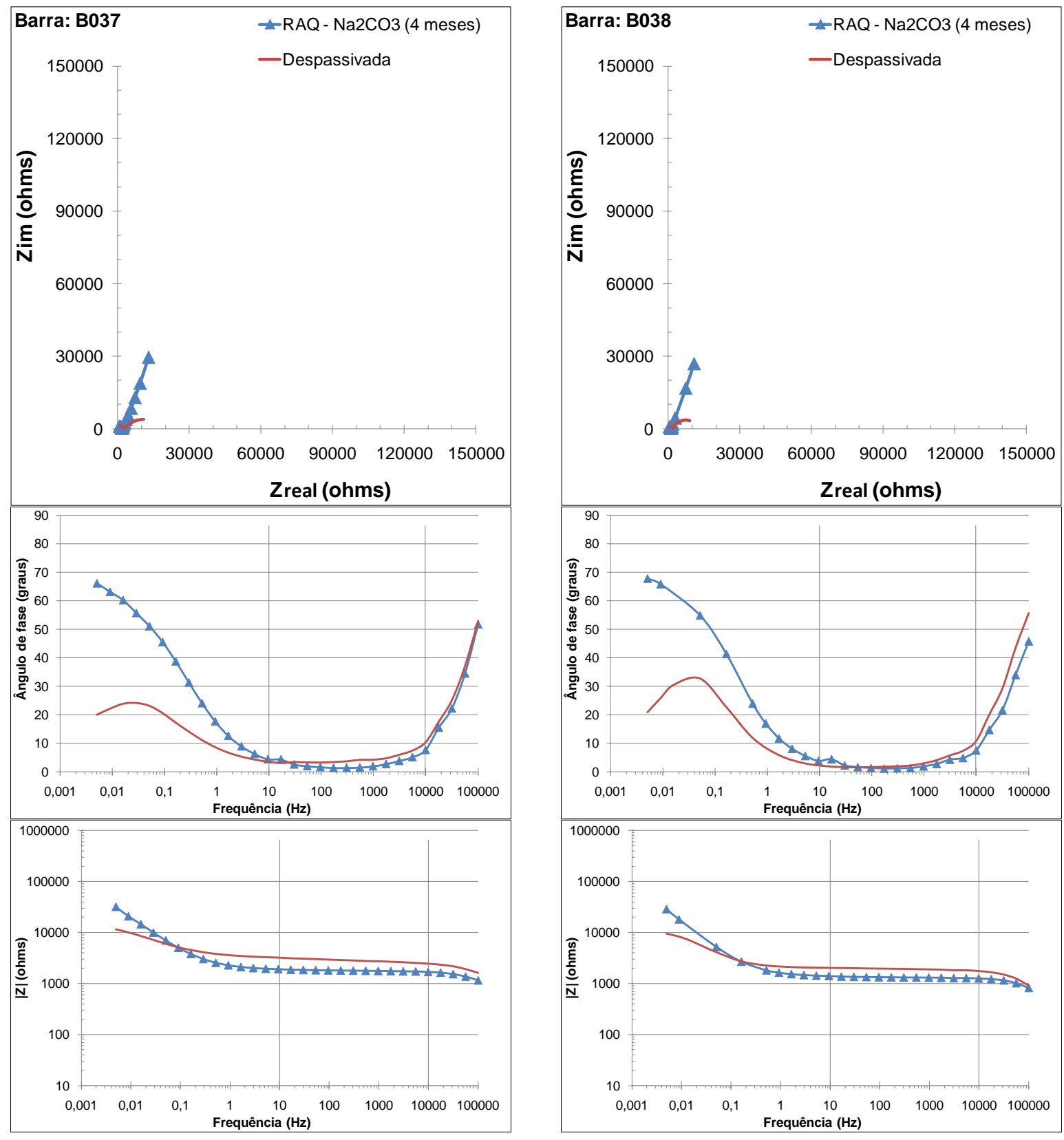
$\underline{\text { RELAČ̃̃O A/C 0,65 COM CURA DE } 28 \text { DIAS }}$

RAQ: com solução alcalina de hidróxido de potássio a 2M (KOH)
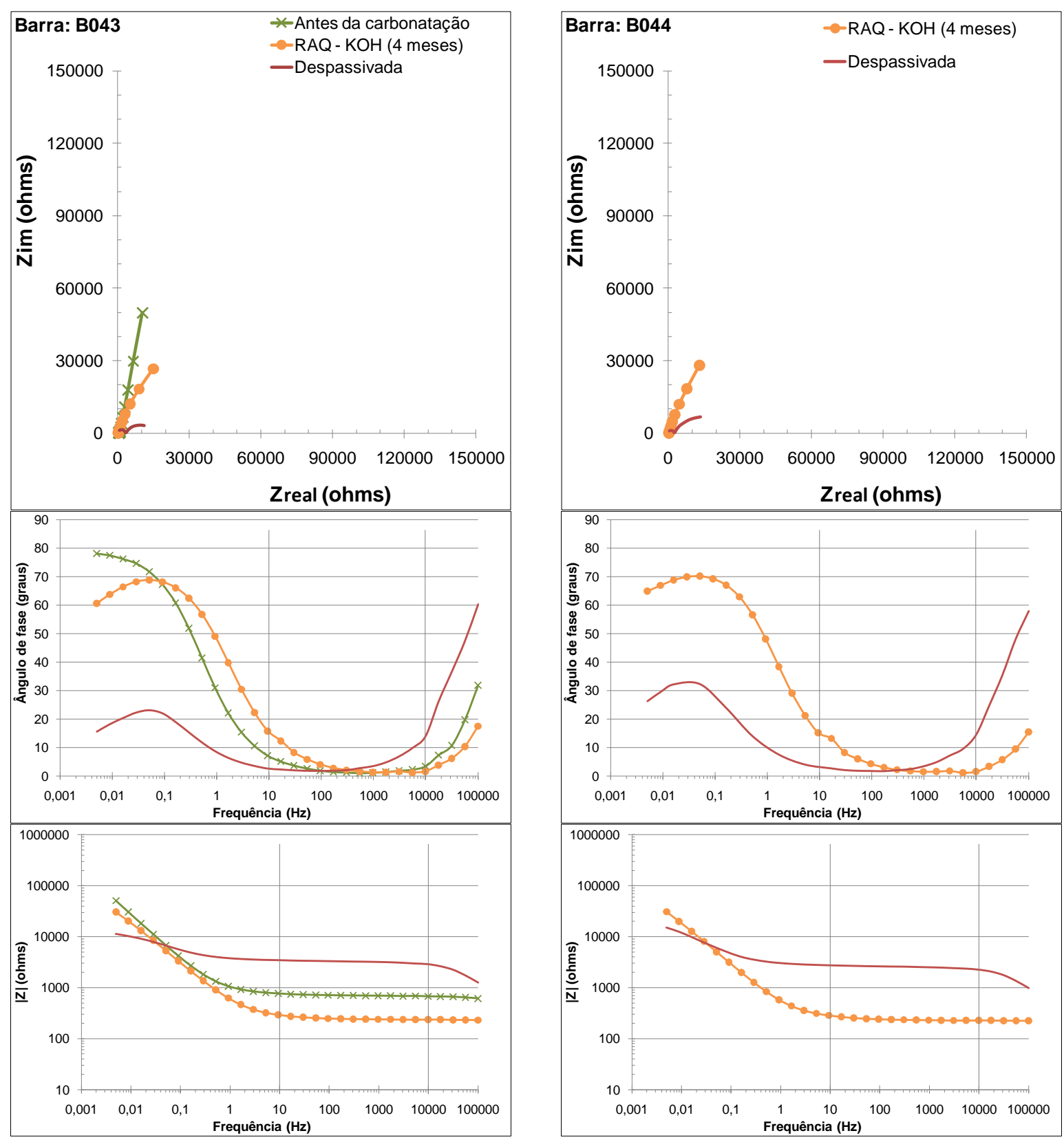
$\underline{\text { RELAÇÃO A/C 0,65 COM CURA DE } 28 \text { DIAS }}$

RAQ: com solução alcalina de hidróxido de potássio a 2M (KOH)
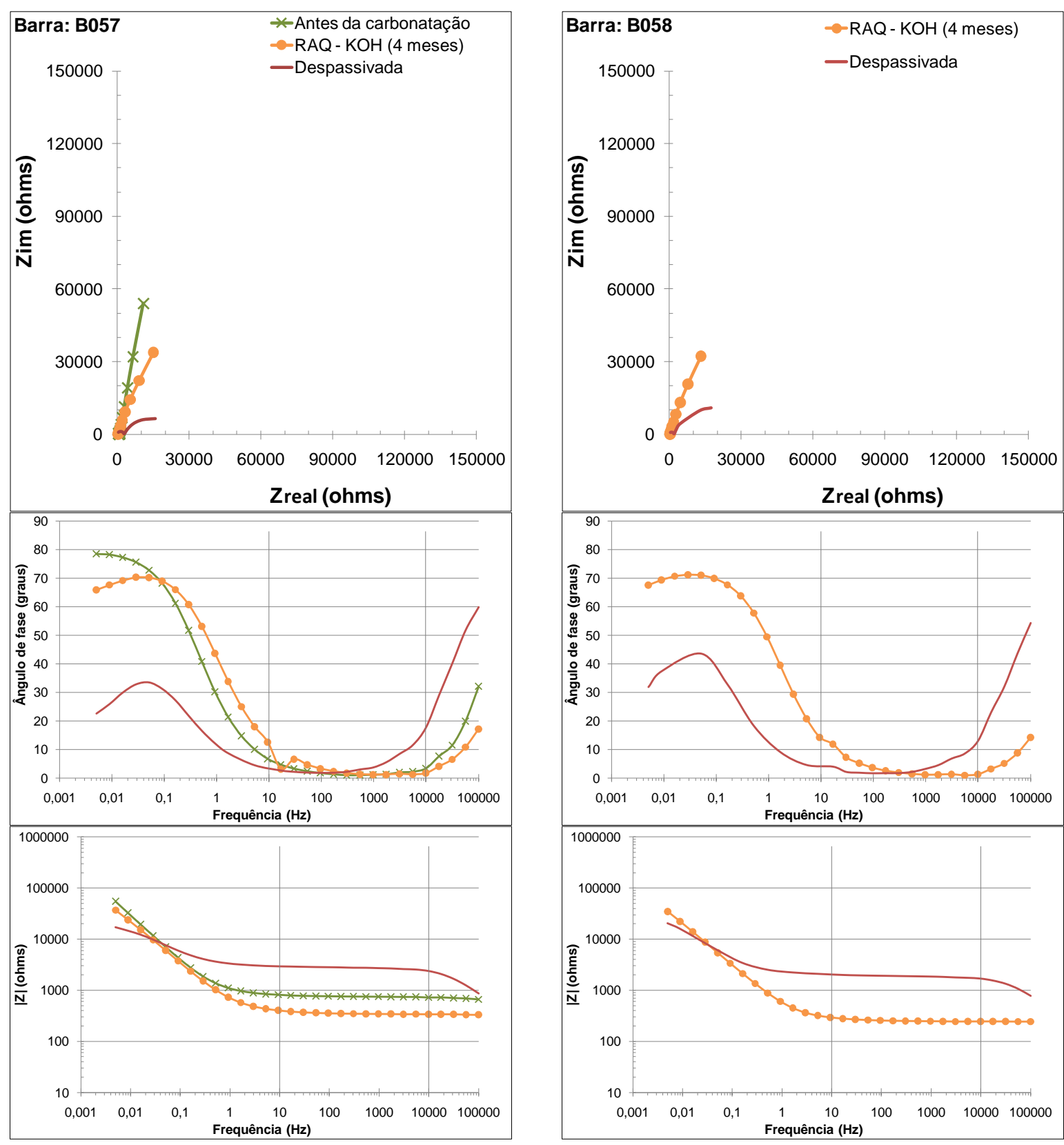


\section{$\underline{\text { RELAÇÃO A/C 0,65 COM CURA DE } 28 \text { DIAS }}$}

RAQ: com solução alcalina de hidróxido de cálcio saturado $\left(\mathrm{Ca}(\mathrm{OH})_{2}\right)$
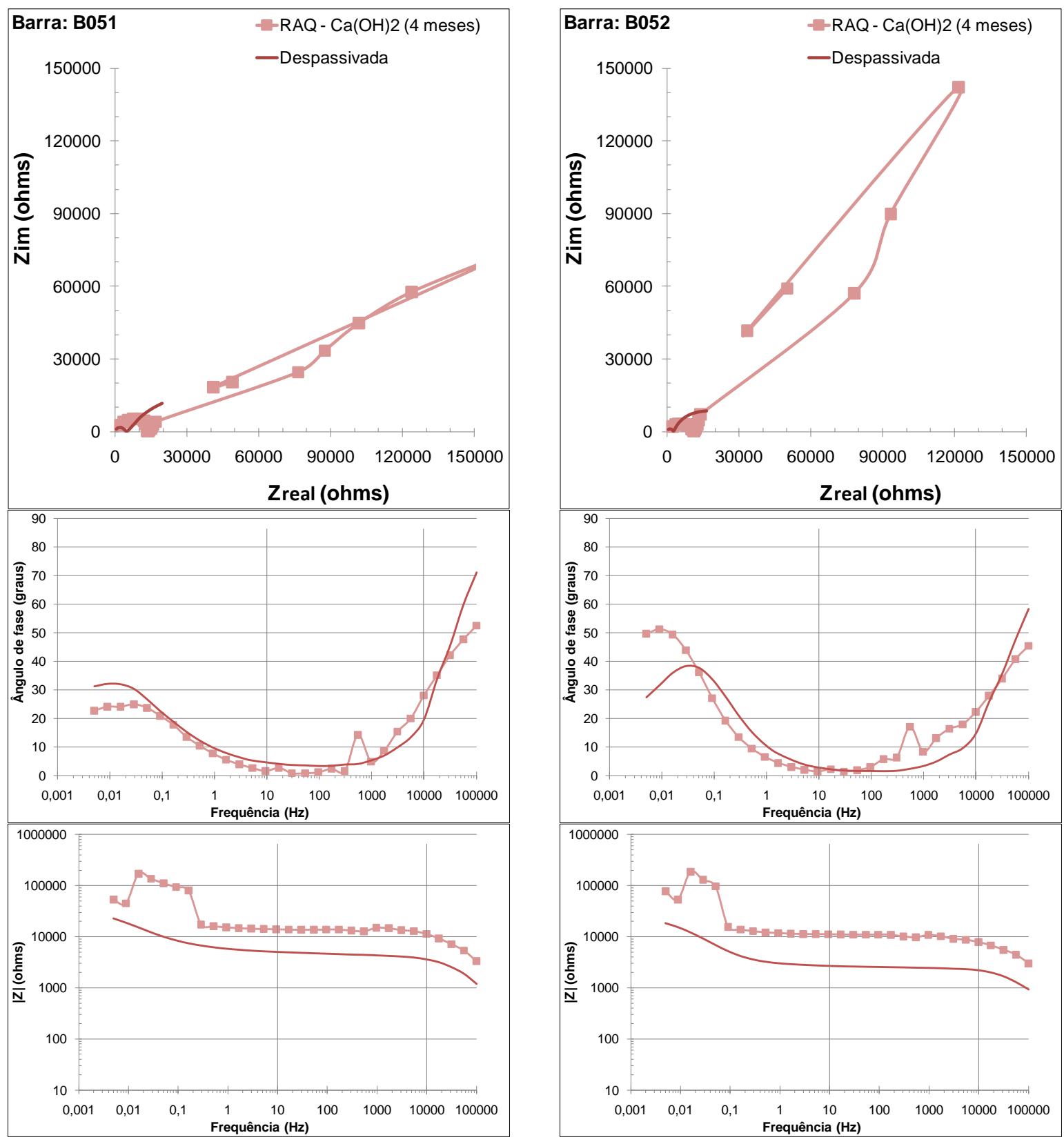
$\underline{\text { RELAČ̃̃O A/C 0,65 COM CURA DE } 28 \text { DIAS }}$

RAQ: com solução alcalina de hidróxido de cálcio saturado $\left(\mathrm{Ca}(\mathrm{OH})_{2}\right)$
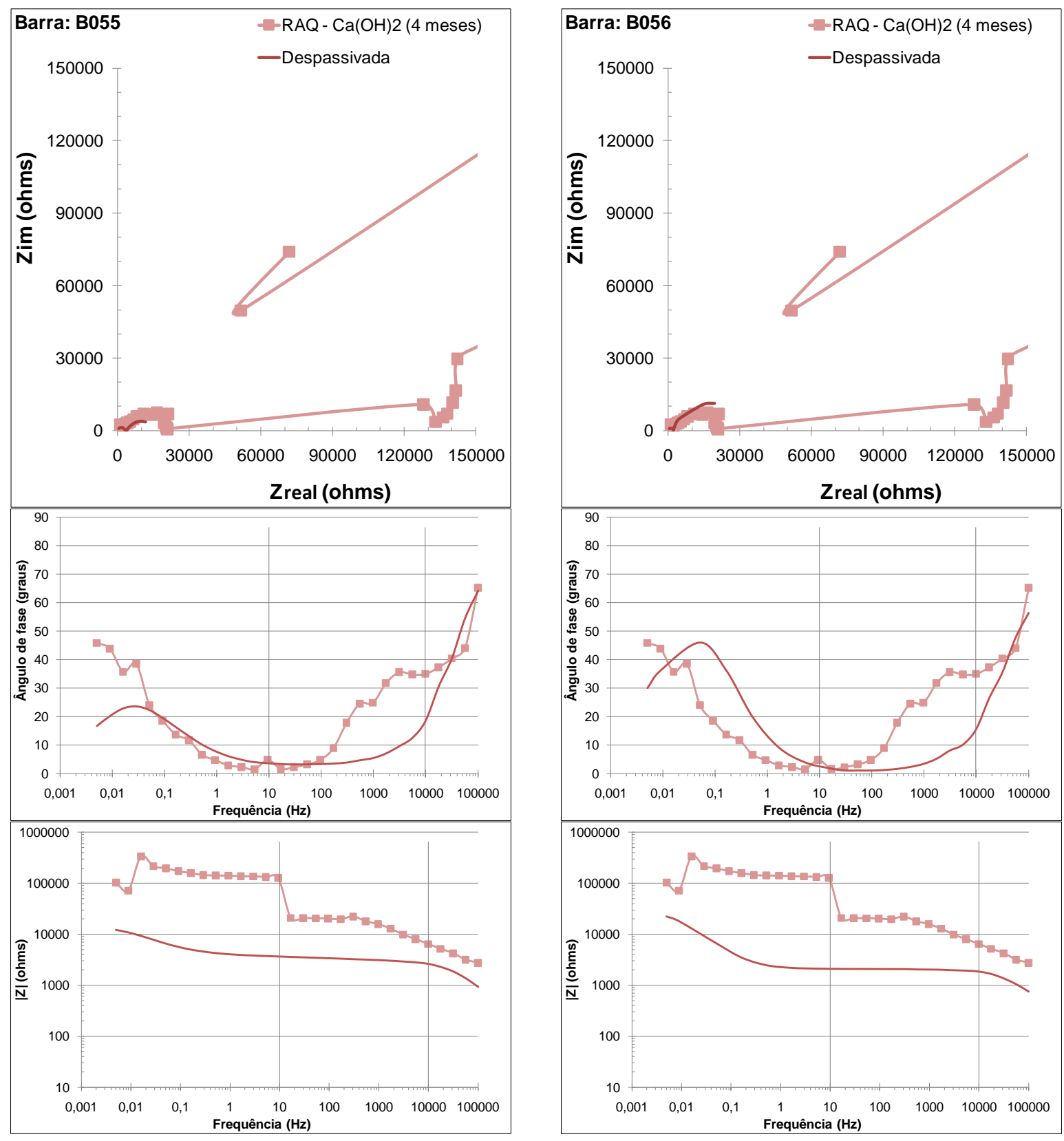
$\underline{\text { RELAÇÃO A/C 0,80 COM CURA DE } 1 \text { DIA }}$

RAQ: com solução alcalina de carbonato de sódio a $1 \mathrm{M}\left(\mathrm{Na}_{2} \mathrm{CO}_{3}\right)$
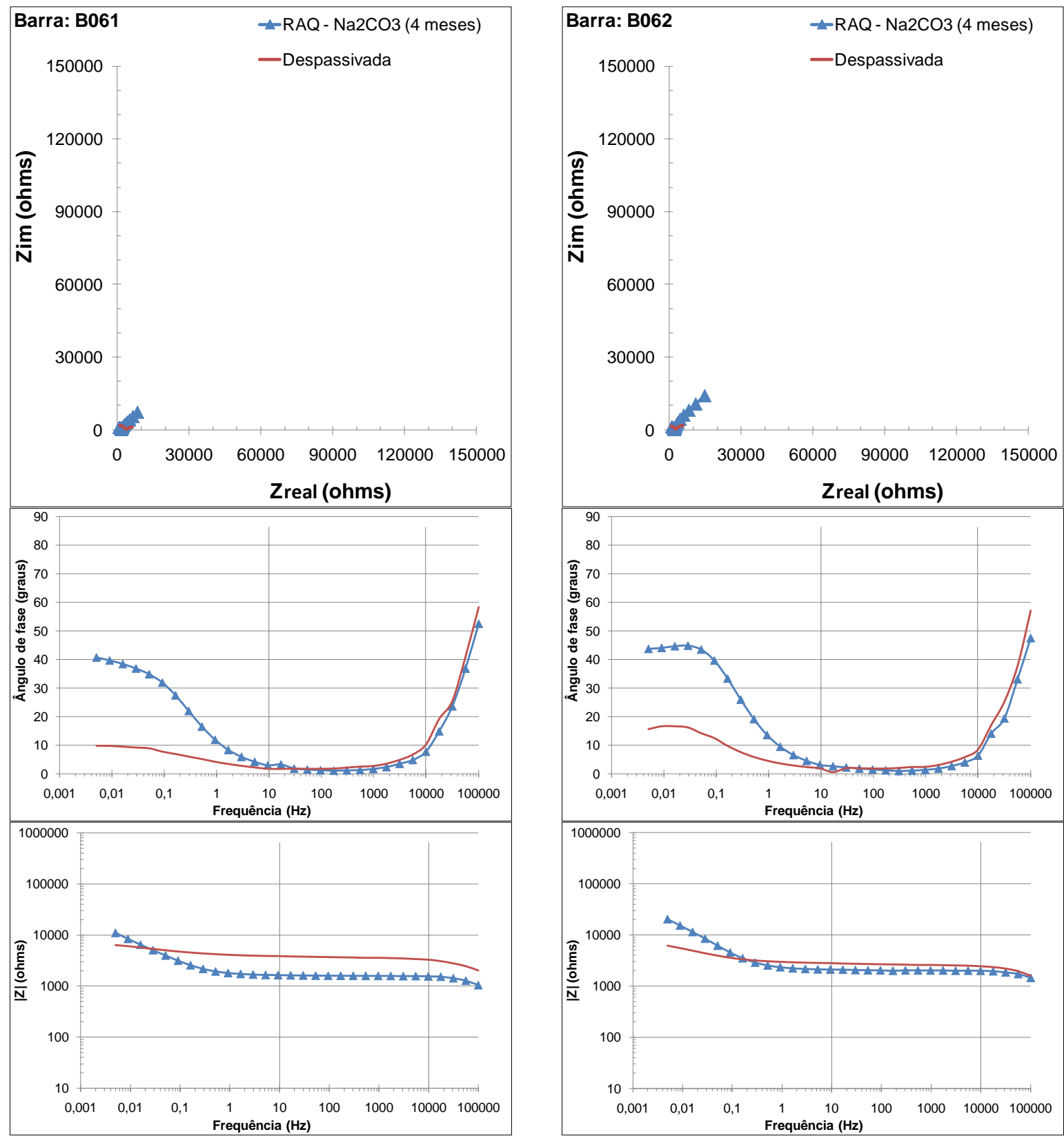
$\underline{\text { RELAÇÃO A/C 0,80 COM CURA DE } 1 \text { DIA }}$

RAQ: com solução alcalina de carbonato de sódio a $1 \mathrm{M}\left(\mathrm{Na}_{2} \mathrm{CO}_{3}\right)$
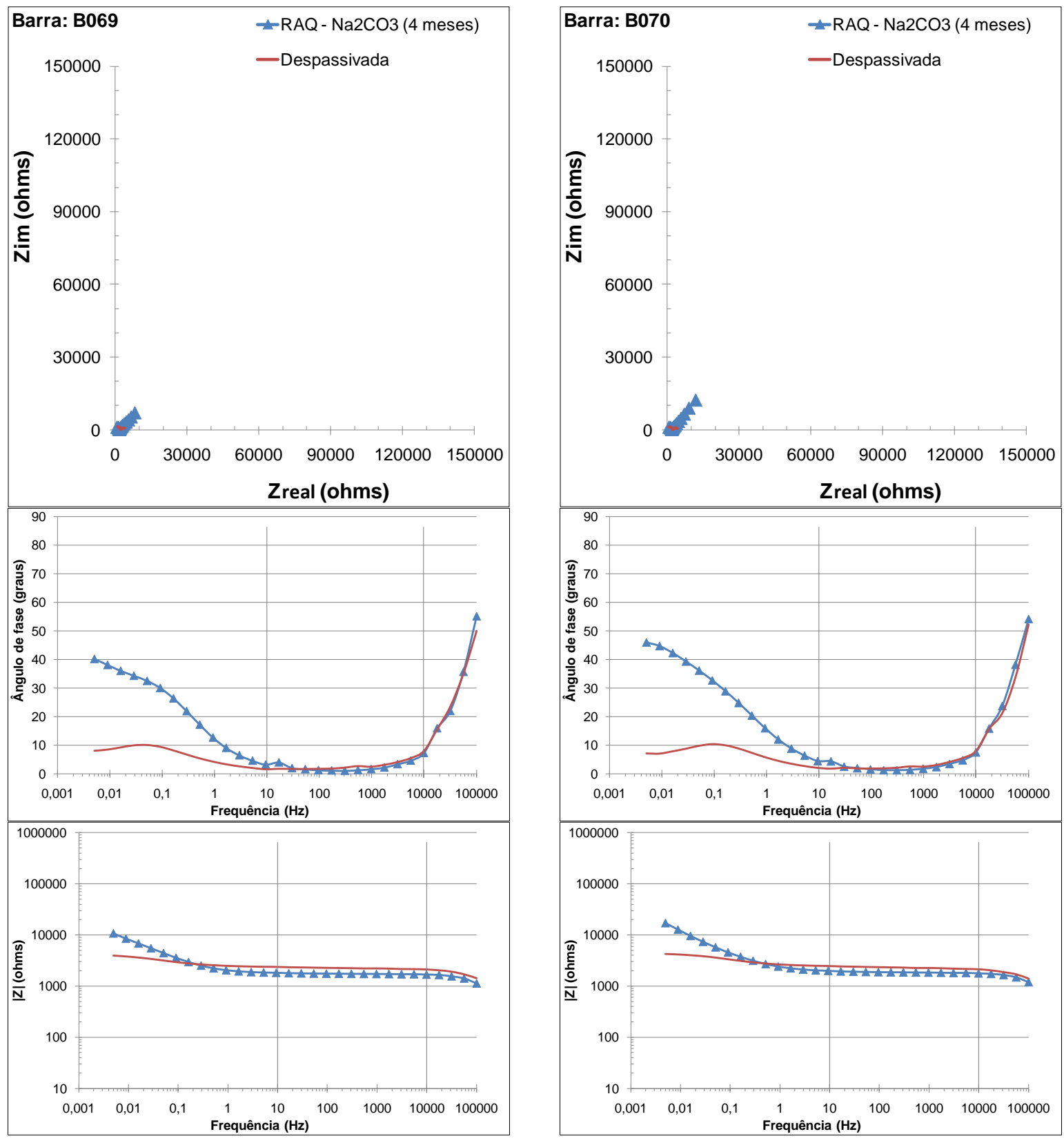
$\underline{\text { RELAÇÃO A/C 0,80 COM CURA DE } 1 \text { DIA }}$

RAQ: com solução alcalina de hidróxido de potássio a 2M (KOH)
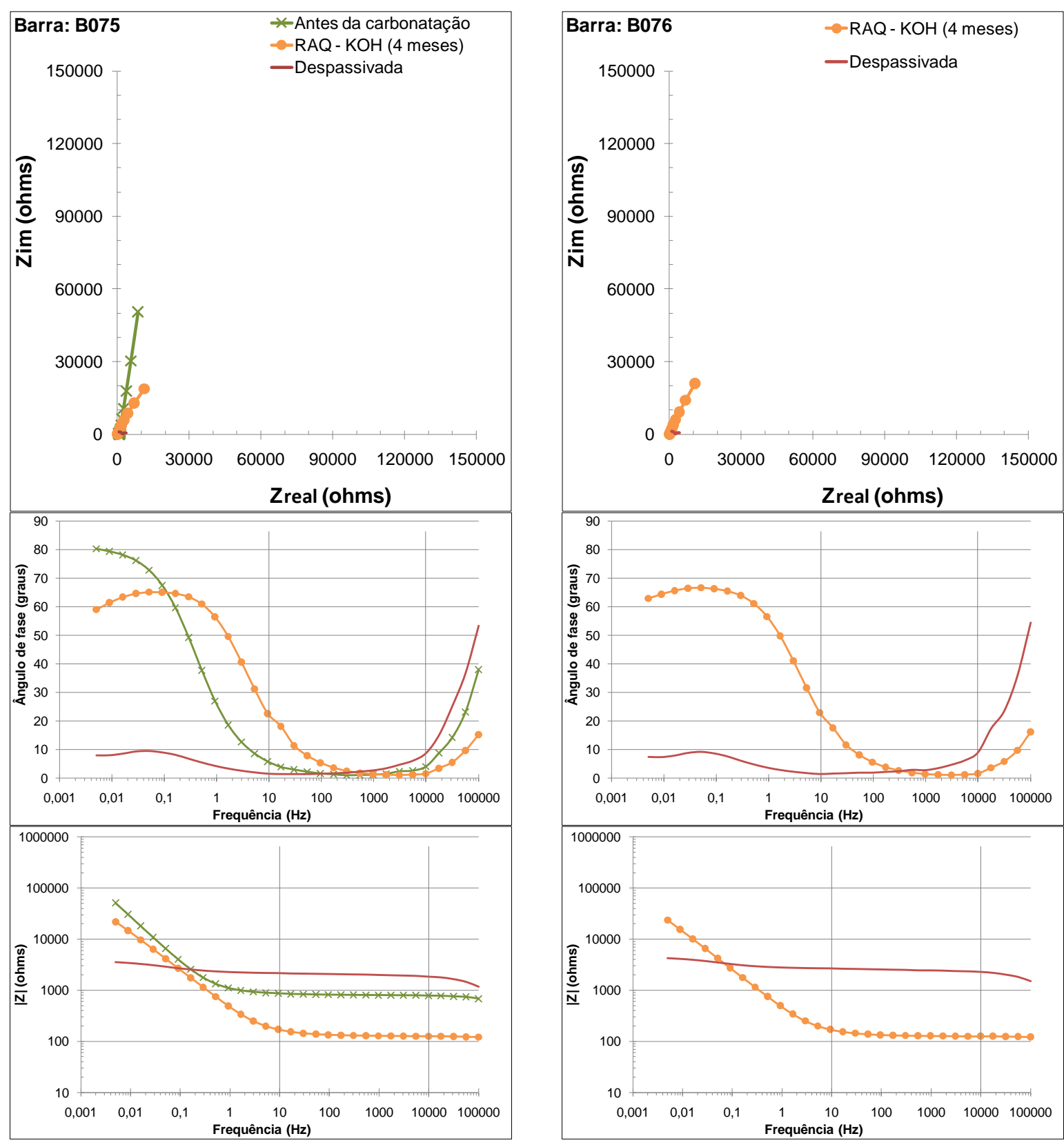
$\underline{\text { RELAÇÃO A/C 0,80 COM CURA DE } 1 \text { DIA }}$

RAQ: com solução alcalina de hidróxido de potássio a 2M (KOH)
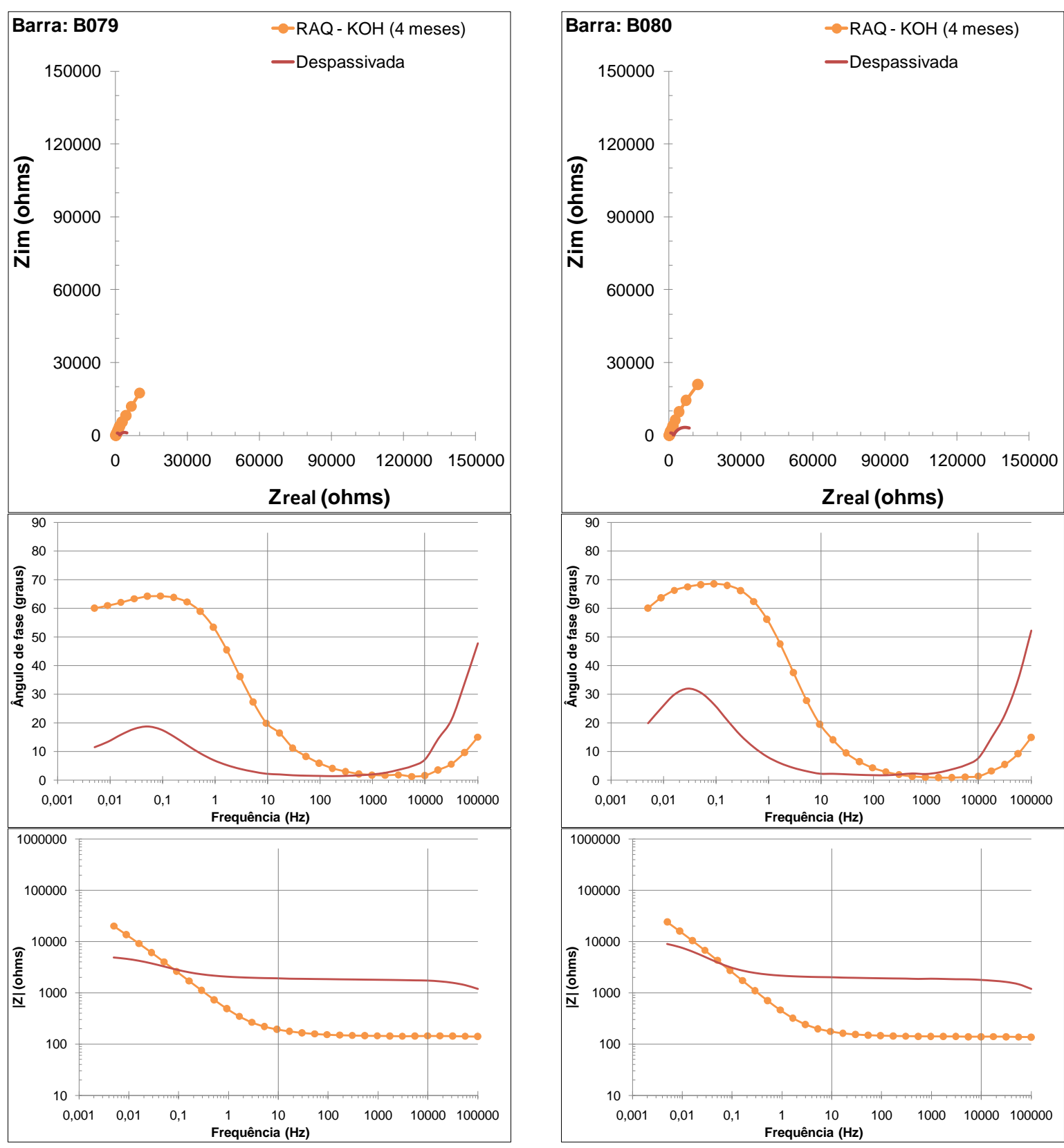
$\underline{\text { RELAÇÃO A/C 0,80 COM CURA DE } 1 \text { DIA }}$

RAQ: com solução alcalina de hidróxido de cálcio saturado $\left(\mathrm{Ca}(\mathrm{OH})_{2}\right)$
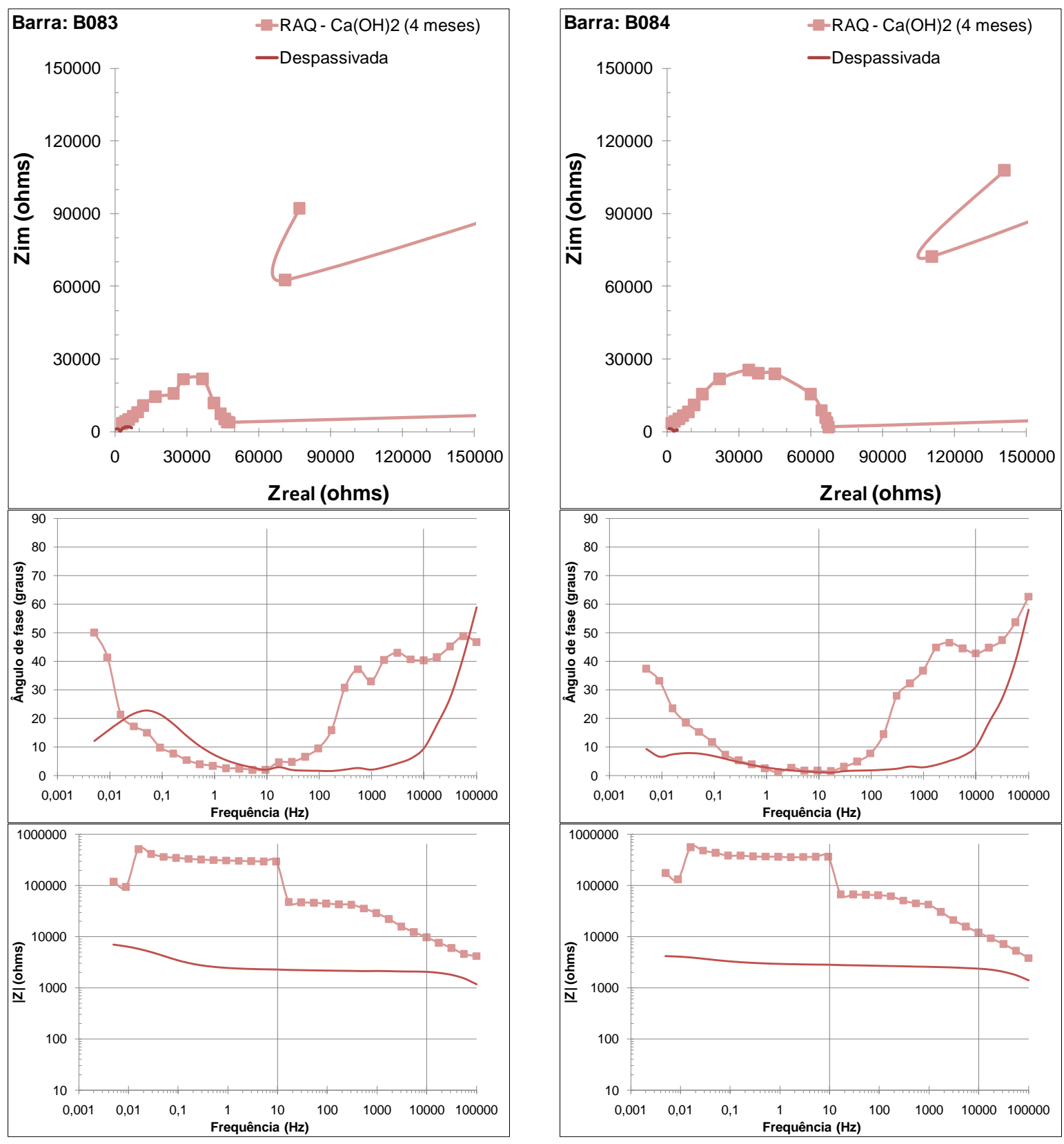
$\underline{\text { RELAÇÃO A/C 0,80 COM CURA DE } 1 \text { DIA }}$

RAQ: com solução alcalina de hidróxido de cálcio saturado $\left(\mathrm{Ca}(\mathrm{OH})_{2}\right)$
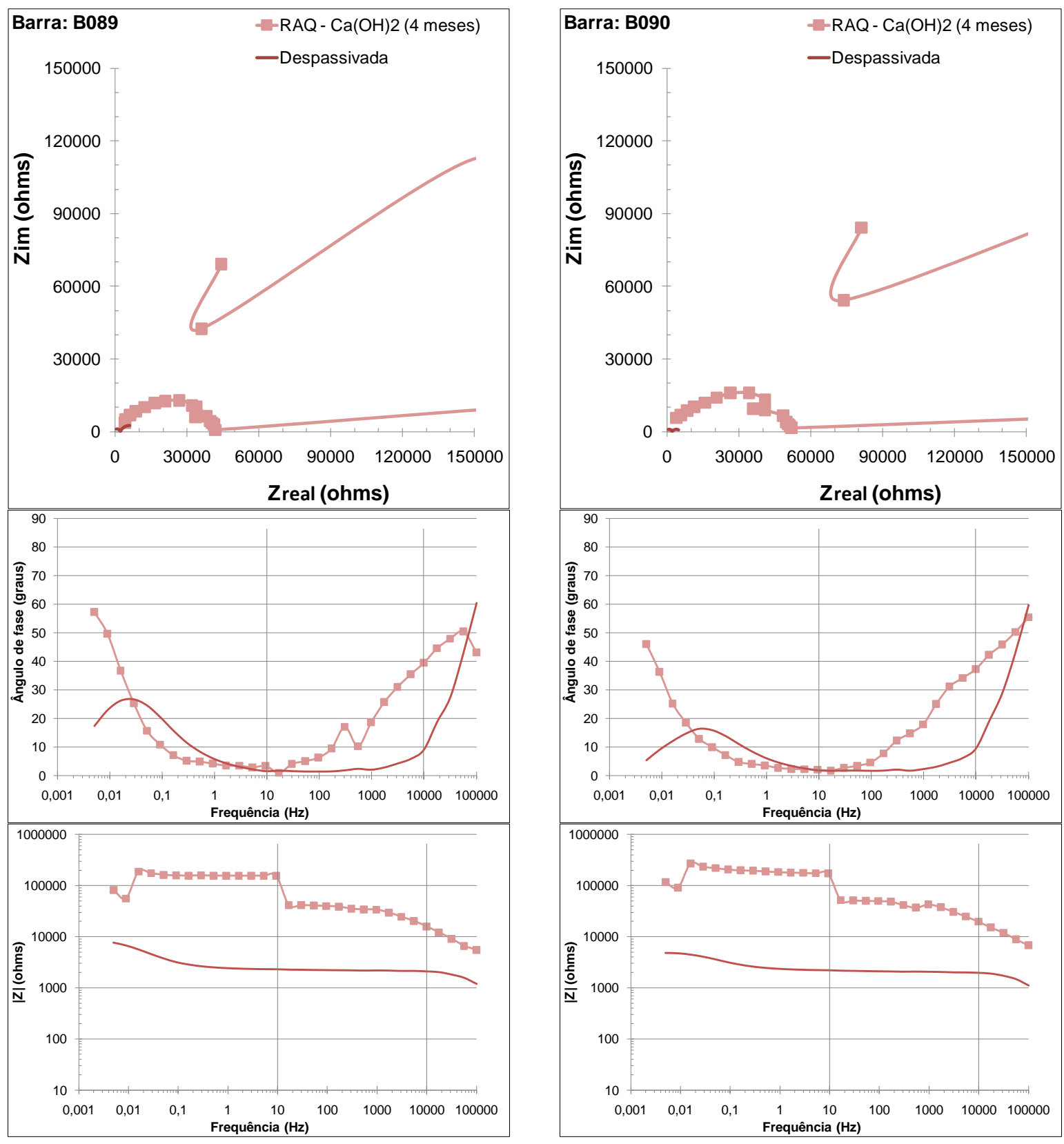
$\underline{\text { RELAÇÃO A/C 0,80 COM CURA DE } 28 \text { DIAS }}$

RAQ: com solução alcalina de carbonato de sódio a $1 \mathrm{M}\left(\mathrm{Na}_{2} \mathrm{CO}_{3}\right)$
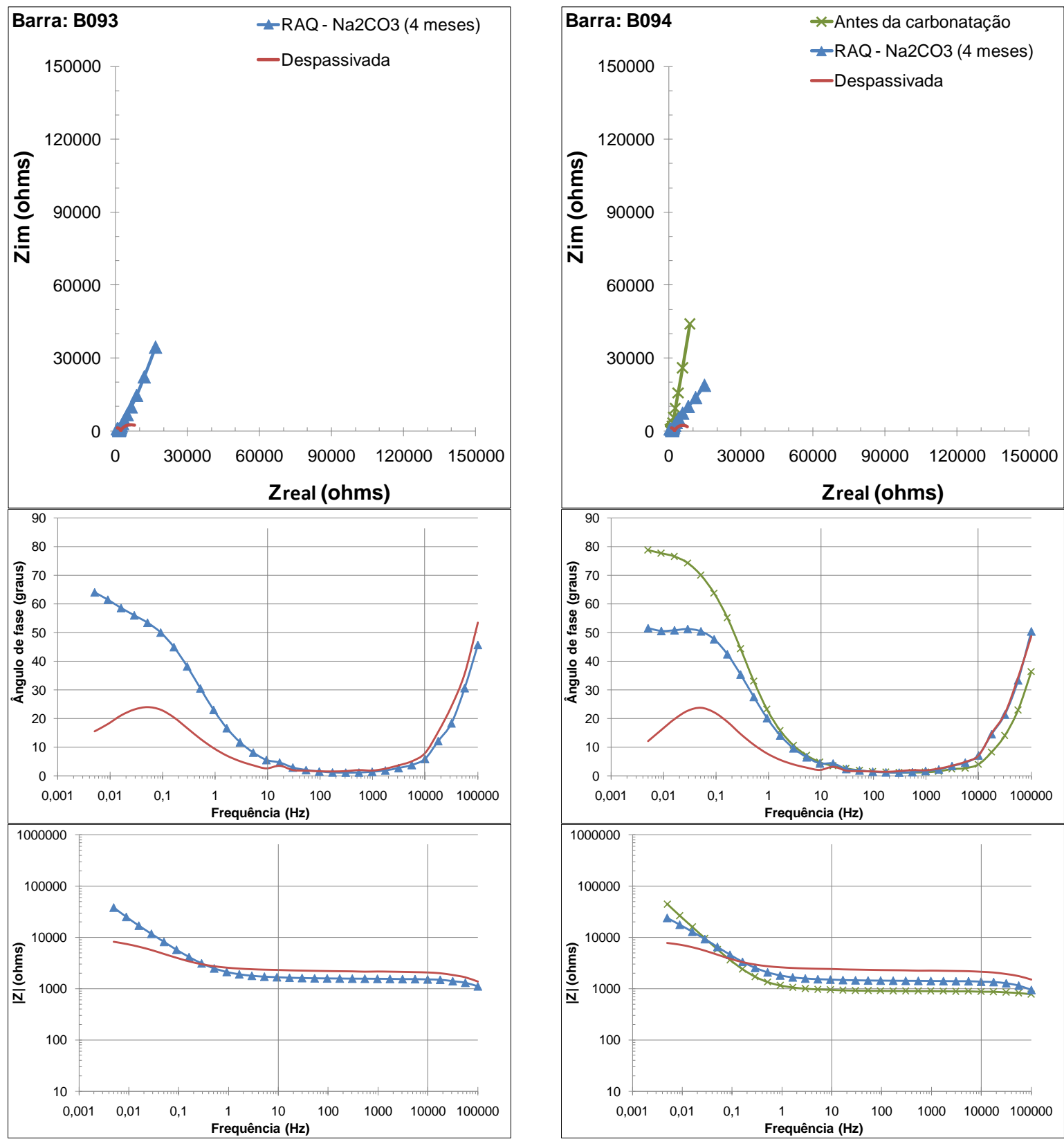
$\underline{\text { RELAC̣ÃO A/C 0,80 COM CURA DE } 28 \text { DIAS }}$

RAQ: com solução alcalina de carbonato de sódio a $1 \mathrm{M}\left(\mathrm{Na}_{2} \mathrm{CO}_{3}\right)$
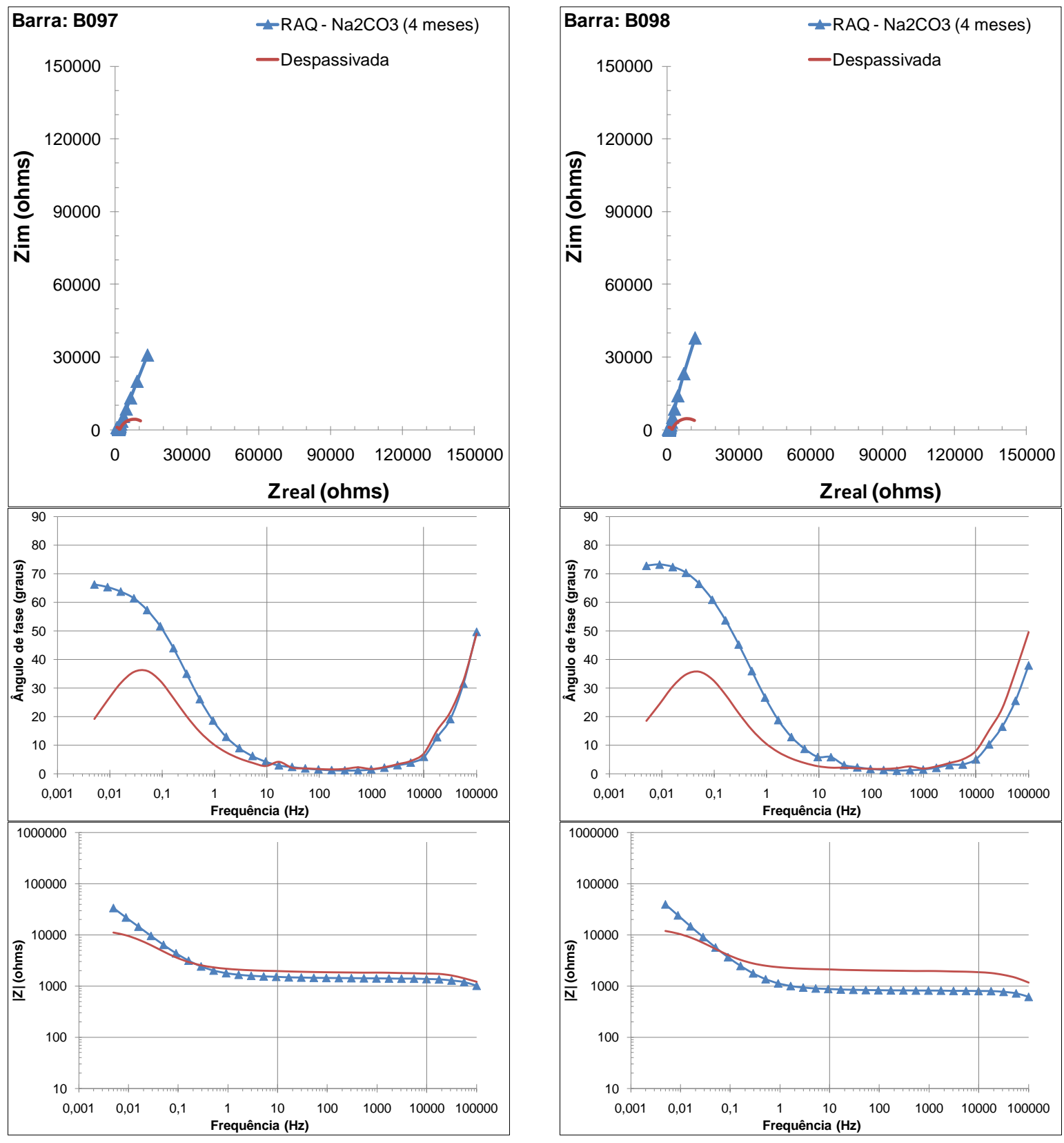
$\underline{\text { RELAÇÃO A/C 0,80 COM CURA DE } 28 \text { DIAS }}$

RAQ: com solução alcalina de hidróxido de potássio a 2M (KOH)
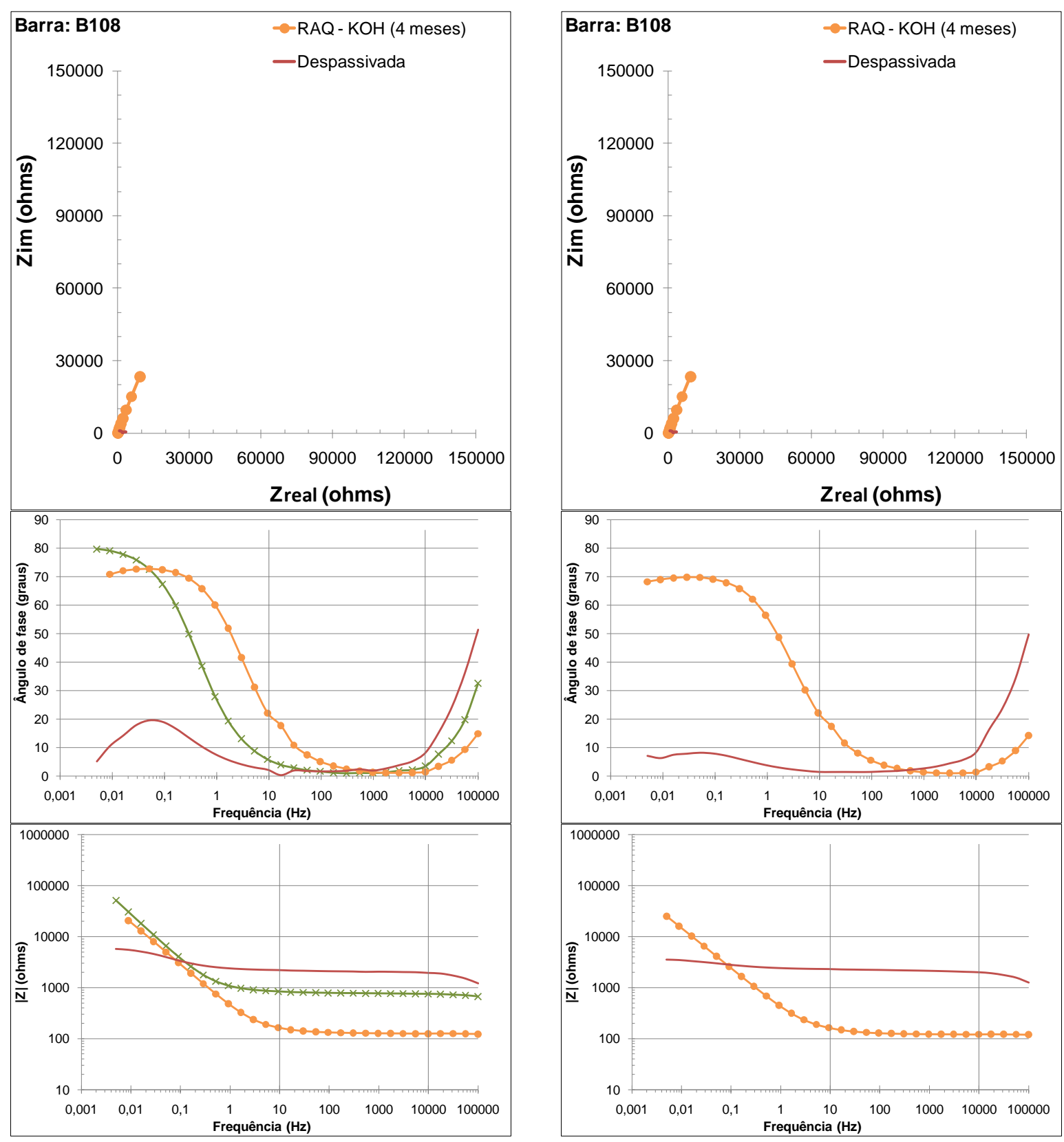
$\underline{\text { RELAČ̃̃O A/C 0,80 COM CURA DE } 28 \text { DIAS }}$

RAQ: com solução alcalina de hidróxido de potássio a 2M (KOH)
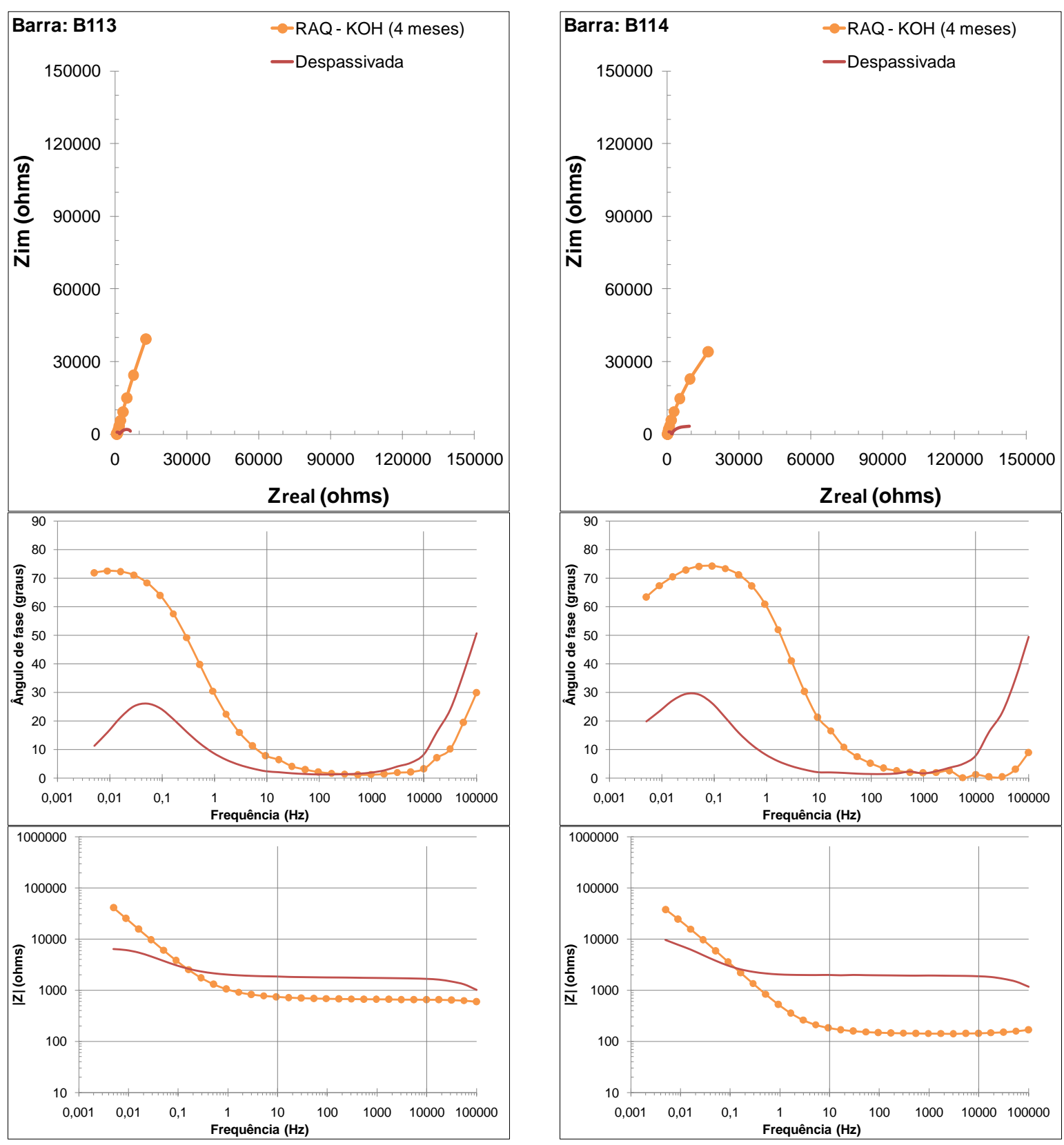


\section{$\underline{\text { RELAÇÃO A/C 0,80 COM CURA DE } 28 \text { DIAS }}$}

RAQ: com solução alcalina de hidróxido de cálcio saturado $\left(\mathrm{Ca}(\mathrm{OH})_{2}\right)$
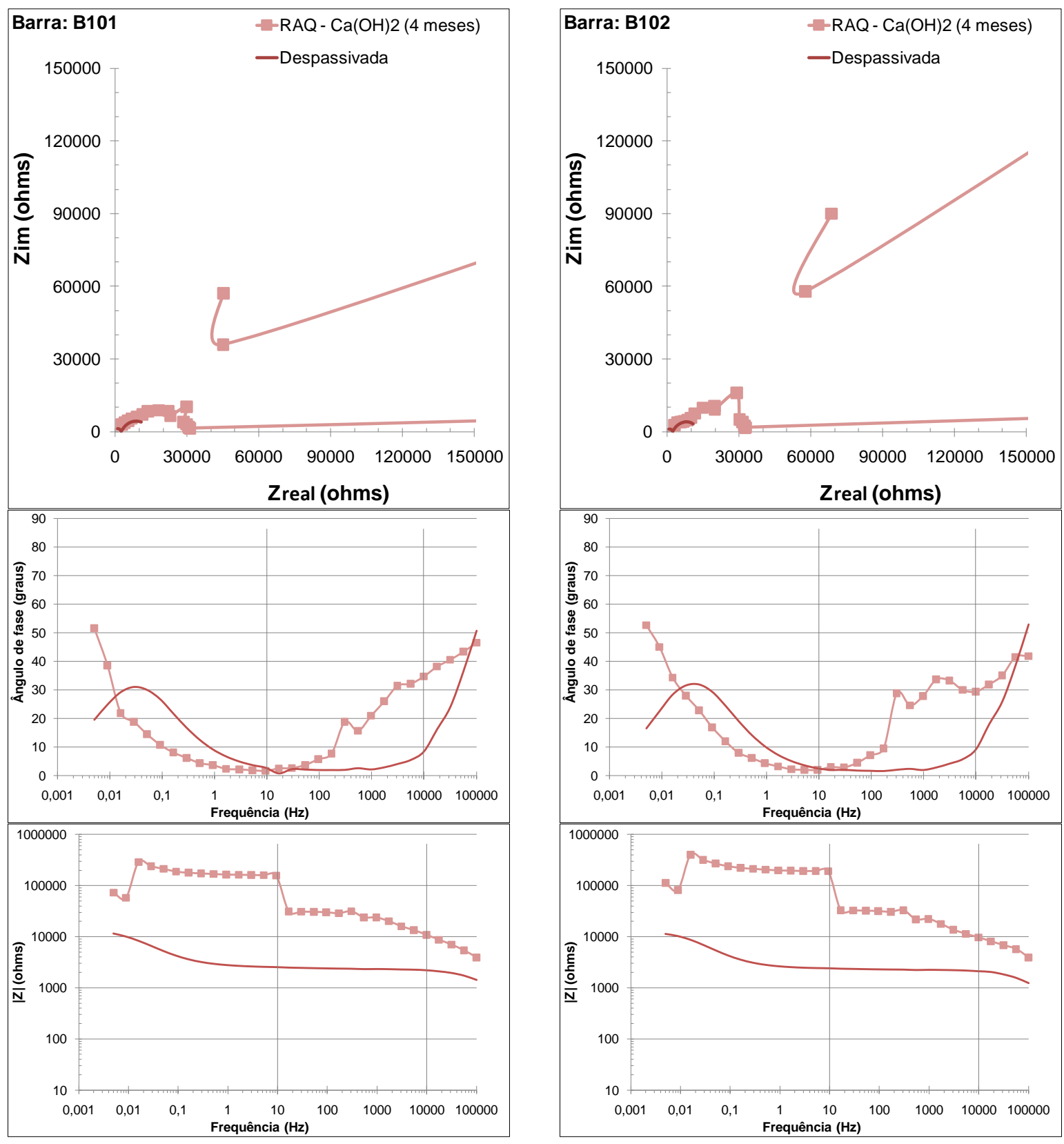


\section{$\underline{\text { RELAÇÃO A/C 0,80 COM CURA DE } 28 \text { DIAS }}$}

RAQ: com solução alcalina de hidróxido de cálcio saturado $\left(\mathrm{Ca}(\mathrm{OH})_{2}\right)$
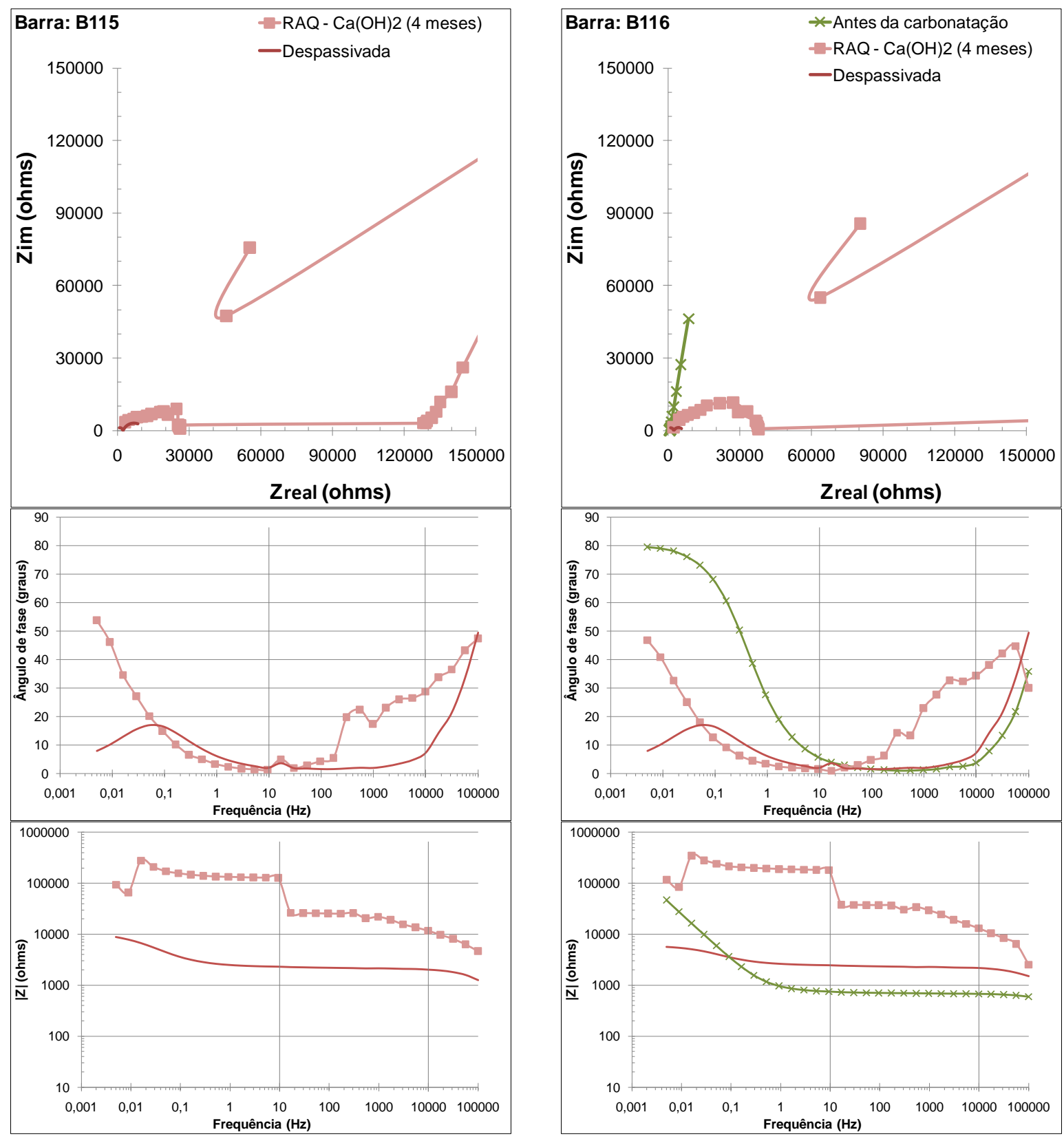
RESULTADOS DE EIE EM CORPOS-DE-PROVA NÃO REALCALINIZADOS

$\underline{\text { RELAÇÃO A/C 0,65 COM CURA DE } 1 \text { DIA }}$
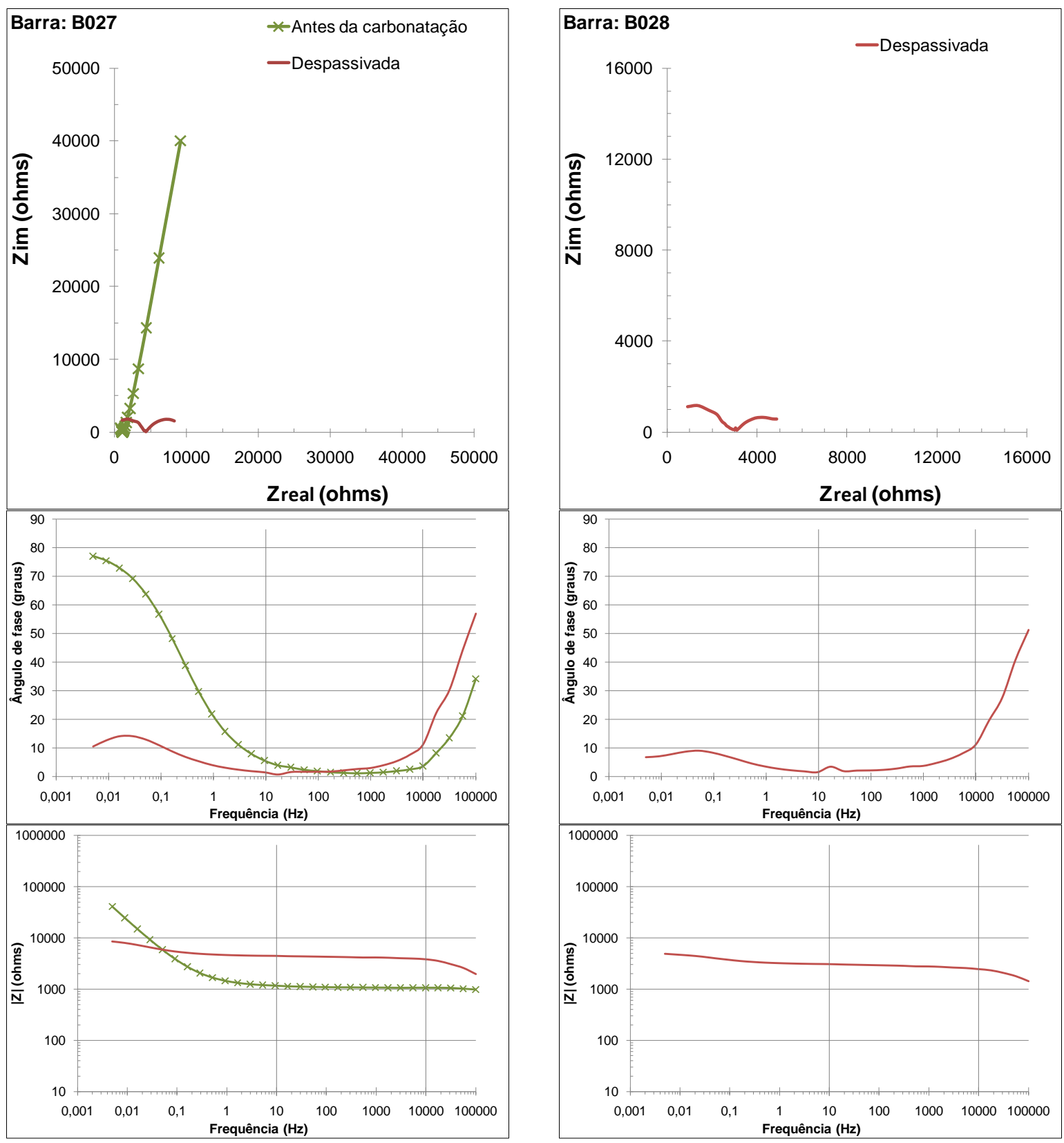


\section{RESULTADOS DE EIE EM CORPOS-DE-PROVA NÃO REALCALINIZADOS}

$\underline{\text { RELAÇÃO A/C 0,65 COM CURA DE } 1 \text { DIA }}$
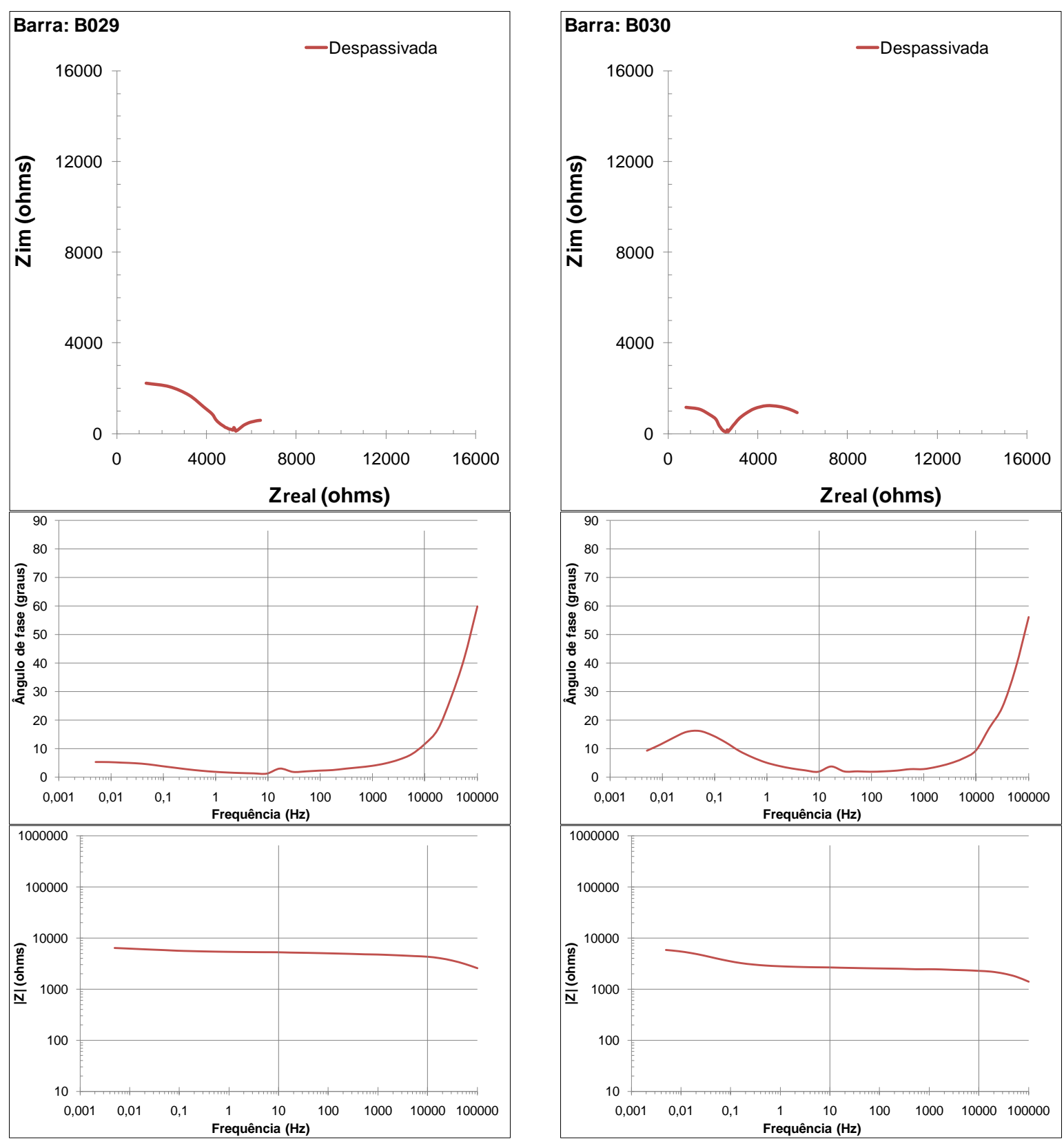
RESULTADOS DE EIE EM CORPOS-DE-PROVA NÃO REALCALINIZADOS

$\underline{\text { RELAÇÃO A/C 0,65 COM CURA DE } 28 \text { DIAS }}$
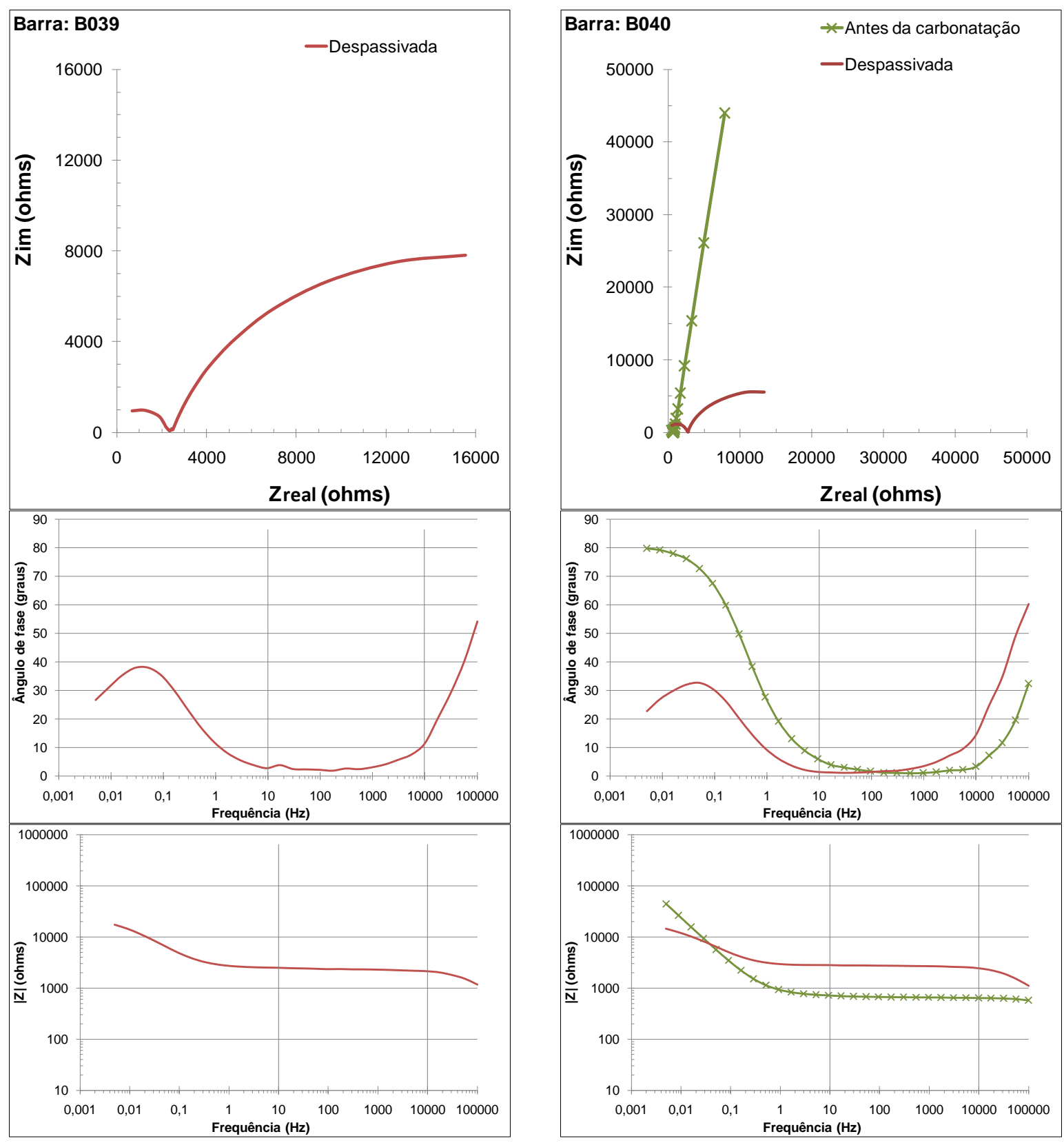


\section{RESULTADOS DE EIE EM CORPOS-DE-PROVA NÃO REALCALINIZADOS}

$\underline{\text { RELAÇÃO A/C 0,65 COM CURA DE } 28 \text { DIAS }}$
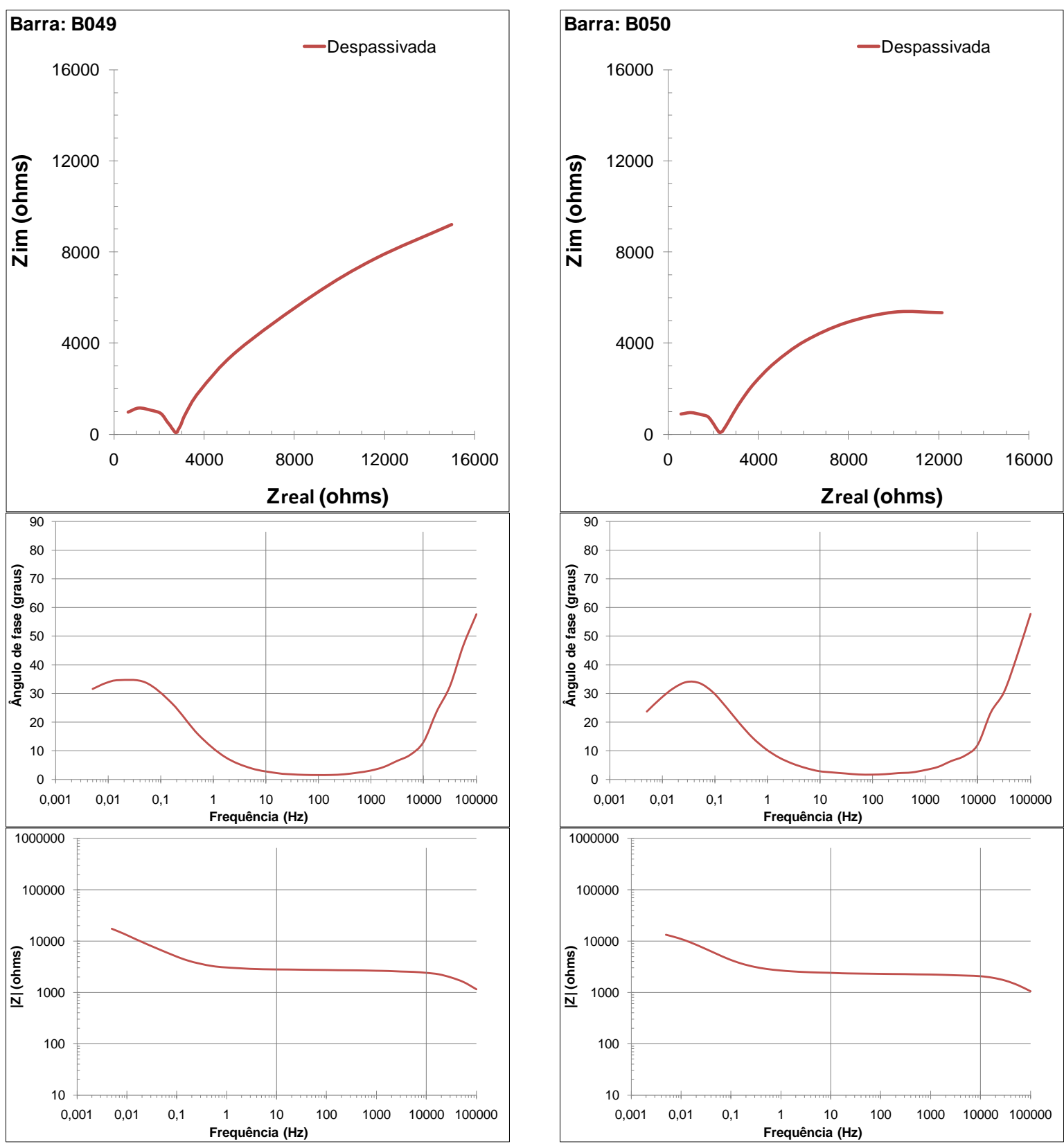


\section{RESULTADOS DE EIE EM CORPOS-DE-PROVA NÃO REALCALINIZADOS}

$\underline{\text { RELAÇÃO A/C 0,80 COM CURA DE } 1 \text { DIA }}$
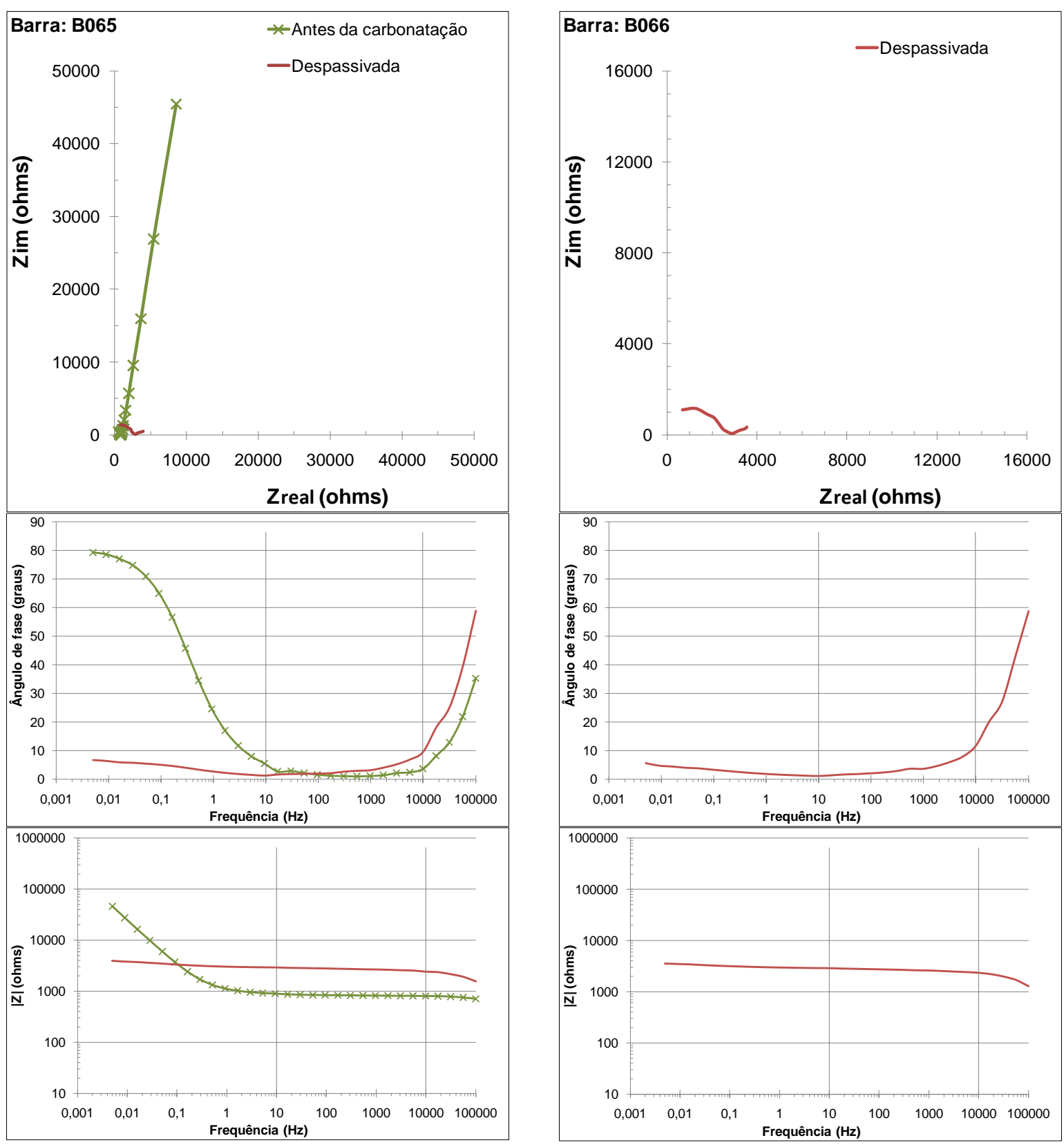


\section{RESULTADOS DE EIE EM CORPOS-DE-PROVA NÃO REALCALINIZADOS}

$\underline{\text { RELAÇÃO A/C 0,80 COM CURA DE } 1 \text { DIA }}$
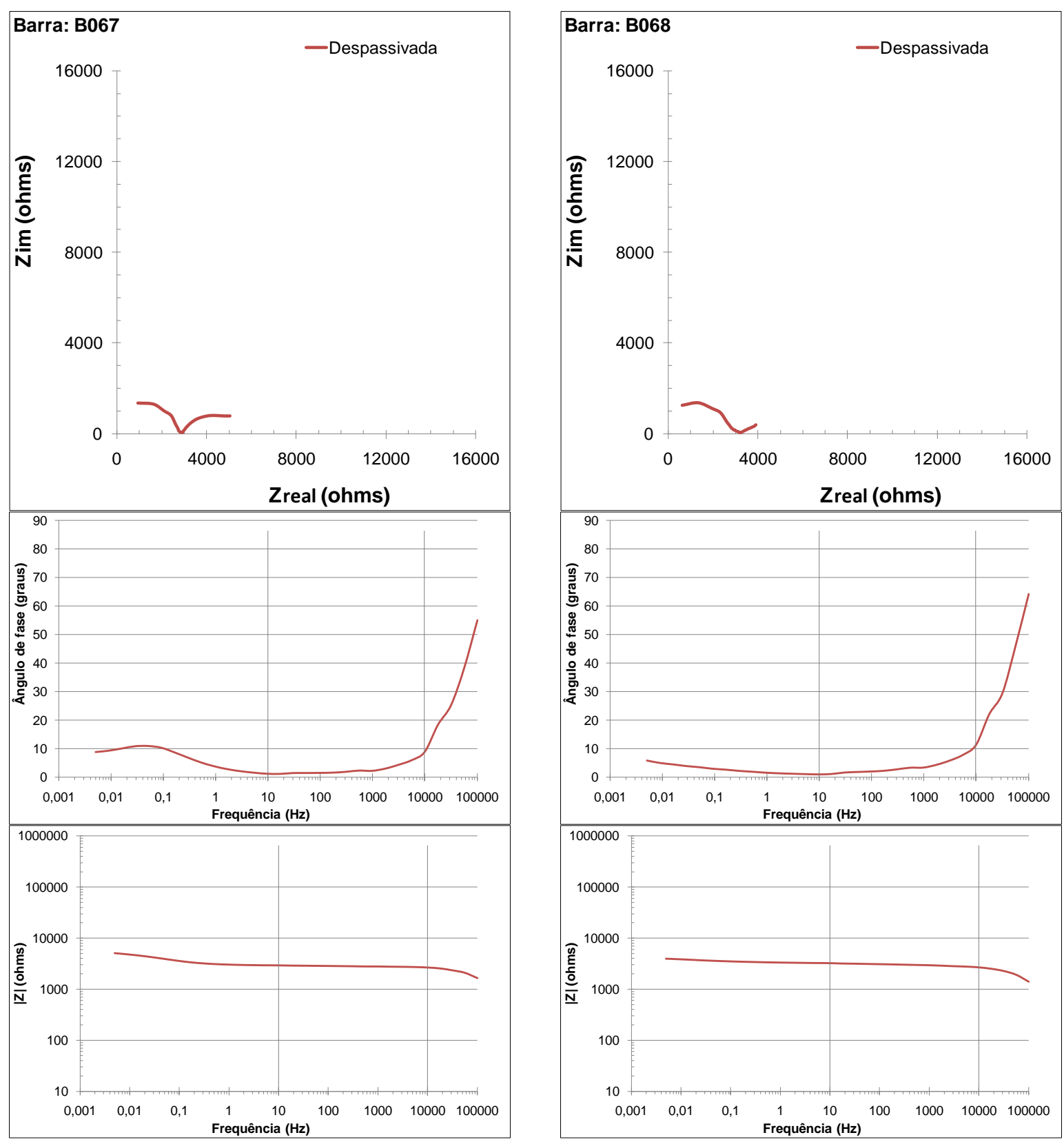
RESULTADOS DE EIE EM CORPOS-DE-PROVA NÃO REALCALINIZADOS

$\underline{\text { RELAÇÃO A/C 0,80 COM CURA DE } 28 \text { DIAS }}$
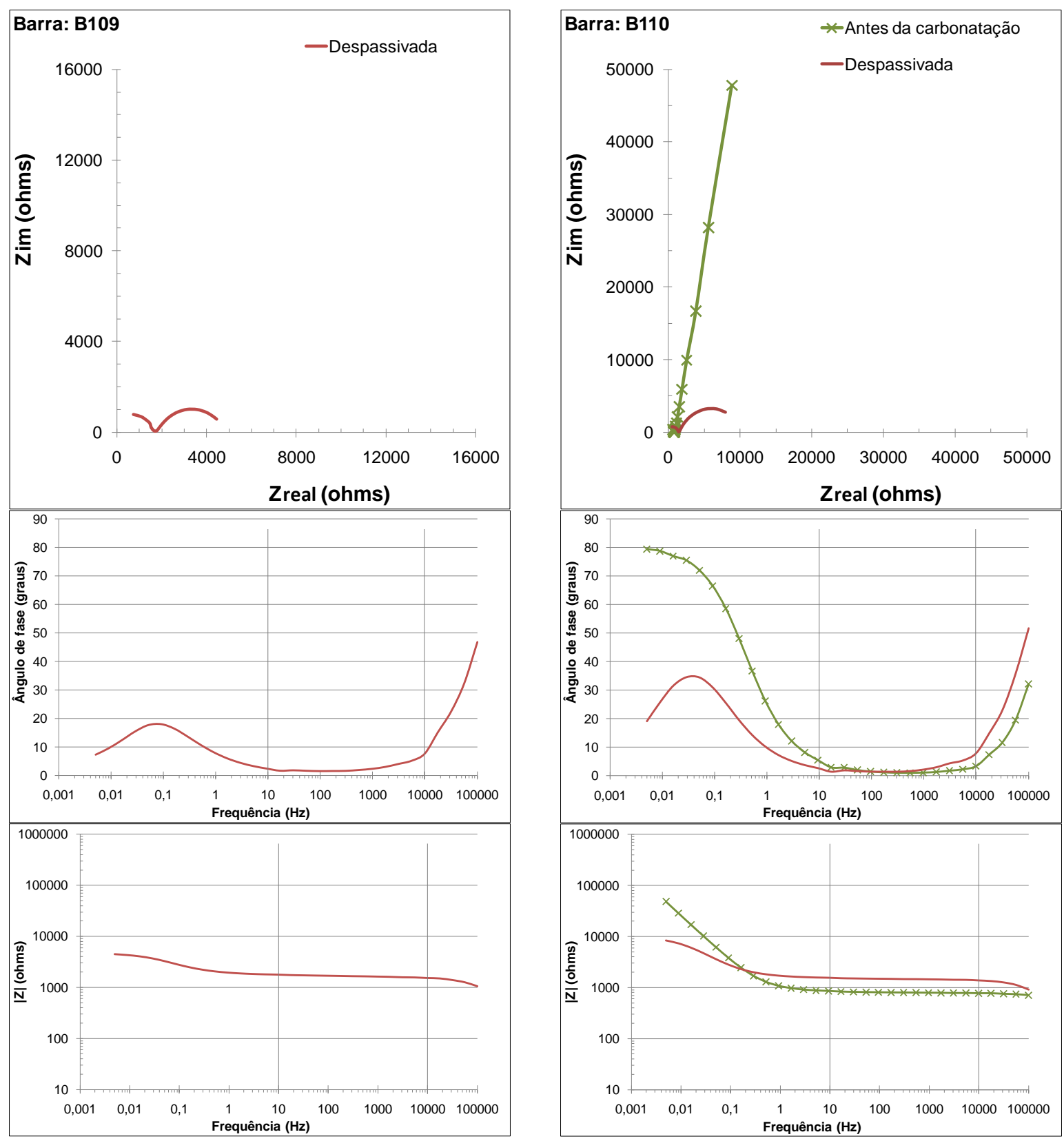
RESULTADOS DE EIE EM CORPOS-DE-PROVA NÃO REALCALINIZADOS

$\underline{\text { RELAÇÃO A/C 0,80 COM CURA DE } 28 \text { DIAS }}$
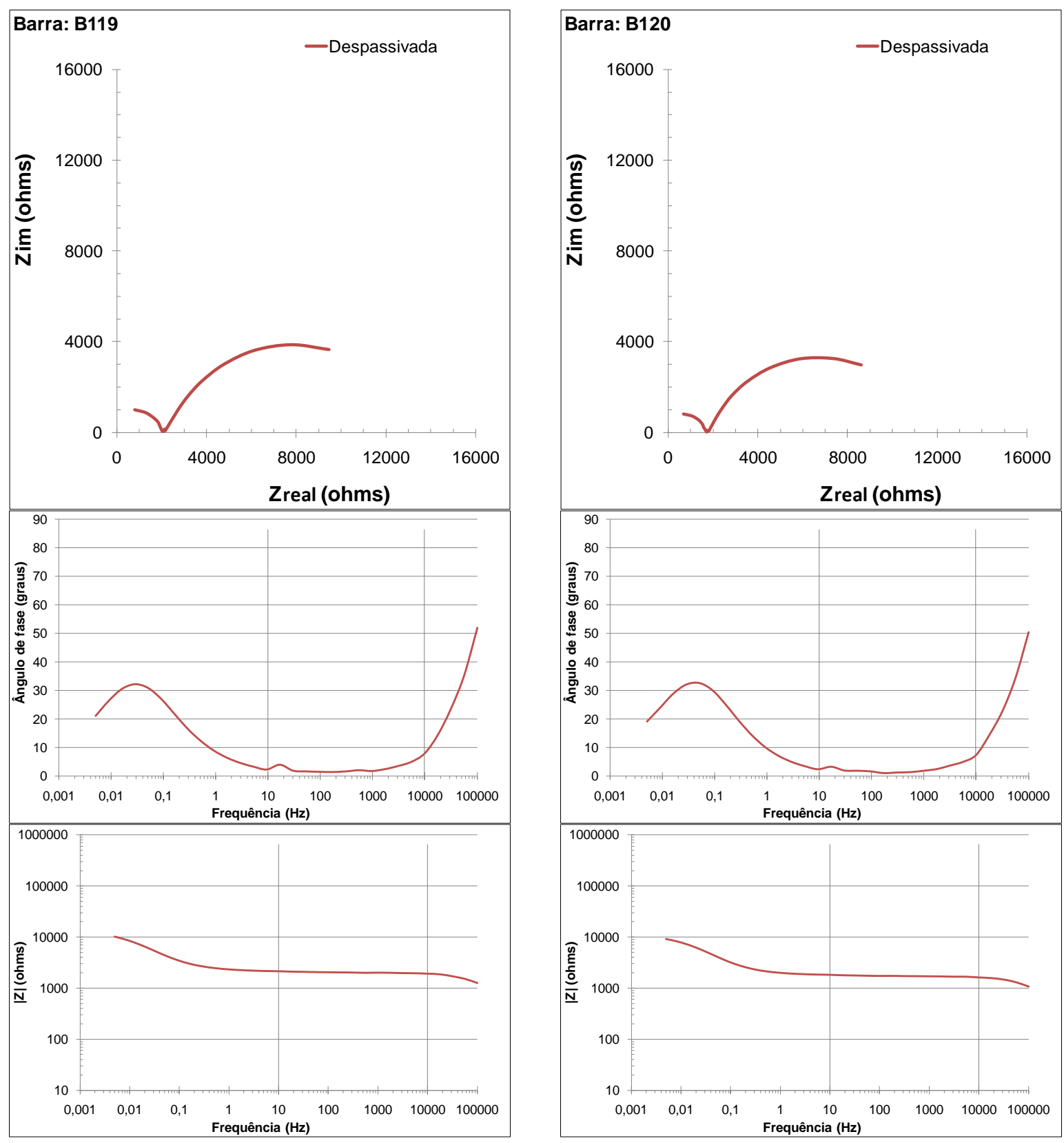